\title{
Redox-neutral S-nitrosation Mediated by a Dicopper Center
}

\author{
Wenjie Tao ${ }^{[a]}$, Curtis E. Moore ${ }^{[a]}$, and Shiyu Zhang*[a] \\ [a] Dr. W. Tao, Dr. C. E. Moore, Prof. Dr. S. Zhang \\ Department of Chemistry \& Biochemistry, The Ohio State University, 100 West $18^{\text {th }}$ Avenue, Columbus, Ohio 43210, United States \\ E-mail: zhang.8941@osu.edu
}

\begin{abstract}
An unprecedented redox-neutral $S$-nitrosation of thiol has been achieved at dicopper $(I, I)$ center. Treatment of dicopper $(I, I)$ complex with excess NO and thiol generates a dicopper (I,I) di-Snitrosothiol complex $\left[\mathrm{Cu}^{\prime} \mathrm{Cu}^{\prime}(\mathrm{RSNO})_{2}\right]^{2+}$ or dicopper (I,I) mono-Snitrosothiol complex $\left[\mathrm{Cu}^{\prime} \mathrm{Cu}^{\prime}(\mathrm{RSNO})\right]^{2+}$, which readily release RSNO in $88-94 \%$ yield. The $S$-nitrosation reaction proceeds through a mixedvalence [Cu"Cul'( $\mu$-O) $(\mu-\mathrm{NO})]^{2+}$ species, which deprotonates RS-H at the basic $\mu-\mathrm{O}$ site and nitrosates the $\mathrm{RS}^{-}$at the $\mu$-NO site. The $\left[\mathrm{Cu}^{\prime \prime} \mathrm{Cu} \mathrm{u}^{\text {III }}(\mu-\mathrm{O})(\mu-\mathrm{NO})\right]^{2+}$ complex is also competent for $\mathrm{O}$-nitrosation of $\mathrm{MeOH}$, which is isoelectronic to thiol. In this case, a rare [Cu"Cul $(\mu-$ $\mathrm{NO})(\mathrm{OMe})]^{2+}$ intermediate has been isolated and fully characterized, suggesting the $S$-nitrosation proceeds through the intermediary of analogous [Cu"Cu" $(\mu-\mathrm{NO})(\mathrm{SR})]^{2+}$ species. The redox- and protonneutral $S$-nitrosation process reported here represents the first functional model of ceruloplasmin in mediating $S$-nitrosation of external thiols, adding further implications for biological copper sites in the interconversion of NO\%RSNO.
\end{abstract}

\section{Introduction}

Nitric oxide is an important signaling molecule that regulates a range of biological processes through $S$-nitrosation (or $S$ nitrosylation) of cysteine residues on proteins. Both excessive and insufficient protein $S$-nitrosation can lead to misfolding that contributes to neurodegenerative diseases, e.g. Alzheimer's disease (AD), ${ }^{[1-3]}$ Parkinson's disease, ${ }^{[1,2,4,5]}$ and Amyotrophic Lateral Sclerosis. ${ }^{[6]}$ Dysregulation of $S$-nitrosothiols (RSNOs) could be a result of altered nitric oxide (NO*) synthase activity or aberrant (de)nitrosation activity of copper proteins. Cu, Zn superoxide dismutase (CuZnSOD) and ceruloplasmin (CP) are closely related to the depletion ${ }^{[6]}$ and accumulation ${ }^{[7,8]}$ of $\mathrm{RSNO}$, respectively.

A central research topic in this paradigm is to understand the chemical mechanism by which RSNOs are formed at metal centers. Covalent attachment of $\mathrm{NO}^{*}$ to thiols (R-SH) requires removal of one electron and one proton (Scheme 1 top). Thus, it is a common belief that $S$-nitrosation requires an external oxidant, e.g. $\mathrm{O}_{2}^{[9,10]}, \mathrm{O}_{2}{ }^{\bullet[11]}, \mathrm{Fe}^{[12-15]}$, and $\mathrm{Cu}^{11}$ [7,16,17] For example, addition of NO to heme proteins, e.g. nitrophorin, hemoglobin, can lead to the formation of $\{\mathrm{FeNO}\}^{6}$ thiolate complex ${ }^{[18-20]}$ and subsequent $S$-nitrosation with simultaneous reduction of $\mathrm{Fe}^{\text {III }}$ to $\mathrm{Fe}^{\text {II }}$ (Scheme 1A). ${ }^{[14,21]} \mathrm{Lu}$ et. al. reported the reductive $S$-nitrosation of an

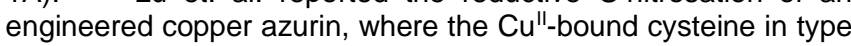
1 copper (T1) site was converted to $S$-nitroso-cysteine residue along with a $\mathrm{Cu}^{\prime}$ center. ${ }^{[22]}$ Simultaneously, Warren et. al. demonstrated reversible $S$-nitrosation of synthetic models of T1 site (Scheme 1B) and structurally characterized the first $S$ nitrosothiol copper adduct $\left[\mathrm{Cu}^{1}\right]\left(\mathrm{K}^{1}-\mathrm{N}(\mathrm{O}) \mathrm{SR}\right) \cdot{ }^{[23]}$ In addition to $\mathrm{T1}$ site, type 2 copper (T2) and binuclear type 3 copper (T3) sites are also critically involved in RSNO formation. Akaike et.al found that RSNO-generation activity at CP was significantly suppressed by various T2 and T3 site inhibitors, such as azide, cyanide, and fluoride.$^{[7]}$ Since CP contains both T1 and T2/T3 sites, it is unclear which copper center is responsible for $S$-nitrosative reactivity of $\mathrm{CP}$. Although T1 site has been shown to directly interact with NO, $[22,23]$ the RSNO-producing activity was observed predominantly with multicopper proteins that contain both $\mathrm{T} 1$ and T2/T3 sites, whereas the efficacy of RSNO formation by T1-only proteins (e.g. azurin) is lower than that of free copper ion $\left(\mathrm{CuSO}_{4}\right) \cdot{ }^{[7]}$ Together, these observations suggest possible roles of binuclear and trinuclear copper centers in the conversion of $\mathrm{NO}^{*}$ and $\mathrm{RSH}$ to RSNO, which has yet to be explored.

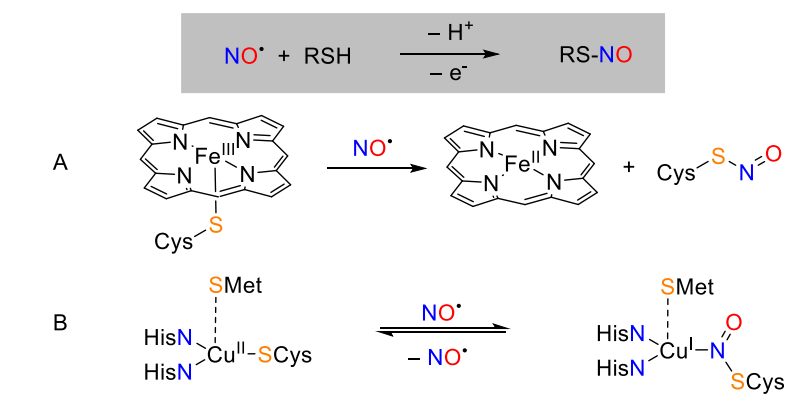

C This work: Redox-neutral S-nitrosation on a dicopper center

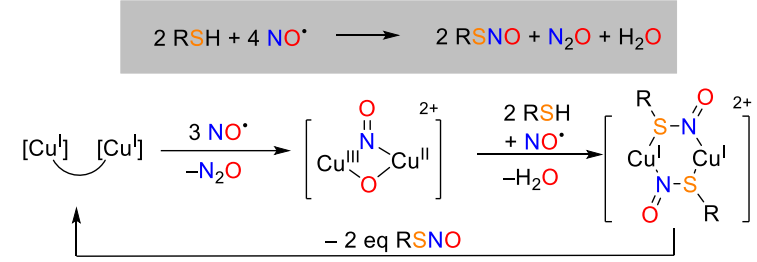

D Examples of binuclear Cu centers in biology

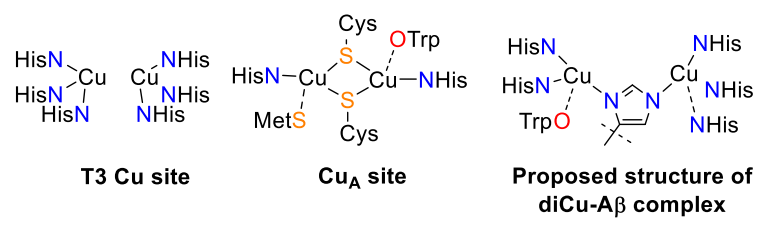

Scheme 1. Reductive S-nitrosation on (A) heme iron and (B) Type 1 copper site. (C) Redox-neutral $S$-nitrosation by a dicopper model complex, which is a functional model of CP mediated RSNO formation. (D) Examples of dinuclear Cu centers in biology. 
Herein, we report a new $S$-nitrosation pathway facilitated by a dicopper complex, which represents the first functional model that mimics CP's ability to generate external $S$-nitrosothiols (Scheme 1C) ${ }^{[7,8]}$ Activation of $\mathrm{NO}^{*}$ at dicopper complex generates a $\left[\mathrm{Cu}_{2}(\mu-\mathrm{O})(\mu-\mathrm{NO})\right]^{2+}$ species, ${ }^{[24]}$ which can nitrosate thiol through (i) deprotonation of $\mathrm{RS}-\mathrm{H}$ at the basic $\mu$-O site, and (ii) reductive coupling of thiolate $\left(\mathrm{RS}^{-}\right)$at the $\mu$-NO site (Scheme 2). Many biological and biomimetic systems show reductive $S$-nitrosation, but now we report a redox-neutral $S$-nitrosation mechanism, where NO provides both the NO motif in RSNO and oxidizing equivalents by coupling of $\mathrm{NO}^{*}$ to $\mathrm{N}_{2} \mathrm{O}$ at dicopper center. Our studies provide implications into how binuclear ${ }^{[25]}$ and multinuclear copper centers (Scheme 1D) could potentially participate in the formation of low mass $S$-nitrosothiols, ${ }^{[26-28]}$ e.g. $S$-nitrosoglutathione, $S$-nitroso-L-cysteine, which serve as oxygen-stable reservoirs of $\mathrm{NO}^{\cdot} \cdot{ }^{[29-31]}$

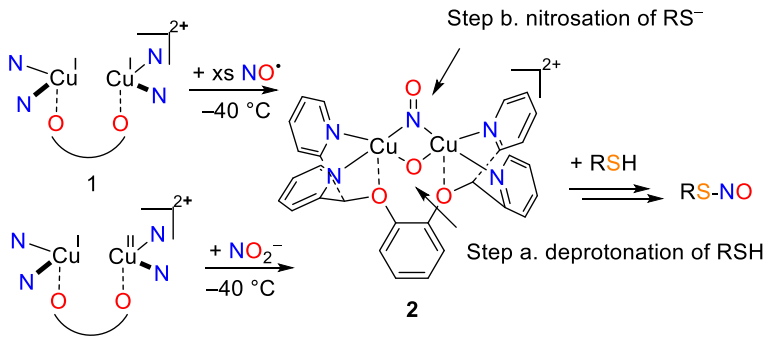

Scheme 2. Proposed S-nitrosation reaction from dicopper(II,III) $\mu$-oxo, $\mu$ nitrosyl complex 2

\section{Results and Discussion}

\section{Reactivity of $\left[\mathrm{LCu}_{2}(\mu-\mathrm{O})(\mu-\mathrm{NO})\right]^{2+}$ with thiols}

Previously, we described that activation of $\mathrm{NO}^{*}$ at dicopper $(\mathrm{I}, \mathrm{I})$ complexes supported by 1,2-bis(di(pyridin-2$\mathrm{yl})$ methoxy)benzene ( $\left.\mathrm{Py}_{4} \mathrm{DMB}, \mathrm{L}\right)$ affords a dicopper (II,III) $\mu$-oxo, $\mu$-nitrosyl complex $\left(\left[\mathrm{LCu}_{2}(\mu-\mathrm{O})(\mu \text {-NO })\right]^{2+} 2\right.$, Scheme 2). ${ }^{[24]}$ Complex 2 can also be accessed from nitrite $\left(\mathrm{NO}_{2}^{-}\right)$via cleavage of the O-NO bond at a dicopper (I,II) synthon. We demonstrated that the $\mu$-oxo motif is active toward oxygen atom transfer and $\mathrm{C}$ $\mathrm{H}$ hydroxylation. The reactivity of $\mu$-NO motif, however, remains unexplored. Since biological and biomimetic copper nitrosyl complexes are known to engage in the interconversion of $S$ nitrosothiol, $\mathrm{NO}^{\circ}$, and nitrite, ${ }^{[23,32]}$ we posit that the $\mu$-NO site in complex $\left(\left[\mathrm{LCu}_{2}(\mu-\mathrm{O})(\mu-\mathrm{NO})\right]^{2+}\right.$ (2) may engage thiol in $S$ nitrosation. The proximal $\mu$-O site can serve as internal base to deprotonate thiols and facilitate S-NO bond formation (Scheme 2). We first investigated the reaction of 2 with a primary thiol, 2phenylethanethiol (PE-SH) as a model substrate for cysteine. Addition of $\mathrm{PE}-\mathrm{SH}$ to complex 2 in the presence of excess $\mathrm{NO} \cdot$ in acetone at $-80^{\circ} \mathrm{C}$ cleanly produces a dark green species 3-PE with strong absorbance at $575 \mathrm{~nm}\left(\varepsilon=2400 \mathrm{M}^{-1} \mathrm{~cm}^{-1}\right)$ and a shoulder at $675 \mathrm{~nm}\left(\varepsilon=1450 \mathrm{M}^{-1} \mathrm{~cm}^{-1}\right)$ (Figure 1, black trace), similar to the characteristic UV-vis features of fully characterized ${ }^{\text {PPr2}} \mathrm{TpCu}^{\prime}\left(\kappa^{1}-\mathrm{N}-\mathrm{Ph}_{3} \mathrm{CSNO}\right)^{[23]}$. Complex 3-PE is highly thermalsensitive, and it decays quickly at temperatures above $-60^{\circ} \mathrm{C}$ Complete generation of 3-PE requires two equivalents of $\mathrm{PE}-\mathrm{SH}$ (Figure S28-29), suggesting 3-PE contains two thiol motifs. Considering the UV-Vis titration evidence, we anticipate that 3-PE might be a dicopper(I,I) di-S-nitrosothiol adduct; therefore, it is denoted as $\left[\mathrm{LCu}^{\prime} \mathrm{Cu}^{\prime}(\mathrm{PE}-\mathrm{SNO})_{2}\right]^{2+}$.
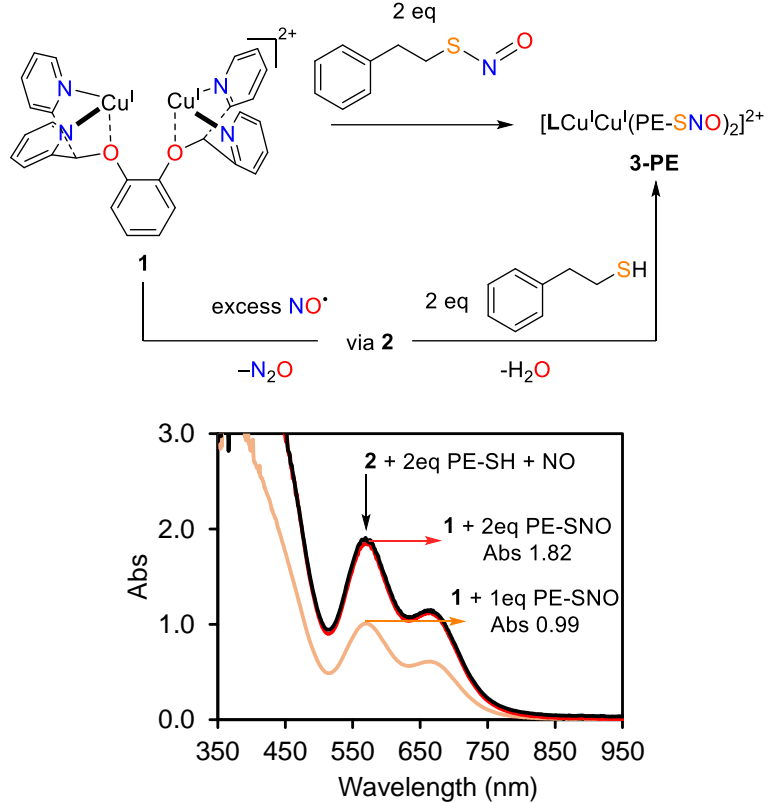

Figure 1. Reaction scheme (top) and corresponding UV-Vis spectra (bottom) of the reaction of 1 with excess $\mathrm{NO}^{\circ}$ and two equivalents of $\mathrm{PE}-\mathrm{SH}$ at $-80{ }^{\circ} \mathrm{C}$ (black). The UV-vis spectrum of reaction of 1 with 1 eq PE-SNO (orange) and 2 eq PE-SNO (red) at $-80^{\circ} \mathrm{C}$

To further explore this hypothesis, we attempted to independently synthesize dicopper(I,I) di-S-nitrosothiol complex 3-PE by treating dicopper(I,I) complex 1 with two equivalents of corresponding RSNO. S-nitroso-2-phenylethanethiol (PE-SNO, Figure 1) can be isolated by treating 2-phenylethanethiol (PE-SH) with $\mathrm{NaNO}_{2}$ or $\mathrm{KNO}_{2}$ under acidic conditions (see supporting information). ${ }^{[33]}$ Addition of two equivalents of PE-SNO to the dicopper (I,I) precursor $\mathbf{1}$ at $-80^{\circ} \mathrm{C}$ affords the same green species 3-PE with UV-vis features at $575\left(\varepsilon=2400 \mathrm{M}^{-1} \mathrm{~cm}^{-1}\right)$ and $675 \mathrm{~nm}\left(\varepsilon=1450 \mathrm{M}^{-1} \mathrm{~cm}^{-1}\right.$, Figure 1, red trace). Complete formation of 3-PE requires two equivalents of PE-SNO with respect to dicopper complex 1 (Figure 1, 1 eq: orange, 2 eq: red) strongly supporting that 3-PE contains two PE-SNO moieties. The UV-Vis spectra generated from $\mathrm{NO}^{\circ}$ and thiol or the direct addition of RSNO are almost identical in terms of peak positions and intensities (Figure 1, black and red traces), suggesting that $\left[\mathrm{LCu}^{\prime} \mathrm{Cu}^{\prime}(\mathrm{PE}-\mathrm{SNO})_{2}\right]^{2+}$ can be prepared in high yields via both routes.

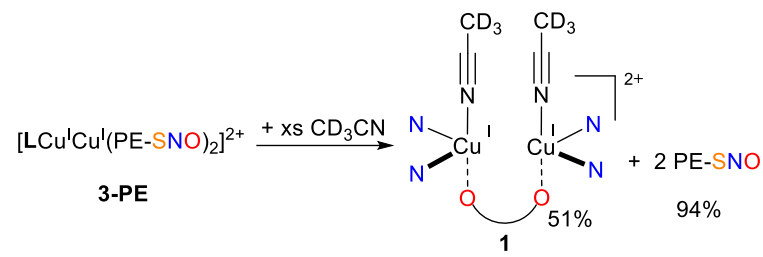

Scheme 3. Displace the bound S-nitroso-2-phenylethanethiol from $\mathrm{Cu}^{\prime}$ by excess amount of $\mathrm{CD}_{3} \mathrm{CN}$.

To further confirm the identity of 3-PE as a dicopper di-Snitrosothiol adduct, we attempted to displace the $S$-nitrosothio with a ligand that can tightly bind the dicopper(I,I) center. Addition of excess acetonitrile- $d_{3}$ to a solution of 3-PE generated from the reaction of 2 and two equivalents of PE-SH in acetone- $d_{6}$ at -80 
${ }^{\circ} \mathrm{C}$ causes a color change from dark green to light yellow with an absorbance at $550 \mathrm{~nm}$ (Figure S39-40), which is characteristic for $\mathrm{PE}-\mathrm{SNO} .{ }^{1} \mathrm{H}$ NMR analysis of the reaction mixture suggests that two equivalents of PE-SNO are produced in $94 \%$ yield. Formation of the dicopper $(\mathrm{I}, \mathrm{I})$ acetonitrile complex 1 was also observed in $51 \%$ yield (Scheme 3 ). This reaction is significant because the combined consequence of Scheme 2 and Scheme 3 represents a new way to covalently attach NO to thiol in redox-neutral and proton-neutral fashion, contrasting to traditional mono- $\mathrm{Cu}^{[23,34]}$ or mono- $\mathrm{Fe}^{[14,35]}$-mediated reductive nitrosation pathways.

Encouraged by the reactivity of 2 with primary thiol PE-SH, we further examined the reaction of $\mathbf{2}$ with a cysteine analog, $\mathrm{N}$ acetyl-L-cysteine methyl ester (Cys-SH). The putative dicopper(I,I) S-nitrosothiol complex 3-Cys has a UV-Vis absorbance at $570 \mathrm{~nm}\left(\varepsilon=2500 \mathrm{M}^{-1} \mathrm{~cm}^{-1}\right)$ and $670 \mathrm{~nm}(\varepsilon=2200$ $\mathrm{M}^{-1} \mathrm{~cm}^{-1}$, Figure 2, blue trace). 3-Cys can be prepared via the treatment of 1 with excess NO followed by two equivalents of Cys-SH (Figure 2). The formation of Cys-SNO from this reaction is determined by addition of excess acetonitrile- $d_{3}$ to displace the copper-bound Cys-SNO. Quantitative ${ }^{1} \mathrm{H}$ NMR analysis of the reaction mixture suggests that two equivalents of Cys-SNO are produced in $88 \%$ yield. Formation of the dicopper $(\mathrm{I}, \mathrm{I})$ acetonitrile complex was also observed in $34 \%$ yield. Alternatively, 3-Cys can be synthesized from the treatment of 1 with Cys-SNO (Figure 2 red trace). Interestingly, the plot of UV-Vis absorbance vs. equivalent of Cys-SNO used exhibits a maximum at a 1:1 ratio of 1: Cys-SNO (Figure S43-44), suggesting that 3-Cys is a dicopper mono-S-nitrosothiol complex $\left[\mathrm{LCu}^{\prime} \mathrm{Cu}^{\prime}(\mathrm{Cys}-\mathrm{SNO})\right]^{2+}$. Only one equivalent of Cys-SNO can bind to dicopper(I,I) 1 perhaps because the intramolecular amide (NHAc) and ester $\left(\mathrm{CO}_{2} \mathrm{Me}\right)$ functional groups on Cys compete with RSNO coordination.

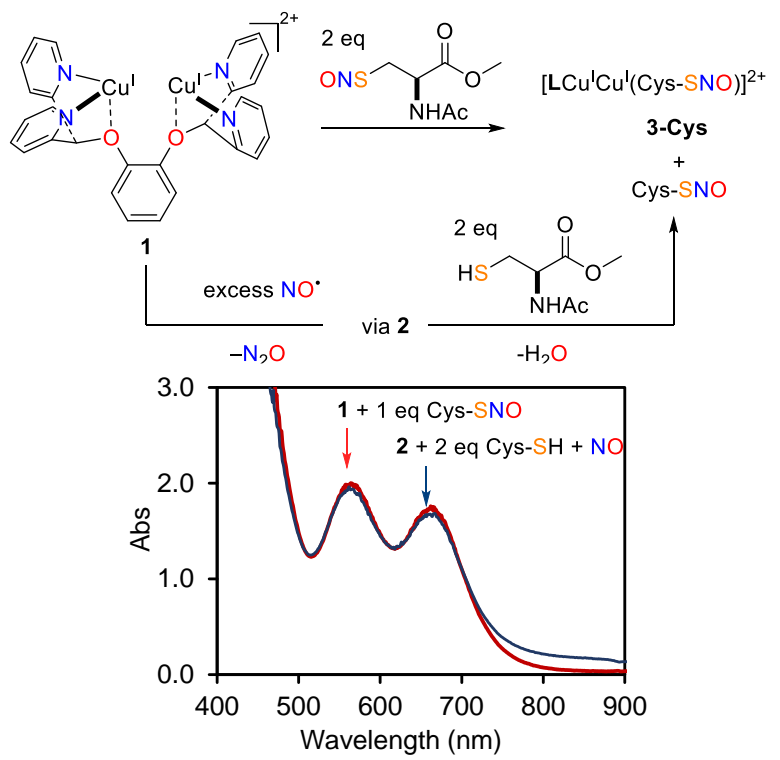

Figure 2. Reaction scheme (top) and corresponding in-situ UV-Vis spectra of the synthesis of 3-Cys. 3-Cys can be generated from either treatment of $\mathbf{1}$ with $\mathrm{NO} \cdot$ and Cys-SH (blue trace, $-80^{\circ} \mathrm{C}$ ) or addition of 2 equivalents of Cys-SNO to complex 1 (red trace, $-80^{\circ} \mathrm{C}$ ).

\section{Characterization of $\left[\mathrm{LCu}_{2}{ }_{2}(\mathrm{PE}-\mathrm{SNO})_{2}\right]^{2+}$ adduct 3-PE.}

Our effort in structurally characterizing 3-PE was hampered by its thermal sensitivity. We found that 3-PE decomposes to mono-copper(II) complex [ $\left.\mathrm{LCu}^{\prime \prime}\right] \mathrm{PF}_{6}$ even at $-60^{\circ} \mathrm{C}$ over a few days, which is presumably due to the loss of $\mathrm{NO}^{\circ}$ along with the expulsion of copper(II) thiolate clusters (Scheme 4). ${ }^{[36]}$

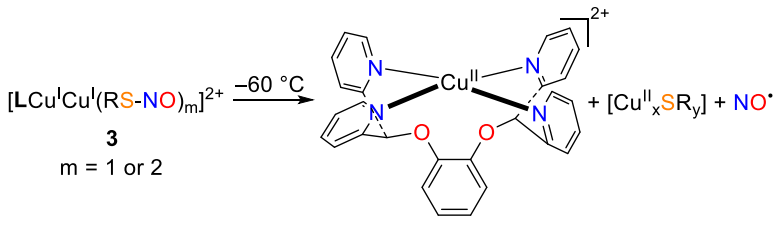

Scheme 4. The decomposition pathway of dicopper(I,I) S-nitrosothiol intermediate above $-60{ }^{\circ} \mathrm{C}$

To determine the binding mode of PE-SNO at 3-PE, the reaction of two equivalents of $\mathrm{PE}-\mathrm{S}^{15} \mathrm{NO}$ with 1 was monitored with ${ }^{15} \mathrm{~N}$ NMR. At room temperature, the ${ }^{15} \mathrm{~N} N M R$ spectrum of PE$\mathrm{S}^{15} \mathrm{NO}$ displays a broad resonance at $771 \mathrm{ppm}$ vs. $\mathrm{NH}_{3}$. Upon cooling to $-80^{\circ} \mathrm{C}$, the syn and anti configurations of PE-SNO can be resolved as two sharp peaks at 830 and $758 \mathrm{ppm}$ (vs. $\mathrm{NH}_{3}$ ). Addition of 2.4 equivalents of $\mathrm{PE}-\mathrm{S}^{15} \mathrm{NO}$ to 1 at $-80^{\circ} \mathrm{C}$ leads to two new resonances at 535 and $521 \mathrm{ppm}\left(\mathrm{vs} . \mathrm{NH}_{3}\right.$ ) (Figure $3 \mathrm{~A}$ ), suggesting that $\mathrm{PE}-\mathrm{SNO}$ might coordinate to the dicopper center in two different binding modes. The ${ }^{15} \mathrm{~N}$ chemical shifts of 3-PE are very similar to previously reported ${ }^{\mathrm{Mes}} \mathrm{TpCu}(\mathrm{I})\left(\kappa^{1}-\mathrm{N}(\mathrm{O}) \mathrm{SCPh}_{3}\right)$ $\left(560 \mathrm{ppm}\right.$ vs. $\left.\mathrm{NH}_{3}\right){ }^{[23]}$ which strongly suggests that both the ${ }^{15} \mathrm{~N}$ atoms coordinate directly to the $\mathrm{Cu}(\mathrm{I})$ center.

A
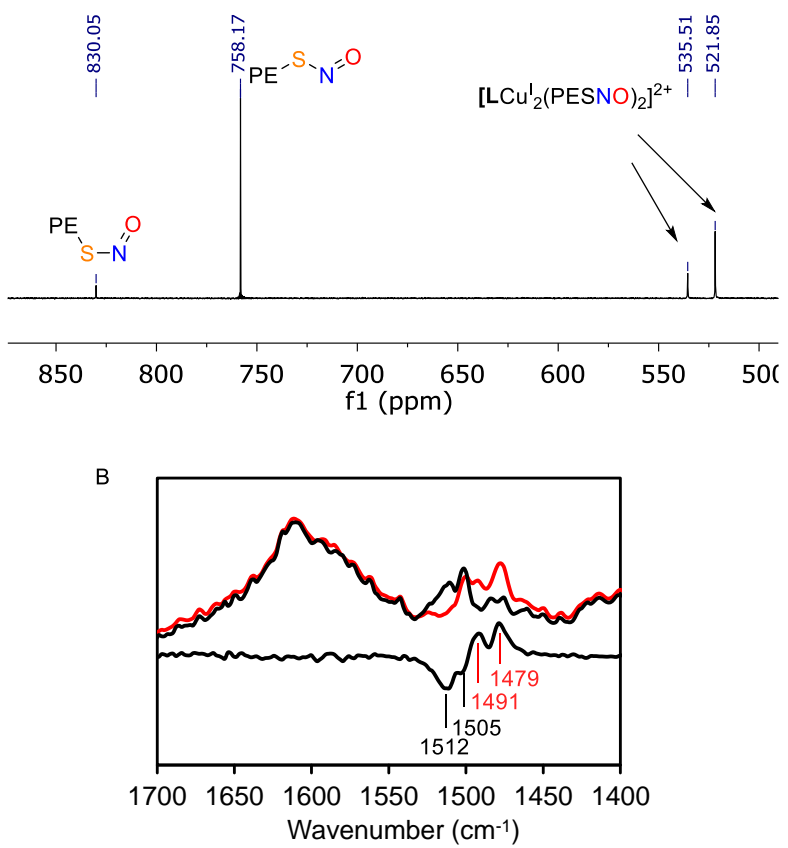

Figure 3. (A) ${ }^{15} \mathrm{~N}$ NMR (acetone- $d_{6},-80^{\circ} \mathrm{C}$ ) spectrum of the reaction of 1 with 2.4 eq of PE-S ${ }^{15} \mathrm{NO}$. (B) In-situ IR spectra for the formation of $3-\mathrm{PE}-{ }^{-14} \mathrm{~N}$ and 3 PE-15N $\left(-78^{\circ} \mathrm{C}, 20 \mathrm{mM}\left[\mathrm{Cu}_{2}\right]\right.$, THF- $\left.d_{8}\right)$ generated from the reaction of 1 with two equivalents of $\mathrm{PE}-\mathrm{S}^{14} \mathrm{NO}$ (dark blue) or $\mathrm{PE}-\mathrm{S}^{15} \mathrm{NO}$ (red). The difference spectrum of ${ }^{14} \mathrm{~N}$ and ${ }^{15} \mathrm{~N}$ sample is shown in black.

The reaction of $\mathbf{1}$ and PE-SNO is further investigated by solution IR spectroscopy. Two new ${ }^{15} \mathrm{~N}$-label-sensitive bands at $1512(-21)$ and $1505(-26) \mathrm{cm}^{-1}$ grow in when 1 is treated with two equivalents of PE-SNO in THF- $d_{8}$ at $-78{ }^{\circ} \mathrm{C}$ (Figure 3B). These vibration frequencies are much higher than the $\mathrm{N}=\mathrm{O}$ stretch observed for the fully-characterized ${ }^{\mathrm{Mes}} \mathrm{TpCu}(\mathrm{I})\left(\kappa^{1}-\mathrm{N}(\mathrm{O}) \mathrm{SCPh}_{3}\right)$ complex $\left(1424 \mathrm{~cm}^{-1}\right){ }^{[23]}$ The presence of two different $\mathrm{N}=\mathrm{O}$ stretches can be explained by the symmetric and unsymmetric 
coupling of two PE-SNO units. It is well-known that coordination of RSNO to metal center or Lewis acid via S, O, N atoms can alter the strength of $\mathrm{N}=\mathrm{O}$ and $\mathrm{S}-\mathrm{N}$ bond. ${ }^{[23,37-40]}$ While $k^{1}-\mathrm{N}$ coordination of $S$-nitrosothiols weakens the $\mathrm{N}=\mathrm{O}$ bond and strengthens the $\mathrm{N}$ $S$ bond, $k^{1}-S$ coordination has the opposite effects (Scheme $5 \mathrm{~A}$ ). Therefore, the higher $\mathrm{N}=\mathrm{O}$ stretches of dicopper(I,I)-bound PESNO (1512 and $\left.1505 \mathrm{~cm}^{-1}\right)$ in comparison to free PE-SNO (1495 $\mathrm{cm}^{-1}$, Figure S64-65) strongly suggests that the $S$ atoms of PE$\mathrm{SNO}$ also coordinate/interact with the $\mathrm{Cu}(\mathrm{I})$ center.

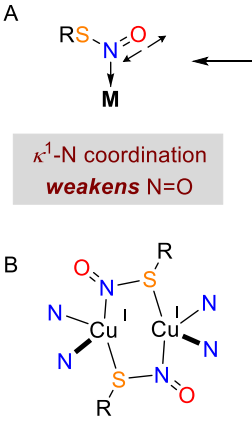

$\mathrm{C}_{2}$-symmetric $\mu-\kappa^{1}-\mathrm{N}: \kappa^{1}-\mathrm{S}$

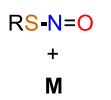

M
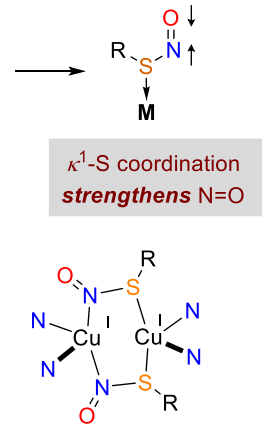

$\mathrm{C}_{\mathrm{S}}$-symmetric $\mu-\kappa^{1}-\mathrm{N}: \kappa^{1}-\mathrm{S}$
Scheme 5. The $\mathrm{N}=\mathrm{O}$ stretches in different binding bodes of $S$-nitrosothiol bound to transition metal or Lewis acid and the most likely binding mode of 3-PE.

Taken together, IR and ${ }^{15} \mathrm{~N}$ NMR spectroscopic studies indicate that the binding mode of PE-SNO at the dicopper center is best assigned as $\mu^{-1} \kappa^{1}-\mathrm{N}: \kappa^{1}-\mathrm{S}$ in THF and acetone. The two PESNO motifs could be arranged $\mathrm{C}_{2}$-symmetry or $\mathrm{C}_{\mathrm{s}}$-symmetry (Scheme $5 \mathrm{~B}$ ), which gives rise to the two distinct ${ }^{15} \mathrm{~N}$ NMR peaks. It is important to note that there are many possible binding modes of PE-SNO at the dicopper center $\left(C_{2}\right.$-symmetry or $C_{s}$-symmetry, syn or anti, O, S, N-bound), and the interactions of RSNO and $\mathrm{Cu}$ are expected to be sensitive to the solvent environment, as the coordination of solvent molecules may lead to different binding modes through $\mathrm{S}, \mathrm{O}$, and $\mathrm{N}$ atoms. Indeed, we found that the UVvis spectrum of 3-PE changes significantly in different solvents with very different coordination ability (Figure S60, THF, acetone, ether, DCM). While we believe it is possible to assign the binding mode in each solvent by performing detailed IR and ${ }^{15} \mathrm{~N} N M R$ measurements, such a study is beyond the scope of current work.

\section{O-nitrosation of $\mathrm{MeOH}$ with dicopper(II,III) $\mu-\mathrm{O} \mu$-NO.}

A unique feature of $S$-nitrosation via dicopper(II,III) $\mu-\mathrm{O} \mu-$ NO complex 2 is that the highly oxidizing $\mu$-O site can serve as an internal base and oxidant. This is in sharp contrast to previous mono-Fe and mono-Cu-based reductive $S$-nitrosation mechanisms, where thiols must be converted to thiolates and an external oxidant (Fe $\mathrm{Fe}^{\mathrm{III}}$ or $\left.\mathrm{Cu}^{\prime \prime}\right)$ is employed prior to S-NO bond formation. ${ }^{[34]}$ To understand the synergy between $\mu$-O and $\mu-\mathrm{NO}$ moieties in achieving the $S$-nitrosation, we sought to investigate the reaction of dicopper(II,III) $\mu$-O $\mu$-NO complex 2 with alcohols $(\mathrm{ROH})$, which are isoelectronic to thiol (Figure $4 \mathrm{~A}$ ) since no intermediate was observed en route to S-NO bond formation when 2 was treated with thiols. Metal nitrosyl complex capable of $S$-nitrosation can often perform analogous O-nitrosation of alcohol via similar mechanisms. ${ }^{[34,35,41]}$

Reaction of $\mathbf{2}$ with excess methanol leads to the formation of a new species 4 that absorbs at $475 \mathrm{~nm}\left(e=2200 \mathrm{M}^{-1} \mathrm{~cm}^{-1}\right)$, and $540 \mathrm{~nm}\left(e=2000 \mathrm{M}^{-1} \mathrm{~cm}^{-1}\right)$, which is stable up to $-30{ }^{\circ} \mathrm{C}$ (Figure S51). Compound 4 is EPR silent (Figure S68-69), suggesting two antiferromagnetically coupled Cull centers. In-situ low-temperature IR studies show that $\mathbf{4}$ exhibits a ${ }^{15} \mathrm{~N}$-sensitive stretch at $1567(-28) \mathrm{cm}^{-1}$, which is consistent with an $\mathrm{NO}^{-}$ moiety ${ }^{[2,42]}$ (Figure 4B). Single crystals of 4 were obtained by vapor diffusion of diethyl ether into a solution of $\mathbf{4}$ in methanol and toluene at $-40{ }^{\circ} \mathrm{C}$. X-ray diffraction analysis reveals a dicopper (II,II) $\mu$-NO $\mu$-OMe complex (Figure 4C). Besides the bridging nitrosyl and methoxy, Cu1 is coordinated by a triflate (OTf) anion and Cu2 is coordinated by a methanol solvent molecule, which is hydrogen-bonded with an outer sphere triflate (Figure S61). While the structure is of high quality, the $\mathrm{NO}$ and OMe ligand are in positional disorder, making the $\mathrm{N}-\mathrm{O}$ distance less reliable. Complex 4 is the second example of dicopper $\mu$-NO complex at $\mathrm{Cu}^{\prime \prime} \mathrm{Cu}^{\text {II }}$ oxidation state. Karlin et. al. reported the only other example of dicopper (II,II) $\mu$-NO complex, which was prepared by treatment of dicopper $(\mathrm{I}, \mathrm{I})$ precursor with nitrosonium $\left(\mathrm{NO}^{+}\right)$ salt. ${ }^{[42]}$
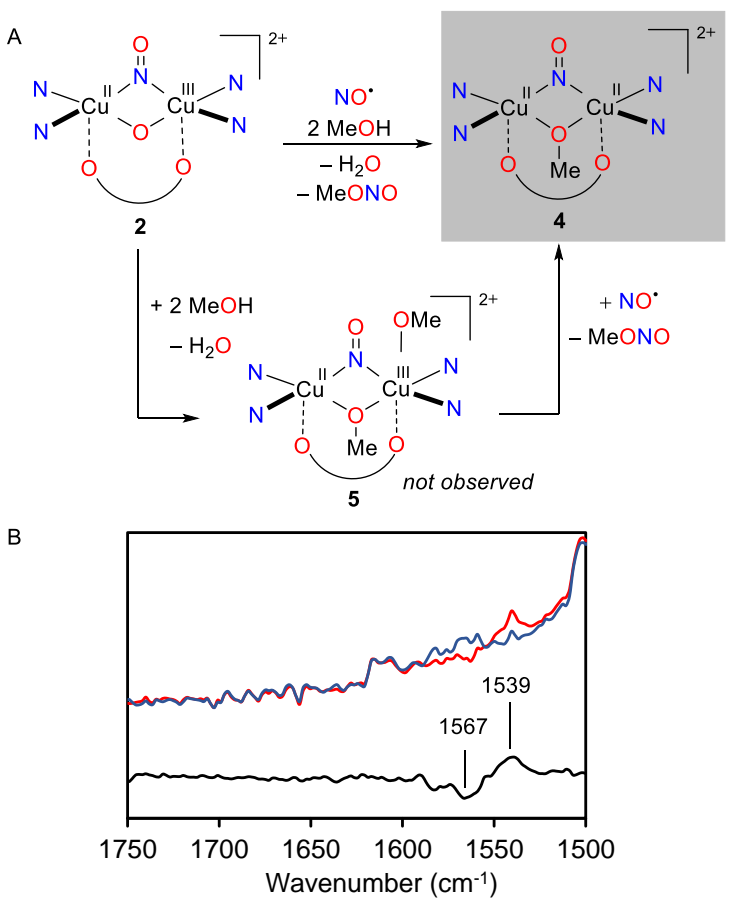

C

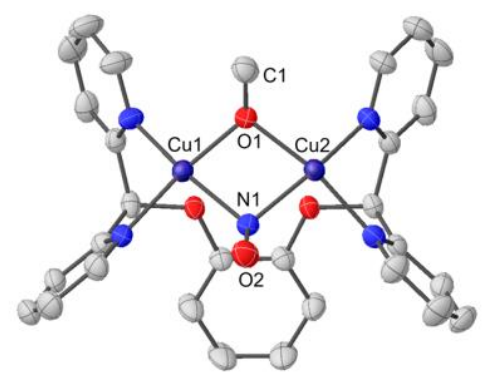

Figure 4. (A) Reaction scheme of 2 with $\mathrm{MeOH}$. (B) Solution IR spectrum (15 $\mathrm{mM}$, a mixture of DCM $(0.50 \mathrm{~mL})$, THF $(0.40 \mathrm{~mL})$ and methanol $(0.20 \mathrm{~mL})$ at $40{ }^{\circ} \mathrm{C}$ ) of $4-{ }^{-14} \mathrm{~N}$ (blue) and $4-{ }^{15} \mathrm{~N}$ (red). The difference spectrum of ${ }^{14} \mathrm{~N}$ and ${ }^{15} \mathrm{~N}$ sample is shown in black. (C) Solid-state structure of [ $\left.\mathrm{LCu}^{\prime \prime} \mathrm{Cu}(\mu-\mathrm{NO})(\mu-\mathrm{OMe})\right]$ complex 4 . Thermal ellipsoids are set at $50 \%$ probability. The triflate anions, solvent molecules, hydrogen atoms, and minor components of disordered atoms are omitted for clarity. Selected bond distance $(\AA)$ : Cu1-N1 = 1.976(16), $\mathrm{Cu} 2-\mathrm{N} 1=2.00(3), \mathrm{Cu} 1-\mathrm{O} 1=1.871(15), \mathrm{Cu} 2-\mathrm{O} 1=1.950(13), \mathrm{N} 1-\mathrm{O} 2=1.32(5)$, $\mathrm{N} 1 \mathrm{~B}-\mathrm{O} 2 \mathrm{~B}=1.27(4), \mathrm{Cu}-\mathrm{O} 1 \mathrm{~S}=2.227(3)$.

The $\mathrm{Cu}^{\text {"Cull }} \mathrm{Cxidation}$ state in $\mathbf{4}$ suggests a stepwise $\mathrm{O}$ nitrosation mechanism (Figure 4A). First, complex 2 undergoes protonation with methanol to generate a putative dicopper(II,III) $\mu$ NO $\mu$-alkoxide species 5 . Then, reductive $O$-nitrosation of the terminal methoxyl group in $\mathbf{5}$ causes a one-electron reduction of 
the dicopper(II,III) core and affords the observed product 4 with dicopper(II,II) oxidation states and MeO-NO. The characteristic "five-finger" UV-Vis feature of MeO-NO is observed at 325-380 $\mathrm{nm}$, when the reaction of $\mathbf{1}$ and $\mathrm{NO}$ is performed in $\mathrm{MeOH}$ at 0.2 $\mathrm{mM}$ concentration (Figure S54). This stepwise O-nitrosation mechanism to produce key dicopper (II,II) $\mu$-NO $\mu$-OMe intermediate 4 can be potentially applied in the analogous $S$ nitrosation reaction (Scheme 6). Since 2 can deprotonate $\mathrm{MeOH}$, it is reasonable to hypothesize that it can also deprotonate more acidic thiols to afford a putative dicopper(II,III) $\mu$-NO $\mu$-thiolate intermediate 6 . The terminal thiolate on 6 can undergo $S$ nitrosation to furnish the first RS-NO bond ${ }^{[22,23]}$ and generate 7 . Further RS-NO bond formation proceeds at the bridging thiolate to afford the second equivalent of RS-NO and eventually the complex 3-PE.

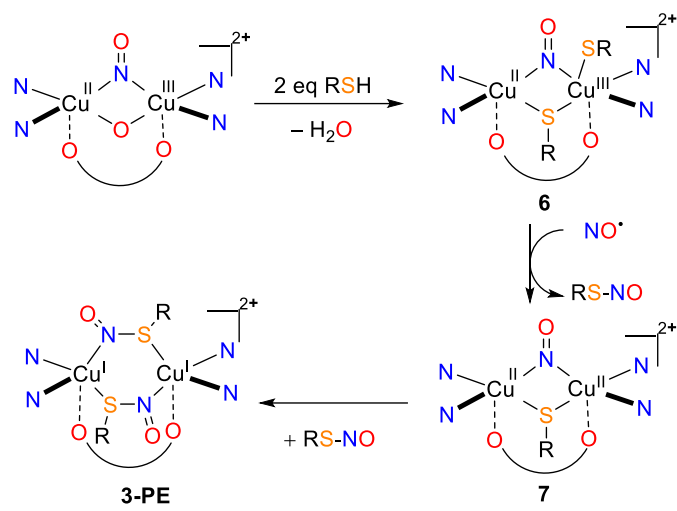

Scheme 6. The possible mechanistic pathway to generate 3-PE from dicopper(II,III) $\mu$-oxo, $\mu$-nitrosyl 2.

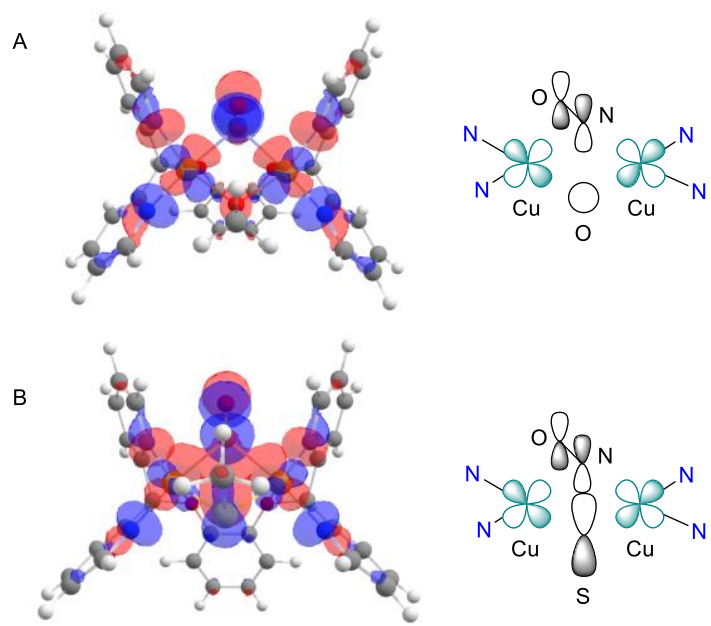

Figure 5. HOMO-1 of a truncated model of 4 and 7 rendered at a contour value of 0.03 .

Notably, while dicopper (II,II) $\mu$-NO, $\mu$-OMe complex 4 is stable enough for isolation, the isoelectronic dicopper (II,II) $\mu$-NO, $\mu$-SR complex 7 is not observed in the reaction even at $-80^{\circ} \mathrm{C}$. To further understand this key difference between dicopperpromoted $S$-nitrosation and $O$-nitrosation, the electronic structures of $\mathbf{4}$ and $\mathbf{7}$ are investigated by density functional theory (DFT) at B3LYP/TZVP/D3 level. To simplify our analysis, the axial ligands (OTf and $\mathrm{HOMe}$ ) are omitted in the calculation. The optimized geometry of a model of $\mathbf{4}$ agrees well with the X-ray single-crystal structure (Figure S61). A model of 7 with bridging SMe ligand is optimized as a comparison at the same level of theory. The most significant difference between the electronic structure of $\mathbf{4}$ and $\mathbf{7}$ is the HOMO-1, which is primarily composed of the copper $d$ orbitals and NO $\pi^{*}$ orbital (Figure 5). While the $\mathrm{HOMO}-1$ of 4 only has minimal density on the bridging OMe ligand (Figure $5 \mathrm{~A}$ ), the HOMO-1 of 7 displays significant contribution from the SMe $p$ orbital, which forms a $\sigma$ interaction with the nitrosyl $\pi^{*}$ orbital (Figure 5B). The better orbital overlap between $S$ and $\mathrm{NO}$ in comparison to $\mathrm{O}$ and $\mathrm{NO}$ might explain the high tendency of $\mathbf{7}$ to reductively eliminate RSNO.

\section{On the nitrosative reactivity of Ceruloplasmin}

Ceruloplasmin (CP), a copper protein that exists in high concentration in plasma $(1-5 \mu \mathrm{M}),{ }^{[43,44]}$ has been shown to catalyze the conversion of glutathione (GSH) to $S$ nitrosoglutathione in vivo. ${ }^{[7]} \mathrm{CP}$ contains several $\mathrm{T} 1$ electron transfer sites and a T2/T3 copper site. ${ }^{[45,46]}$ Previously, it was proposed that CP nitrosates thiol by oxidizing NO* to nitrosonium $\left(\mathrm{NO}^{+}\right)^{[7,47]}$ However, this mechanism contradicts the high aqueous oxidation potential of $\mathrm{NO}^{*}(+1.2 \mathrm{~V} \text { vs. } \mathrm{NHE})^{[48]}$ and mild redox potential of $\mathrm{Cp}\left(0.4-0.5 \mathrm{~V}\right.$ vs. NHE). ${ }^{[49]}$

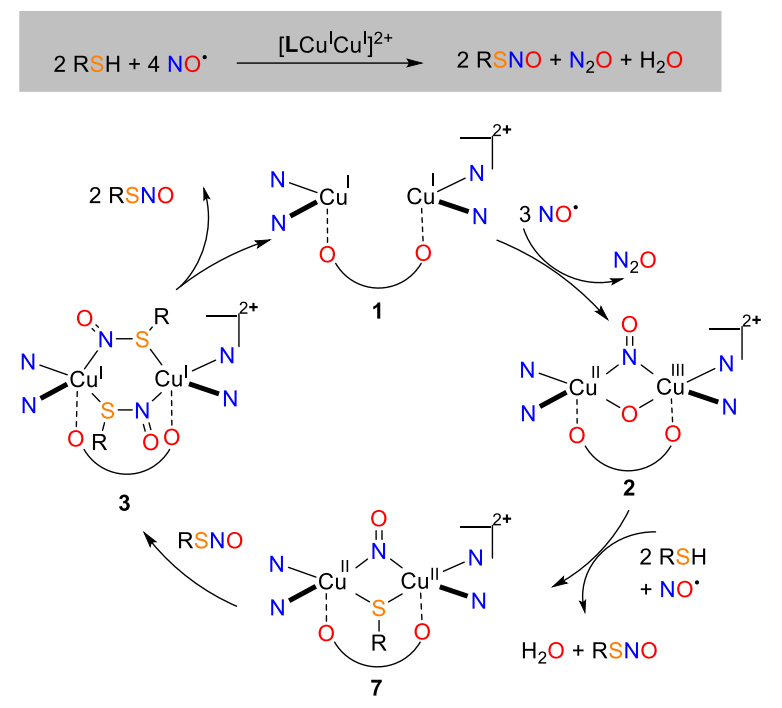

Figure 6. Proposed reaction cycles for redox- and proton-neutral coupling of $\mathrm{RSH}$ and $\mathrm{NO}^{\circ}$ to RSNO at a dicopper center.

The mechanistic steps established in this work has important implication in the S-nitrosation ability of CP (Figure 6). Considering complex $\mathbf{1}$ as a functional mimic of binuclear copper centers, a dicopper(II,III) $\mu$-O, $\mu$-NO species 2 can be accessed by activation of $\mathrm{NO}^{\circ}{ }^{[24]}$ Complex 2 undergoes stepwise $S$ nitrosation to afford dicopper(I,I) di- or mono-S-nitrosothiol complex 3. Release of $S$-nitrosothiol from 3 regenerates the dicopper $(I, I)$ species 1 and completes the reaction cycle. This new mechanism is fully consistent with the redox potential of $\mathrm{NO}^{\circ}$ and its reactivity at copper centers. S-nitrosation at T2/T3 site would require the participation of two of three $\mathrm{Cu}$, although the engagement of the third $\mathrm{Cu}$ is also possible. Excess $\mathrm{NO}^{\circ}$ could potentially coordinate to the $\mathrm{T} 1$ site and prevent electron transfer. However, this process would not impede the coupling of $\mathrm{NO}^{\circ}$ and thiol since the overall $S$-nitrosation reaction is redox-neutral. 


\section{Conclusion}

In contrast to the prevailing reductive $S$-nitrosation mechanism, we demonstrate that dicopper complex can promote redox- and proton-neutral $S$-nitrosation of thiols. A primary thiol, 2-phenylethanethiol is used as a model substrate to prove the proposed $S$-nitrosation process. We also show the $S$-nitrosation of bioinspired $\mathrm{N}$-acetyl- $L$-cysteine methyl ester to the corresponding RSNO. Spectroscopic characterization suggests that the dicopper $(\mathrm{I}, \mathrm{I})$ complex $\mathbf{1}$ can bind up to two equivalents of RSNO via $\mu-\kappa^{1}-\mathrm{N}$ : $\kappa^{1}-\mathrm{S}$ binding modes in THF and acetone. Reductive coupling of $\mathrm{NO}^{*}$ at biological and bioinspired $\mathrm{FeFe}$ or $\mathrm{FeCu}$ centers, e.g. NO reductase, are well known. ${ }^{[50]}$ Seminal work by Tolman and Karlin has shown that synthetic copper complexes can promote a similar $\mathrm{NO}^{*}$ coupling reaction and generate $\mathrm{N}_{2} \mathrm{O}$. We now demonstrate such a dicopper-promoted NO process could be a potential strategy to facilitate the storage of $\mathrm{NO}^{\circ}$ as $S$-nitrosothiol. The new redox-neutral $S$-nitrosation mechanism presented here potentially connects excess $\mathrm{NO}^{*}$ with an elevated level of S-nitrosothiols, adding further implications for the possible involvement of binuclear sites, such as T3, $\mathrm{Cu}_{\mathrm{A}}$ and dicopper amyloid b complexes, in the homeostasis of NO and $S$ nitrosothiols. Since dicopper(II,III) $\mu$-O $\mu$-NO complex 2 can be accessed by activation of nitrite $\left(\mathrm{NO}_{2}{ }^{-}\right)$, the reaction cycle depicted in Figure 6 is also relevant to $\mathrm{NO}_{2}^{-}$, another ubiquitous, air-stable source of $\mathrm{NO}$. Conversion of $\mathrm{NO}_{2}{ }^{-}$to low-mass $S$ nitrosothiols, e.g. S-nitrosoglutathione and $S$-nitrosocysteine, represents an alternative pathway to propagate nitrosative signals far from the dicopper sites. ${ }^{[32]}$

\section{Acknowledgements}

This material is based on work supported by the U.S. National Science Foundation under award No. CHE-1904560. Jamey Bower is acknowledged for EPR measurement and singlecrystal X-ray diffraction measurement. Tanya Whitmer is acknowledged for low-temperature NMR measurement. The authors thank The Ohio State University Department of Chemistry and Biochemistry for additional financial support.

Keywords: $S$-nitrosation $\cdot$ Copper $・$ Nitric oxide $\cdot O$-nitrosation $•$ Bimetallic

\section{Reference}

M. T. Forrester, M. Benhar, J. S. Stamler, ACS Chem. Biol. 2006, 1 355-358.

[2] T. Uehara, T. Nakamura, D. Yao, Z.-Q. Shi, Z. Gu, Y. Ma, E. Masliah, Y. Nomura, S. A. Lipton, Nature 2006, 441, 513-517.

[3] D. H. Cho, T. Nakamura, J. Fang, P. Cieplak, A. Godzik, Z. Gu, S. A. Lipton, Science 2009, 324, 102-106.
27069-27075

[8] P. Moriel, I. R. O. Pereira, M. C. Bertolami, D. S. P. Abdalla, Free Radic. Biol. Med. 2001, 30, 318-326.

[9] V. G. Kharitonov, A. R. Sundquist, V. S. Sharma, J. Biol. Chem. 1995, 270, 28158-28164

[10] M. N. Möller, Q. Li, J. R. Lancaster, A. Denicola, IUBMB Life 2007 , 59, 243-248.

[11] M. G. Espey, D. D. Thomas, K. M. Miranda, D. A. Wink, Proc. Natl. Acad. Sci. USA 2002, 99, 11127-11132.

[12] M. Boese, P. I. Mordvintcev, A. F. Vanin, R. Busse, A. Mulsch, J. Biol. Chem. 1995, 270, 29244-29249.

[13] A. F. Vanin, I. V. Malenkova, V. A. Serezhenkov, Nitric Oxide 1997, 1, 191-203.

[14] A. Weichsel, E. M. Maes, J. F. Andersen, J. G. Valenzuela, T. K. Shokhireva, F. A. Walker, W. R. Montfort, Proc. Natl. Acad. Sci. USA 2005, 102, 594-599.

[15] C. A. Bosworth, J. C. Toledo, J. W. Zmijewski, Q. Li, J. R. Lancaster, Proc. Natl. Acad. Sci. USA 2009, 106, 4671-4676.

[16] L. Tao, A. M. English, Biochemistry 2003, 42, 3326-3334.

[17] A. J. Jordan, R. K. Walde, K. M. Schultz, J. Bacsa, J. P. Sadighi, Inorg. Chem. 2019, 58, 9592-9596.

[18] V. K. K. Praneeth, F. Paulat, T. C. Berto, S. D. B. George, C. Näther C. D. Sulok, N. Lehnert, J. Am. Chem. Soc. 2008, 130, 15288-15303.

[19] N. Xu, D. R. Powell, L. Cheng, G. B. Richter-Addo, Chem. Commun 2006, 2030.

[20] A. P. Hunt, N. Lehnert, Inorg. Chem. 2019, 58, 11317-11332.

[21] B. P. Luchsinger, E. N. Rich, A. J. Gow, E. M. Williams, J. S. Stamler, D. J. Singel, Proc. Natl. Acad. Sci. USA 2003, 100, 461-466.

[22] S. Tian, J. Liu, R. E. Cowley, P. Hosseinzadeh, N. M. Marshall, Y. Yu, H. Robinson, M. J. Nilges, N. J. Blackburn, E. I. Solomon, et al., Nat. Chem. 2016, 8, 670-677.

[23] S. Zhang, M. M. Melzer, S. N. Sen, N. Çelebi-Ölçüm, T. H. Warren, Nat. Chem. 2016, 8, 663-669.

[24] W. Tao, J. K. Bower, C. E. Moore, S. Zhang, J. Am. Chem. Soc. 2019, 141, 10159-10164.

[25] M. Gennari, C. Duboc, Acc. Chem. Res. 2020, 53, 2753-2761.

[26] A. Franke, G. Stochel, N. Suzuki, T. Higuchi, K. Okuzono, R. van Eldik, J. Am. Chem. Soc. 2005, 127, 5360-5375.

[27] S. Basu, A. Keszler, N. A. Azarova, N. Nwanze, A. Perlegas, S. Shiva, K. A. Broniowska, N. Hogg, D. B. Kim-Shapiro, Free Radic. Biol. Med. 2010, 48, 255-263.

[28] K. A. Broniowska, A. Keszler, S. Basu, D. B. Kim-Shapiro, N. Hogg Biochem. J. 2012, 442, 191-197.

[29] S. F. Kim, D. A. Huri, S. H. Snyder, Science 2005, 310, 1966-1970.

[30] D. T. Hess, A. Matsumoto, S. O. Kim, H. E. Marshall, J. S. Stamler, Nat. Rev. Mol. Cell Biol. 2005, 6, 150-166.

[31] T. Rassaf, P. Kleinbongard, M. Preik, A. Dejam, P. Gharini, T. Lauer, J. Erckenbrecht, A. Duschin, R. Schulz, G. Heusch, et al., Circ. Res. 2002, 91, 470-477.

[32] S. Kundu, W. Y. Kim, J. A. Bertke, T. H. Warren, J. Am. Chem. Soc. 2017, 139, 1045-1048

[33] C. Zhang, T. D. Biggs, N. O. Devarie-Baez, S. Shuang, C. Dong, M. Xian, Chem. Commun. 2017, 53, 11266-11277.

[34] J. K. Bower, A. Y. Sokolov, S. Zhang, Angew. Chem. Int. Ed. 2019 58, 10225-10229; Angew. Chem. 2019, 131, 10331-10335.

[35] P. C. Ford, B. O. Fernandez, M. D. Lim, Chem. Rev. 2005, 105, 2439-2455. 
[36] I. G. Dance, J. Chem. Soc., Chem. Commun. 1976, 68-69.

[37] V. Hosseininasab, A. C. McQuilken, A. (Gus) Bakhoda, J. A. Bertke, Q. K. Timerghazin, T. H. Warren, Angew. Chem. Int. Ed. 2020, 59 , 10854-10858; Angew. Chem. 2020, 132, 10946-10950.

[38] N. Hendinejad, Q. K. Timerghazin, Phys. Chem. Chem. Phys. 2020, 22, 6595-6605.

[39] Q. K. Timerghazin, G. H. Peslherbe, A. M. English, Org. Lett. 2007, 9, 3049-3052.

[40] L. L. Perissinotti, D. A. Estrin, G. Leitus, F. Doctorovich, J. Am. Chem. Soc. 2006, 128, 2512-2513.

[41] M. M. Melzer, S. Jarchow-Choy, E. Kogut, T. H. Warren, Inorg. Chem. 2008, 47, 10187-10189.

[42] P. P. Paul, Z. Tyeklar, A. Farooq, K. D. Karlin, S. Liu, J. Zubieta, J. Am. Chem. Soc. 1990, 112, 2430-2432.

[43] P. Bielli, L. Calabrese, Cell. Mol. Life Sci. C. 2002, 59, 1413-1427.

[44] N. E. Hellman, J. D. Gitlin, Annu. Rev. Nutr. 2002, 22, 439-458.

[45] E. I. Solomon, U. M. Sundaram, T. E. Machonkin, Chem. Rev. 2002, 96, 2563-2606.

[46] N. Mano, H.-H. Kim, A. Heller, J. Phys. Chem. B 2002, 106, 8842 8848.

[47] A. Dejam, C. J. Hunter, M. M. Pelletier, L. L. Hsu, R. F. Machado, S. Shiva, G. G. Power, M. Kelm, M. T. Gladwin, A. N. Schechter, Blood 2005, 106, 734-739.

[48] D. M. Stanbury, in Adv. Inorg. Chem. (Ed.: A.G.B.T.-A. in I.C. Sykes), Academic Press, 1989, pp. 69-138.

[49] T. E. Machonkin, E. I. Solomon, J. Am. Chem. Soc. 2000, 122, 12547-12560.

[50] C. Ferousi, S. H. Majer, I. M. Dimucci, K. M. Lancaster, Chem. Rev. 2020, 120, 5252-5307. 
Electronic Supporting Information for:

\section{Redox-neutral $S$-nitrosation Mediated by a Dicopper Center}

Wenjie Tao, Curtis E. Moore, and Shiyu Zhang*

Department of Chemistry and Biochemistry, The Ohio State University, Columbus, Ohio 43210

\section{Contents}

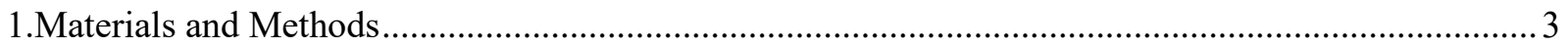

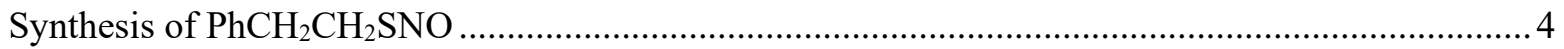

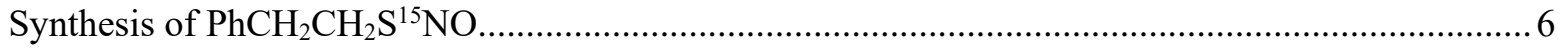

Synthesis of $\mathrm{N}$-acetyl- $L$-cysteine methyl ester $S$-nitrosothiol ........................................................ 9

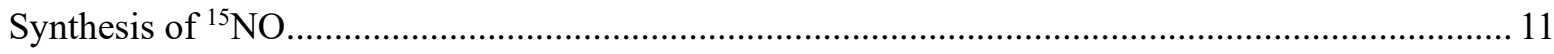

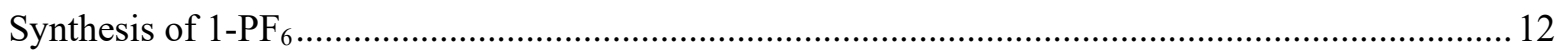

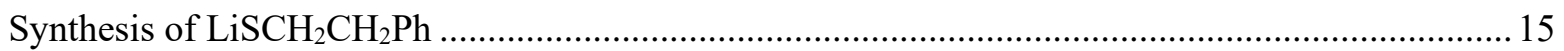

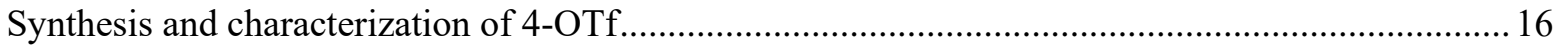

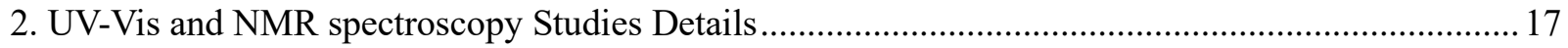

Reaction of 1- $\mathrm{BAr}_{4}{ }_{4}$ with 2.0 eq. $\mathrm{PhCH}_{2} \mathrm{CH}_{2} \mathrm{SNO}$ in acetone .................................................... 17

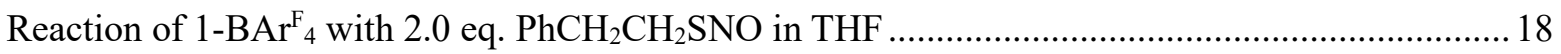

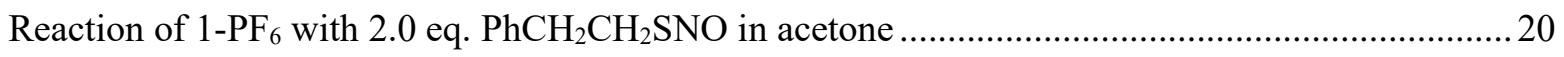

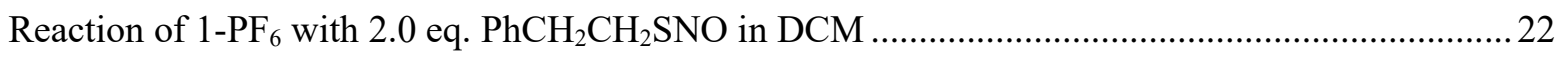

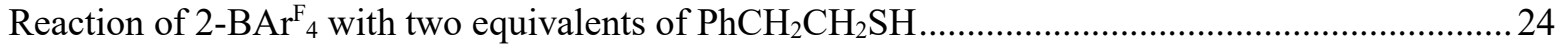

Reaction of 1- $\mathrm{BAr}_{4}{ }_{4}$ with 2.0 eq. $\mathrm{PhCH}_{2} \mathrm{CH}_{2} \mathrm{SNO}$ in propionitrile..............................................2

Reaction of excess propionitrile with proposed dicopper(I,I) di-S-nitrosothiol................................29

Quantification of $\mathrm{PhCH}_{2} \mathrm{CH}_{2} \mathrm{SNO}$ from the reaction of 2- $\mathrm{BAr}_{4}{ }_{4}$ with two equivalents of $\mathrm{PhCH}_{2} \mathrm{CH}_{2} \mathrm{SH}$

Quantification of $\mathrm{PhCH}_{2} \mathrm{CH}_{2} \mathrm{SNO}$ from the reaction of 2- $\mathrm{BAr}_{4}{ }_{4}$ with two equivalents of $\mathrm{PhCH}_{2} \mathrm{CH}_{2} \mathrm{SH}$

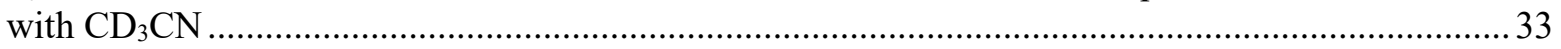


Reaction of 1-BAr ${ }_{4}{ }_{4}$ with 2.0 eq. N-acetyl- $L$-cysteine methyl ester $S$-nitrosothiol in acetone ............ 36

Reaction of 2-BAr${ }_{4}{ }_{4}$ with 2.0 eq. $\mathrm{N}$-acetyl- $L$-cysteine methyl ester in acetone................................. 38

Quantification of $S$-nitroso $\mathrm{N}$-acetyl- $L$-cysteine methyl ester from the reaction of 2-BAr ${ }_{4}{ }_{4}$ with two equivalents of $\mathrm{N}$-acetyl- $L$-cysteine methyl ester ...................................................................... 40

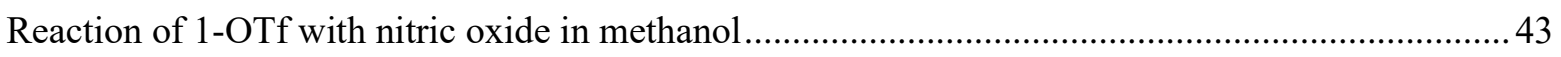

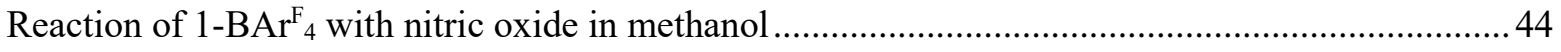

Reaction of 1-BAr${ }_{4}{ }_{4}$ with nitric oxide in methanol at $0.20 \mathrm{mM}$ concentration................................ 46

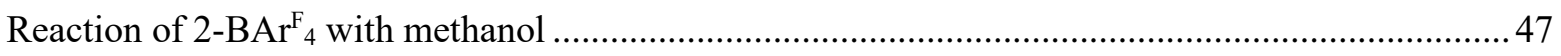

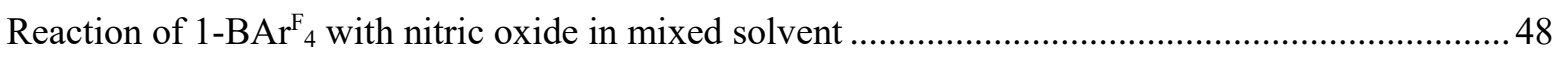

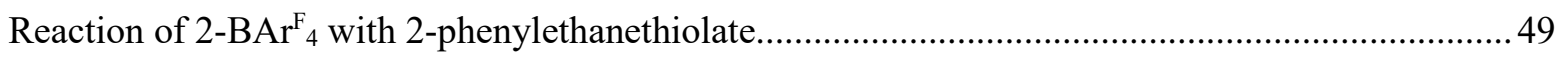

${ }^{15} \mathrm{~N}$ NMR characterization of proposed dicopper(I,I) di-S-nitrosothiol ..........................................50

Solvent effect on $S$-nitroso-2-phenylethanethiol binding to dicopper(I,I) complex..........................55

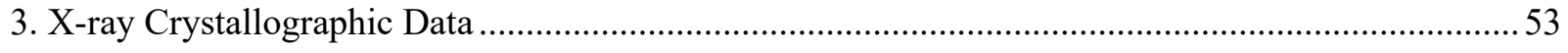

4. In-situ IR to investigate $\mathrm{N}=\mathrm{O}$ stretching frequency .................................................................5 56

IR of 1-BAr ${ }_{4}{ }_{4}$ reacting with two equivalents of $\mathrm{PhCH}_{2} \mathrm{CH}_{2} \mathrm{SNO}$ and $\mathrm{PhCH}_{2} \mathrm{CH}_{2} \mathrm{~S}^{15} \mathrm{NO}$ in THF- $d_{8} . .56$

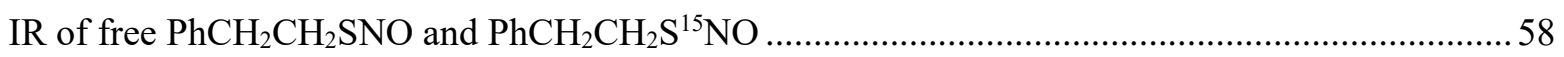

IR of 1-OTf reacting with $\mathrm{NO}$ and ${ }^{15} \mathrm{NO}$ in the presence of methanol .........................................59

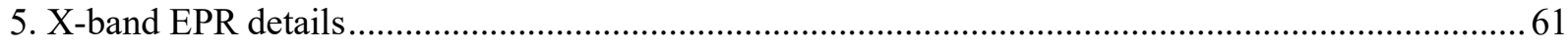

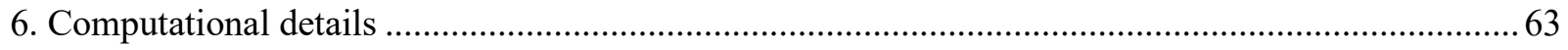

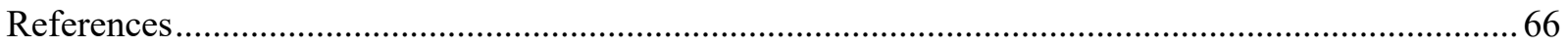




\section{Materials and Methods}

General: All reactions were carried out under a nitrogen atmosphere in an MBraun glovebox or using Schlenk techniques. All glassware was dried at $120{ }^{\circ} \mathrm{C}$ prior to use.

Instrumentation: Nuclear magnetic resonance (NMR) spectra were recorded on AVIII HD $600 \mathrm{MHz}\left({ }^{1} \mathrm{H}\right.$ : $\left.600 \mathrm{MHz},{ }^{13} \mathrm{C}: 151 \mathrm{MHz}\right)$ or Bruker $850 \mathrm{MHz}$ Ascend $\left({ }^{1} \mathrm{H}: 850 \mathrm{MHz},{ }^{13} \mathrm{C}: 214 \mathrm{MHz}\right)$ at ambient temperature unless otherwise noted. Chemical shift values for protons are referenced to the residual proton resonance of chloroform- $d_{1}(\delta: 7.26 \mathrm{ppm})$, acetone- $d_{6}(\delta: 2.05 \mathrm{ppm})$, THF- $d_{8}(\delta: 3.58 \mathrm{ppm})$ or $\mathrm{CD}_{3} \mathrm{CN}(\delta: 1.94 \mathrm{ppm})$. Chemical shift values for carbons are referenced to the carbon resonance of chloroform- $d(\delta: 77.16 \mathrm{ppm})$, acetone- $d_{6}(\delta: 206.26 \mathrm{ppm}), \mathrm{THF}-d_{8}(\delta: 67.21 \mathrm{ppm})$ or $\mathrm{CD}_{3} \mathrm{CN}(\delta: 118.26 \mathrm{ppm})$. X-ray crystallographic analyses were performed under a cold nitrogen stream (Oxford Cryosystems Cryostream) at 150(2) or 100 (2) $\mathrm{K}$ on a Bruker D8 Venture instrument with Mo Ka radiation source $(\lambda=0.7107 \AA)$ and a Photon II detector. Elemental analyses were performed by Midwest Micro Lab (Indianapolis, IN, http://midwestlab.com/). High-resolution mass spectra were recorded on a Bruker MicrOTOF (ESI). EPR measurements were performed in $4 \mathrm{~mm}$ low-pressure quartz tubes on a Bruker EMXPlus X-band EPR spectrometer equipped with a Coldedge cryostat with small-volume power saturation. Solution in-situ IR was recorded on a Mettler Toledo RiR15 spectrometer.

Materials: NO (>99.99\%) was purchased from Praxair and purified by passing through a column of Ascarite (8-20 mesh, Sigma-Aldrich) and collected in a Schlenk flask type glassware at $1 \mathrm{~atm}$. A specific volume of $\mathrm{NO}(\mathrm{g})$ was collected and injected into the reaction flask for the reactions using $\mathrm{NO}(\mathrm{g})$. Dichloromethane, acetonitrile, diethyl ether, pentane, tetrahydrofuran was dried and degassed under nitrogen using a Pure Process Technologies (PPT, Nashua, NH) solvent purification system, and stored over $4 \AA$ molecular sieves. Anhydrous acetone was purchased from Acros and was used as received. Anhydrous toluene was dried and degassed under nitrogen using Pure Solv Innovative Technology solvent purification system and stored over $4 \AA$ molecular sieves. $\mathrm{CDCl}_{3}, \mathrm{CD}_{3} \mathrm{CN}$, THF- $d_{8}$, and acetone- $d_{6}$ (Cambridge Isotope Laboratories, Inc.) were dried over $4 \AA$ molecular sieves and deoxygenated by three freeze-pump-thaw cycles prior to use. 2-Phenylethanethiol (Sigma-Aldrich), 1-adamantanethiol (SigmaAldrich), 4-methoxythiophenol (Sigma-Aldrich), 4-bromothiophenol (Alfa Aesar), trifluoroacetic acid (Sigma-Aldrich), sodium nitrite- ${ }^{15} \mathrm{~N}$ (Cambridge Isotope Laboratories, Inc.), di(2-pyridyl)ketone (CombiBlocks), $\mathrm{NaBH}_{4}$ (Merck KGaA), carbon tetrachloride (Sigma-Aldrich), catechol (Acros), tetrakis(acetonitrile) copper(I) tetrafluoroborate (Sigma-Aldrich), tetrakis(acetonitrile) copper(I) triflate (Sigma-Aldrich), tetrakis(acetonitrile) copper(I) hexafluorophosphate (Sigma-Aldrich), LHMDS (Acros) were purchased and used without further purification. $\mathrm{NaB}\left[3,5-\left(\mathrm{CF}_{3}\right)_{2} \mathrm{C}_{6} \mathrm{H}_{4}\right]_{4} \quad\left(\mathrm{NaBAr}_{4}\right),{ }^{[1]} 2,2^{\prime}-$ (chloromethylene)dipyridine, ${ }^{[2]} \mathrm{Cu}(\mathrm{MeCN})_{4} \mathrm{BAr}_{4}{ }_{4},{ }^{[3]} \mathrm{N}$-acetyl $L$-cysteine methyl ester ${ }^{[4]}$ were synthesized following the literature procedures. 


\section{Synthesis of $\mathrm{PhCH}_{2} \mathrm{CH}_{2} \mathrm{SNO}$}

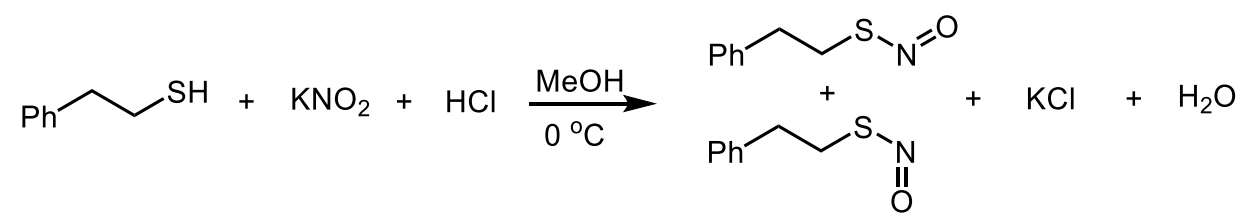

The synthesis of $\mathrm{PhCH}_{2} \mathrm{CH}_{2} \mathrm{SNO}$ is enlightened by the reported literature precedents ${ }^{[5-7]}$ and modified as follows. In the glove box, 2-phenylethanethiol (166 mg, $161 \mu \mathrm{L}, 1.20 \mathrm{mmol}, 1.0 \mathrm{eq}$.) and potassium nitrite (205 mg, $2.40 \mathrm{mmol}, 2.0$ eq.) were dissolved in $c a .10 \mathrm{~mL}$ of methanol and then transferred into a $15 \mathrm{~mL}$ pressure flask. The flask was taken out of glove box, connected to Schlenk line, and cooled in an ice/water bath. Under positive nitrogen flow, $\mathrm{HCl}(2.40 \mathrm{mmol}, 0.60 \mathrm{~mL}$ of $4.0 \mathrm{M}$ in dioxane, 2.0 eq.) was injected into the above solution and the mixture was stirred at this temperature for $c a$. $1.0 \mathrm{~h}$. The flask was transferred back into the glove box and the suspension was concentrated under vacuum. Pentane ( $c a .10 \mathrm{~mL}$ ) was added to extract the product. The pentane solution was filtered through a plug of Celite and the plug was washed with additional pentane $c a .3 .0 \mathrm{~mL}$. The combined filtrate was dried under vacuum for $2.0 \mathrm{~h}$, affording a red oil product $(155 \mathrm{mg}, 77 \%)$, which can be stored in the freezer of the glove box at $-35{ }^{\circ} \mathrm{C}$ for months. Based on literature precedents, $S$-nitrosothiols are usually light sensitive. While handing $\mathrm{PhCH}_{2} \mathrm{CH}_{2} \mathrm{SNO}_{\text {, }}$ we tried to avoid light. The ${ }^{13} \mathrm{C}$ NMR spectroscopic results (Figures $\mathrm{S} 2$ and $\mathrm{S} 3$ ) of product $\mathrm{PhCH}_{2} \mathrm{CH}_{2} \mathrm{SNO}$ at room temperature are consistent with those reported in literature precedents in that there are syn and anti isomers via rotation around $\mathrm{S}-\mathrm{N}$ bond ${ }^{[5]}$.

${ }^{1} \mathrm{H}$ NMR (600 MHz, $\left.\mathrm{CDCl}_{3}\right) \delta$ 7.34-7.20 (m, 5H), 3.02-2.99 (m, 2H), 2.97-2.94 (m, 2H). The other isomer has signals at $\delta 3.77(\mathrm{~b}, 2 \mathrm{H}), 2.84(\mathrm{~b}, 2 \mathrm{H})$. We observe two sets of ${ }^{1} \mathrm{H}$ NMR signals corresponding to the syn and anti isomers. The aromatic signals are overlapped at region $\delta$ 7.34-7.20. Based on the ${ }^{1} \mathrm{H}$ NMR integrals, the ratio of the two isomers is $c a 1: 1$.

${ }^{13} \mathrm{C} \mathrm{NMR}\left(151 \mathrm{MHz}, \mathrm{CDCl}_{3}\right) \delta 140.19,128.79$ (2C), 128.70 (2C), 126.56, 40.37, 35.89. The other isomer has signals at $\delta 139.35,128.76(2 \mathrm{C}), 128.63$ (2C), 126.95, 35.33, 34.96. We observe two sets of ${ }^{13} \mathrm{C}$ NMR signals corresponding to the syn and anti isomers (Figure S2).

We were unable to characterize the titled compound by HRMS-ESI due to its instability. 


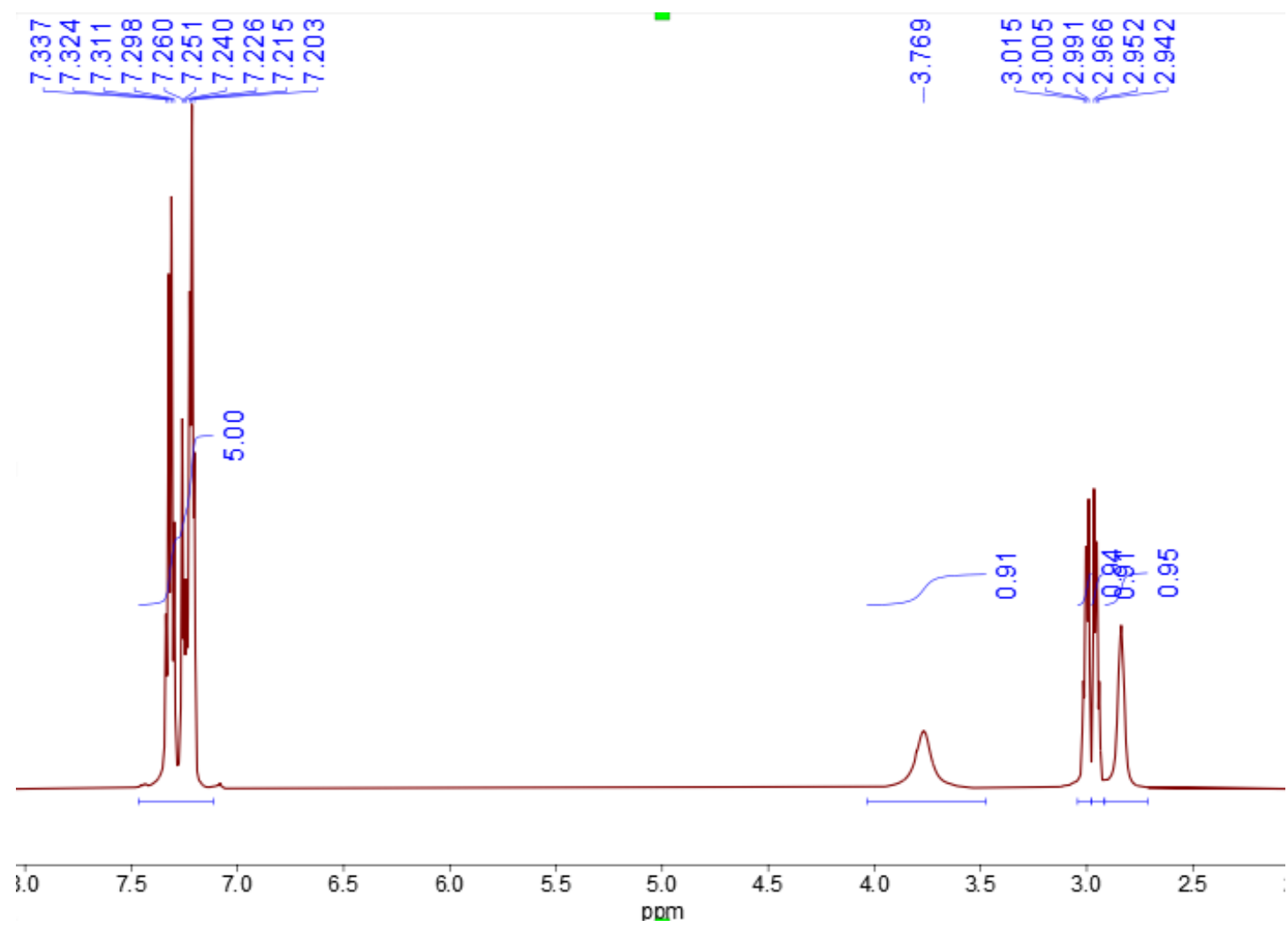

Figure S1: ${ }^{1} \mathrm{H}$ NMR $\left(600 \mathrm{MHz}, \mathrm{CDCl}_{3}\right)$ spectrum of compound $\mathrm{PhCH}_{2} \mathrm{CH}_{2} \mathrm{SNO}$.

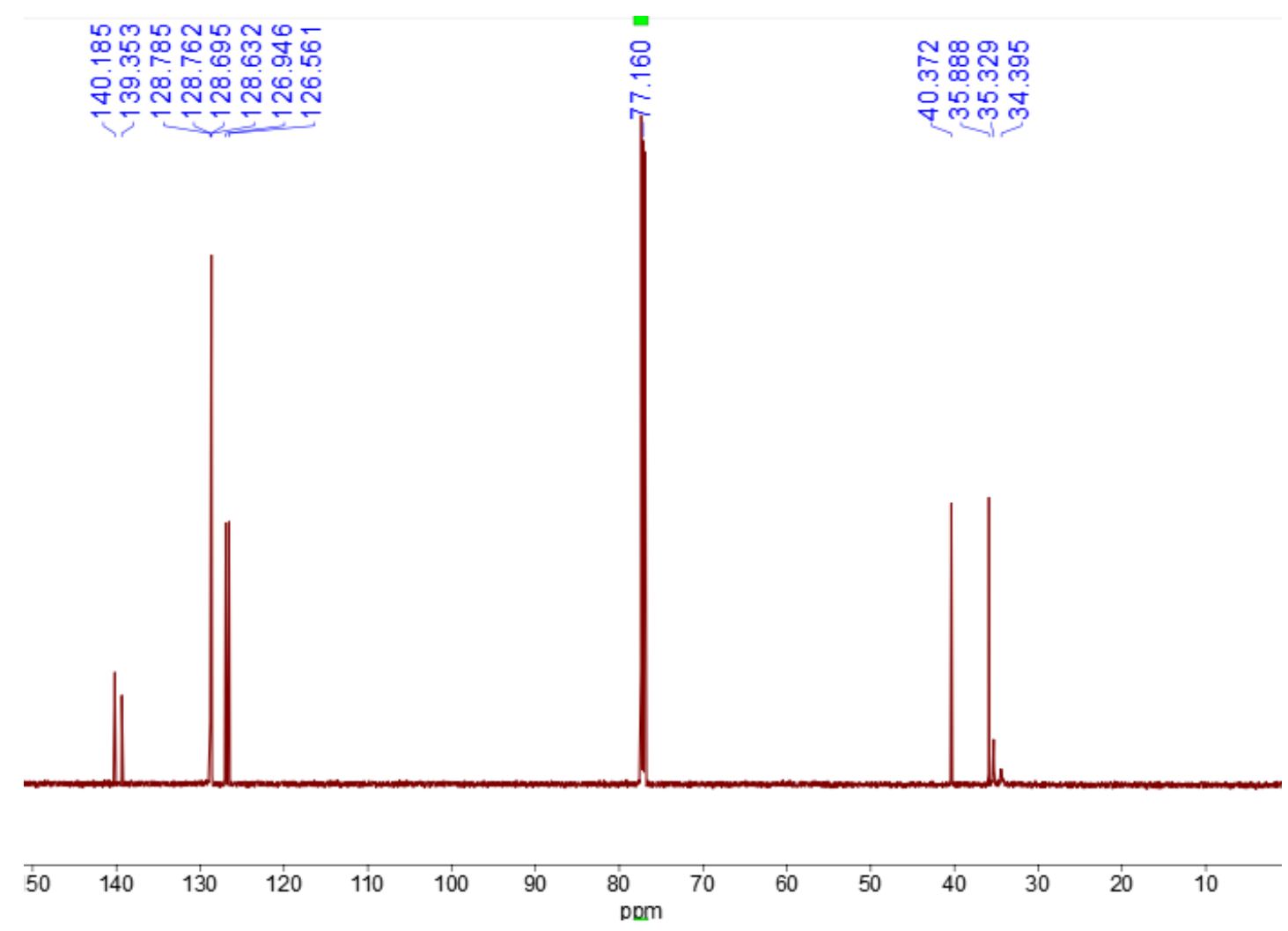

Figure S2: ${ }^{13} \mathrm{C} \mathrm{NMR}\left(151 \mathrm{MHz}, \mathrm{CDCl}_{3}\right)$ spectrum of compound $\mathrm{PhCH}_{2} \mathrm{CH}_{2} \mathrm{SNO}$. 

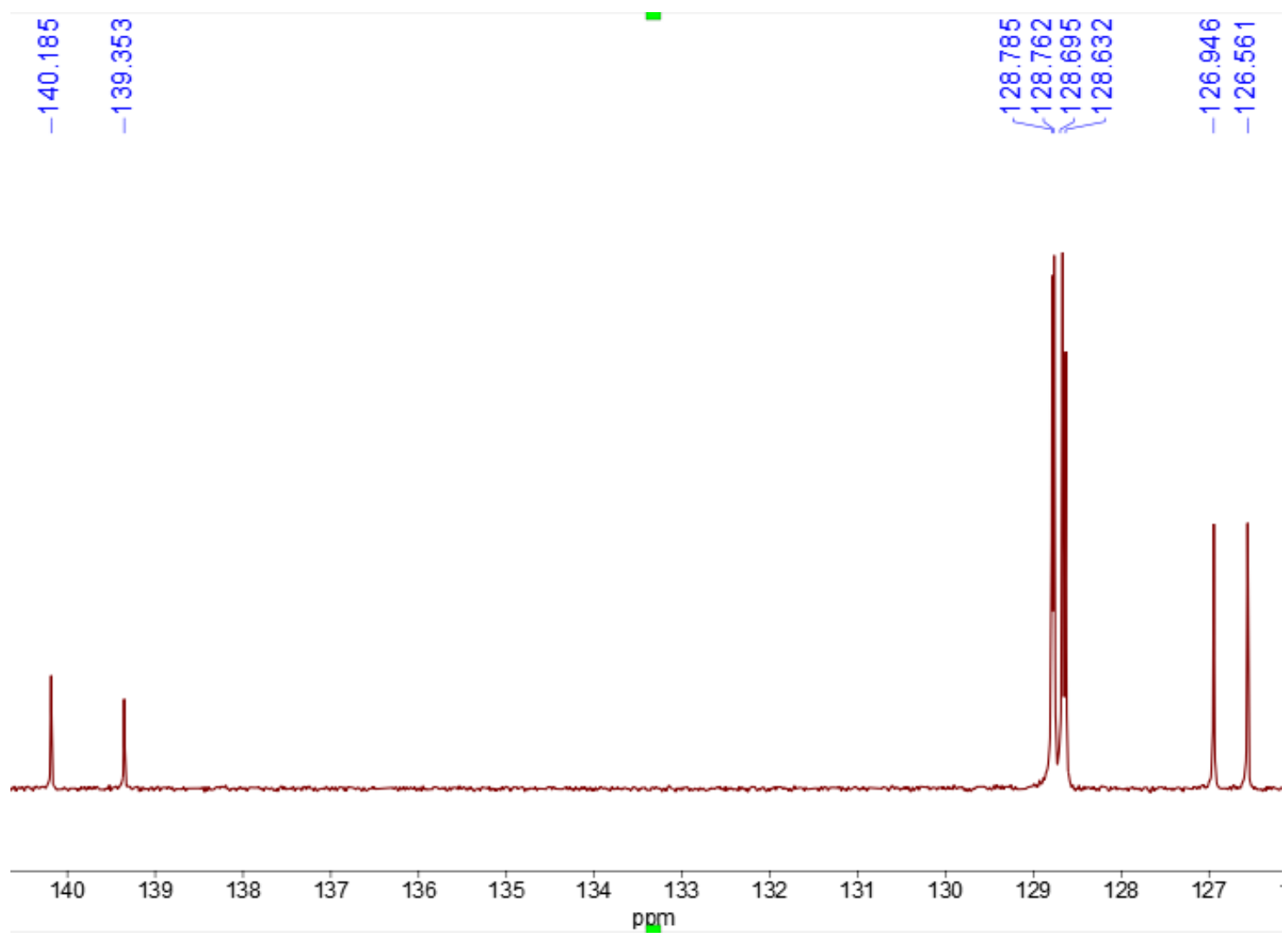

Figure S3: ${ }^{13} \mathrm{C}$ NMR (151 MHz, $\mathrm{CDCl}_{3}$ ) spectrum (126-141ppm) of compound $\mathrm{PhCH}_{2} \mathrm{CH}_{2} \mathrm{SNO}$.

\section{Synthesis of $\mathrm{PhCH}_{2} \mathrm{CH}_{2} \mathrm{~S}^{15} \mathrm{NO}$}

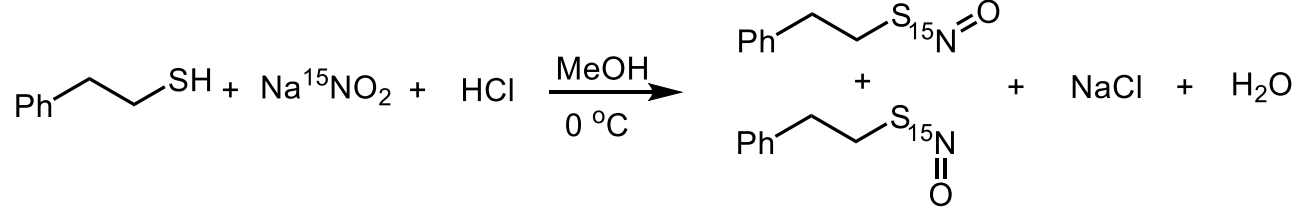

In the glove box, phenyl ethanethiol $(247 \mathrm{mg}, 1.79 \mathrm{mmol}, 1.0$ eq. $)$ and sodium nitrite- ${ }^{15} \mathrm{~N}(150 \mathrm{mg}, 2.14$ mmol, 1.2 eq.) were dissolved in $c a .10 \mathrm{~mL}$ of methanol and then transferred into a $15 \mathrm{~mL}$ pressure flask. The flask was taken out of glove box, connected to Schlenk line, and cooled in an ice/water bath. Under positive nitrogen flow, $\mathrm{HCl}(2.14 \mathrm{mmol}, 0.54 \mathrm{~mL}$ of $4.0 \mathrm{M}$ in dioxane, $1.2 \mathrm{eq}$.) was injected into the above solution and the mixture was stirred at this temperature for $c a .1 .0 \mathrm{~h}$. The flask was transferred back into the glove box and the suspension was concentrated under vacuum. Pentane $c a .10 \mathrm{~mL}$ was added to extract the product. The pentane solution was filtered through a plug of Celite and the plug was washed with additional pentane $c a .3 .0 \mathrm{~mL}$. The combined filtrate was dried under vacuum for $2.0 \mathrm{~h}$, affording a red oil product ( $254 \mathrm{mg}, 84 \%)$.

${ }^{1} \mathrm{H}$ NMR $\left(600 \mathrm{MHz}, \mathrm{CDCl}_{3}\right) \delta$ 7.19.-7.32 (m, 5H), $3.75(\mathrm{~b}, 2 \mathrm{H}), 2.82(\mathrm{~b}, 2 \mathrm{H})$; The other isomer has signals at: $\delta 2.98-3.01(\mathrm{~m}, 2 \mathrm{H}), 2.93-2.96(\mathrm{~m}, 2 \mathrm{H})$. Based on the ${ }^{1} \mathrm{H}$ NMR, the ratio of the two isomers is $0.80: 1.13$ $=1: 1.41$. 
${ }^{13} \mathrm{C}$ NMR $\left(151 \mathrm{MHz}, \mathrm{CDCl}_{3}\right) \delta 140.14,128.72(2 \mathrm{C}), 128.62(2 \mathrm{C}), 126.52,40.33,35.84$. The other isomer's signals are: $\delta 139.30,128.74(2 \mathrm{C}), 128.59(2 \mathrm{C}), 126.90,35.28,34.36$.

${ }^{15} \mathrm{~N}$ NMR $\left(61 \mathrm{MHz}, \mathrm{CDCl}_{3}\right) \delta 771.1$ vs. $\mathrm{NH}_{3}$.

We were unable to characterize the titled compound by HRMS-ESI due to its instability.

忿市
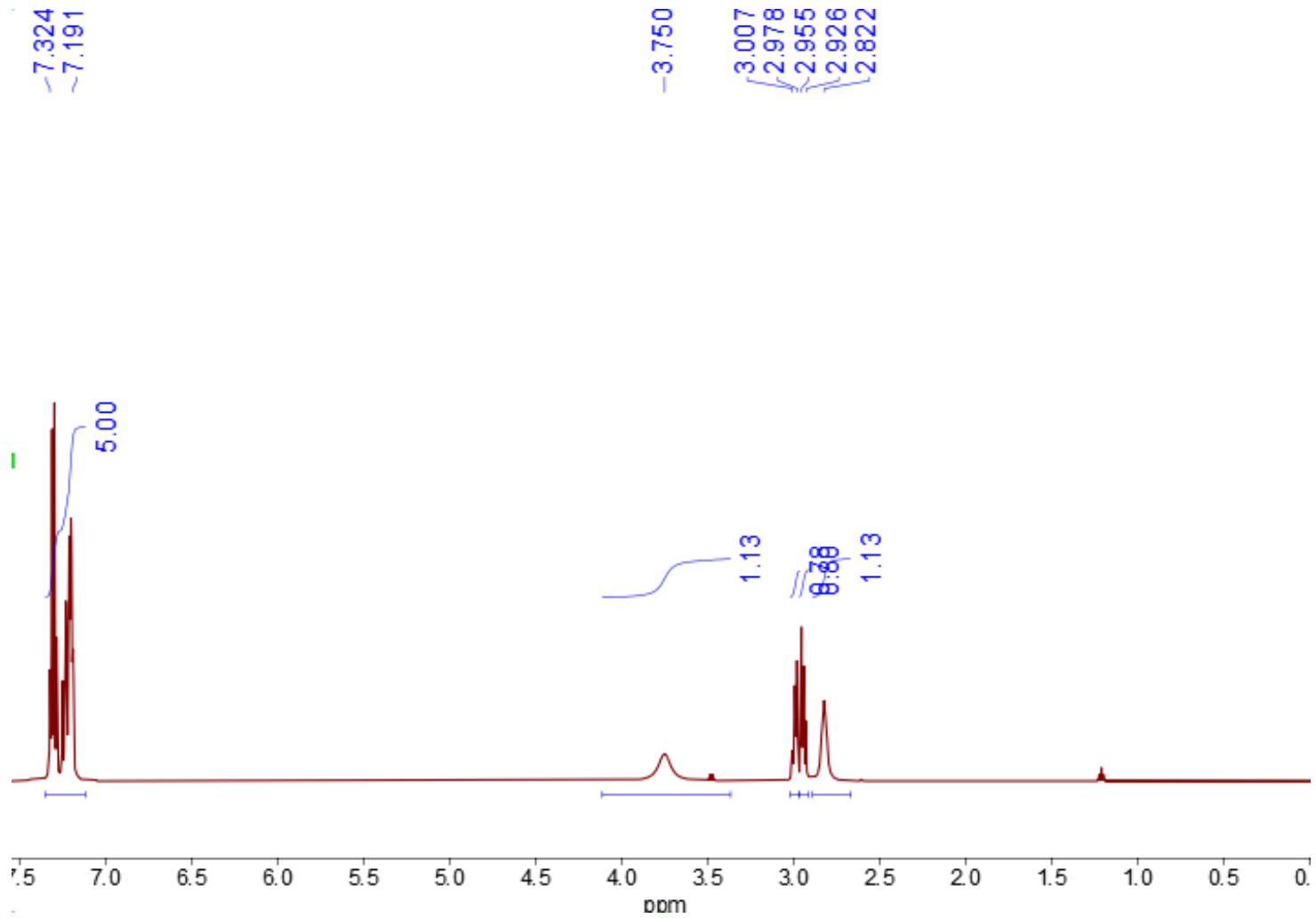

Figure S4: ${ }^{1} \mathrm{H}$ NMR $\left(600 \mathrm{MHz}, \mathrm{CDCl}_{3}\right)$ spectrum of compound $\mathrm{PhCH}_{2} \mathrm{CH}_{2} \mathrm{~S}^{15} \mathrm{NO}$. 

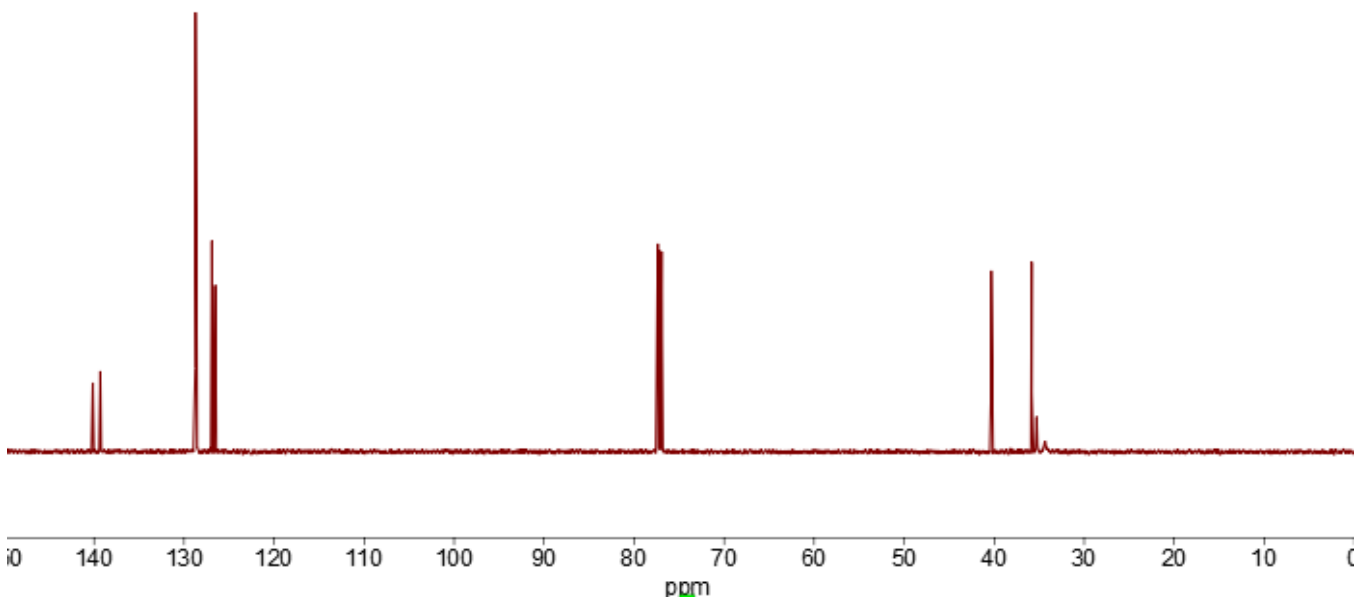

Figure S5: ${ }^{13} \mathrm{C}$ NMR $\left(151 \mathrm{MHz}, \mathrm{CDCl}_{3}\right)$ spectrum of compound $\mathrm{PhCH}_{2} \mathrm{CH}_{2} \mathrm{~S}^{15} \mathrm{NO}$.

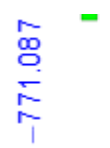

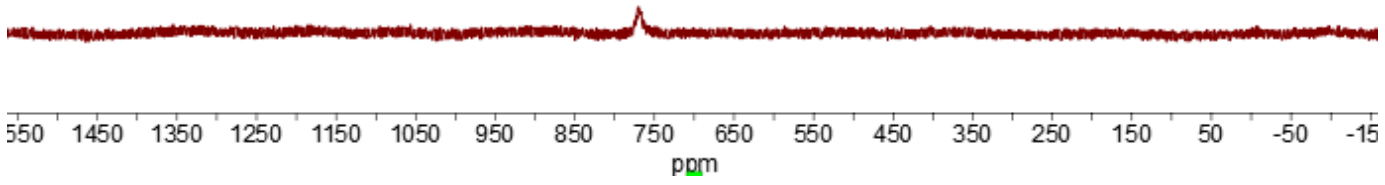

Figure S6: ${ }^{15} \mathrm{~N} \mathrm{NMR}\left(61 \mathrm{MHz}, \mathrm{CDCl}_{3}\right.$ ) spectrum of compound $\mathrm{PhCH}_{2} \mathrm{CH}_{2} \mathrm{~S}^{15} \mathrm{NO}$. The ${ }^{15} \mathrm{~N}$ chemical shift is referenced to $\mathrm{NH}_{3}(0 \mathrm{ppm})$. 


\section{Synthesis of $\mathrm{N}$-acetyl- $L$-cysteine methyl ester $S$-nitrosothiol}

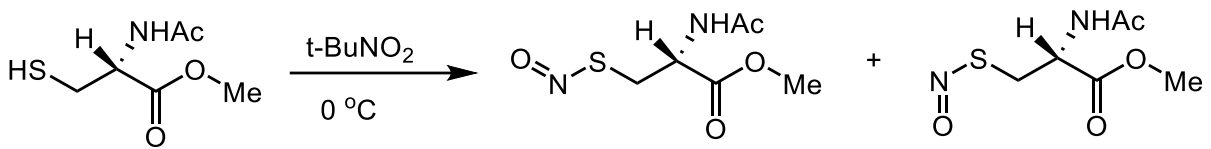

In the glove box, $\mathrm{N}$-acetyl- $L$-cysteine methyl ester (400 mg, $2.26 \mathrm{mmol}, 1.0 \mathrm{eq}$ ) was dissolved in $\mathrm{ca} .4 .0$ $\mathrm{mL}$ of tetrahydrofuran and transferred into a $15 \mathrm{~mL}$ pressure flask. The pressure flask was taken out of the glove box, connected to Schlenk line, and cooled in $-5^{\circ} \mathrm{C}$ cold bath. Under positive nitrogen flow, tertbutyl nitrite $(90 \%, 0.60 \mathrm{~mL}, 4.51 \mathrm{mmol}, 2.0 \mathrm{eq})$ was injected into the above flask and the mixture was stirred at this temperature overnight. The color of the solution changed from colorless to dark red. The pressure flask was still maintained in the ice/water bath and connected to a vacuum to remove the volatiles. (Note: the product is unstable at RT, especially under vacuum.) The cold pressure flask was quickly transferred back to the glove box. Diethyl ether $c a$. $3.0 \mathrm{~mL}$ was used to extract the product and quickly filtered through a plug of celite. The plug was washed with additional diethyl ether $c a .2 .0 \mathrm{~mL}$. Pentane (ca. $10 \mathrm{~mL}$ ) was layered on the top of the combined filtrate, and the vial was stored in the freezer of glove box at $-35^{\circ} \mathrm{C}$ overnight. The supernatant was decanted and the red crystals were quickly dried under vacuum for $c a$. 10 seconds. The vial was put back to the freezer and cooled again before a second drying for 10 seconds under vacuum, affording a red solid product (150 mg, $0.727 \mathrm{mmol}, 32 \%$ ). Elemental analysis was not performed because of its thermal instability.

${ }^{1} \mathrm{H}$ NMR (600 MHz, acetone- $\left.d_{6}\right) \delta 7.49$ (s, 1H), 4.78-4.63 (m, 1H), 4.22-4.04 (m, 2H), 3.69 (s, 3H), 1.88 (s, $3 \mathrm{H})$.

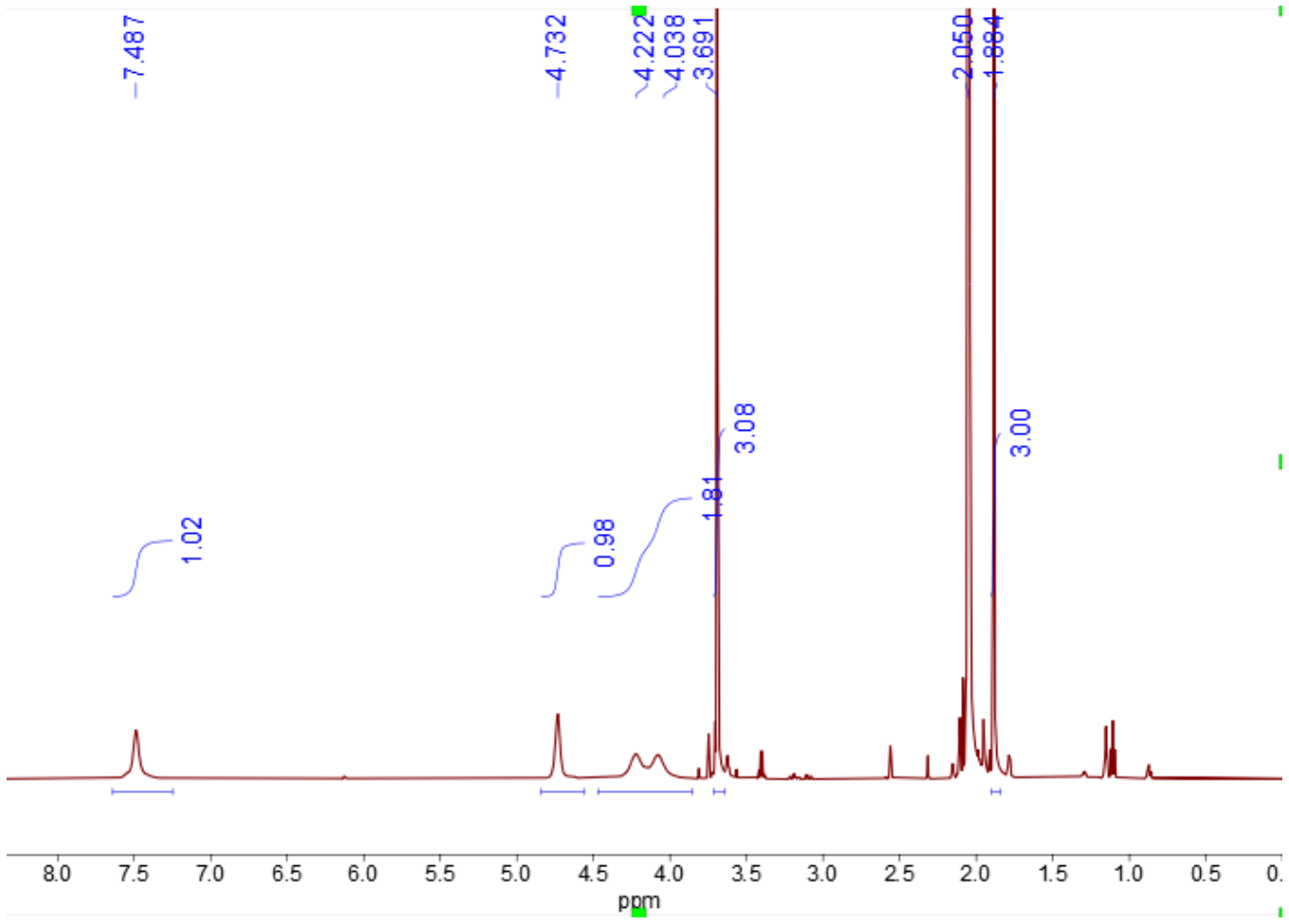

Figure S7: ${ }^{1} \mathrm{H}$ NMR $\left(600 \mathrm{MHz}\right.$, acetone- $\left.d_{6}\right)$ spectrum of $\mathrm{N}$-acetyl-L-cysteine methyl ester $S$-nitrosothiol.

${ }^{1} \mathrm{H} \mathrm{NMR}$ in $\mathrm{CDCl}_{3}$ was measured in $\mathrm{CDCl}_{3}$ as well, where we observe more clear evidence of the presence of two isomers. 
${ }^{1} \mathrm{H}$ NMR (600 MHz, CDCl $) \delta 6.09(\mathrm{~s}, 1 \mathrm{H}), 4.97-5.00(\mathrm{~m}, 1 \mathrm{H}), 4.10-4.26(\mathrm{~m}, 2 \mathrm{H}), 3.73(\mathrm{~s}, 3 \mathrm{H}), 1.97$ (s, $3 \mathrm{H})$. The other isomer's signals are: $\delta 6.50(\mathrm{~d}, J=7.2 \mathrm{~Hz}, 1 \mathrm{H}), 4.89-4.86(\mathrm{~m}, 1 \mathrm{H}), 3.77(\mathrm{~s}, 3 \mathrm{H}), 2.06(\mathrm{~s}$, $3 \mathrm{H})$. The methylene signals of two isomers are overlapped.

${ }^{13} \mathrm{C} \mathrm{NMR}\left(151 \mathrm{MHz}, \mathrm{CDCl}_{3}\right) \delta 170.41,169.90,53.09,51.78,40.90,34.99,23.09$.

The other isomer's signals are: $\delta 171.01,170.13,52.92,51.86,23.24$. Two carbon signals of the two isomers are overlapped.

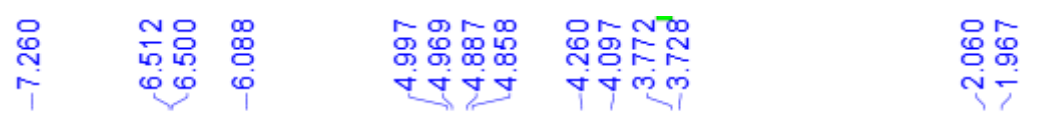

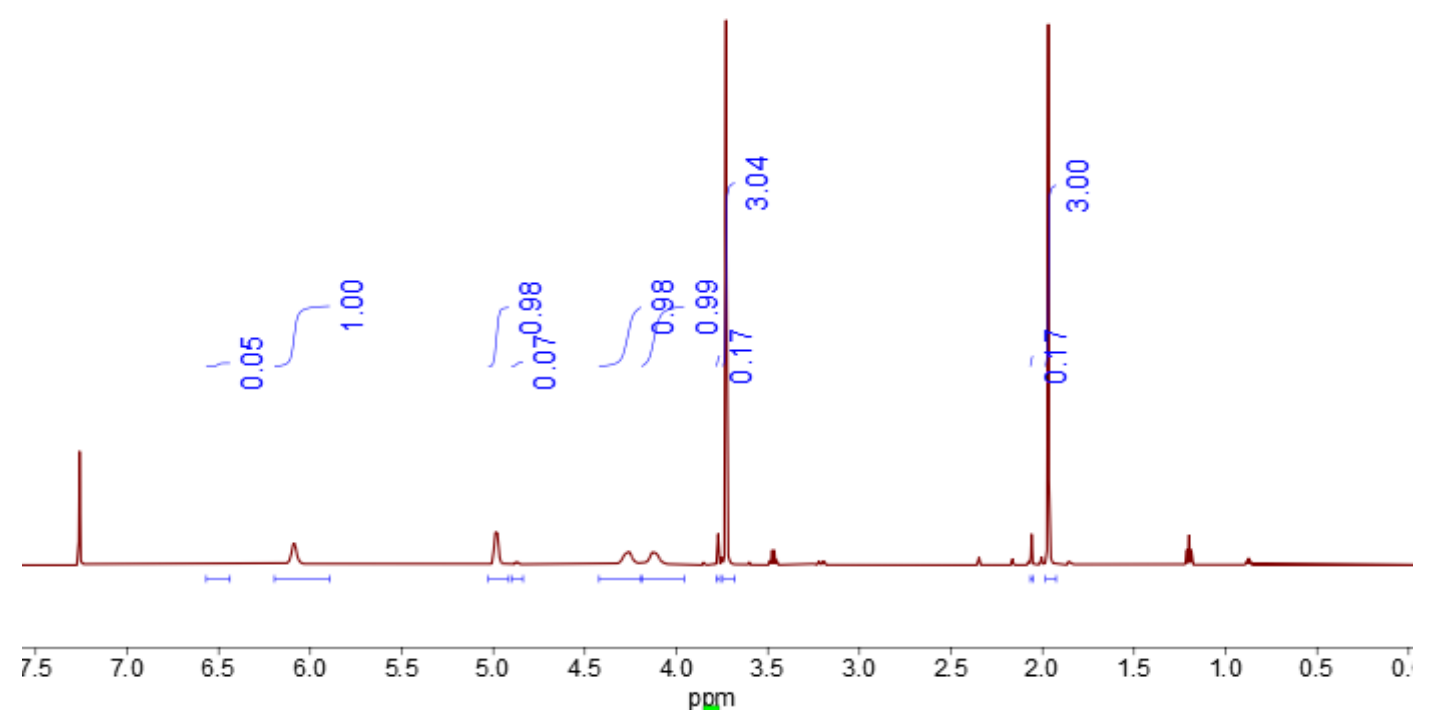

Figure S8: ${ }^{1} \mathrm{H} \mathrm{NMR}\left(600 \mathrm{MHz}, \mathrm{CDCl}_{3}\right)$ spectrum of $\mathrm{N}$-acetyl- $L$-cysteine methyl ester $S$-nitrosothiol. 


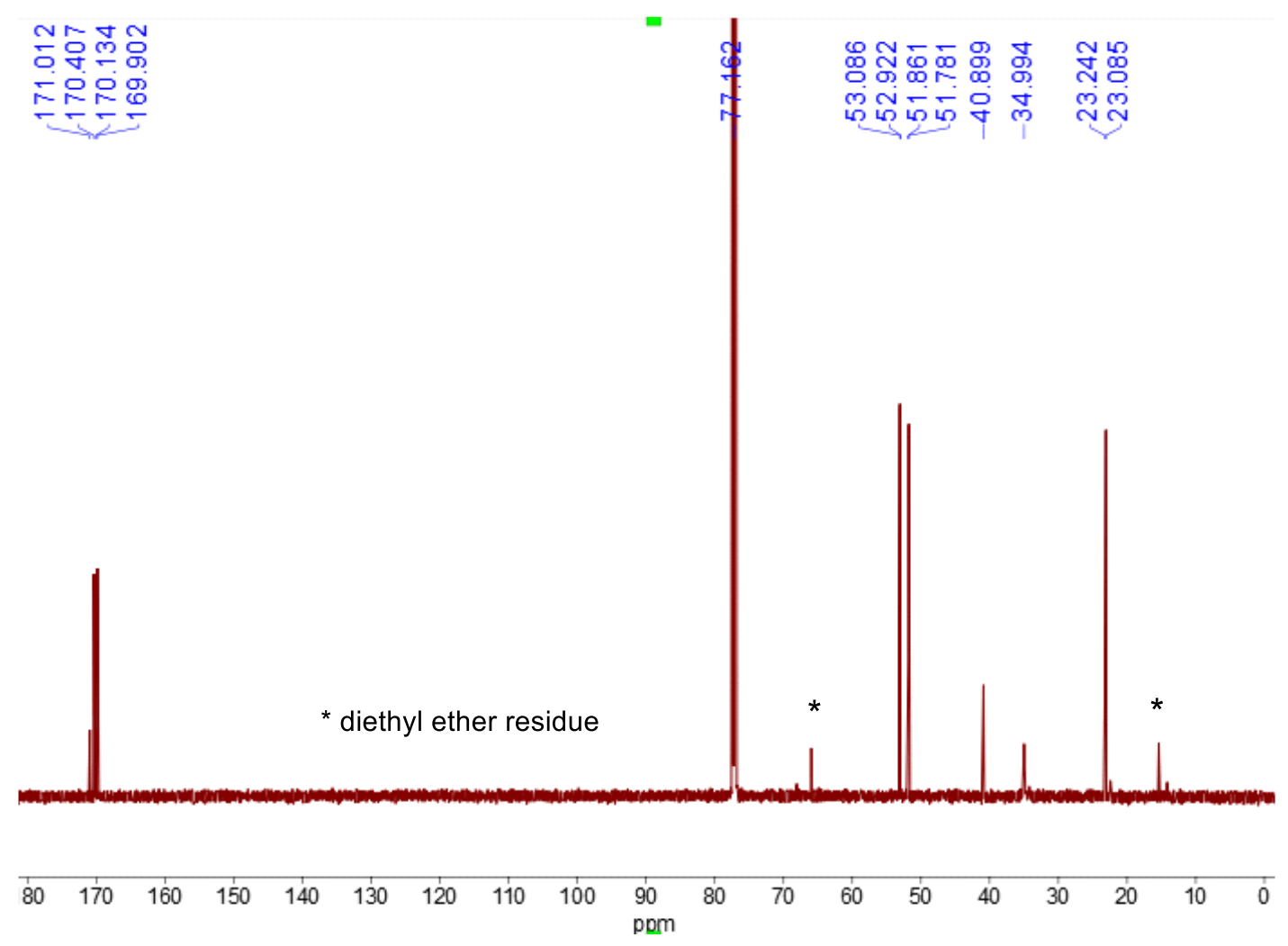

Figure S9: ${ }^{1} \mathrm{H}$ NMR $\left(151 \mathrm{MHz}, \mathrm{CDCl}_{3}\right)$ spectrum of $\mathrm{N}$-acetyl- $L$-cysteine methyl ester $S$-nitrosothiol.

\section{Synthesis of ${ }^{15} \mathrm{NO}$}

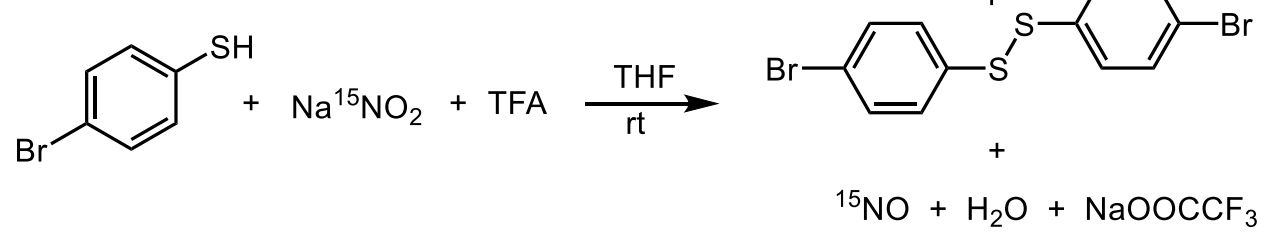

In the glove box, to a $20 \mathrm{~mL}$ scintillation vial with septum seal, 4-bromothiophenol (74.2 $\mathrm{mg}, 0.393 \mathrm{mmol}$, 1.1 eq.), sodium nitrite- ${ }^{15} \mathrm{~N}(25.0 \mathrm{mg}, 0.357 \mathrm{mmol}, 1.0$ eq. $)$, and degassed dry tetrahydrofuran $(2.0 \mathrm{~mL})$ were added. The vial was cooled in the glove box freezer $\left(-35^{\circ} \mathrm{C}\right)$ for $\mathrm{ca} .5 \mathrm{~min}$, and trifluoroacetic acid $(26$ $\mu \mathrm{L}, 0.339 \mathrm{mmol}, 0.95$ eq.) was injected into the above suspension. The scintillation vial was quickly sealed and a $10 \mathrm{~mL}$ syringe with a $20 \mathrm{~cm}$ long needle was used to collect the generated ${ }^{15} \mathrm{NO}$ immediately. After stirring the mixture at RT for $c a .20 \mathrm{~min}, c a .7 .0 \mathrm{~mL}$ of gas was collected, which contained both nitrogen gas and ${ }^{15} \mathrm{NO}$.

Theoretically, ${ }^{15} \mathrm{NO}(0.339 \mathrm{mmol}, 8.1 \mathrm{~mL})$ was formed under these conditions and the headspace contained ca. $18 \mathrm{~mL}$ of nitrogen originally. So in the $7.0 \mathrm{~mL}$ of gas collected in the syringe $c a .7 .0 \times 8.1 /(8.1+18)=$ $2.2 \mathrm{~mL}$ of ${ }^{15} \mathrm{NO}(0.092 \mathrm{mmol})$ was included, if we consider ${ }^{15} \mathrm{NO}$ dissolved in the solvent is negligible. 


\section{Synthesis of 1-PF 6}

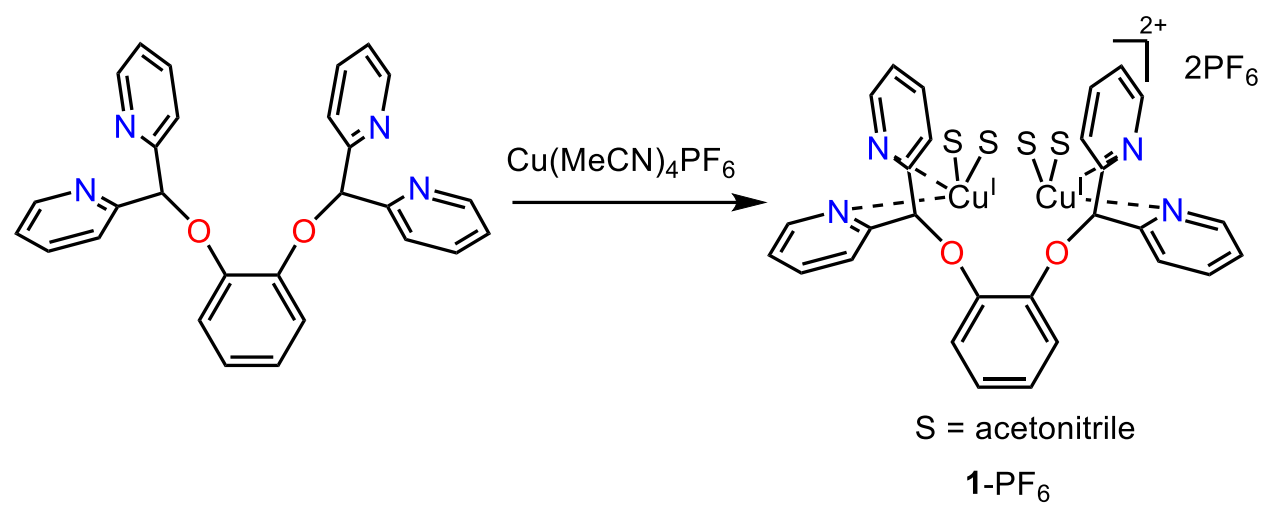

In the glove box, ligand $\mathbf{L}(150 \mathrm{mg}, 0.336 \mathrm{mmol}, 1.0$ equiv.) and tetrakis(acetonitrile) copper(I) hexafluorophosphate $(261 \mathrm{mg}, 0.679 \mathrm{mmol}, 2.02$ equiv.) were dissolved in acetonitrile (ca. $4.0 \mathrm{~mL})$, and the resulting mixture was stirred at room temperature overnight. After the reaction, all volatiles were removed under vacuum and the crude product was washed with a mixture of THF (ca. $6.0 \mathrm{~mL})$ and diethyl ether $(c a .3 .0 \mathrm{~mL})$ twice. The remaining solid was extracted with acetonitrile $(c a .1 .5 \mathrm{~mL})$ and filtered through a plug of Celite, and the plug was washed with additional acetonitrile (ca. $1.0 \mathrm{~mL})$. Diethyl ether (ca. $12 \mathrm{~mL}$ ) was slowly layered on the top of the acetonitrile, and the mixture was stored in $\mathrm{a}-40{ }^{\circ} \mathrm{C}$ freezer overnight to afford a yellow oily residue. The supernatant was decanted and the yellow oil was dried under vacuum for $c a .1 .5 \mathrm{~h}$, affording a yellow solid $1-\mathrm{PF}_{6}(358 \mathrm{mg}, 99 \%)$.

${ }^{1} \mathrm{H}$ NMR $\left(600 \mathrm{MHz}, \mathrm{CD}_{3} \mathrm{CN}\right) \delta 8.63(\mathrm{~d}, J=3.0 \mathrm{~Hz}, 4 \mathrm{H}), 7.89(\mathrm{t}, J=7.8 \mathrm{~Hz}, 4 \mathrm{H}), 7.82(\mathrm{~d}, J=7.8 \mathrm{~Hz}, 4 \mathrm{H})$, $7.42(\mathrm{t}, J=6.6 \mathrm{~Hz}, 4 \mathrm{H}), 7.00-6.98(\mathrm{~m}, 2 \mathrm{H}), 6.89-6.87(\mathrm{~m}, 2 \mathrm{H}), 6.63(\mathrm{~s}, 2 \mathrm{H}), 1.97(\mathrm{~s}, 12 \mathrm{H})$.

${ }^{13} \mathrm{C}$ NMR $\left(214 \mathrm{MHz}, \mathrm{CD}_{3} \mathrm{CN}\right) \delta 157.48,150.61,147.94,139.62,125.38,124.07,122.96,82.34$.

${ }^{19} \mathrm{~F}$ NMR $\left(565 \mathrm{MHz}, \mathrm{CD}_{3} \mathrm{CN}\right) \delta-73.0(\mathrm{~d}, J=707 \mathrm{~Hz})$.

${ }^{31} \mathrm{P}$ NMR $\left(243 \mathrm{MHz}, \mathrm{CD}_{3} \mathrm{CN}\right) \delta-144.6$ (sep, $\left.J=707 \mathrm{~Hz}\right)$.

Elemental analysis, Calcd for $\mathrm{C}_{36} \mathrm{H}_{34} \mathrm{Cu}_{2} \mathrm{~F}_{12} \mathrm{~N}_{8} \mathrm{O}_{2} \mathrm{P}_{2}$ : C, 42.07; H, 3.33; N, 10.90. Found: $\mathrm{C}, 42.66 ; \mathrm{H}, 3.48$; $\mathrm{N}, 10.59$. 


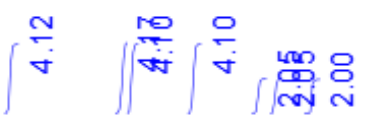
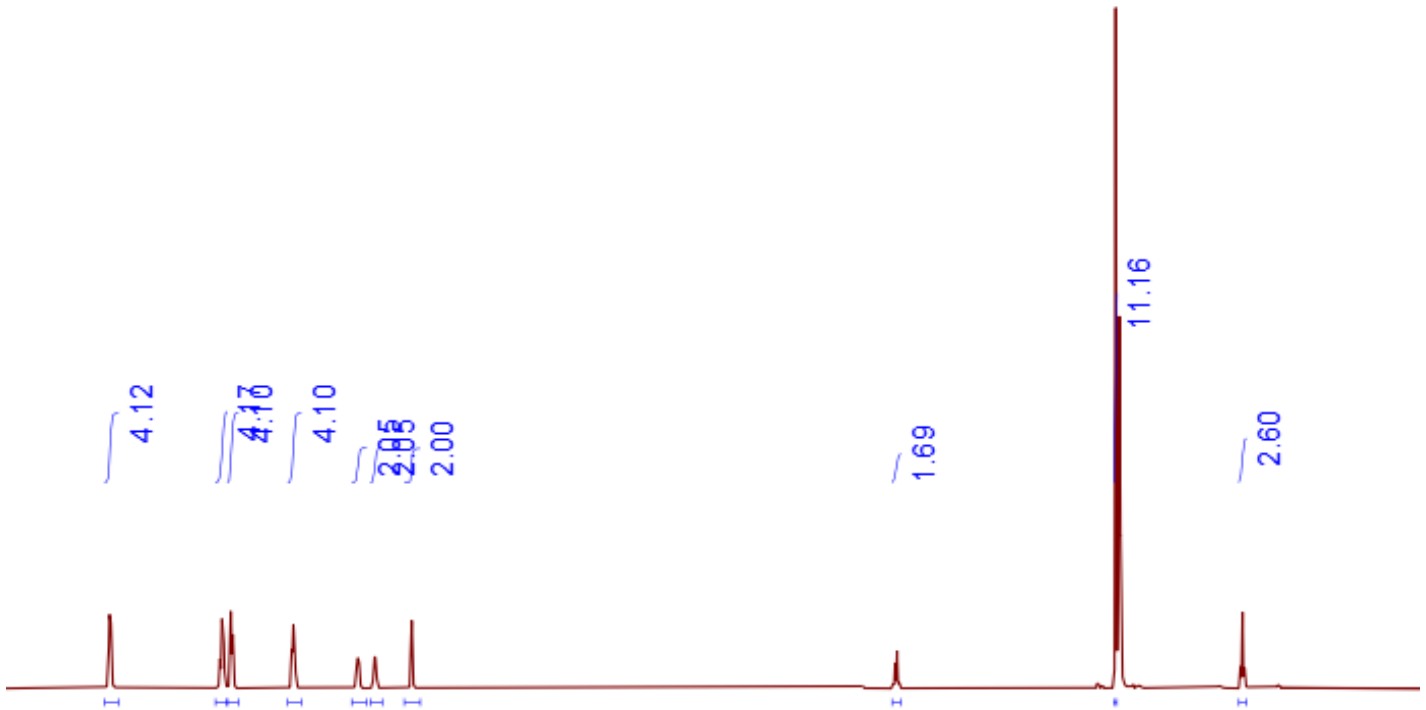

$9.0 \quad 8.5 \quad 8.0$ $\mathrm{ppm}$

Figure S10: ${ }^{1} \mathrm{H}$ NMR $\left(600 \mathrm{MHz}, \mathrm{CD}_{3} \mathrm{CN}\right)$ spectrum of compound 1-PF 6 .
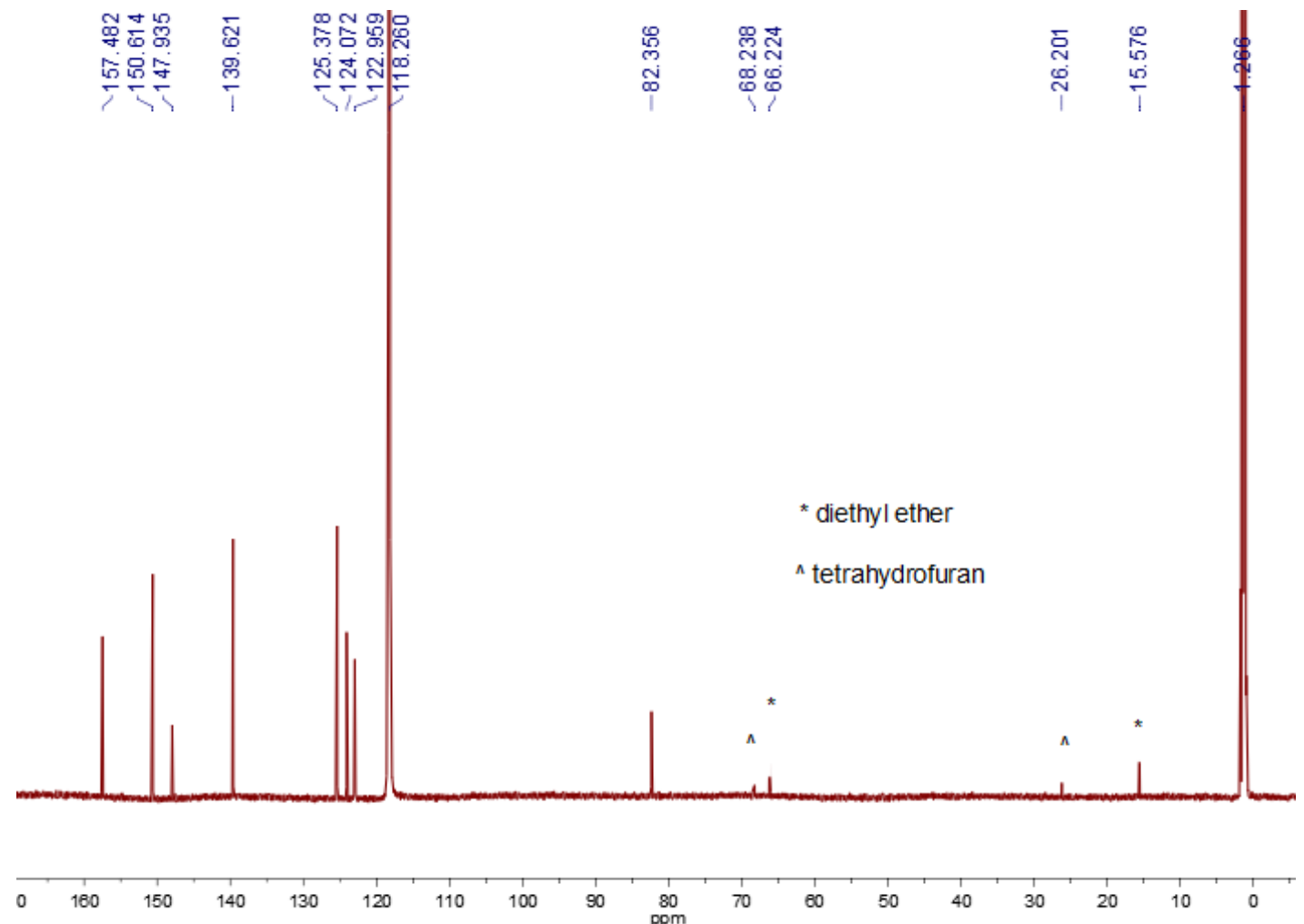

Figure S11: ${ }^{13} \mathrm{C}$ NMR $\left(214 \mathrm{MHz}, \mathrm{CD}_{3} \mathrm{CN}\right)$ spectrum of compound 1- $\mathrm{PF}_{6}$. 

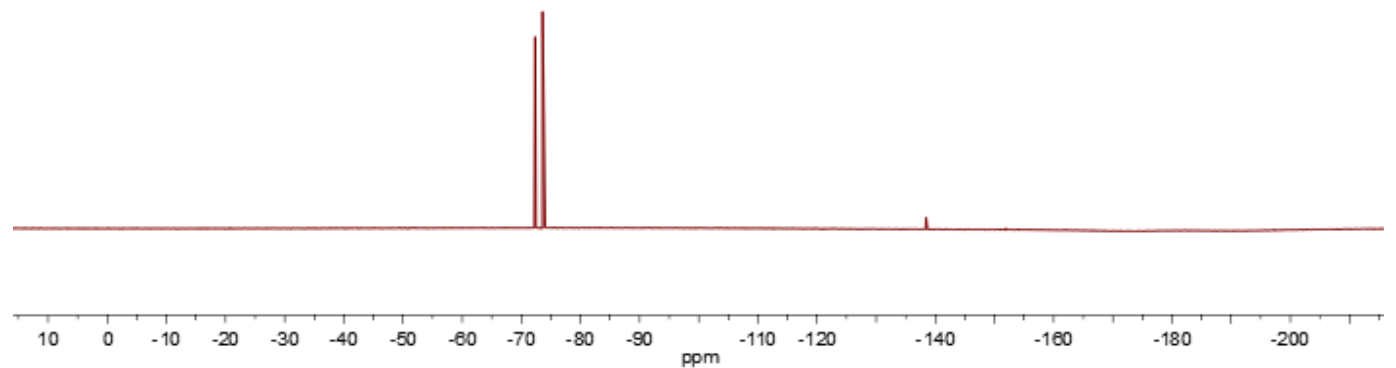

Figure S12: ${ }^{19} \mathrm{~F}$ NMR $\left(565 \mathrm{MHz}, \mathrm{CD}_{3} \mathrm{CN}\right.$ ) spectrum of compound 1- $\mathrm{PF}_{6}$.
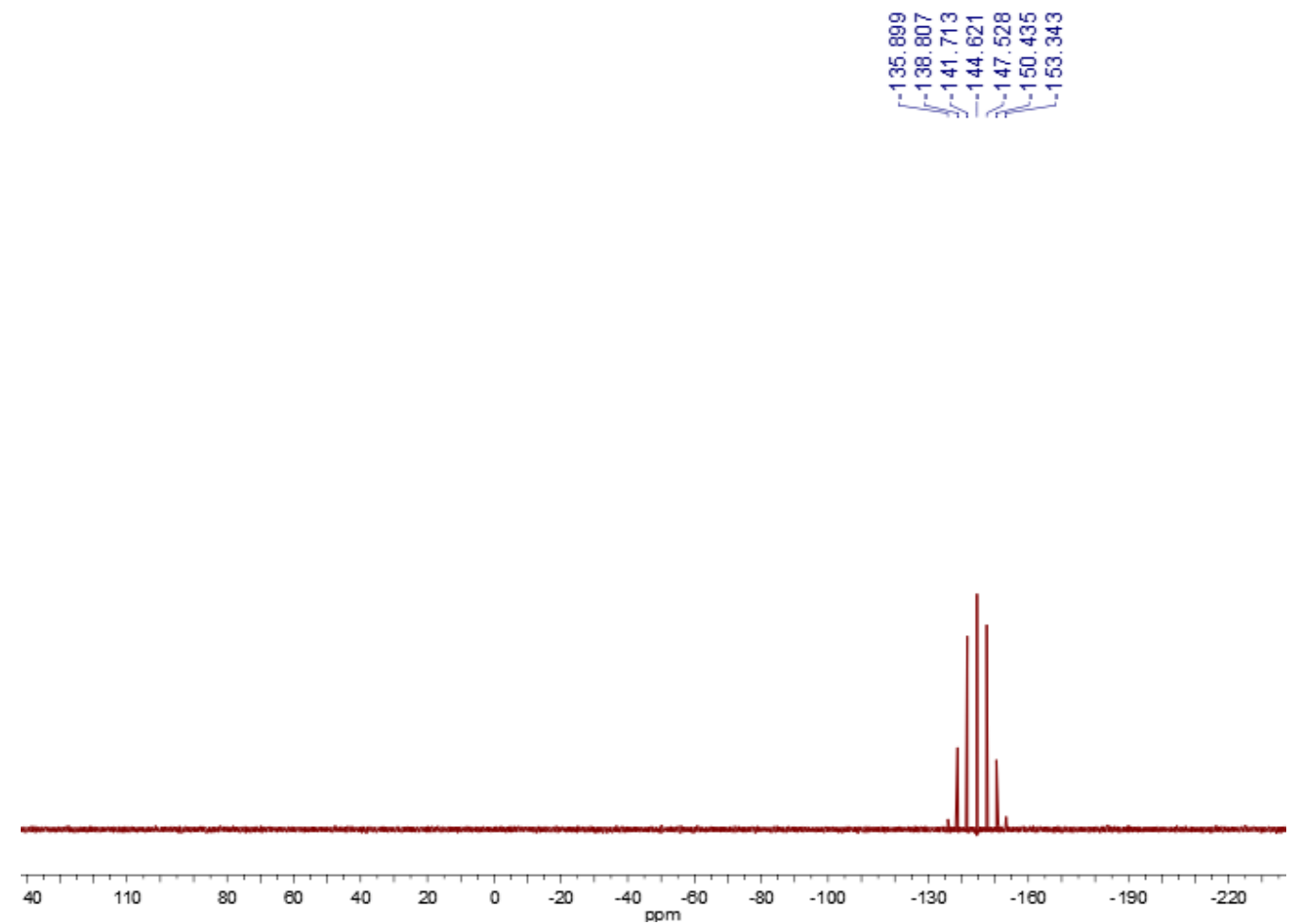

Figure S13: ${ }^{31} \mathrm{P}$ NMR (243 MHz, $\left.\mathrm{CD}_{3} \mathrm{CN}\right)$ spectrum of complex 1-PF6. 


\section{Synthesis of $\mathrm{LiSCH}_{2} \mathrm{CH}_{2} \mathrm{Ph}$}

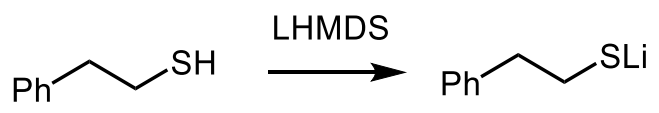

In the glove box, 2-phenylethanethiol ( $150 \mathrm{mg}, 1.09 \mathrm{mmol}, 1.0 \mathrm{eq}$ ) was dissolved in THF (ca. $5.0 \mathrm{~mL}$ ). To this solution was added a LiHMDS (191 mg, $1.14 \mathrm{mmol}, 1.05 \mathrm{eq})$ solution in THF (ca. $4.0 \mathrm{~mL}$ ). The mixture was stirred at room temperature for $1.0 \mathrm{~h}$. After the reaction, all volatiles were removed under vacuum and the crude white solid was washed with pentane $(\mathrm{ca} .10 \mathrm{~mL})$ three times to remove the excess amount of LiHMDS. The remaining white precipitate was dried under vacuum for $1.0 \mathrm{~h}$, affording $\mathrm{LiSCH}_{2} \mathrm{CH}_{2} \mathrm{Ph}$ as a white solid (150 mg, 96\%).

${ }^{1} \mathrm{H}$ NMR $(600 \mathrm{MHz}, \mathrm{THF}-d 8) \delta$ 7.25-7.12 (m, 4H), 7.03-7.01 (m, 1H), 2.79-2.77 (m, 2H), 2.67-2.64 (m, $2 \mathrm{H})$.

${ }^{13} \mathrm{C}$ NMR (151 MHz, THF- $\left.d 8\right) \delta 144.91$ (1C), 128.90 (2C), 128.33 (2C), 125.53 (1C), 46.24 (1C), 28.68 (1C).

Elemental analysis, Calcd for $\mathrm{C}_{8} \mathrm{H}_{9} \mathrm{LiS}: \quad \mathrm{C}, 66.65 ; \mathrm{H}, 6.29$. Found: C, 64.32; H, 6.11.

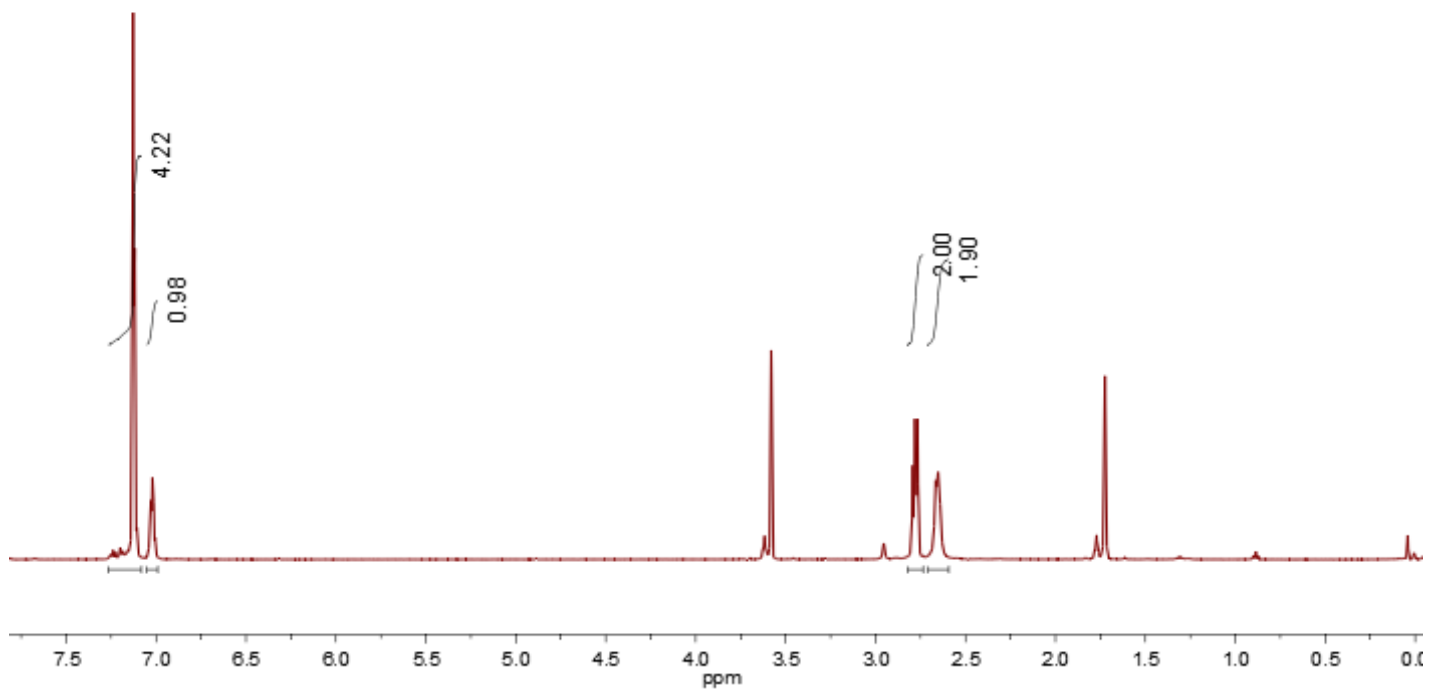

Figure S14: ${ }^{1} \mathrm{H}$ NMR $\left(600 \mathrm{MHz}, \mathrm{THF}-d_{8}\right)$ spectrum of compound $\mathrm{PhCH}_{2} \mathrm{CH}_{2} \mathrm{SLi}$. 


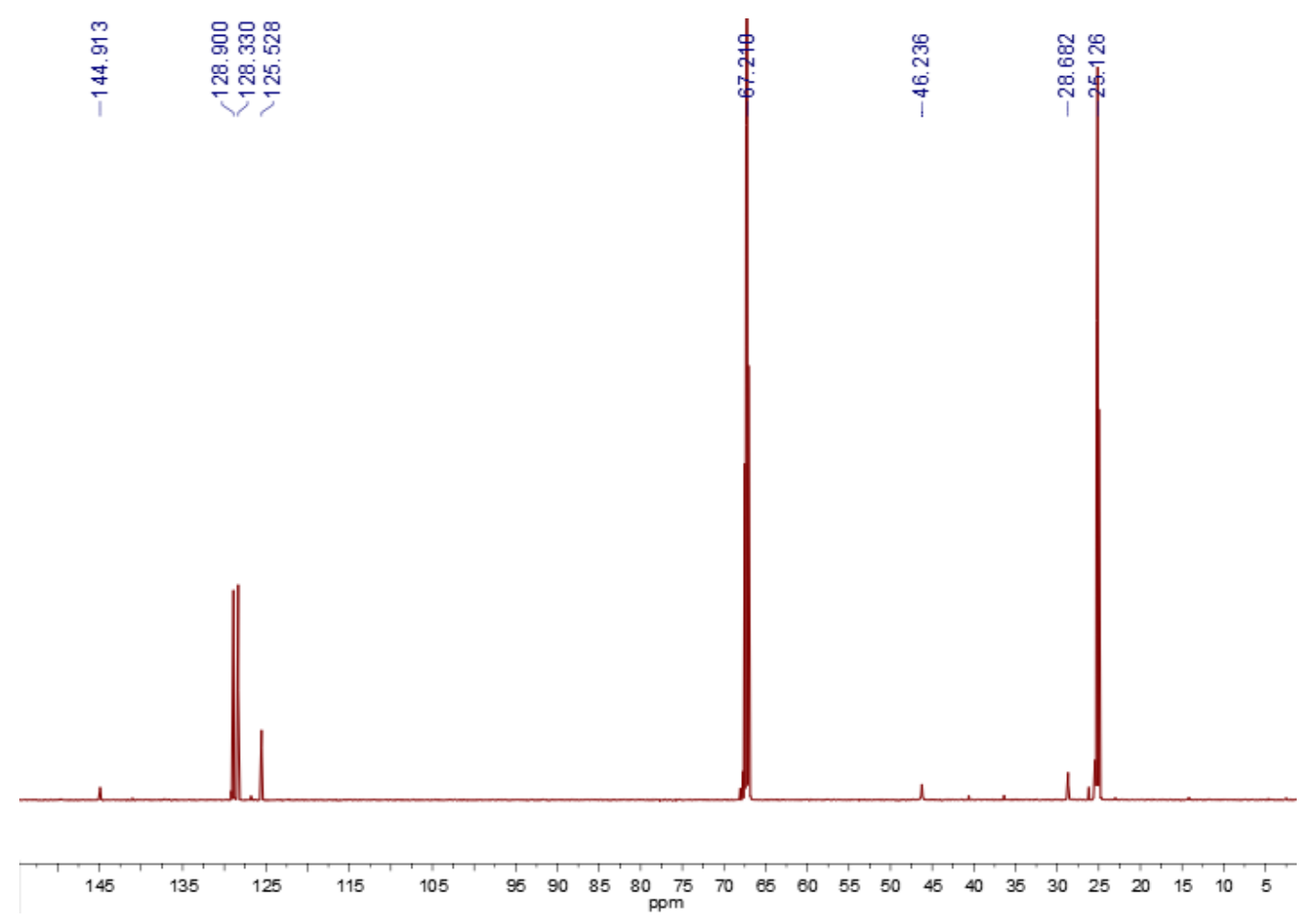

Figure S15: ${ }^{13} \mathrm{C}$ NMR $\left(151 \mathrm{MHz}\right.$, THF- $d_{8}$ ) spectrum of compound $\mathrm{PhCH}_{2} \mathrm{CH}_{2} \mathrm{SLi}$.

\section{Synthesis and characterization of 4-OTf}

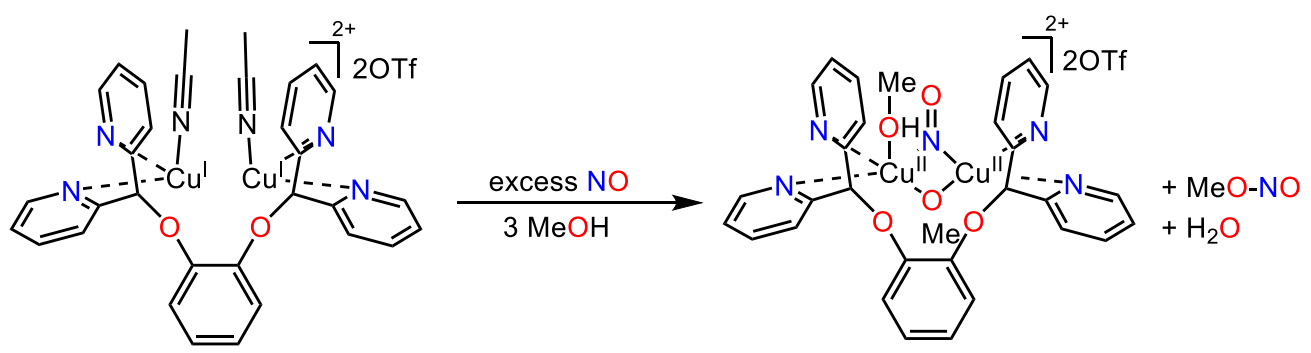

In the glovebox, 1-OTf $(40.0 \mathrm{mg}, 41.9 \mu \mathrm{mol})$ was dissolved in methanol $(5.0 \mathrm{~mL})$ and transferred into a 15 $\mathrm{mL}$ pressure flask. The pressure flask was sealed, transferred out of the glovebox, and cooled in a $-35^{\circ} \mathrm{C}$ cold bath. Under positive nitrogen flow, $\mathrm{NO} \cdot(10.0 \mathrm{~mL}, 0.417 \mathrm{mmol}, 10$ equiv. $)$ was injected into the solution. The flask was sealed and the resulting reaction mixture was stirred in the cold bath at $-35{ }^{\circ} \mathrm{C}$ overnight. The color of the solution gradually changed from yellow to green and finally to red. The pressure flask was then cooled in a dry ice/acetone bath for $c a .5$ min and then quickly transferred back to the glovebox. The solution was pipetted into a vial precooled in a $-35{ }^{\circ} \mathrm{C}$ freezer. Cold diethyl ether ( $\mathrm{ca} .8 .0$ $\mathrm{mL},-35^{\circ} \mathrm{C}$ ) and cold toluene ( $\mathrm{ca} .2 .0 \mathrm{~mL},-35^{\circ} \mathrm{C}$ ) was carefully layered on top of the methanol solution. The dark red crystals formed after several days were collected and dried under vacuum to give 4-OTf (27.0 $\mathrm{mg}, 67 \%$ yield) as a dark red solid. Elemental analysis of this compound was not performed due to its temperature sensitivity. Single crystal X-ray diffraction analysis was performed by picking single crystals of 4-OTf to a precooled glass slide with cold oil. 


\section{UV-Vis and NMR spectroscopy Studies Details}

\section{Reaction of 1-BAr ${ }_{4}$ with 2.0 eq. $\mathrm{PhCH}_{2} \mathrm{CH}_{2} \mathrm{SNO}$ in acetone}

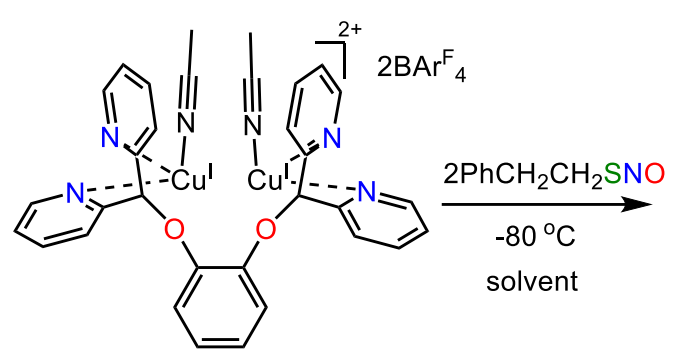

$1-\mathrm{BAr}_{4}$

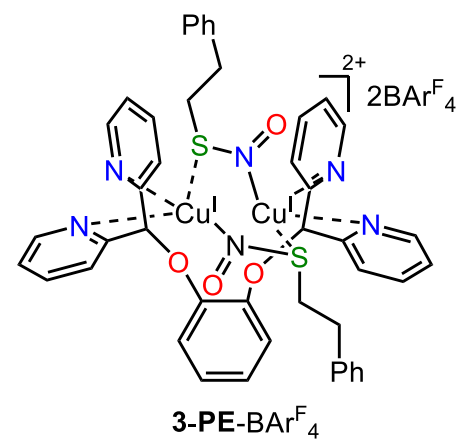

3-PE-BArF ${ }_{4}$

In the glovebox, an acetone solution of $1-\mathrm{BAr}_{4}{ }_{4}(5.4 \mathrm{mg}, 2.3 \mu \mathrm{mol}, 2.80 \mathrm{~mL})$ was placed in a quartz cuvette equipped with a rubber septum. The cuvette was sealed and transferred to the UV-Vis spectrometer precooled at $-80^{\circ} \mathrm{C}$. After the temperature stabilized, $\mathrm{PhCH}_{2} \mathrm{CH}_{2} \mathrm{SNO}(0.10 \mathrm{~mL}, 22.5 \mathrm{mM}$ in acetone, 2.3 $\mu \mathrm{mol}, 1.0$ equiv.) was injected to the solution, and the reaction progress was monitored by taking a UV-vis spectrum every 60 seconds. A new green species $\left(\lambda_{\max }=575 \mathrm{~nm}, \varepsilon=2400 \mathrm{M}^{-1} \mathrm{~cm}^{-1}\right.$ and $\lambda_{\max }=675 \mathrm{~nm}, \varepsilon$ $=1450 \mathrm{M}^{-1} \mathrm{~cm}^{-1}$ ) is generated (Figure S16). A second equivalent of $\mathrm{PhCH}_{2} \mathrm{CH}_{2} \mathrm{SNO}(0.10 \mathrm{~mL}, 22.5 \mathrm{mM}$ in acetone, $2.3 \mu \mathrm{mol}, 1.0$ equiv.) was injected to the above solution, and the reaction progress was monitored for another $36 \mathrm{~min}$. The stabilized UV-Vis spectra after the addition of one or two equivalents of $\mathrm{PhCH}_{2} \mathrm{CH}_{2} \mathrm{SNO}$ are shown in Figure S17. The new green species started to decay quickly when the cuvette was warmed up to $-50{ }^{\circ} \mathrm{C}$ in acetone.

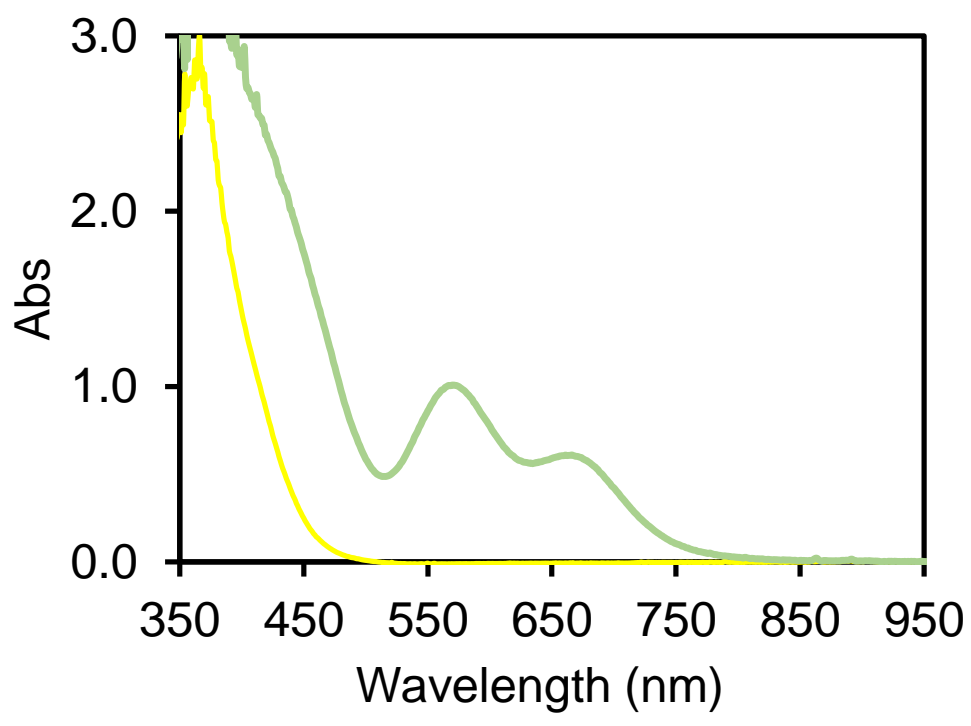

Figure S16. UV-Vis spectra of the reaction mixture of 1-B $\mathrm{Ar}_{4}{ }_{4}$ (yellow trace) and 1.0 eq. $\mathrm{PhCH}_{2} \mathrm{CH}_{2} \mathrm{SNO}$ (acetone, $-80^{\circ} \mathrm{C}$ ) (light green trace) 


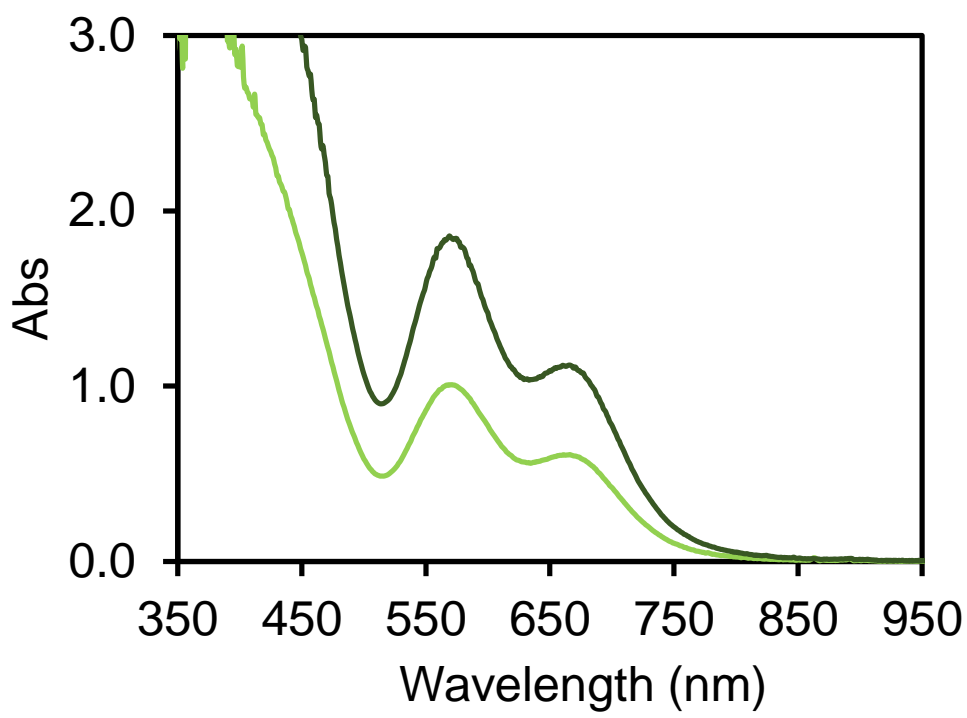

Figure S17. Comparison of UV-Vis spectra between the reaction mixture of $1-\mathrm{BAr}_{4}^{\mathrm{F}}$ and 1.0 eq. of $\mathrm{PhCH}_{2} \mathrm{CH}_{2} \mathrm{SNO}$ (light green trace) and 2.0 eq. of $\mathrm{PhCH}_{2} \mathrm{CH}_{2} \mathrm{SNO}$ (acetone, $-80{ }^{\circ} \mathrm{C}$, dark green trace).

\section{Reaction of 1-BAr ${ }_{4}{ }_{4}$ with 2.0 eq. $\mathrm{PhCH}_{2} \mathrm{CH}_{2} \mathrm{SNO}$ in THF}

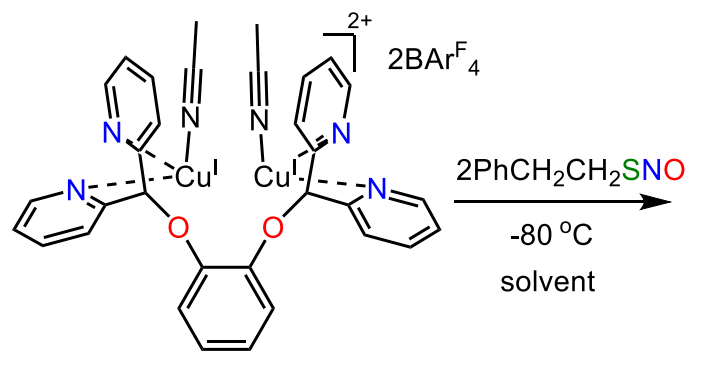

$1-\mathrm{BAr}_{4}{ }_{4}$

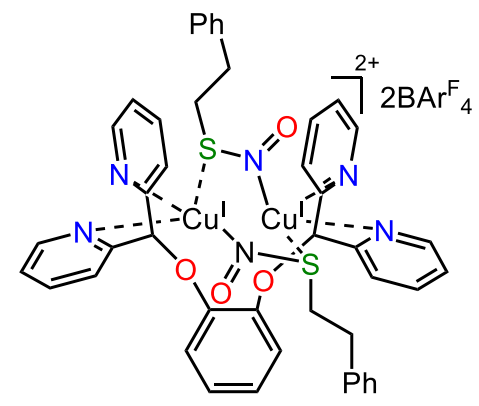

3-PE-BArF ${ }_{4}$

In the glovebox, a tetrahydrofuran solution of $1-\mathrm{BAr}_{4}{ }_{4}(5.4 \mathrm{mg}, 2.3 \mu \mathrm{mol}, 2.70 \mathrm{~mL})$ was placed in a quartz cuvette equipped with a rubber septum. The cuvette was sealed and transferred to the UV-Vis spectrometer precooled at $-80{ }^{\circ} \mathrm{C}$. After the temperature stabilized, $\mathrm{PhCH}_{2} \mathrm{CH}_{2} \mathrm{SNO}(0.10 \mathrm{~mL}, 22.5 \mathrm{mM}$ in THF, 2.3 $\mu \mathrm{mol}, 1.0$ equiv.) was injected to the solution, and the reaction progress was monitored by taking a UV-vis spectrum every 60 seconds. A new green species $\left(\lambda_{\max }=595 \mathrm{~nm}, \varepsilon=2500 \mathrm{M}^{-1} \mathrm{~cm}^{-1}\right.$ and $\lambda_{\max }=685 \mathrm{~nm}, \varepsilon$ $=1200 \mathrm{M}^{-1} \mathrm{~cm}^{-1}$ ) is generated (Figure S18). When a second equivalent of $\mathrm{PhCH}_{2} \mathrm{CH}_{2} \mathrm{SNO}(0.10 \mathrm{~mL}, 22.5$ $\mathrm{mM}$ in THF, $2.3 \mu \mathrm{mol}, 1.0$ equiv.) was injected to the above solution, the reaction progress was monitored for another $8.0 \mathrm{~min}$ (Figure S19). When a third equivalent of $\mathrm{PhCH}_{2} \mathrm{CH}_{2} \mathrm{SNO}(0.10 \mathrm{~mL}, 22.5 \mathrm{mM}$ in THF, $2.3 \mu \mathrm{mol}, 1.0$ equiv.) was injected into the cuvette, the $\mathrm{UV}$-Vis spectra only changed slightly due to dilution. The comparison of $\mathrm{UV}$-Vis spectra when 1.0 eq, 2.0 eq and 3.0 eq. of $\mathrm{PhCH}_{2} \mathrm{CH}_{2} \mathrm{SNO}$ are added is shown in Figure S20 and suggests that two equivalents of $\mathrm{PhCH}_{2} \mathrm{CH}_{2} \mathrm{SNO}$ can bind to the dicopper(I) complex. The new green species started to decay quickly when the cuvette was further warmed up to $-40{ }^{\circ} \mathrm{C}$ in THF. 


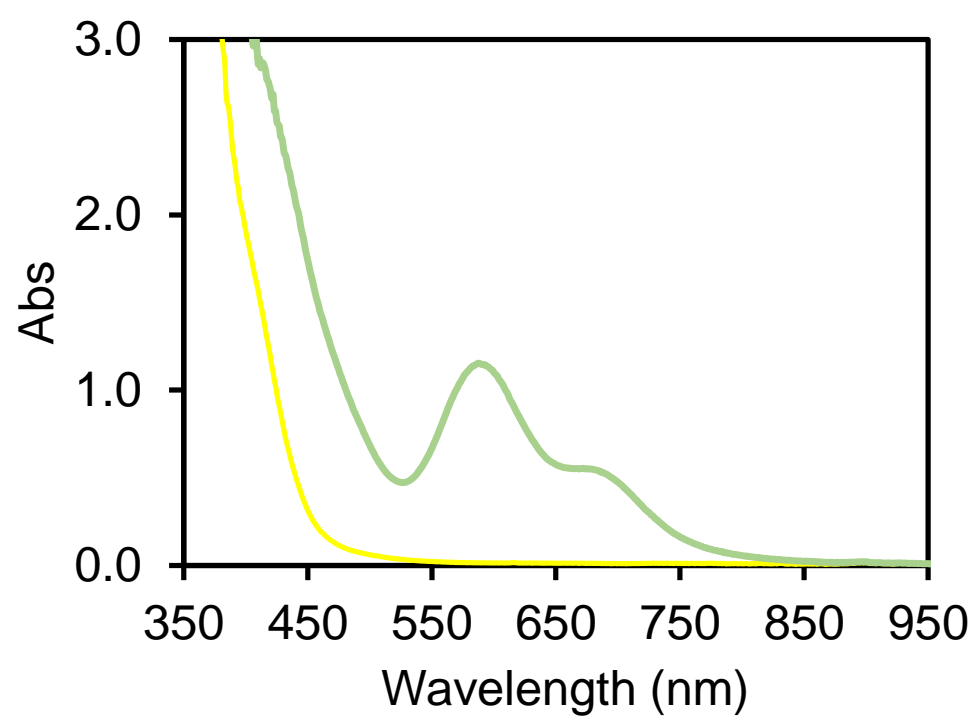

Figure S18. UV-Vis spectra of the reaction mixture of $1-\mathrm{BAr}_{4}{ }_{4}$ (yellow trace) and 1.0 eq. $\mathrm{PhCH}_{2} \mathrm{CH}_{2} \mathrm{SNO}$ (light green trace, THF, $-80^{\circ} \mathrm{C}$ )

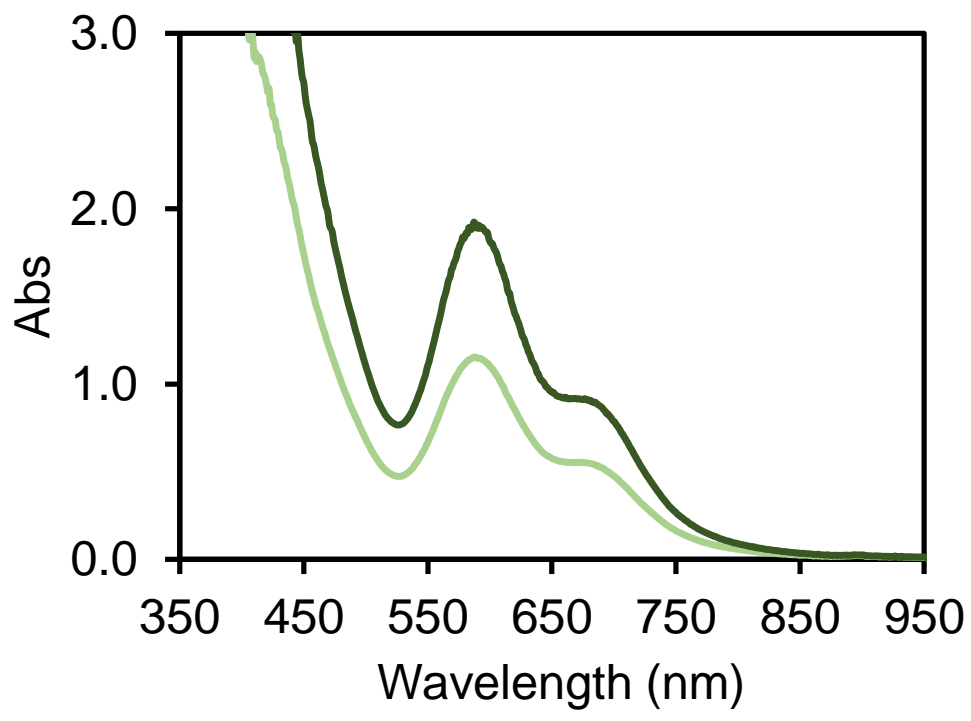

Figure S19. UV-Vis spectra of the reaction mixture of $1-\mathrm{BAr}_{4}{ }_{4}$ and 1.0 eq. $\mathrm{PhCH}_{2} \mathrm{CH}_{2} \mathrm{SNO}\left(\mathrm{THF},-80{ }^{\circ} \mathrm{C}\right.$, light green trace) followed by a second equivalent of $\mathrm{PhCH}_{2} \mathrm{CH}_{2} \mathrm{SNO}$ (dark green trace). 


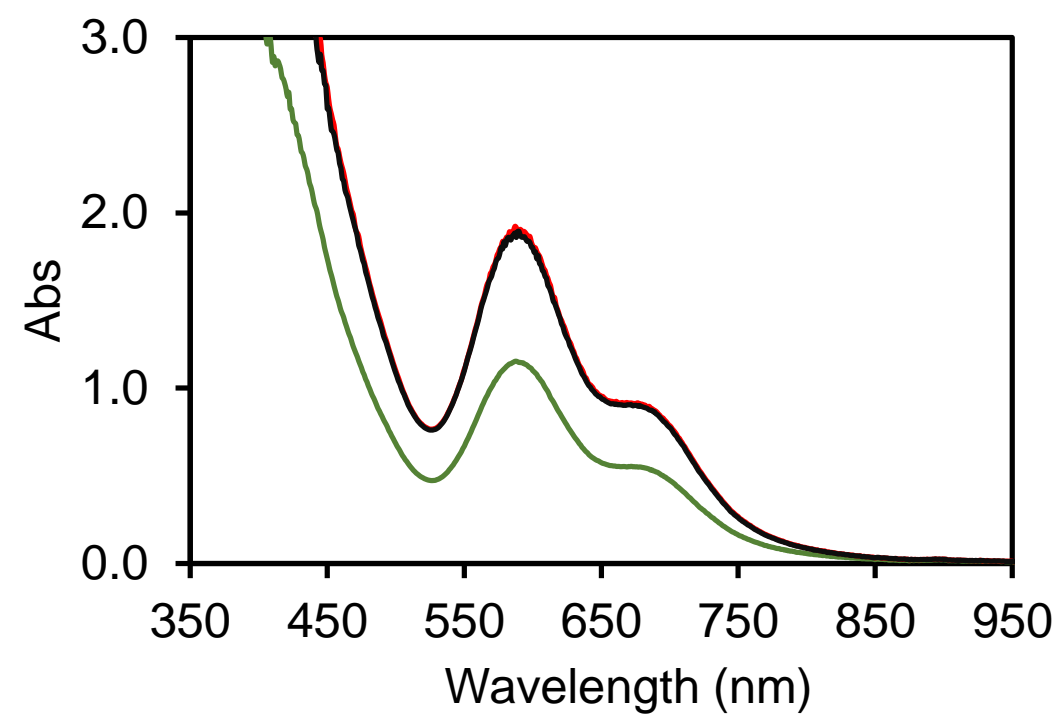

Figure S20. Comparison of UV-Vis spectra between the reaction mixture of 1-B $\mathrm{Ar}_{4}^{\mathrm{F}}$ and 1.0 eq. of $\mathrm{PhCH}_{2} \mathrm{CH}_{2} \mathrm{SNO}$ (green trace), 2.0 eq. of $\mathrm{PhCH}_{2} \mathrm{CH}_{2} \mathrm{SNO}$ (red trace) and 3.0 eq. of $\mathrm{PhCH}_{2} \mathrm{CH}_{2} \mathrm{SNO}$ (THF, $-80{ }^{\circ} \mathrm{C}$ ) (black trace).

\section{Reaction of 1-PF 6 with 2.0 eq. $\mathrm{PhCH}_{2} \mathrm{CH}_{2} \mathrm{SNO}$ in acetone}
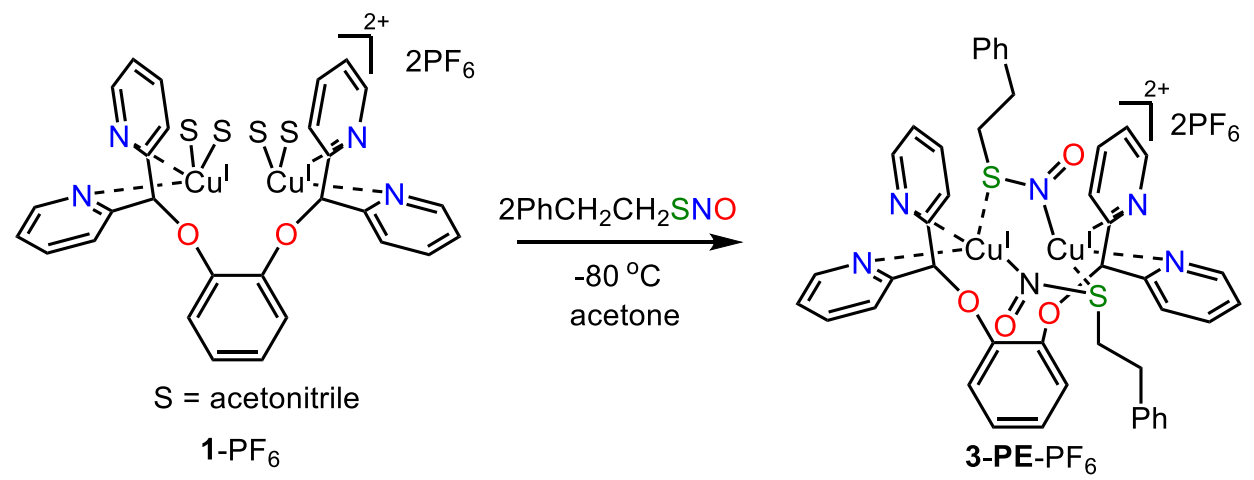

In the glovebox, an acetone solution of $1-\mathrm{PF}_{6}(2.3 \mathrm{mg}, 2.3 \mu \mathrm{mol}, 2.80 \mathrm{~mL})$ was placed in a quartz cuvette equipped with a rubber septum. The cuvette was sealed and transferred to the UV-Vis spectrometer precooled at $-80^{\circ} \mathrm{C}$. After the temperature stabilized, $\mathrm{PhCH}_{2} \mathrm{CH}_{2} \mathrm{SNO}(0.10 \mathrm{~mL}, 22.5 \mathrm{mM}$ in acetone, 2.3 $\mu \mathrm{mol}, 1.0$ equiv.) was injected to the solution, and the reaction progress was monitored by taking a UV-vis spectrum every 60 seconds. A new green species $\left(\lambda_{\max }=575 \mathrm{~nm}, \varepsilon=2400 \mathrm{M}^{-1} \mathrm{~cm}^{-1}\right.$ and $\lambda_{\max }=675 \mathrm{~nm}, \varepsilon$ $=1450 \mathrm{M}^{-1} \mathrm{~cm}^{-1}$ ) is generated (Figure S21). When a second equivalent of $\mathrm{PhCH}_{2} \mathrm{CH}_{2} \mathrm{SNO}(0.10 \mathrm{~mL}, 22.5$ $\mathrm{mM}$ in acetone, $2.3 \mu \mathrm{mol}, 1.0$ equiv.) was injected to the above solution, the reaction progress was monitored for another 10 min (Figure S22). The comparison of UV-Vis spectra between 1-BAr ${ }_{4}{ }_{4}$ with 2.0 eq. of $\mathrm{PhCH}_{2} \mathrm{CH}_{2} \mathrm{SNO}$ and 1-PF with 2.0 eq. of $\mathrm{PhCH}_{2} \mathrm{CH}_{2} \mathrm{SNO}$ is shown in Figure S23, which supports that counter anions $\left(\mathrm{BAr}_{4}\right.$ and $\left.\mathrm{PF}_{6}\right)$ have no impact on the binding of $S$-nitrosothiols at the dicopper(I) complex. The new green species with $\mathrm{PF}_{6}$ counter anion started to decay quickly when the cuvette was further warmed up to $-50{ }^{\circ} \mathrm{C}$ in acetone. 


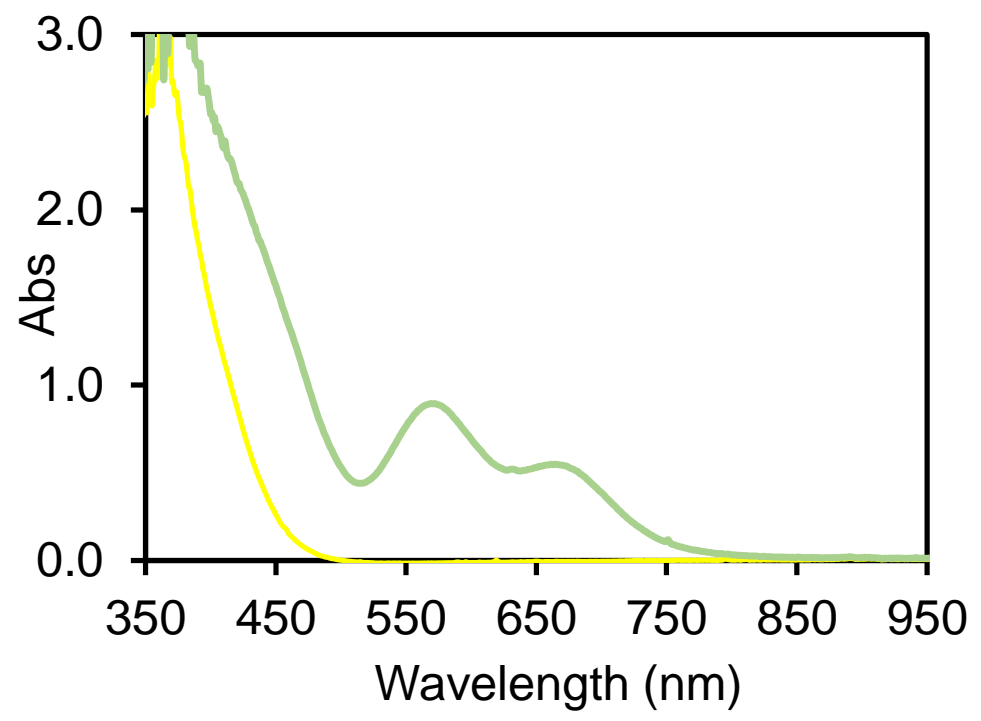

Figure S21. UV-Vis spectra of the reaction mixture of $1-\mathrm{PF}_{6}$ (yellow trace) and 1.0 eq. $\mathrm{PhCH}_{2} \mathrm{CH}_{2} \mathrm{SNO}$ (light green trace, acetone, $-80^{\circ} \mathrm{C}$ )

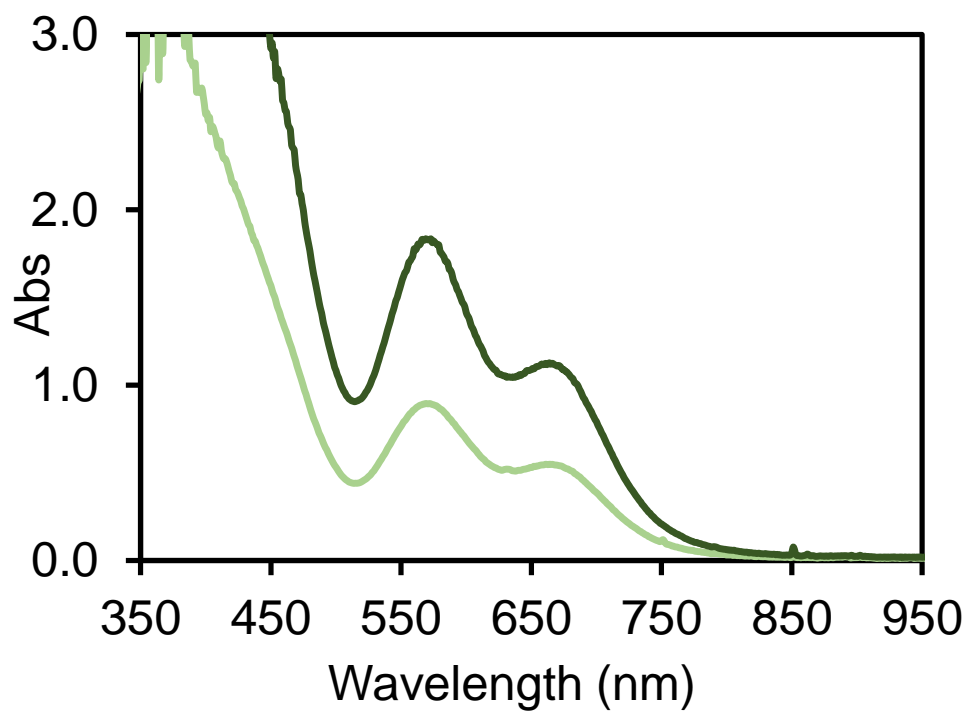

Figure S22. UV-Vis spectra of the reaction mixture of $1-\mathrm{PF}_{6}$ and 1.0 eq. $\mathrm{PhCH}_{2} \mathrm{CH}_{2} \mathrm{SNO}$ (light green trace, acetone, $-80{ }^{\circ} \mathrm{C}$ ) followed by a second equivalent of $\mathrm{PhCH}_{2} \mathrm{CH}_{2} \mathrm{SNO}$ (dark green trace). 


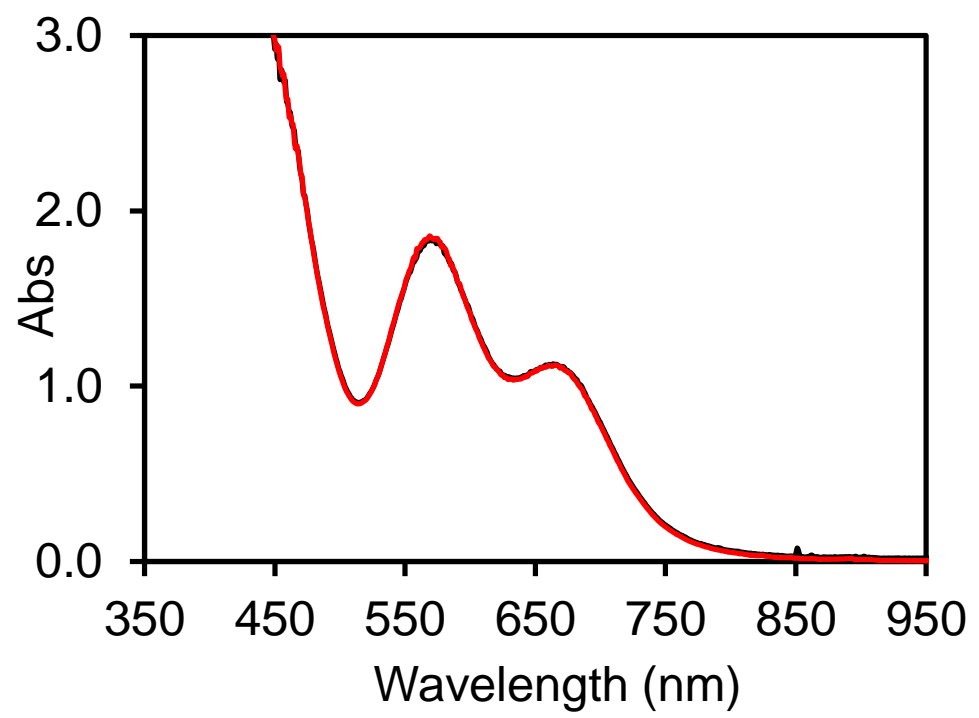

Figure S23. Comparison of UV-Vis spectra of the reaction mixture of 1- $\mathrm{PF}_{6}$ with 2.0 eq. $\mathrm{PhCH}_{2} \mathrm{CH}_{2} \mathrm{SNO}$ (black trace) and reaction mixture of $1-\mathrm{BAr}_{4}{ }_{4}$ with 2.0 eq. $\mathrm{PhCH}_{2} \mathrm{CH}_{2} \mathrm{SNO}$ (red trace, acetone, $-80{ }^{\circ} \mathrm{C}$ ).

\section{Reaction of 1-PF 6 with 2.0 eq. $\mathrm{PhCH}_{2} \mathrm{CH}_{2} \mathrm{SNO}$ in DCM}

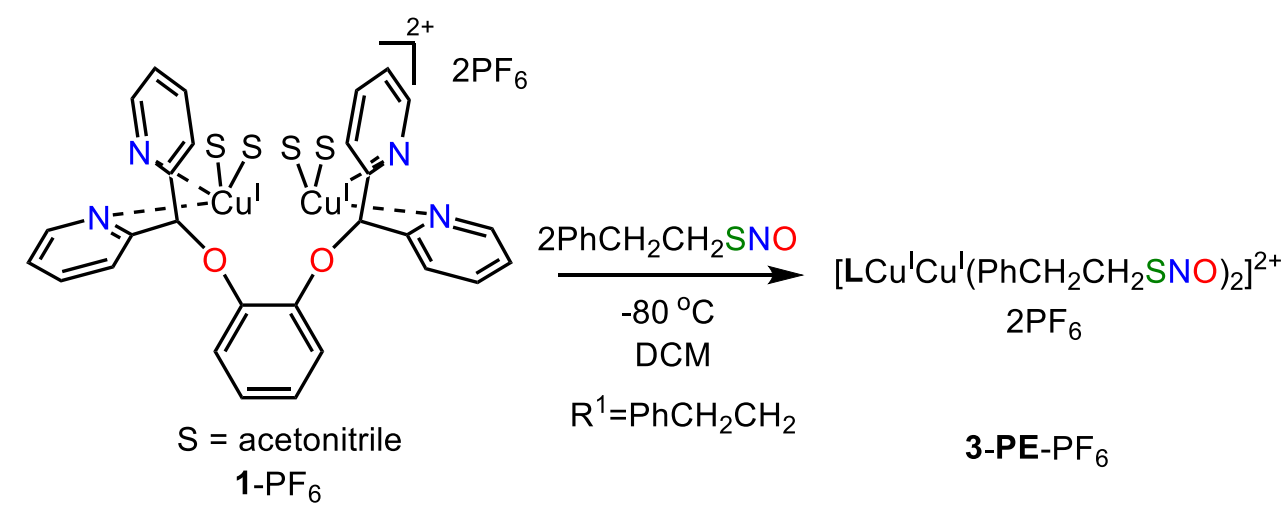

In the glovebox, a dichloromethane solution of $1-\mathrm{PF}_{6}(2.3 \mathrm{mg}, 2.3 \mu \mathrm{mol}, 2.80 \mathrm{~mL})$ was placed in a quartz cuvette equipped with a rubber septum. The cuvette was sealed and transferred to the UV-Vis spectrometer precooled at $-80{ }^{\circ} \mathrm{C}$. After the temperature stabilized, $\mathrm{PhCH}_{2} \mathrm{CH}_{2} \mathrm{SNO}(0.10 \mathrm{~mL}, 22.5 \mathrm{mM}$ in DCM, 2.3 $\mu \mathrm{mol}, 1.0$ equiv.) was injected to the solution, and the reaction progress was monitored by taking a UV-vis spectrum every 60 seconds. A new green species $\left(\lambda_{\max }=450 \mathrm{~nm}, \varepsilon=5600 \mathrm{M}^{-1} \mathrm{~cm}^{-1}, \lambda_{\max }=545 \mathrm{~nm}, \varepsilon=2100\right.$ $\mathrm{M}^{-1} \mathrm{~cm}^{-1}$ and $\lambda_{\max }=675 \mathrm{~nm}, \varepsilon=2500 \mathrm{M}^{-1} \mathrm{~cm}^{-1}$ ) is generated (Figure S24). When a second equivalent of $\mathrm{PhCH}_{2} \mathrm{CH}_{2} \mathrm{SNO}(0.10 \mathrm{~mL}, 22.5 \mathrm{mM}$ in DCM, $2.3 \mu \mathrm{mol}, 1.0$ equiv.) was injected to the above solution, the reaction progress was monitored for another $6.0 \mathrm{~min}$. The comparison of UV-Vis spectra when 1.0 eq and 2.0 eq. of $\mathrm{PhCH}_{2} \mathrm{CH}_{2} \mathrm{SNO}$ are added is shown in Figure $\mathrm{S} 25$, which resembles that observed in acetone. These reaction conditions were also employed for the in-situ IR experiments to investigate the $\mathrm{N}=\mathrm{O}$ stretching frequency. The new green species with $\mathrm{PF}_{6}$ counter anion started to decay quickly when the cuvette was further warmed to higher than $-60^{\circ} \mathrm{C}$ in DCM. 


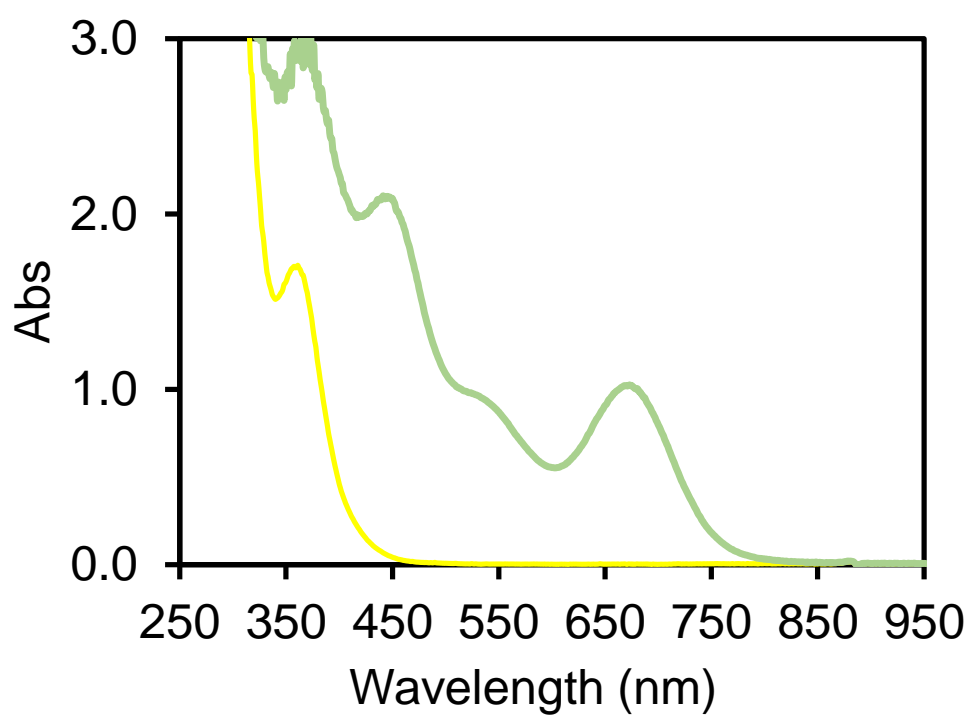

Figure S24. UV-Vis spectra of the reaction mixture of $1-\mathrm{PF}_{6}$ (yellow trace) and 1.0 eq. $\mathrm{PhCH}_{2} \mathrm{CH}_{2} \mathrm{SNO}$ (light green trace, $\mathrm{DCM},-80{ }^{\circ} \mathrm{C}$ )

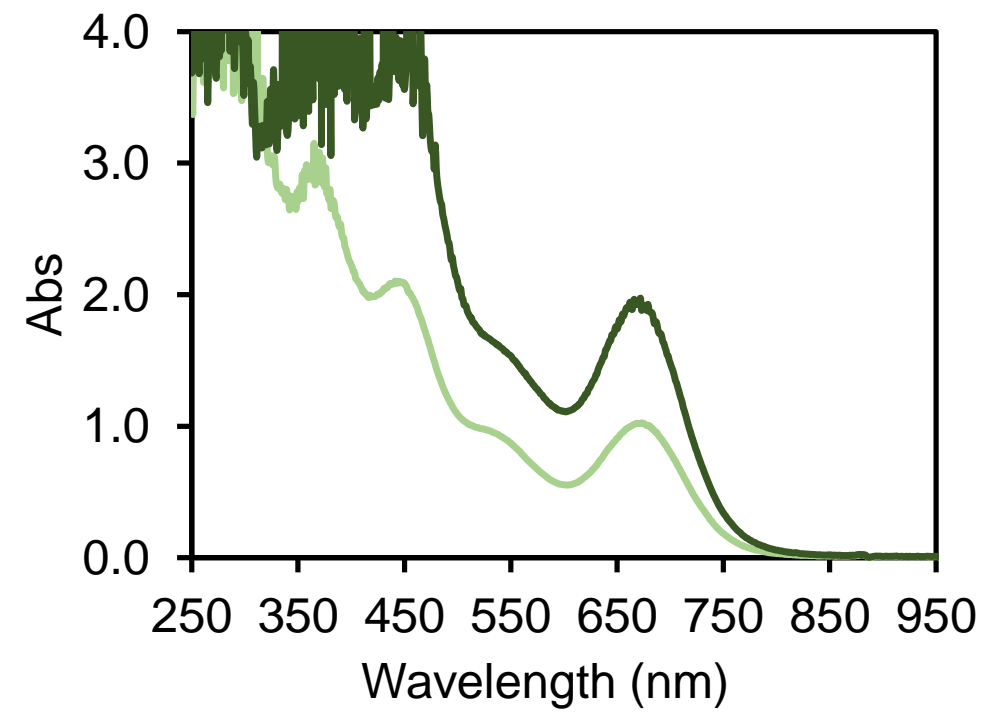

Figure S25. UV-Vis spectra of the reaction mixture of $1-\mathrm{PF}_{6}$ and 1.0 eq. $\mathrm{PhCH}_{2} \mathrm{CH}_{2} \mathrm{SNO}$ (light green trace, DCM, $-80^{\circ} \mathrm{C}$ ) followed by a second equivalent of $\mathrm{PhCH}_{2} \mathrm{CH}_{2} \mathrm{SNO}$ (dark green trace). 


\section{Reaction of 2-BAr ${ }_{4}$ with two equivalents of $\mathrm{PhCH}_{2} \mathrm{CH}_{2} \mathrm{SH}$ directly}

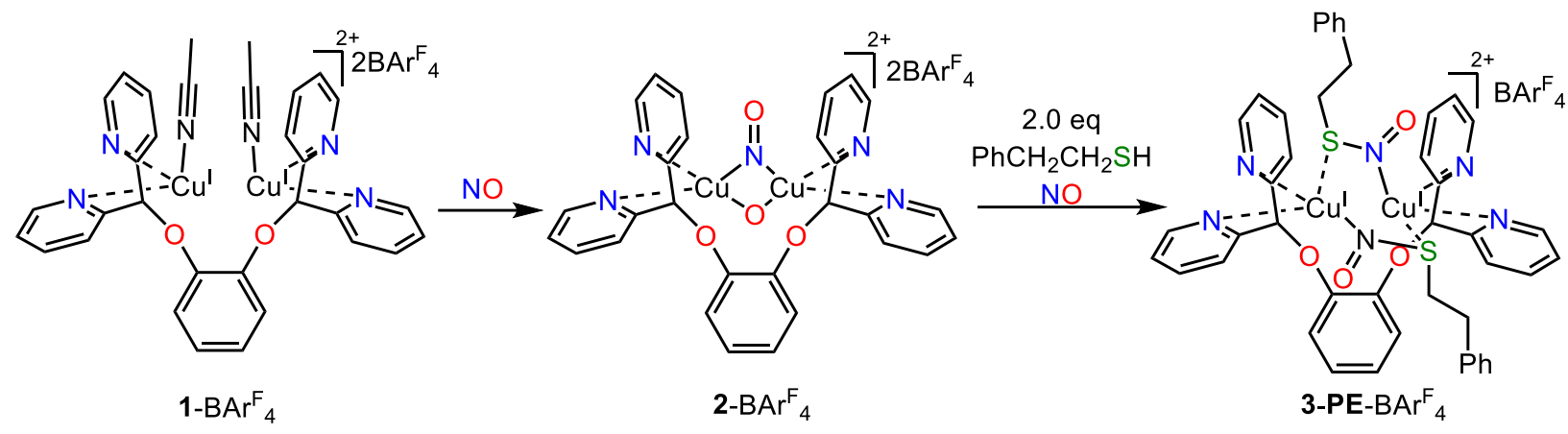

In the glovebox, an acetone solution of $1-\mathrm{BAr}_{4}{ }_{4}(5.4 \mathrm{mg}, 2.3 \mu \mathrm{mol}, 2.8 \mathrm{~mL})$ was placed in a Schlenk quartz cuvette. The cuvette was sealed and transferred to the UV-Vis spectrometer precooled at $-50{ }^{\circ} \mathrm{C}$. After the temperature stabilized, NO $(2.0 \mathrm{~mL}, 83.3 \mu \mathrm{mol}, 37 \mathrm{eq}$. $)$ was injected into the solution and the reaction progress was monitored by taking a UV-Vis spectrum every 60 seconds until the dicopper $\mu$-oxo, $\mu$-nitrosyl $\left(2-\mathrm{BAr}_{4}{ }_{4}\right)$ band at $520 \mathrm{~nm}$ reached an absorbance of $c a$. 1.95 and stabilized. The cuvette was cooled to $-80{ }^{\circ} \mathrm{C}$ and stabilized before $\mathrm{PhCH}_{2} \mathrm{CH}_{2} \mathrm{SH}(0.20 \mathrm{~mL}, 22.5 \mathrm{mM}$ in acetone, $4.6 \mu \mathrm{mol}, 2.0$ equiv.) was injected to the above solution. The reaction progress was monitored by taking a UV-vis spectrum every 60 seconds. After ca. $30 \mathrm{~min}$, the Schlenk cuvette was sealed and transferred to a $-70{ }^{\circ} \mathrm{C}$ cold bath and stored for $24 \mathrm{~h}$. The cuvette was transferred back to the UV-Vis spectrometer precooled at $-80{ }^{\circ} \mathrm{C}$ and a UV-Vis spectrum was taken every 60 seconds. A new green species $\left(\lambda_{\max }=575 \mathrm{~nm}, \varepsilon=2500 \mathrm{M}^{-1} \mathrm{~cm}^{-1}\right.$ and $\lambda_{\max }=$ $675 \mathrm{~nm}, \varepsilon=1500 \mathrm{M}^{-1} \mathrm{~cm}^{-1}$ ) is generated (Figure S26). The comparison of the UV-Vis spectra generated from 1-BAr ${ }_{4}$ with two equivalents of $\mathrm{PhCH}_{2} \mathrm{CH}_{2} \mathrm{SNO}$ (red trace) and 2-BAr${ }_{4}$ with two equivalents of 2phenyl ethanethiol (black trace) in the presence of excess amount of NO is shown in Figure S27, which strongly suggests that the two methods produce the same proposed dicopper(I,I) di-S-nitrosothiols product.

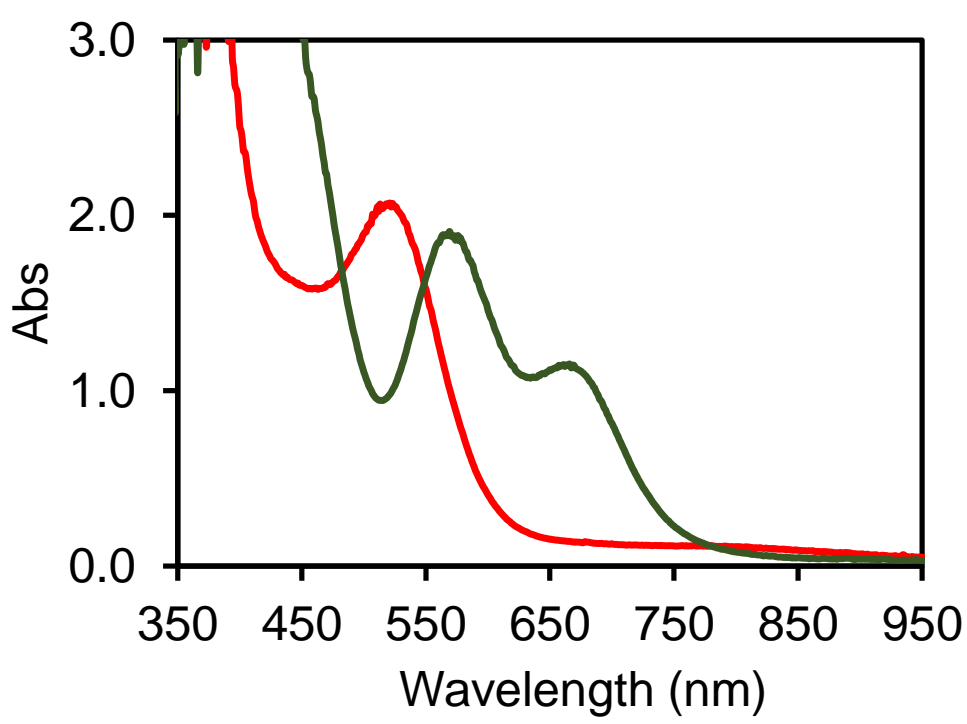

Figure S26. UV-Vis spectra of the reaction mixture of $2-\mathrm{BAr}_{4}{ }_{4}$ (red trace) and 2.0 eq. $\mathrm{PhCH}_{2} \mathrm{CH}_{2} \mathrm{SH}$ (green trace, $-80^{\circ} \mathrm{C}$, after reaction at $-70^{\circ} \mathrm{C}$ for $24 \mathrm{~h}$ ) 


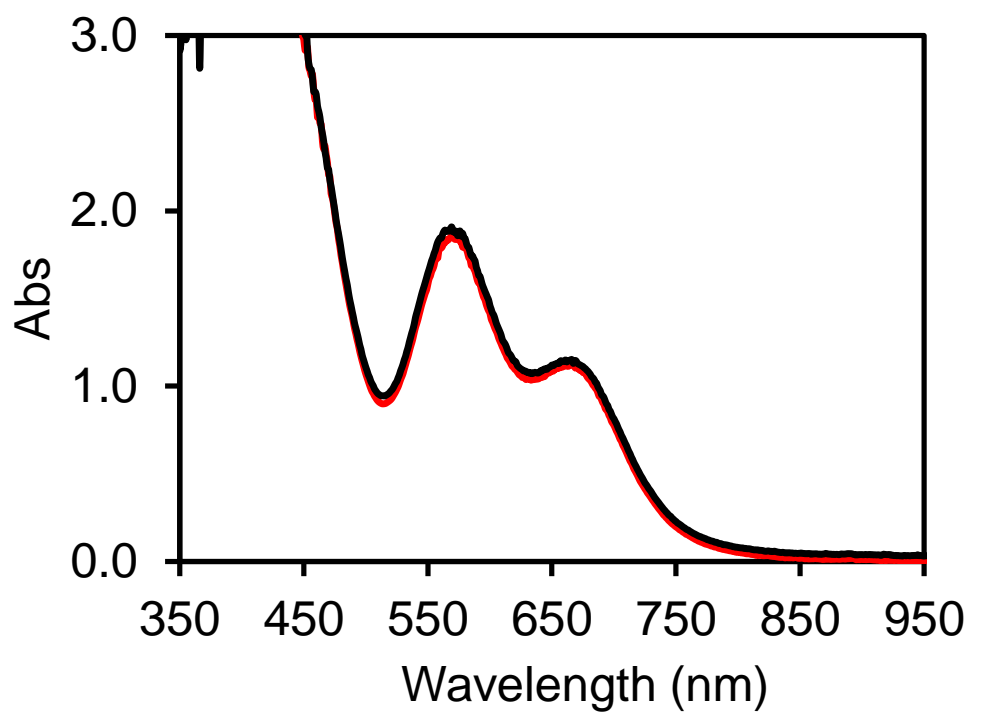

Figure S27. The comparison of UV-Vis spectra of the reaction mixture of 2-BAr${ }_{4}$ with 2.0 eq. $\mathrm{PhCH}_{2} \mathrm{CH}_{2} \mathrm{SH}$ in the presence of excess amount of $\mathrm{NO}$ (black trace) and that of 1-BArF ${ }_{4}$ with 2.0 eq. of $\mathrm{PhCH}_{2} \mathrm{CH}_{2} \mathrm{SNO}$ (red trace) in acetone at $-80{ }^{\circ} \mathrm{C}$.

\section{Reaction of 2-BAr ${ }_{4}$ with two equivalents of $\mathrm{PhCH}_{2} \mathrm{CH}_{2} \mathrm{SH}$ sequentially}

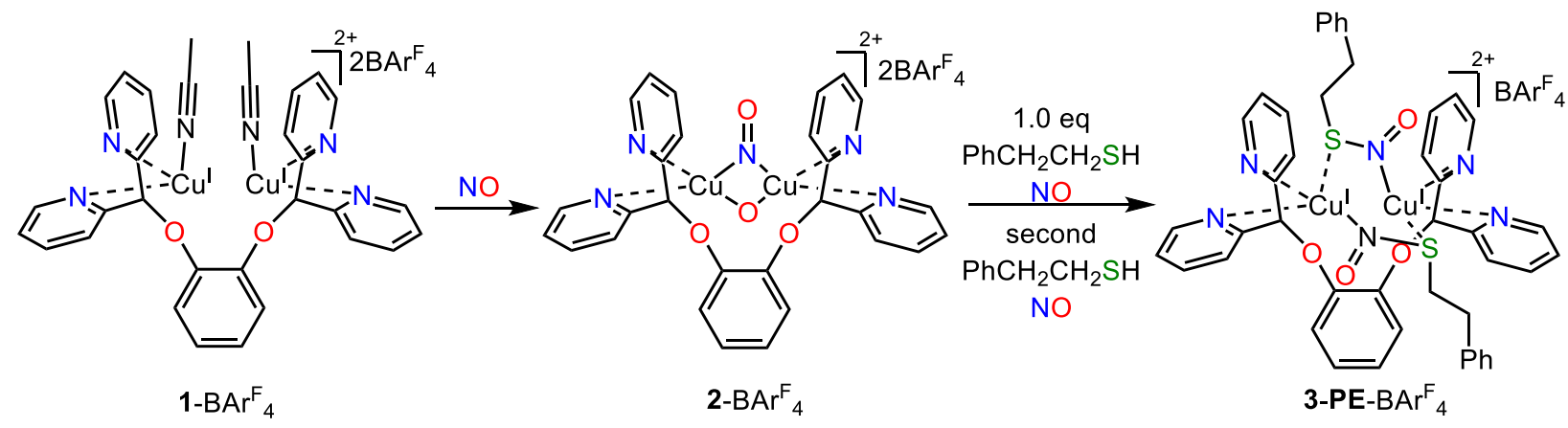

In the glovebox, an acetone solution of $1-\mathrm{BAr}_{4}{ }_{4}(5.4 \mathrm{mg}, 2.3 \mu \mathrm{mol}, 2.8 \mathrm{~mL})$ was placed in a Schlenk quartz cuvette. The cuvette was sealed and transferred to the UV-Vis spectrometer precooled at $-50{ }^{\circ} \mathrm{C}$. After the temperature stabilized, NO $(2.0 \mathrm{~mL}, 83.3 \mu \mathrm{mol}, 37 \mathrm{eq}$.) was injected into the solution and the reaction progress was monitored by taking a UV-Vis spectrum every 60 seconds until the dicopper $\mu$-oxo, $\mu$-nitrosyl $\left(2-\mathrm{BAr}_{4}\right)$ band at $520 \mathrm{~nm}$ reached an absorbance of $c a .1 .95$ and stabilized. The cuvette was cooled to $-80{ }^{\circ} \mathrm{C}$ and stabilized before $\mathrm{PhCH}_{2} \mathrm{CH}_{2} \mathrm{SH}(0.10 \mathrm{~mL}, 22.5 \mathrm{mM}$ in acetone, $2.3 \mu \mathrm{mol}, 1.0$ equiv. $)$ was injected to the above solution. The reaction progress was monitored by taking a UV-vis spectrum every 60 seconds. After ca. $30 \mathrm{~min}$, the Schlenk cuvette was sealed and transferred to a $-70{ }^{\circ} \mathrm{C}$ cold bath and stored for $7 \mathrm{~h}$. The cuvette was transferred back to the UV-Vis spectrometer precooled at $-80{ }^{\circ} \mathrm{C}$ and a UV-Vis spectrum was taken every 60 seconds. A brown solution is generated (Figure $\mathrm{S} 28) . \mathrm{PhCH}_{2} \mathrm{CH}_{2} \mathrm{SH}(0.10$ $\mathrm{mL}, 22.5 \mathrm{mM}$ in acetone, $2.3 \mu \mathrm{mol}, 1.0$ equiv.) was injected to the above solution under positive nitrogen flow and the Schlenk cuvette was sealed and transferred to a $-70{ }^{\circ} \mathrm{C}$ cold bath and stored for $30 \mathrm{~h}$. The 
cuvette was transferred back to the UV-Vis spectrometer precooled at $-80{ }^{\circ} \mathrm{C}$ and a UV-Vis spectrum was taken every 60 seconds. A new green species $\left(\lambda_{\max }=575 \mathrm{~nm}, \varepsilon=2200 \mathrm{M}^{-1} \mathrm{~cm}^{-1}\right.$ and $\lambda_{\max }=675 \mathrm{~nm}, \varepsilon=$ $1300 \mathrm{M}^{-1} \mathrm{~cm}^{-1}$ ) is generated (Figure S29). The comparison of the UV-Vis spectra generated from $2-\mathrm{BAr}_{4}{ }_{4}$ with direct two equivalents of $\mathrm{PhCH}_{2} \mathrm{CH}_{2} \mathrm{SH}$ (green trace) and sequential addition of two equivalents of 2phenylethanethiol (blue trace) in the presence of excess amount of NO is shown in Figure S29, which suggests that the two addition methods produce the same proposed dicopper(I,I) di-S-nitrosothiols product and the reaction with direct addition of 2-phenylethanethiol is a little cleaner.

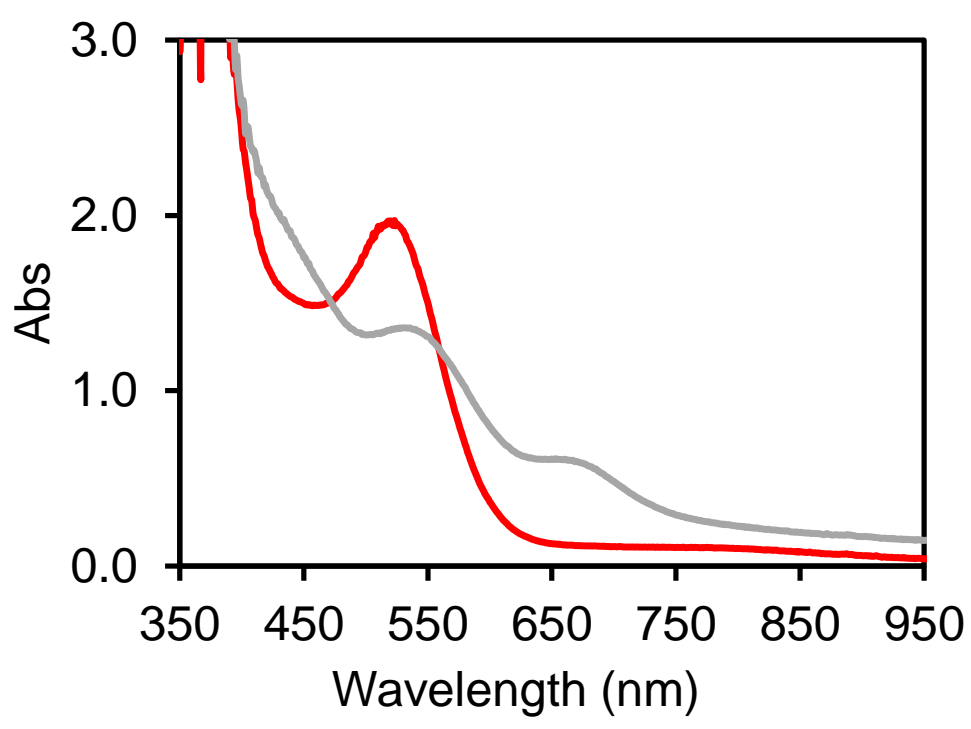

Figure S28. UV-Vis spectra of the reaction mixture of $2-\mathrm{BAr}_{4}^{\mathrm{F}}$ (red trace) and 1.0 eq. $\mathrm{PhCH}_{2} \mathrm{CH}_{2} \mathrm{SH}$ (gray trace, $-80{ }^{\circ} \mathrm{C}$, after reaction at $-70{ }^{\circ} \mathrm{C}$ for $7 \mathrm{~h}$ )

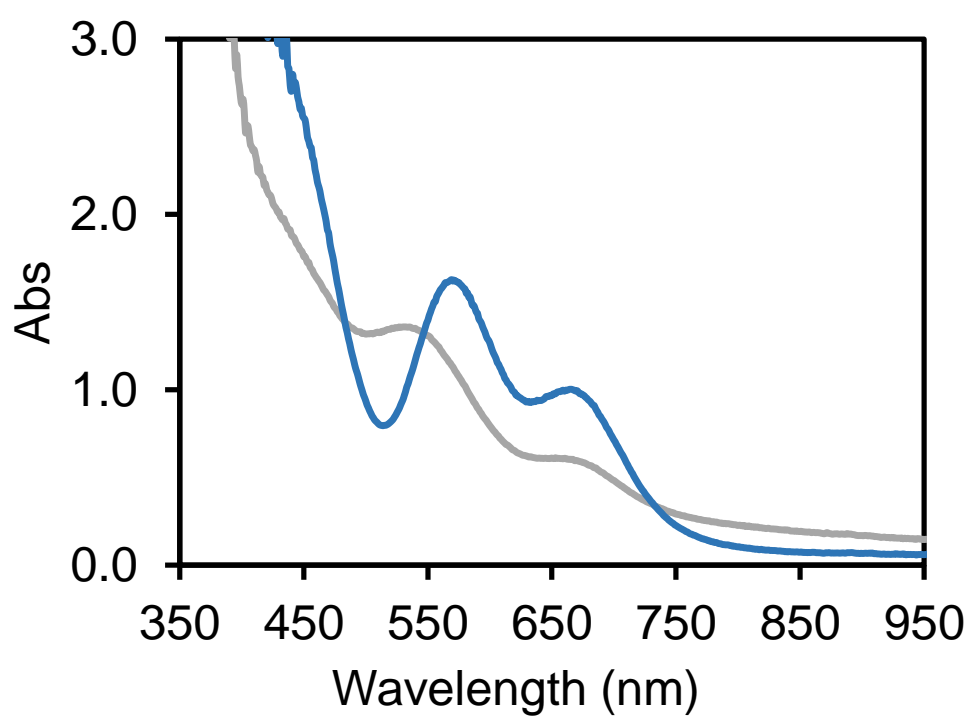

Figure S29. UV-Vis spectra of the reaction mixture of $2-\mathrm{BAr}^{\mathrm{F}}$ (red trace) with 1.0 eq. $\mathrm{PhCH}_{2} \mathrm{CH}_{2} \mathrm{SH}$ (gray trace, $-80^{\circ} \mathrm{C}$, after reaction at $-70{ }^{\circ} \mathrm{C}$ for $7 \mathrm{~h}$ ) and a second equivalent of $\mathrm{PhCH}_{2} \mathrm{CH}_{2} \mathrm{SH}$ (blue trace, $-80{ }^{\circ} \mathrm{C}$, after reaction at $-70{ }^{\circ} \mathrm{C}$ for $30 \mathrm{~h}$ ) 


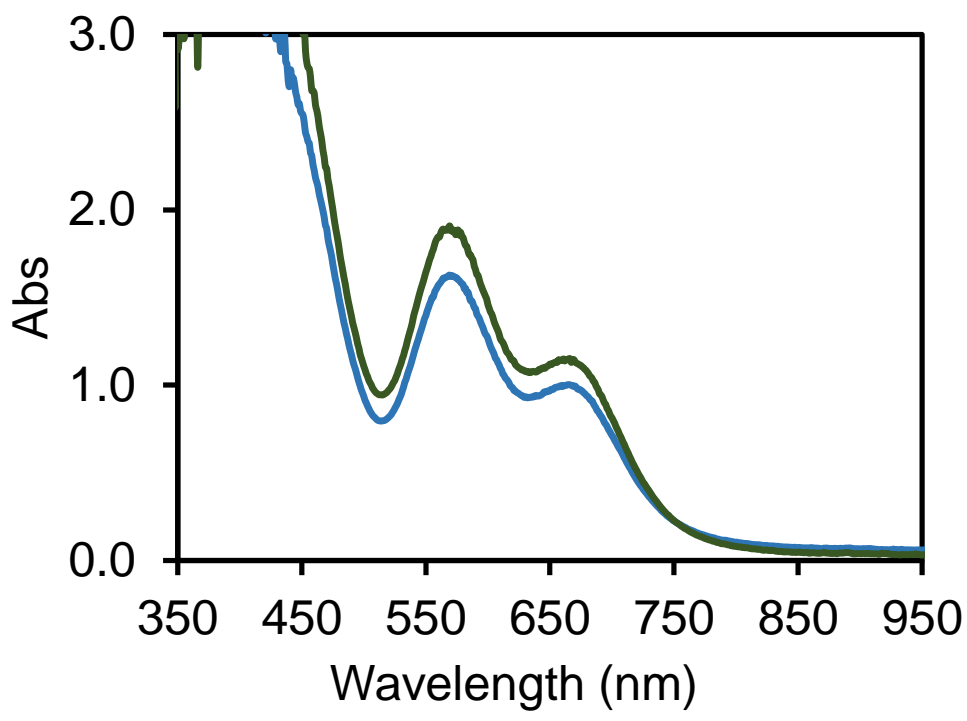

Figure S30. UV-Vis spectra of the reaction mixture of 2-B $\mathrm{Ar}^{\mathrm{F}}$ (red trace) with direct 2.0 eq. $\mathrm{PhCH}_{2} \mathrm{CH}_{2} \mathrm{SH}$ (green trace, $-80{ }^{\circ} \mathrm{C}$, after reaction at $-70{ }^{\circ} \mathrm{C}$ for $24 \mathrm{~h}$ ) and sequential 2.0 eq. of $\mathrm{PhCH}_{2} \mathrm{CH}_{2} \mathrm{SH}$ (blue trace, $-80{ }^{\circ} \mathrm{C}$, after reaction at $-70{ }^{\circ} \mathrm{C}$ for $30 \mathrm{~h}$ )

\section{Reaction of 1-BAr ${ }_{4}{ }_{4}$ with 2.0 eq. $\mathrm{PhCH}_{2} \mathrm{CH}_{2} \mathrm{SNO}$ in propionitrile}

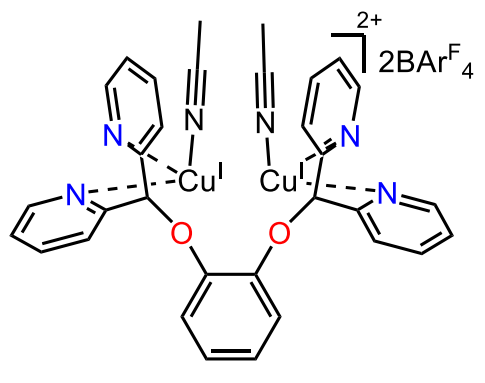

$1-\mathrm{BArF}_{4}$

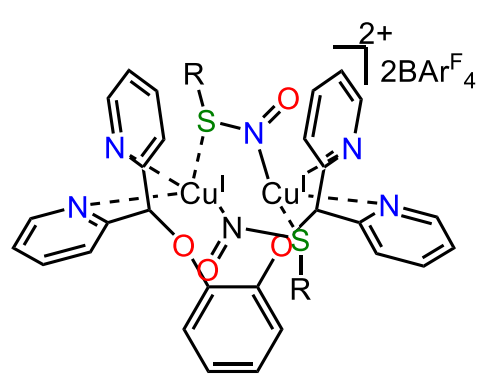

3-PE-BArF ${ }_{4}$

In the glovebox, a propionitrile solution of $1-\mathrm{BAr}^{\mathrm{F}}{ }_{4}(5.4 \mathrm{mg}, 2.3 \mu \mathrm{mol}, 2.80 \mathrm{~mL})$ was placed in a quartz cuvette equipped with a rubber septum. The cuvette was sealed and transferred to the UV-Vis spectrometer precooled at $-80^{\circ} \mathrm{C}$. After the temperature stabilized, $\mathrm{PhCH}_{2} \mathrm{CH}_{2} \mathrm{SNO}(0.20 \mathrm{~mL}, 22.5 \mathrm{mM}$ in propionitrile, $4.6 \mu \mathrm{mol}, 2.0$ equiv.) was injected to the solution, and the reaction progress was monitored by taking a UVvis spectrum every 60 seconds. In contrast to reactions in other solvents, such as acetone (Figure S17), THF (Figure S19), or DCM (Figure S25), no new bands around $675 \mathrm{~nm}$ and $580 \mathrm{~nm}$ were observed (Figure S31). Only free $\mathrm{PhCH}_{2} \mathrm{CH}_{2} \mathrm{SNO}$ signals are observed near $550 \mathrm{~nm}$. The free $\mathrm{PhCH}_{2} \mathrm{CH}_{2} \mathrm{SNO}$ was stable when the temperature was increased to $-60{ }^{\circ} \mathrm{C}, 0{ }^{\circ} \mathrm{C}$ and $20{ }^{\circ} \mathrm{C}$ (Figure S32). This experiment suggests that in the presence of excess propionitrile, the binding of S-nitrosothiol to the dicopper(I,I) center is suppressed. 


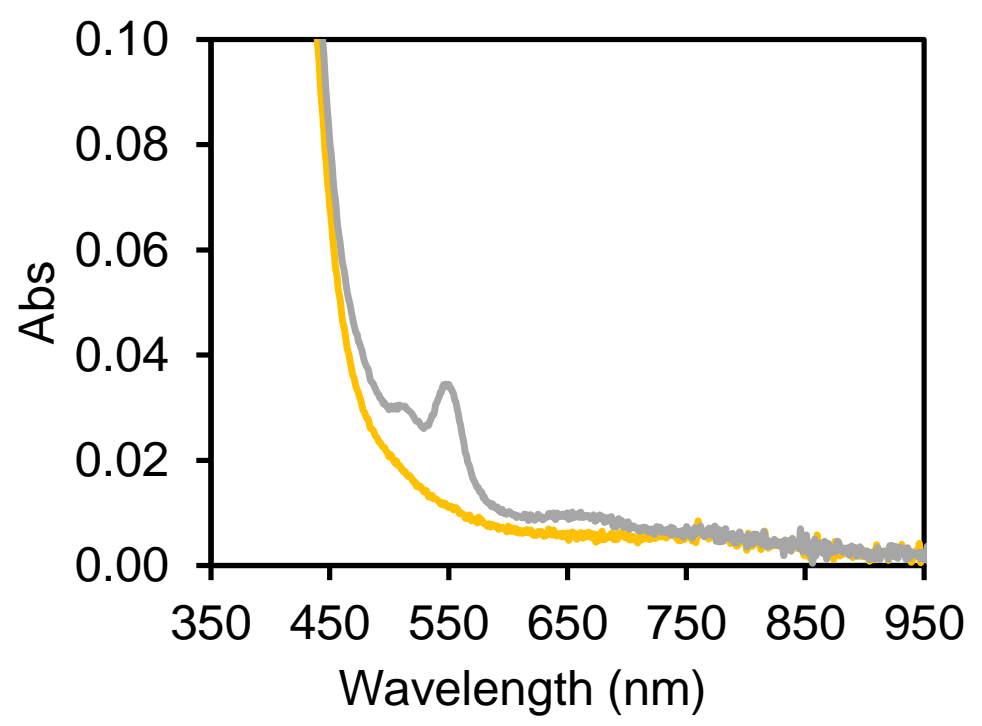

Figure S31. UV-Vis spectra of the reaction mixture of 1-BAr ${ }_{4}$ (yellow trace) and 2.0 eq. $\mathrm{PhCH}_{2} \mathrm{CH}_{2} \mathrm{SNO}$ (gray trace, propionitrile, $-80{ }^{\circ} \mathrm{C}$ )

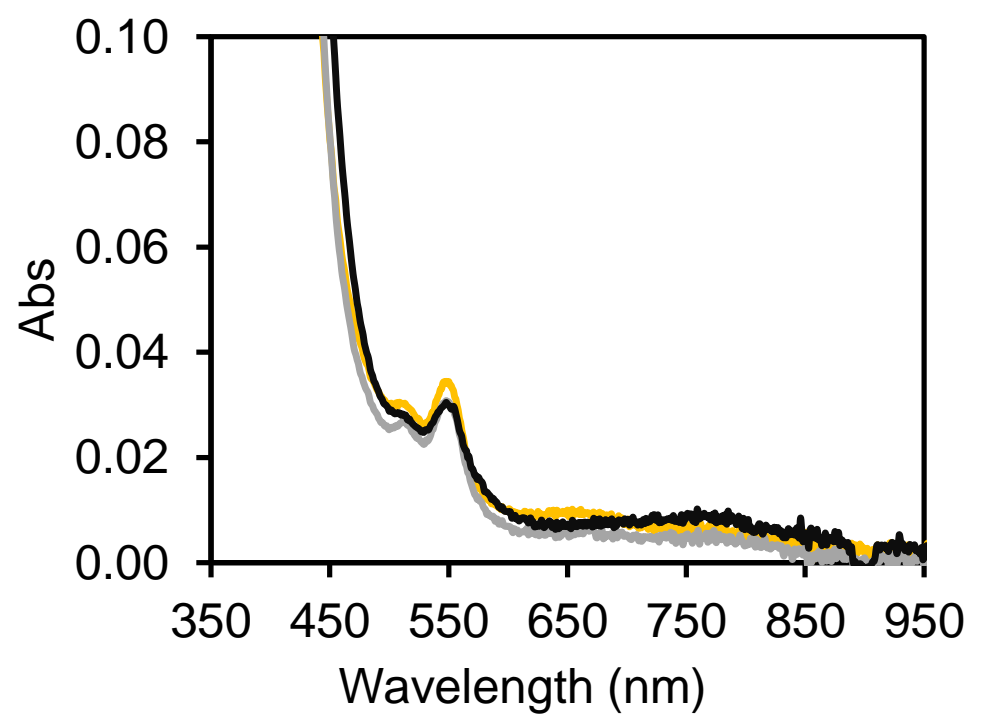

Figure S32. UV-Vis spectra of the reaction mixture of $1-\mathrm{BAr}_{4}{ }_{4}$ and 2.0 eq. $\mathrm{PhCH}_{2} \mathrm{CH}_{2} \mathrm{SNO}$ in propionitrile (yellow trace at $-80{ }^{\circ} \mathrm{C}$, gray trace at $-60{ }^{\circ} \mathrm{C}$ and black trace at $20{ }^{\circ} \mathrm{C}$ ) 


\section{Reaction of excess propionitrile with proposed dicopper(I,I) di-S-nitrosothiol}

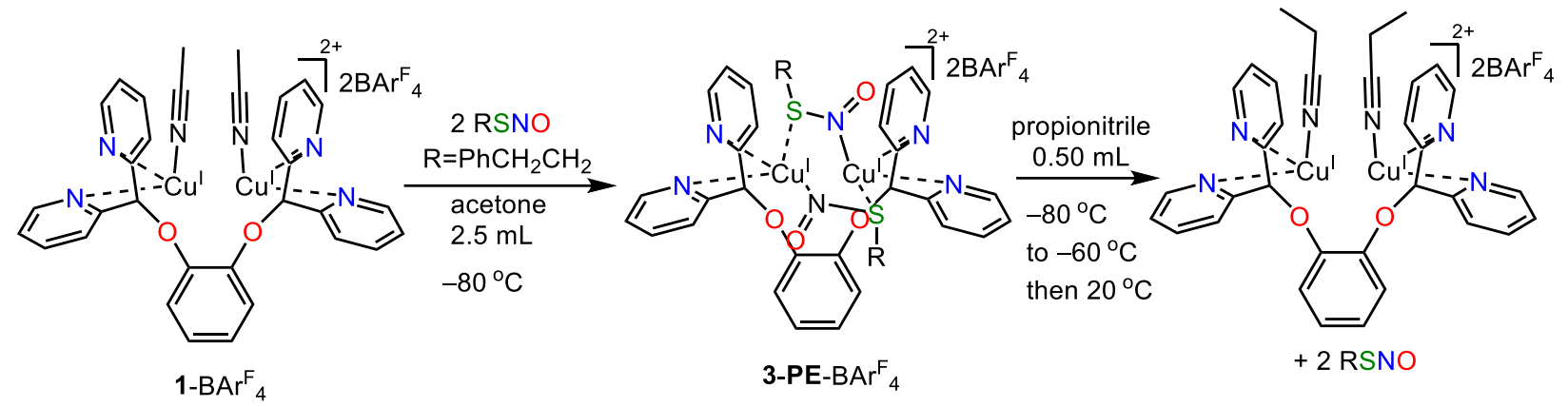

In the glovebox, an acetone solution of $1-\mathrm{BAr}_{4}{ }_{4}(5.4 \mathrm{mg}, 2.3 \mu \mathrm{mol}, 2.30 \mathrm{~mL})$ was placed in a quartz cuvette equipped with a rubber septum. The cuvette was sealed and transferred to the UV-Vis spectrometer precooled at $-80{ }^{\circ} \mathrm{C}$. After the temperature stabilized, $\mathrm{PhCH}_{2} \mathrm{CH}_{2} \mathrm{SNO}(0.20 \mathrm{~mL}, 22.5 \mathrm{mM}$ in acetone, 4.6 $\mu \mathrm{mol}, 2.0$ equiv.) was injected to the solution, and the reaction progress was monitored by taking a UV-vis spectrum every 60 seconds. The proposed dicopper(I,I) di-S-nitrosothiol species $\left(\lambda_{\max }=575 \mathrm{~nm}, \varepsilon=2400\right.$ $\mathrm{M}^{-1} \mathrm{~cm}^{-1}$ and $\lambda_{\max }=675 \mathrm{~nm}, \varepsilon=1450 \mathrm{M}^{-1} \mathrm{~cm}^{-1}$ ) is generated. After the spectrum stabilized, propionitrile $(0.50 \mathrm{~mL}, 7.2 \mathrm{mmol}, 3100 \mathrm{eq}$.) was injected to the solution and the reaction was monitored by taking a UVVis spectrum every 60 seconds. After the spectrum stabilized at $-80^{\circ} \mathrm{C}$ (Figure S33), the temperature was increased to $-70{ }^{\circ} \mathrm{C}$, and the reaction was monitored by UV-vis until stabilized again. These procedures were repeated as the temperature was increased to $-60{ }^{\circ} \mathrm{C},-50{ }^{\circ} \mathrm{C}$ and $-40{ }^{\circ} \mathrm{C}$ (Figure S34). When the spectrum stabilized at $-40{ }^{\circ} \mathrm{C}$, the reaction was warmed up to $20^{\circ} \mathrm{C}$ and free S-nitrosothiol $\mathrm{PhCH}_{2} \mathrm{CH}_{2} \mathrm{SNO}$ signals around $550 \mathrm{~nm}$ were observed (black trace compared with free $\mathrm{PhCH}_{2} \mathrm{CH}_{2} \mathrm{SNO}$ gray trace in Figure S35). This experiment strongly suggests that an excess amount of propionitrile can displace $S$-nitrosothiol bound to dicopper(I,I). Inspired by this result, we attempt to quantify the amount of $\mathrm{PhCH}_{2} \mathrm{CH}_{2} \mathrm{SNO}$ that is formed from the reaction of dicopper $\mu$-oxo, $\mu$-nitrosyl 2-B $\mathrm{Ar}_{4}{ }_{4}$ and free thiol $\mathrm{PhCH}_{2} \mathrm{CH}_{2} \mathrm{SH}$ in the presence of excess nitric oxide using ${ }^{1} \mathrm{H}$ NMR.

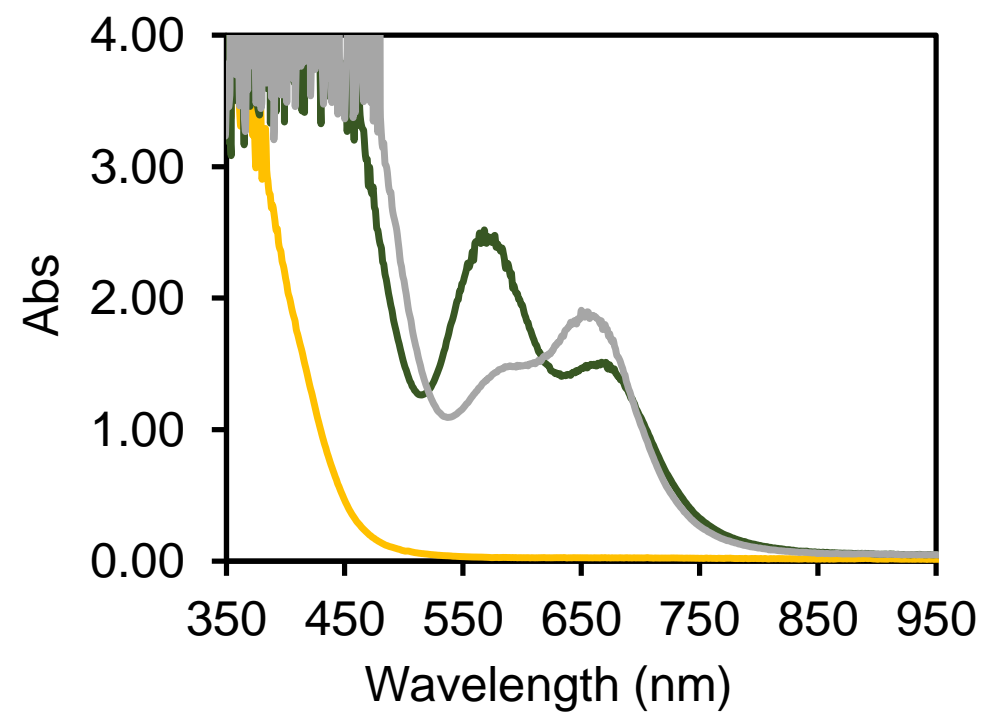

Figure S33. UV-Vis spectra of the reaction mixture of $1-\mathrm{BAr}_{4}{ }_{4}$ (yellow trace) and 2.0 eq. $\mathrm{PhCH}_{2} \mathrm{CH}_{2} \mathrm{SNO}$ (dark green trace) followed by addition of propionitrile (gray trace) at $-80{ }^{\circ} \mathrm{C}$. 


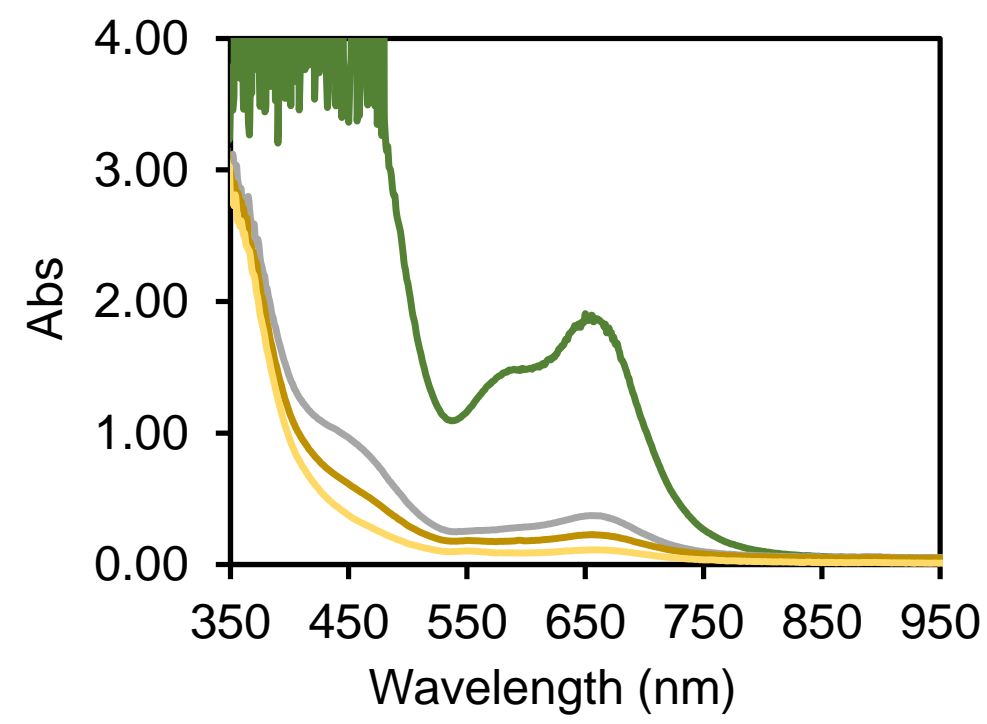

Figure S34. UV-Vis spectra of the reaction mixture of $1-\mathrm{BAr}_{4}{ }_{4}$ and 2.0 eq. $\mathrm{PhCH}_{2} \mathrm{CH}_{2} \mathrm{SNO}$ followed by addition of propionitrile (green trace at $-80{ }^{\circ} \mathrm{C}$, gray trace at $-70{ }^{\circ} \mathrm{C}$, khaki trace at $-60{ }^{\circ} \mathrm{C}$, and yellow trace at $\left.-50{ }^{\circ} \mathrm{C}\right)$.

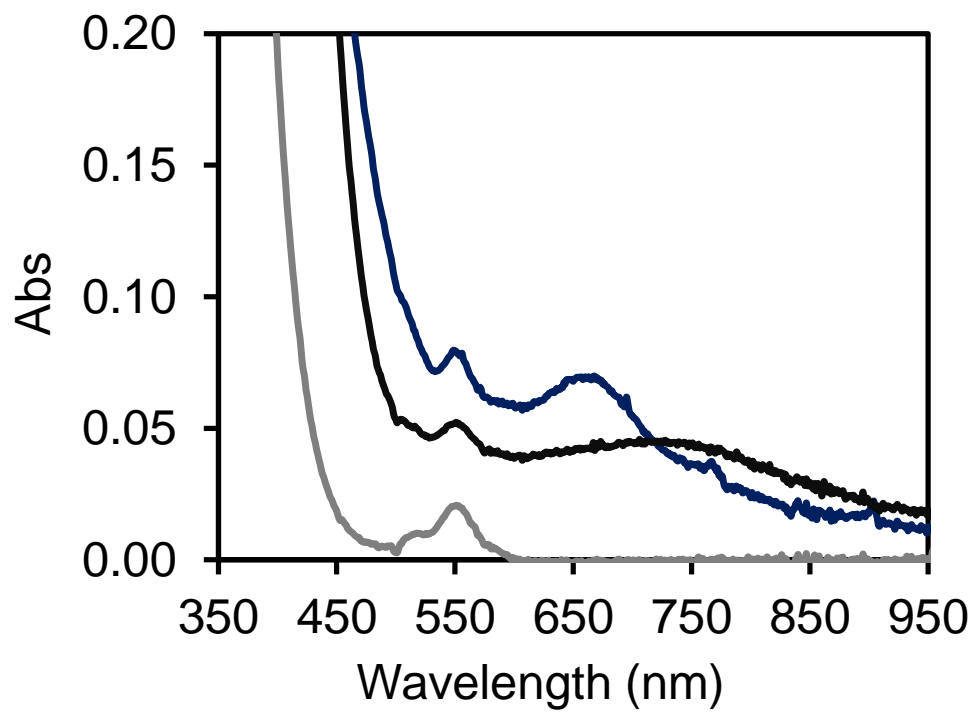

Figure S35. UV-Vis spectra of the reaction mixture of 1-BAr ${ }_{4}{ }_{4}$ and 2.0 eq. $\mathrm{PhCH}_{2} \mathrm{CH}_{2} \mathrm{SNO}$ followed by addition of propionitrile (blue trace at $-40{ }^{\circ} \mathrm{C}$, black trace at $20{ }^{\circ} \mathrm{C}$ ). The gray trace is $1.5 \mathrm{mM}$ free $\mathrm{PhCH}_{2} \mathrm{CH}_{2} \mathrm{SNO}$ in the same mixed solvent at $20{ }^{\circ} \mathrm{C}$. 
Quantification of $\mathrm{PhCH}_{2} \mathrm{CH}_{2} \mathrm{SNO}$ from the reaction of 2-BAr ${ }_{4}$ with two equivalents of $\mathrm{PhCH}_{2} \mathrm{CH}_{2} \mathrm{SH}$

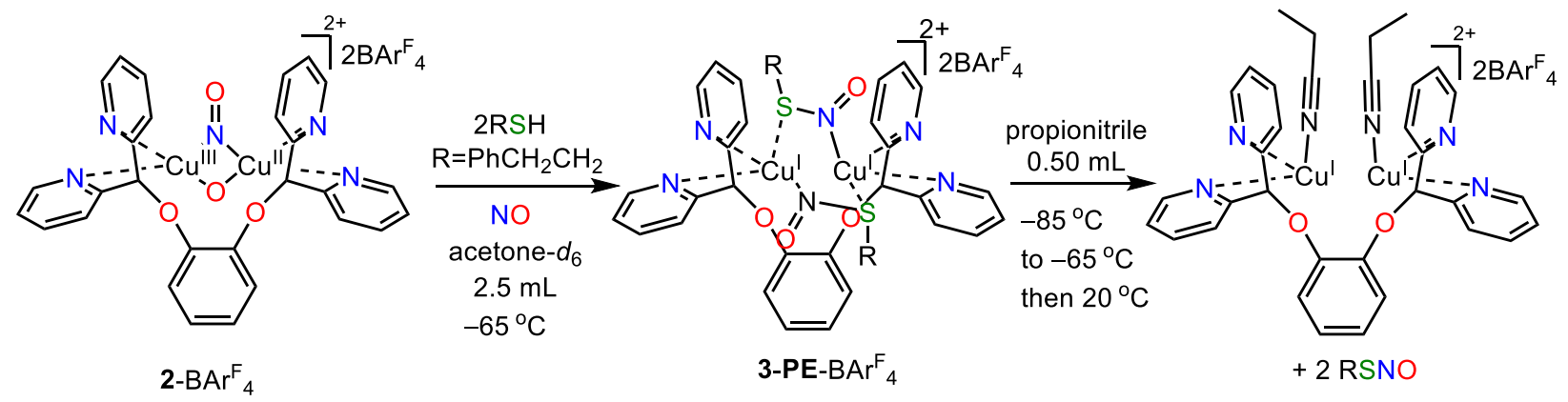

In the glovebox, an acetone- $d_{6}$ solution of $1-\mathrm{BAr}_{4}{ }_{4}(5.4 \mathrm{mg}, 2.3 \mu \mathrm{mol}, 2.3 \mathrm{~mL})$ and internal standard 1,3,5trimethoxybenzene $(1.2 \mathrm{mg}, 7.1 \mu \mathrm{mol})$ were placed in a quartz cuvette equipped with a rubber septum. The cuvette was sealed and transferred to the UV-Vis spectrometer precooled at $-45^{\circ} \mathrm{C}$. After the temperature stabilized, NO $(2.0 \mathrm{~mL}, 83 \mu \mathrm{mol}, 37$ eq.) was injected into the solution and the reaction progress was monitored by taking a UV-Vis spectrum every 60 seconds until the dicopper $\mu$-oxo, $\mu$-nitrosyl 2 -BAr ${ }_{4}{ }_{4}$ band at $525 \mathrm{~nm}$ reached an absorbance of $c a .2 .44$ and stabilized. The cuvette was cooled to $-80{ }^{\circ} \mathrm{C}$ and stabilized before $\mathrm{PhCH}_{2} \mathrm{CH}_{2} \mathrm{SH}\left(0.20 \mathrm{~mL}, 22.5 \mathrm{mM}\right.$ in acetone- $d_{6}, 4.6 \mu \mathrm{mol}, 2.0$ equiv. $)$ was injected to the solution, and the reaction progress was monitored by taking a UV-vis spectrum every 60 seconds. The UVvis bands of the proposed dicopper(I,I) di-S-nitrosothiol species $\left(\lambda_{\max }=575 \mathrm{~nm}, \varepsilon=2100 \mathrm{M}^{-1} \mathrm{~cm}^{-1}\right.$ and $\lambda_{\max }$ $=675 \mathrm{~nm}, \varepsilon=1300 \mathrm{M}^{-1} \mathrm{~cm}^{-1}$ ) were observed at $-65{ }^{\circ} \mathrm{C}$. After the spectrum stabilized, the solution was cooled to $-85{ }^{\circ} \mathrm{C}$ and propionitrile $(0.50 \mathrm{~mL}, 7.2 \mathrm{mmol}, 3100$ eq. $)$ was injected to the solution and the reaction was monitored by taking $\mathrm{UV}-\mathrm{V}$ is spectrum every 60 seconds. After the spectra stabilized at $-85^{\circ} \mathrm{C}$, the temperature was increased to $-65^{\circ} \mathrm{C}$ and the reaction was monitored by UV-vis until stabilized. These procedures were repeated as the temperature was increased to $-50{ }^{\circ} \mathrm{C}$ and $-40{ }^{\circ} \mathrm{C}$ (Figure S36). Once the spectrum stabilized at $-40{ }^{\circ} \mathrm{C}$, the solution was warmed up to $20^{\circ} \mathrm{C}$ and free S-nitrosothiol $\mathrm{PhCH}_{2} \mathrm{CH}_{2} \mathrm{SNO}$ signals around $550 \mathrm{~nm}$ were observed (Figure S37). The resulting solution was analyzed by ${ }^{1} \mathrm{H}$ NMR, however, because of the large amount of propionitrile, the S-nitrosothiol signals can not be quantified very well (Figure S38). With this result, we decide to use $\mathrm{CD}_{3} \mathrm{CN}$ instead of propionitrile to reduce its interference during ${ }^{1} \mathrm{H}$ NMR quantification. 


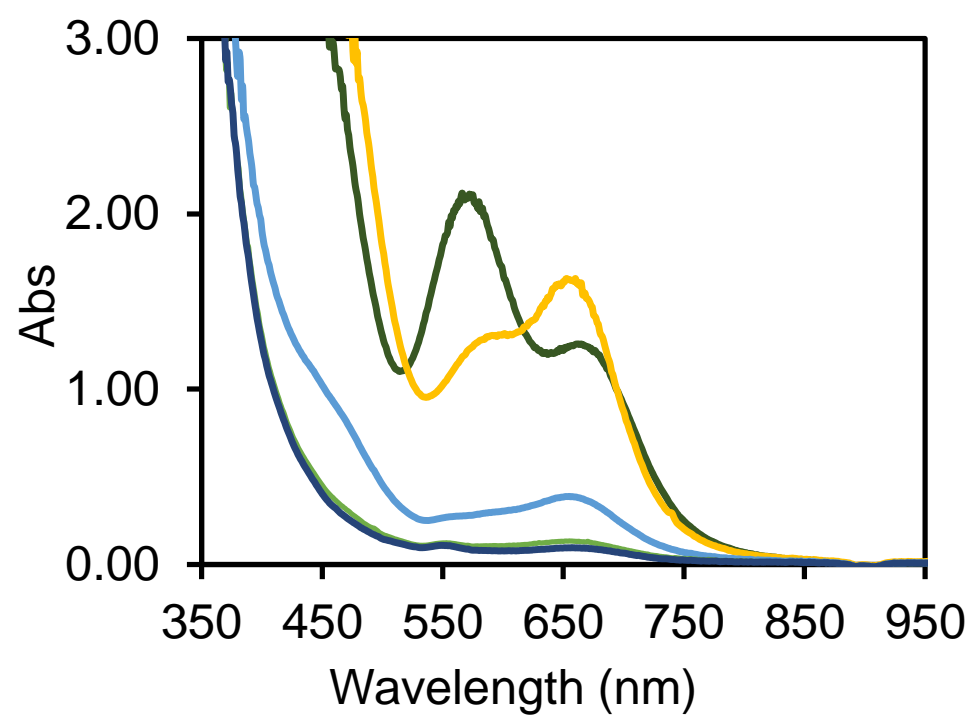

Figure S36. UV-Vis spectra of the reaction mixture of 3-PE-B $\operatorname{Ar}^{\mathrm{F}}{ }_{4}$ (dark green trace at $-65^{\circ} \mathrm{C}$ ) and excess propionitrile (yellow trace at $-85^{\circ} \mathrm{C}$, light blue trace at $-65^{\circ} \mathrm{C}$, light green trace at $-50{ }^{\circ} \mathrm{C}$ and blue trace at $\left.-40{ }^{\circ} \mathrm{C}\right)$.

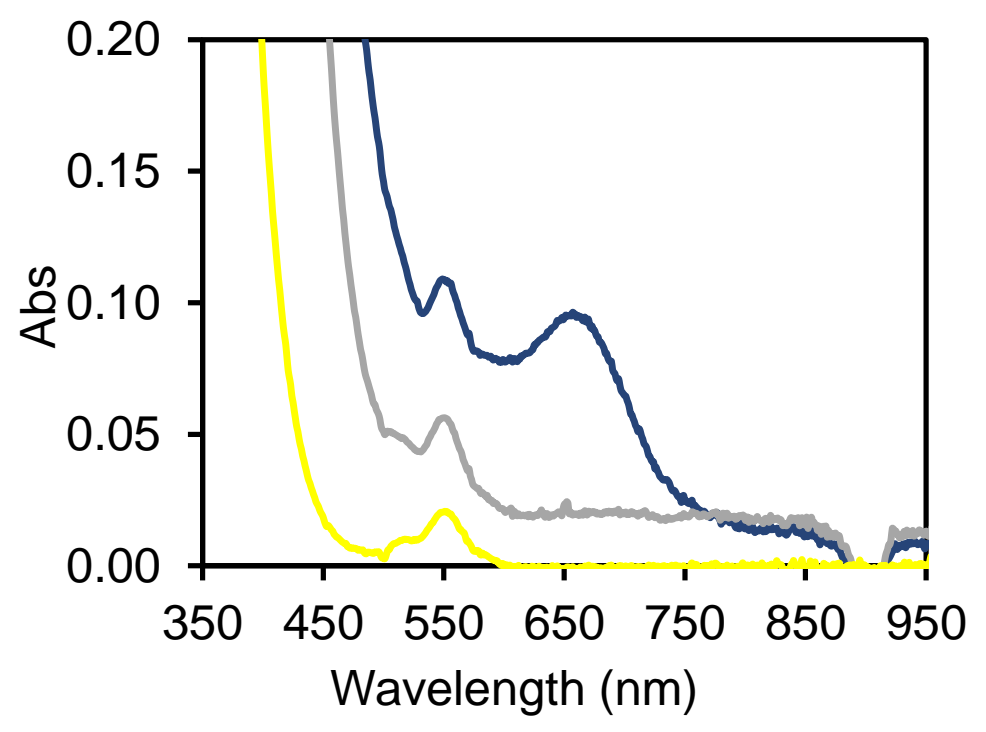

Figure S37. UV-Vis spectra of the reaction mixture of 3-PE-BAr ${ }_{4}$ and excess propionitrile (blue trace at $-40{ }^{\circ} \mathrm{C}$, gray trace at $20^{\circ} \mathrm{C}$ ). The $1.5 \mathrm{mM}$ free $\mathrm{PhCH}_{2} \mathrm{CH}_{2} \mathrm{SNO}$ spectra in the same mixed solvent is shown as yellow trace for comparison. 


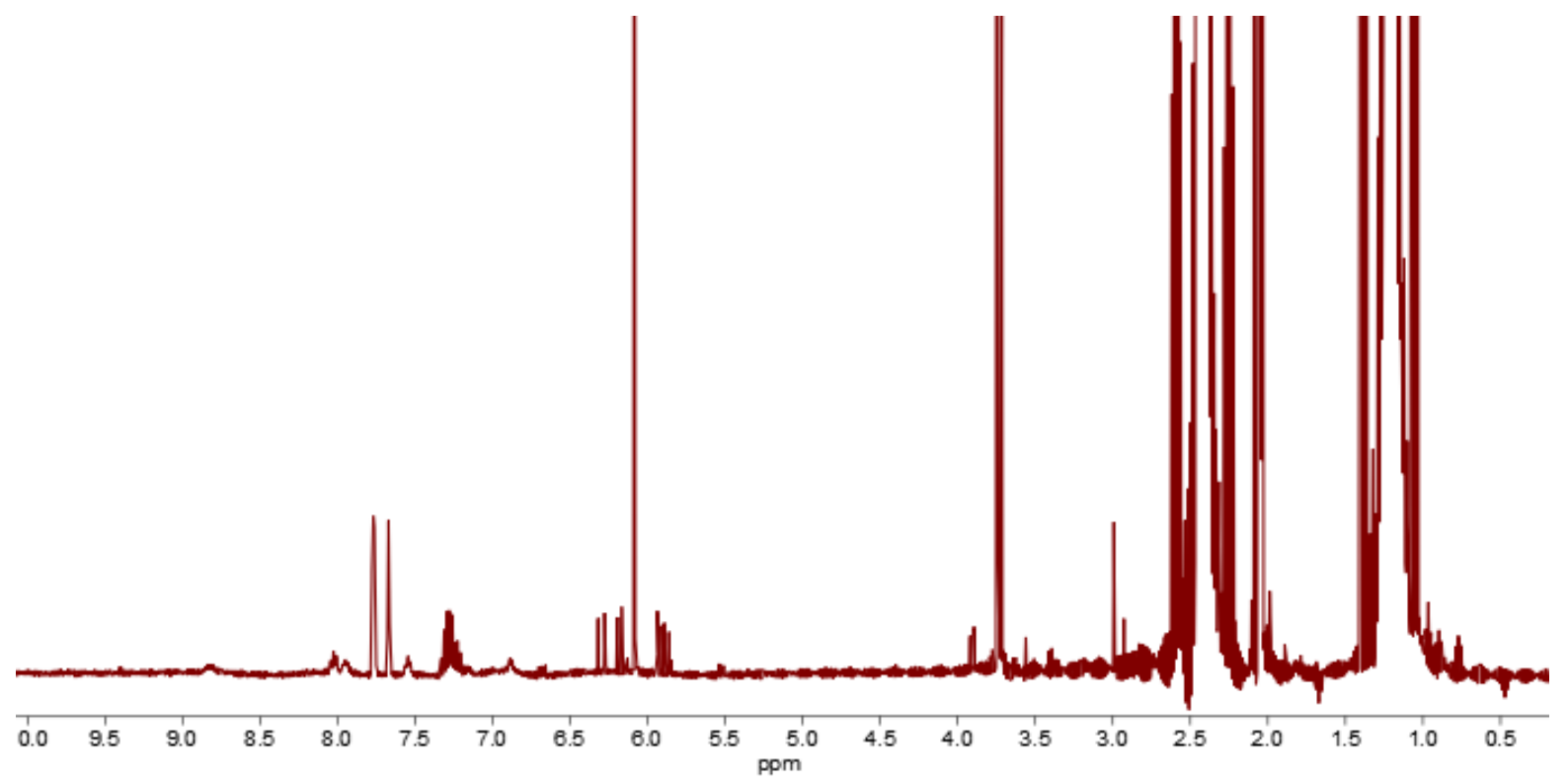

Figure S38. ${ }^{1} \mathrm{H}$ NMR (400 MHz, acetone- $d_{6}$ ) of the reaction mixture of 3-PE-BAr ${ }^{F_{4}}$ with excess amount of propionitrile.

Quantification of $\mathrm{PhCH}_{2} \mathrm{CH}_{2} \mathrm{SNO}$ from the reaction of 2-BAr ${ }_{4}$ with two equivalents of $\mathrm{PhCH}_{2} \mathrm{CH}_{2} \mathrm{SH}$ with $\mathrm{CD}_{3} \mathrm{CN}$

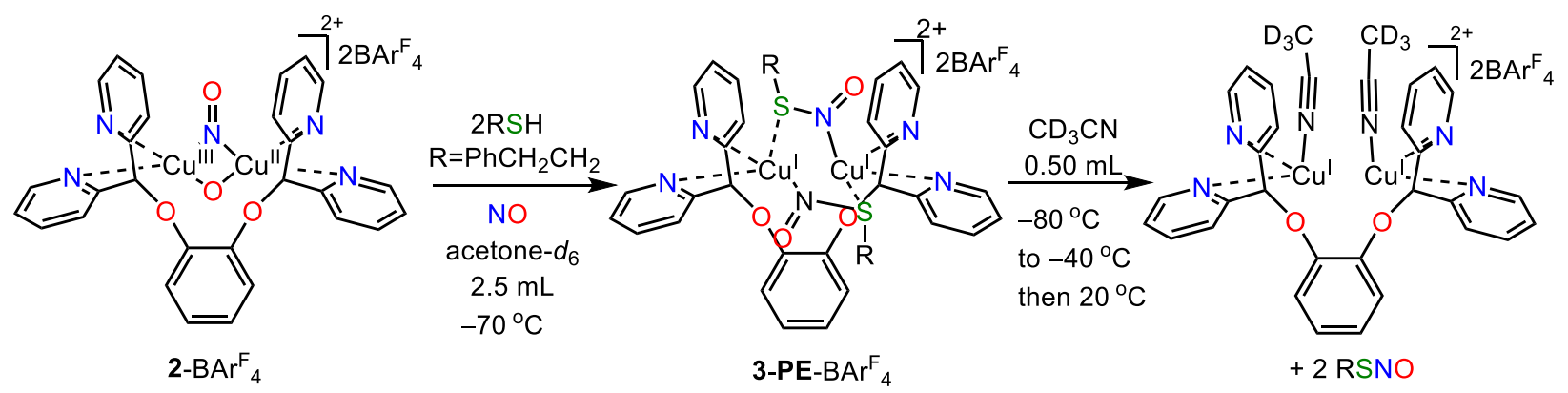

In the glovebox, an acetone- $d_{6}$ solution of $1-\mathrm{BAr}^{\mathrm{F}} 4(5.4 \mathrm{mg}, 2.27 \mu \mathrm{mol}, 2.3 \mathrm{~mL})$ was placed in a Schlenk quartz cuvette. The cuvette was sealed and transferred to the UV-Vis spectrometer precooled at $-50{ }^{\circ} \mathrm{C}$. After the temperature stabilized, NO $(5.0 \mathrm{~mL}, 208 \mu \mathrm{mol}, 92$ eq.) was injected into the solution and the reaction progress was monitored by taking a UV-Vis spectrum every 60 seconds until the dicopper $\mu$-oxo, $\mu$-nitrosyl 2-BAr ${ }_{4}$ feature band at $525 \mathrm{~nm}$ reached an absorbance of $c a .2 .18$ and stabilized. The cuvette was cooled to $-80{ }^{\circ} \mathrm{C}$. $\mathrm{PhCH}_{2} \mathrm{CH}_{2} \mathrm{SH}\left(0.21 \mathrm{~mL}, 22.5 \mathrm{mM}\right.$ in acetone- $d_{6}, 4.7 \mu \mathrm{mol}, 2.1$ equiv. $)$ was injected to the solution, and the reaction progress was monitored by taking a UV-vis spectrum every 60 seconds. After ca. $20 \mathrm{~min}$, the Schlenk cuvette was sealed and transferred to a $-70{ }^{\circ} \mathrm{C}$ cold bath and stored at this temperature for $24 \mathrm{~h}$. The color of the solution changed from dark red to dark green. The Schlenk cuvette was then transferred back to the UV-Vis spectrometer precooled at $-80{ }^{\circ} \mathrm{C}$. After the temperature was stabilized, an acetonitrile- $d_{3}(0.50 \mathrm{~mL}, 9.6 \mathrm{mmol}, 4300$ eq. $)$ solution of internal standard 1,3,5trimethoxybenzene $(1.9 \mathrm{mg}, 11.1 \mu \mathrm{mol})$ was injected to the solution and the reaction was monitored by taking a UV-Vis spectrum every minute. After the spectrum stabilized at $-80{ }^{\circ} \mathrm{C}$, the temperature was increased to $-70{ }^{\circ} \mathrm{C}$ and the reaction was monitored until the spectrum stabilized. These procedures were 
repeated as the temperature was increased to $-60{ }^{\circ} \mathrm{C},-50{ }^{\circ} \mathrm{C},-40{ }^{\circ} \mathrm{C},-20{ }^{\circ} \mathrm{C},-10{ }^{\circ} \mathrm{C}, 0{ }^{\circ} \mathrm{C}$ and finally $20^{\circ} \mathrm{C}$ (Figure S39-40). Free S-nitrosothiol $\mathrm{PhCH}_{2} \mathrm{CH}_{2} \mathrm{SNO}$ signals around $550 \mathrm{~nm}$ were observed (Figure S37). The resulting solution was analyzed by quantitative ${ }^{1} \mathrm{H}$ NMR (relaxation time 20s). The existence of free $\mathrm{PhCH}_{2} \mathrm{CH}_{2} \mathrm{SNO}$ can be confirmed by comparison with the ${ }^{1} \mathrm{H}$ NMR spectrum of the pure $\mathrm{PhCH}_{2} \mathrm{CH}_{2} \mathrm{SNO}$ containing internal standard 1,3,5-trimethoxybenzene in acetone- $d_{6}$ (Figure S41). The amount of $\mathrm{PhCH}_{2} \mathrm{CH}_{2} \mathrm{SNO}$ formed in the reaction of dicopper $\mu$-oxo, $\mu$-nitrosyl 2-BAr${ }_{4}$ with two equivalents of phenylethanethiol is $94 \%$ based on the integration of ${ }^{1} \mathrm{H}$ NMR (Figure S42), considering two equivalents of $\mathrm{PhCH}_{2} \mathrm{CH}_{2} \mathrm{SNO}$ would be formed relative to $2-\mathrm{BAr}_{4}$. This $S$-nitrosothiol quantification experiment supports our hypothesis that the new green species $\left(\lambda_{\max }=575 \mathrm{~nm}, \varepsilon=2400 \mathrm{M}^{-1} \mathrm{~cm}^{-1}\right.$ and $\lambda_{\max }$ $\left.=675 \mathrm{~nm}, \varepsilon=1450 \mathrm{M}^{-1} \mathrm{~cm}^{-1}\right)$ is dicopper(I,I) di-S-nitrosothiol complex.

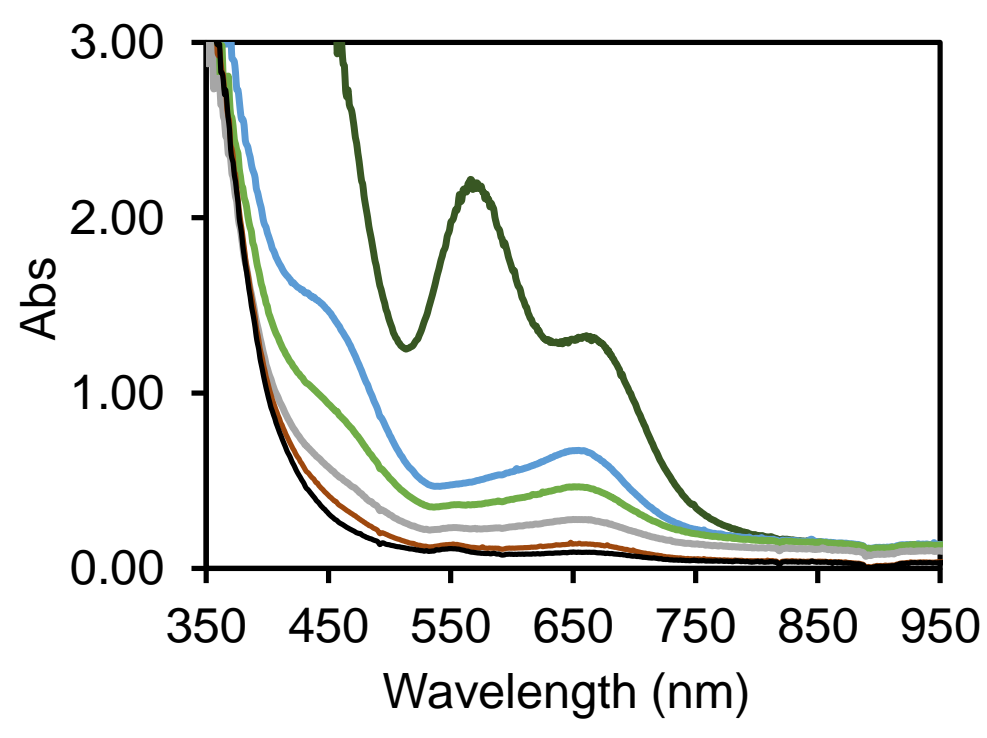

Figure S39. UV-Vis spectra of the reaction mixture of 3-PE-B $\mathrm{Fr}_{4}{ }_{4}$ (dark green trace at $-80{ }^{\circ} \mathrm{C}$ ) and excess acetonitrile- $d_{3}$ (blue trace at $-80{ }^{\circ} \mathrm{C}$, light green trace at $-70{ }^{\circ} \mathrm{C}$, gray trace at $-60{ }^{\circ} \mathrm{C}$, brown trace at $-50{ }^{\circ} \mathrm{C}$ and black trace at $-40{ }^{\circ} \mathrm{C}$ ). 


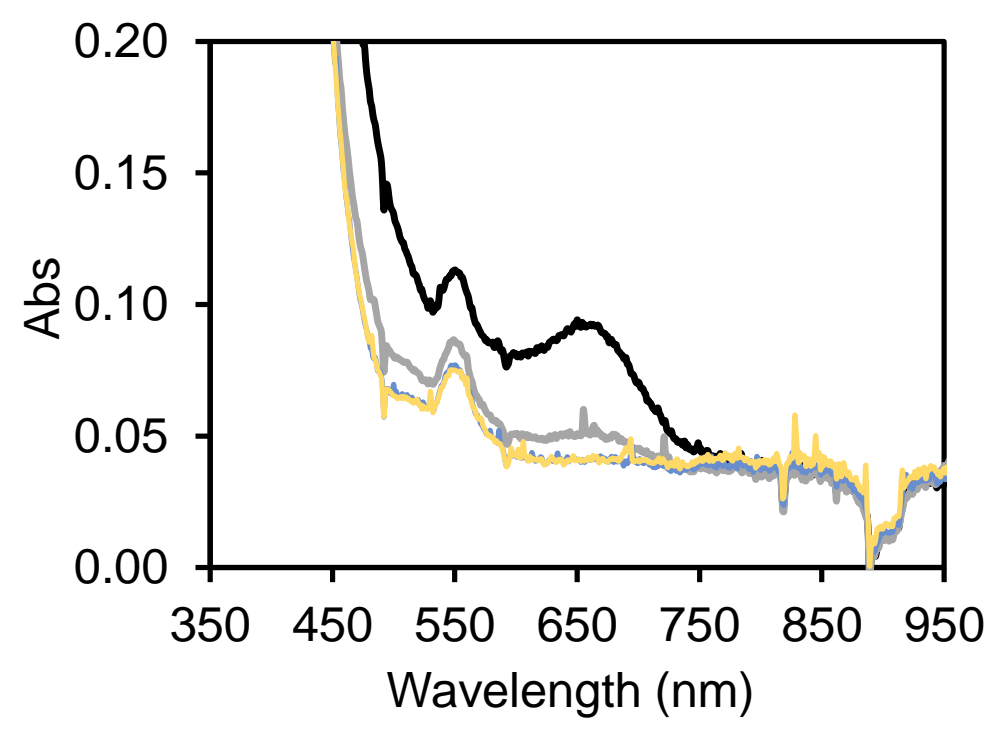

Figure S40. UV-Vis spectra of the reaction mixture of 3-PE-B Ar ${ }_{4}{ }_{4}$ and excess acetonitrile- $d_{3}$ (black trace at $-40{ }^{\circ} \mathrm{C}$, gray trace at $-20^{\circ} \mathrm{C}$, blue trace at $0{ }^{\circ} \mathrm{C}$ and yellow trace at $20^{\circ} \mathrm{C}$ ).
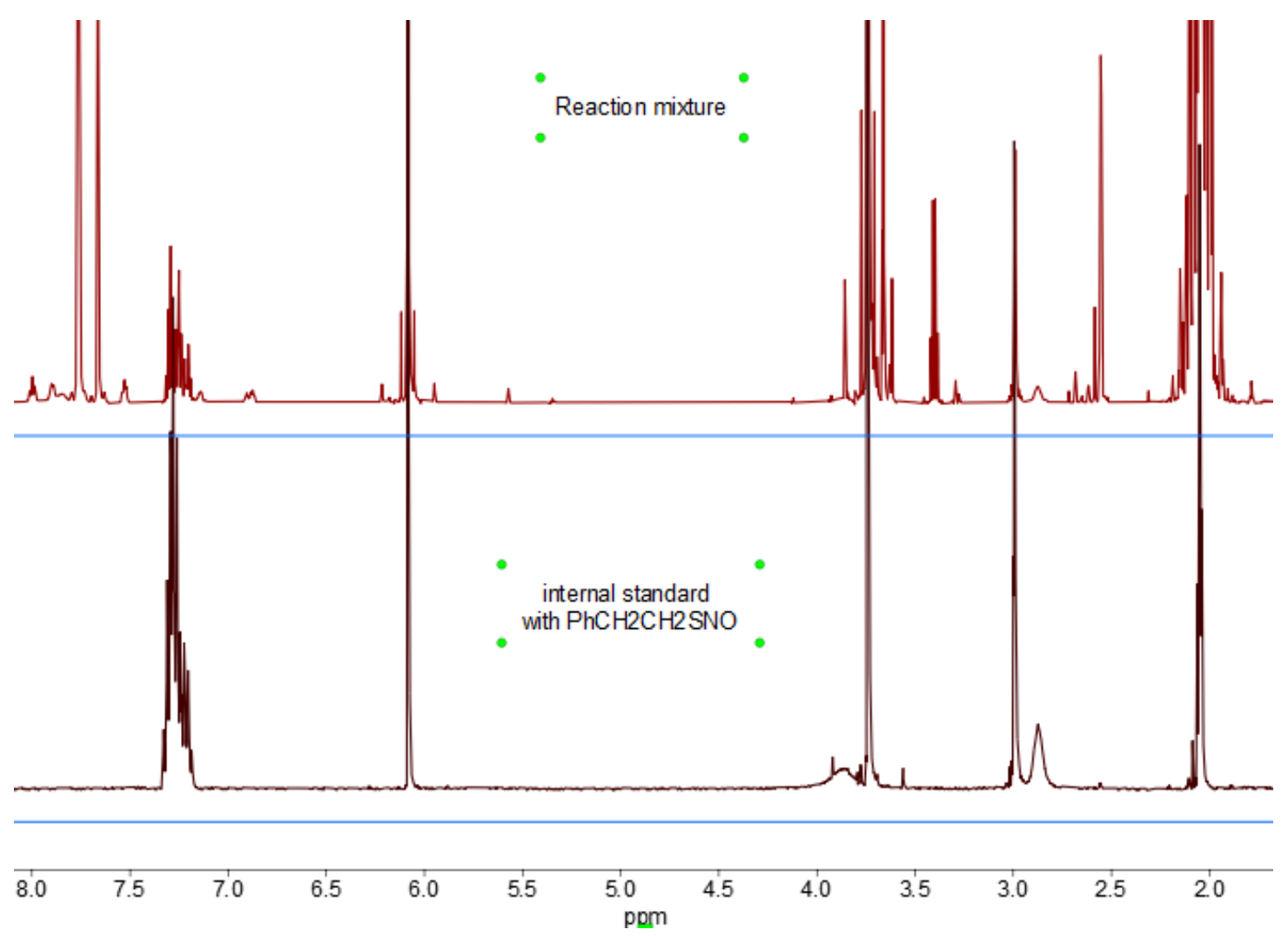

Figure S41. ${ }^{1} \mathrm{H}$ NMR (600 MHz, acetone- $\left.d_{6}\right)$ of $1-\mathrm{BAr}^{\mathrm{F}}{ }_{4}$ and $\mathrm{NO}$ with two equivalents of 2-phenyl ethanethiol followed by addition of excess acetonitrile- $d_{3}$ in acetone- $d_{6}$ (top) and free $\mathrm{PhCH}_{2} \mathrm{CH}_{2} \mathrm{SNO}$ and internal standard 1,3,5-trimethoxybenzene in acetone- $d_{6}$ (bottom). 


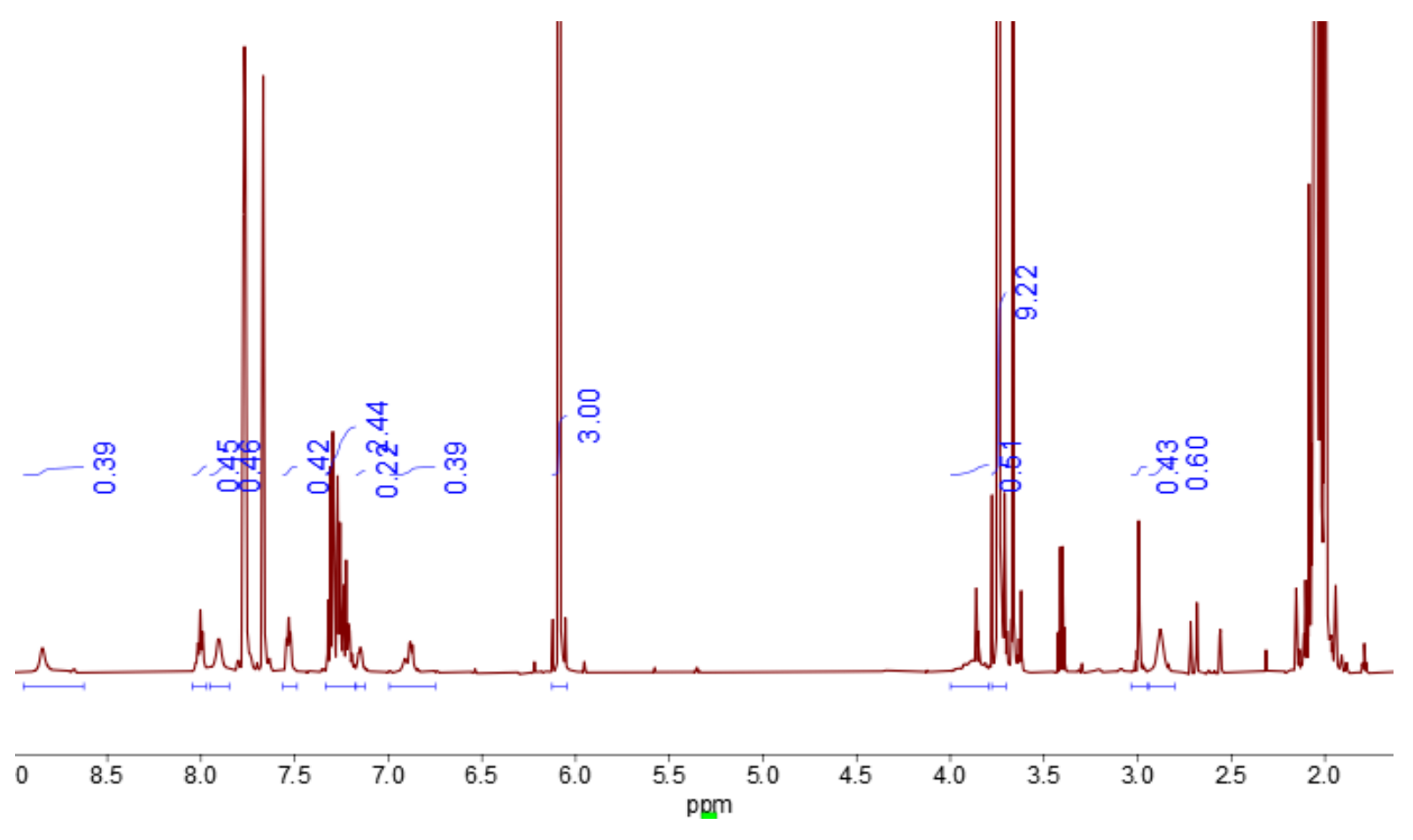

Figure S42. ${ }^{1} \mathrm{H}$ NMR (600 MHz, acetone- $\left.d_{6}\right)$ of 3-PE-B Ar ${ }_{4}{ }_{4}$ and excess acetonitrile- $d_{3}$ in acetone- $d_{6}$.

Note: The amount of internal standard 1,3,5-trimethoxybenzene used in this experiment is $1.9 \mathrm{mg}$ (11.1 $\mu \mathrm{mol})$. The amount of dicopper (I,I) precursor $1-\mathrm{BAr}_{4}$ used in this experiment is $5.4 \mathrm{mg}(2.27 \mu \mathrm{mol})$. The $\mathrm{PhCH}_{2} \mathrm{CH}_{2} \mathrm{SNO}$ has $\mathrm{CH}_{2}$ signals at $2.995 \mathrm{ppm}, 2.878 \mathrm{ppm}, 3.891 \mathrm{ppm}$ because of the existence of two isomers and $\mathrm{Ph}$ signals are between $7.321 \mathrm{ppm}$ and $7.195 \mathrm{ppm}$. The total $\mathrm{CH}_{2}$ signal integral is $0.51+0.43+0.60=1.54$, therefore the $\mathrm{PhCH}_{2} \mathrm{CH}_{2} \mathrm{SNO}$ generated is $1.54 / 4 \times 11.1=4.27 \mu$ mol. The maximum $\mathrm{PhCH}_{2} \mathrm{CH}_{2} \mathrm{SNO}$ that is formed is two equivalents relative to $2-\mathrm{BAr}_{4}$, which is $2 \times 2.27=4.54 \mu \mathrm{mol}$. As a result, the yield of $\mathrm{PhCH}_{2} \mathrm{CH}_{2} \mathrm{SNO}$ formation is 4.27/4.54 =94\%. The recovered dicopper(I,I) precursor 1$\mathrm{BAr}_{4}$ has characterized signals in the aromatic area. The recovered amount of $1-\mathrm{BAr}_{4}$ is ca. $0.42 / 4 \times 11.1=1.17 \mu \mathrm{mol}$, therefore the recovered yield is $c a .1 .17 / 2.27=51 \%$.

\section{Reaction of 1-BAr ${ }_{4}{ }^{\mathrm{w}}$ with $2.0 \mathrm{eq}$. $\mathrm{N}$-acetyl- $L$-cysteine methyl ester $S$-nitrosothiol in acetone}
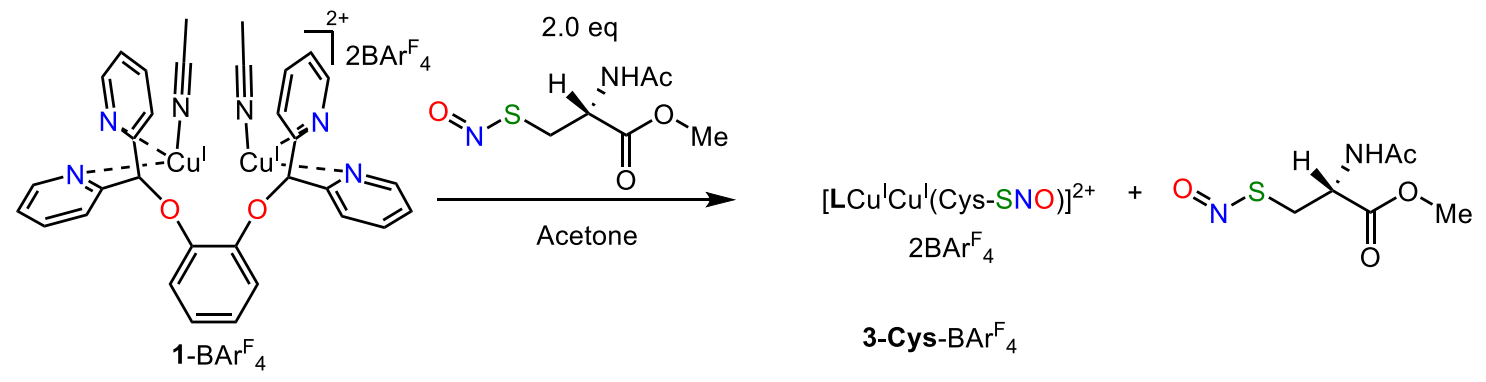

In the glovebox, an acetone solution of $1-\mathrm{BAr}_{4}{ }_{4}(5.4 \mathrm{mg}, 2.3 \mu \mathrm{mol}, 2.80 \mathrm{~mL})$ was placed in a quartz cuvette equipped with a rubber septum. The cuvette was sealed and transferred to the UV-Vis spectrometer precooled at $-80^{\circ} \mathrm{C}$. After the temperature stabilized, $\mathrm{N}$-acetyl-L-cysteine methyl ester S-nitrosothiol $(0.10$ $\mathrm{mL}, 22.5 \mathrm{mM}$ in acetone, $2.3 \mu \mathrm{mol}, 1.0$ equiv.) was injected to the solution, and the reaction progress was 
monitored by taking a UV-vis spectrum every 60 seconds. A new green species $\left(\lambda_{\max }=570 \mathrm{~nm}, \varepsilon=2500\right.$ $\mathrm{M}^{-1} \mathrm{~cm}^{-1}$ and $\lambda_{\max }=670 \mathrm{~nm}, \varepsilon=2200 \mathrm{M}^{-1} \mathrm{~cm}^{-1}$ ) is generated (Figure S43). A second equivalent of N-acetylL-cysteine methyl ester $\mathrm{S}$-nitrosothiol $(0.10 \mathrm{~mL}, 22.5 \mathrm{mM}$ in acetone, $2.3 \mu \mathrm{mol}, 1.0$ equiv. $)$ was injected to the above solution, and the reaction progress was monitored for another $15 \mathrm{~min}$. The stabilized UV-Vis spectra after the addition of one or two equivalents of $\mathrm{N}$-acetyl-L-cysteine methyl ester S-nitrosothiol are shown in Figure S44. The new green species decayed quickly when the cuvette was warmed up to $-60{ }^{\circ} \mathrm{C}$ in acetone. The titration experiment suggests that only one equivalent of $\mathrm{N}$-acetyl- $L$-cysteine methyl ester $\mathrm{S}$-nitrosothiol binds to dicooper(I,I) precursor $1-\mathrm{BAr}^{\mathrm{F}}$. It is possible that the $\mathrm{SNO}$ moiety binds to one copper(I) center while the ester or amide functional group coordinates to the other copper(I) center in 1$\mathrm{BAr}_{4}^{\mathrm{F}}$.

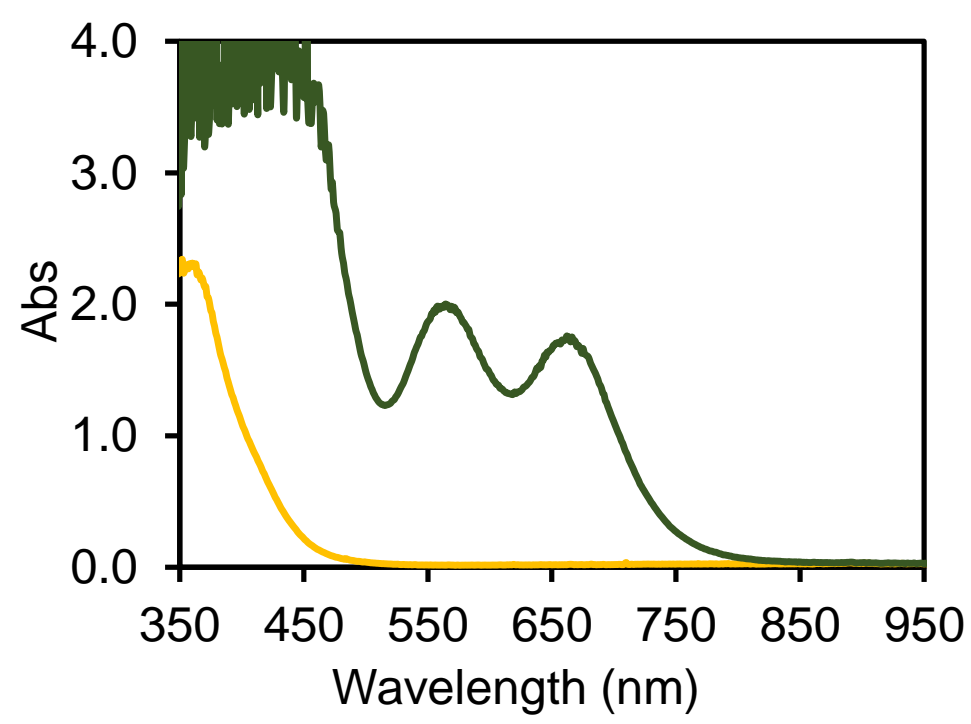

Figure S43. UV-Vis spectra of the reaction mixture of $1-\mathrm{BAr}_{4}{ }_{4}$ (yellow trace) and one equivalent of Snitroso $\mathrm{N}$-acetyl-L-cysteine methyl ester (green trace at $-80{ }^{\circ} \mathrm{C}$ in acetone). 


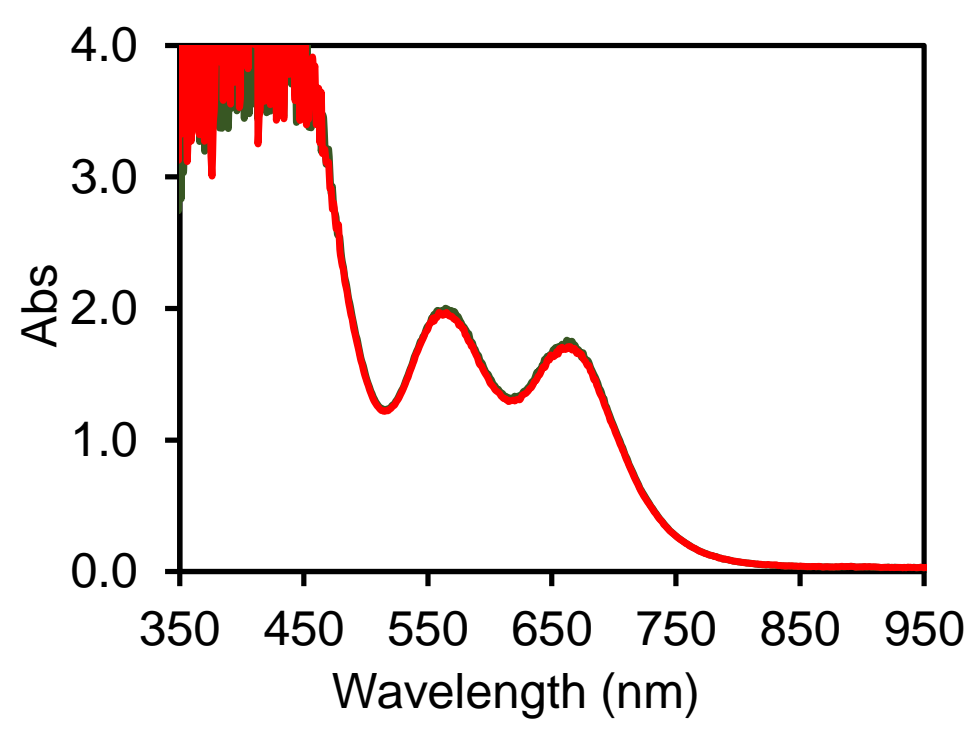

Figure S44. UV-Vis spectra of the reaction mixture of $1-\mathrm{BAr}^{\mathrm{F}}{ }_{4}$ with one equivalent of S-nitroso N-acetylL-cysteine methyl ester (green trace at $-80^{\circ} \mathrm{C}$ in acetone) followed by a second equivalent of S-nitroso $\mathrm{N}$ acetyl-L-cysteine methyl ester (red trace at $-80^{\circ} \mathrm{C}$ in acetone).

\section{Reaction of $2-\mathrm{BAr}^{\mathrm{F}}{ }_{4}$ with $2.0 \mathrm{eq}$. $\mathrm{N}$-acetyl- $L$-cysteine methyl ester in acetone}

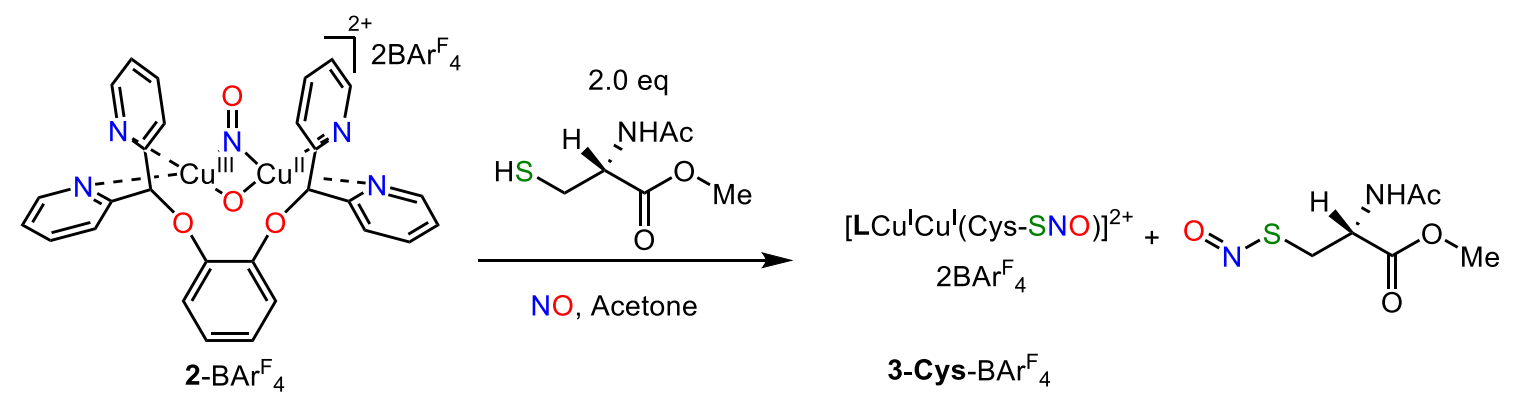

In the glovebox, an acetone solution of 1-B $\mathrm{Br}_{4}{ }_{4}(5.4 \mathrm{mg}, 2.3 \mu \mathrm{mol}, 2.8 \mathrm{~mL})$ was placed in a Schlenk quartz cuvette. The cuvette was sealed and transferred to the UV-Vis spectrometer precooled at $-50{ }^{\circ} \mathrm{C}$. After the temperature stabilized, NO $(2.0 \mathrm{~mL}, 83 \mu \mathrm{mol}, 37 \mathrm{eq}$. $)$ was injected into the solution and the reaction progress was monitored by taking a UV-Vis spectrum every 60 seconds until the dicopper $\mu$-oxo, $\mu$-nitrosyl $2-\mathrm{BAr}_{4}{ }_{4}$ band at $525 \mathrm{~nm}$ reached absorbance of $c a .2 .10$ and stabilized. The cuvette was cooled to $-80{ }^{\circ} \mathrm{C}$ before $\mathrm{N}$-acetyl-L-cysteine methyl ester $(0.20 \mathrm{~mL}, 22.5 \mathrm{mM}$ in acetone, $4.5 \mu \mathrm{mol}, 2.0$ equiv.) was injected to the solution. The reaction progress was monitored by taking a UV-vis spectrum every 60 seconds. After ca. $20 \mathrm{~min}$, the Schlenk cuvette was sealed and transferred to a $-70{ }^{\circ} \mathrm{C}$ cold bath and stored at this temperature for $24 \mathrm{~h}$. The color of the solution changed from dark red to dark green. The Schlenk cuvette was transferred back to UV-Vis spectrometer precooled at $-80{ }^{\circ} \mathrm{C}$. A new green species $\left(\lambda_{\max }=570 \mathrm{~nm}, \varepsilon\right.$ $=2500 \mathrm{M}^{-1} \mathrm{~cm}^{-1}$ and $\lambda_{\max }=670 \mathrm{~nm}, \varepsilon=2200 \mathrm{M}^{-1} \mathrm{~cm}^{-1}$ ) was generated (Figure S45). The comparison of this spectrum with that from the reaction of $1-\mathrm{BAr}_{4}{ }_{4}$ and one equivalent of S-nitroso N-acetyl-L-cysteine methyl ester is shown in Figure S46, which strongly supports that these two methods generate the same product. To further confirm that two equivalents of S-nitroso $\mathrm{N}$-acetyl-L-cysteine methyl ester were formed 
under these conditions, we decided to use $\mathrm{CD}_{3} \mathrm{CN}$ to displace the $S$-nitroso $\mathrm{N}$-acetyl- $L$-cysteine methyl ester binding to copper(I) center and quantify the yield by ${ }^{1} \mathrm{H}$ NMR.

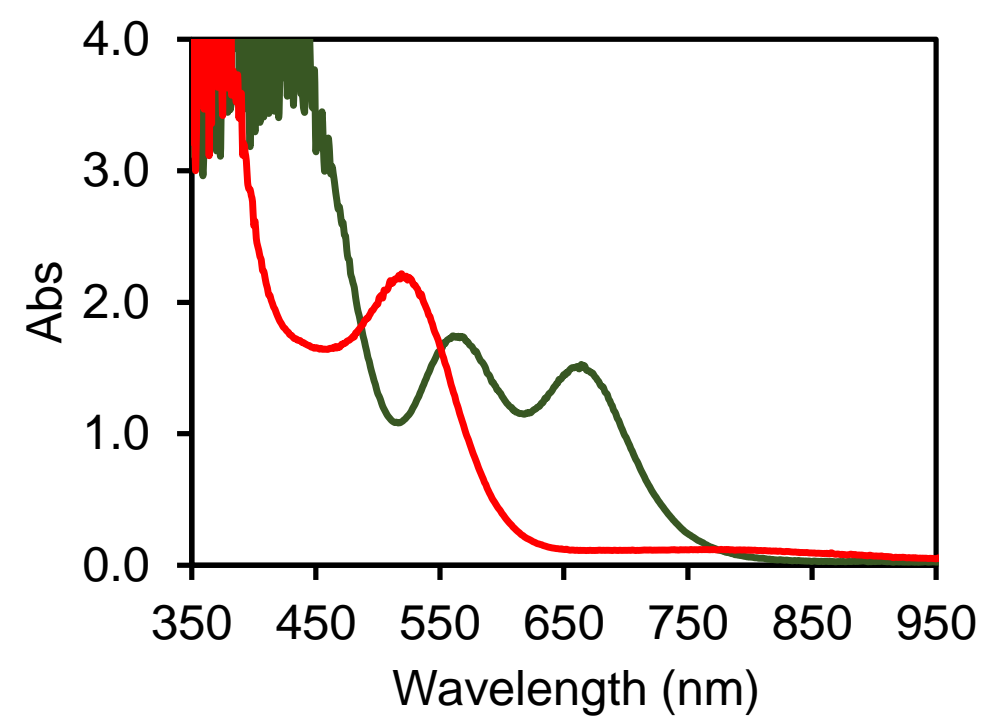

Figure S45. UV-Vis spectra of the reaction mixture of $2-\mathrm{BAr}^{\mathrm{F}}{ }_{4}$ (red trace in acetone at $-80{ }^{\circ} \mathrm{C}$ ) with two equivalents of $\mathrm{N}$-acetyl-L-cysteine methyl ester (green trace at $-80{ }^{\circ} \mathrm{C}$ in acetone after reaction at $-70{ }^{\circ} \mathrm{C}$ for $24 h)$.

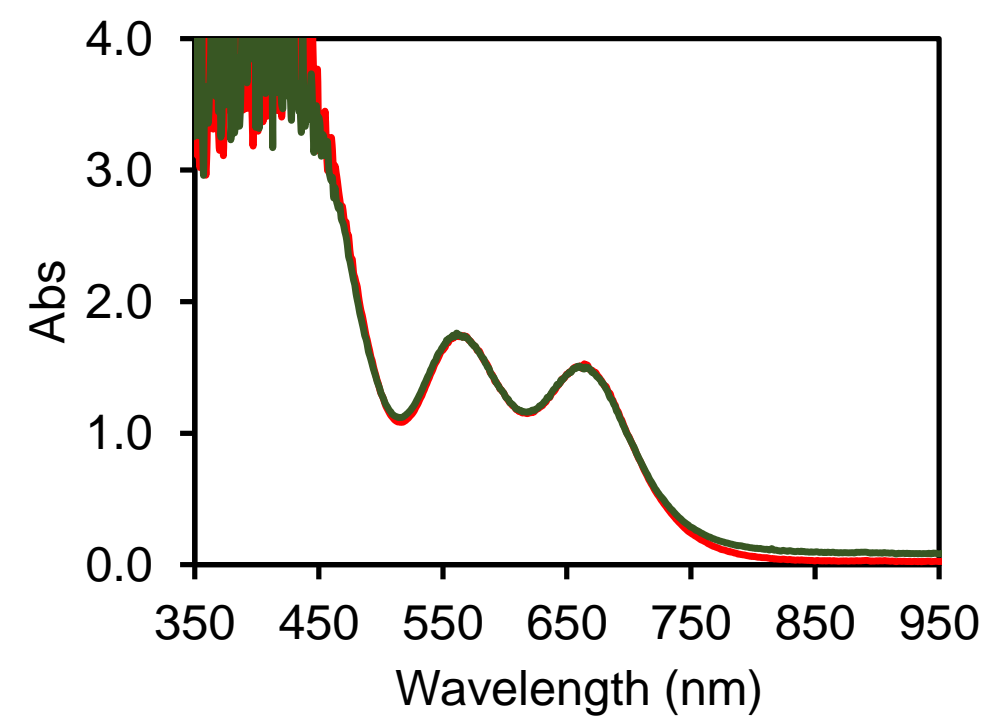

Figure S46. UV-Vis spectra of the reaction mixture of $2-\mathrm{BAr}_{4}{ }_{4}$ with two equivalents of $\mathrm{N}$-acetyl-L-cysteine methyl ester (green trace at $-80{ }^{\circ} \mathrm{C}$ in acetone after reaction at $-70{ }^{\circ} \mathrm{C}$ for $24 \mathrm{~h}$ ) compared with that from reaction mixture of $1-\mathrm{BAr}_{4}{ }_{4}$ with one equivalent of S-nitroso $\mathrm{N}$-acetyl-L-cysteine methyl ester (black trace at $-80{ }^{\circ} \mathrm{C}$ in acetone). 


\section{Quantification of $S$-nitroso $\mathrm{N}$-acetyl- $L$-cysteine methyl ester from the reaction of 2 -BAr ${ }_{4}$ with two}

equivalents of $\mathrm{N}$-acetyl- $L$-cysteine methyl ester
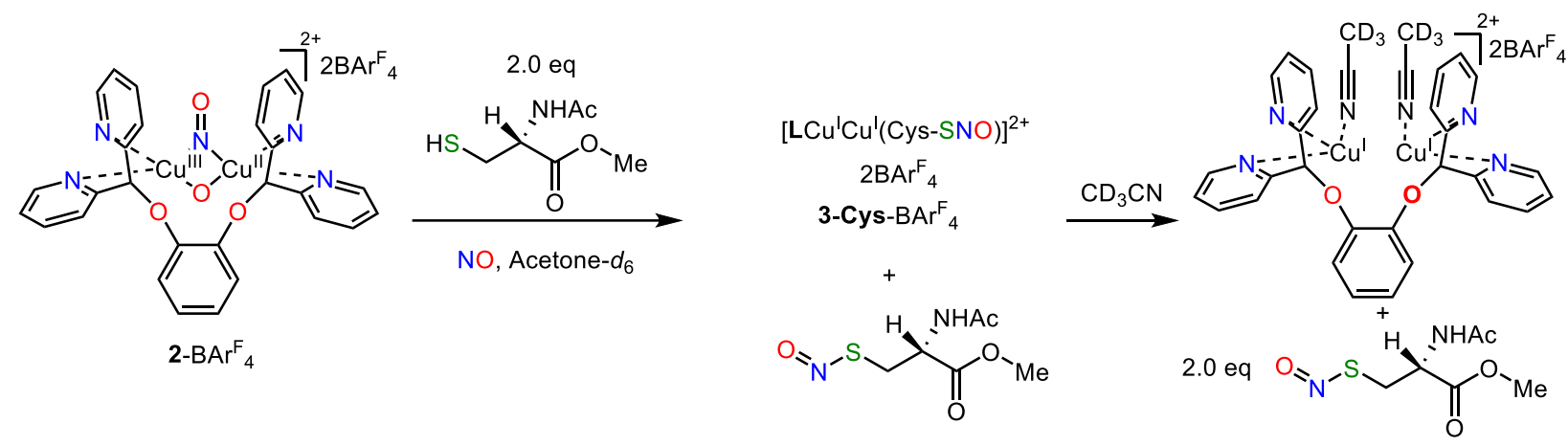

In the glovebox, an acetone- $d_{6}$ solution of $1-\mathrm{BAr}_{4} \mathrm{~F}_{4}(5.4 \mathrm{mg}, 2.27 \mu \mathrm{mol}, 2.8 \mathrm{~mL})$ was placed in a Schlenk quartz cuvette. The cuvette was sealed and transferred to the UV-Vis spectrometer precooled at $-50{ }^{\circ} \mathrm{C}$. After the temperature stabilized, NO $(3.0 \mathrm{~mL}, 125 \mu \mathrm{mol}, 56 \mathrm{eq}$.) was injected into the solution and the reaction progress was monitored by taking a UV-Vis spectrum every 60 seconds until the dicopper $\mu$-oxo, $\mu$-nitrosyl 2-B Ar $\mathrm{F}_{4}$ band at $525 \mathrm{~nm}$ stabilized. The cuvette was cooled to $-80{ }^{\circ} \mathrm{C}$ before $\mathrm{N}$-acetyl- $L$-cysteine methyl ester $\left(0.10 \mathrm{~mL}, 45 \mathrm{mM}\right.$ in acetone- $d_{6}, 4.5 \mu \mathrm{mol}, 2.0$ equiv.) was injected to the solution, and the reaction progress was monitored by taking a UV-vis spectrum every 60 seconds. After ca. 20 min, the Schlenk cuvette was sealed and transferred to a $-70{ }^{\circ} \mathrm{C}$ cold bath and the reaction continued at this temperature for $20 \mathrm{~h}$. The color of the solution changed from red to dark green. The Schlenk cuvette was then transferred back to UV-Vis spectrometer precooled at $-80^{\circ} \mathrm{C}$. The same green species $\left(\lambda_{\max }=570 \mathrm{~nm}\right.$, $\varepsilon=2500 \mathrm{M}^{-1} \mathrm{~cm}^{-1}$ and $\lambda_{\max }=670 \mathrm{~nm}, \varepsilon=2200 \mathrm{M}^{-1} \mathrm{~cm}^{-1}$ ) was generated. The Schlenk cuvette was further cooled to $-90{ }^{\circ} \mathrm{C}$ before an acetonitrile- $d_{3}(0.30 \mathrm{~mL}, 5.7 \mathrm{mmol}, 2500$ eq. $)$ solution of internal standard 1,3,5trimethoxybenzene $(2.2 \mathrm{mg}, 12.9 \mu \mathrm{mol})$ was injected to the solution. After the spectrum stabilized at $-90{ }^{\circ} \mathrm{C}$, the temperature was increased to $-80{ }^{\circ} \mathrm{C}$ and the reaction was monitored with UV-vis until stabilized. These procedures were repeated as the temperature was increased to $-70{ }^{\circ} \mathrm{C},-60{ }^{\circ} \mathrm{C},-50{ }^{\circ} \mathrm{C}$, $-40{ }^{\circ} \mathrm{C},-20^{\circ} \mathrm{C},-10{ }^{\circ} \mathrm{C}$, and finally $0{ }^{\circ} \mathrm{C}$ (Figure S47-48). Free S-nitroso N-acetyl-L-cysteine methyl ester signals around $550 \mathrm{~nm}$ were observed (Figure S48). The solution was not warmed to room temperature because S-nitroso N-acetyl-L-cysteine methyl ester is unstable at room temperature. The resulting solution was maintained below $0{ }^{\circ} \mathrm{C}$ and quickly analyzed by quantitative ${ }^{1} \mathrm{H}$ NMR (relaxation time $20 \mathrm{~s}$ ). We can confirm the existence of free S-nitroso N-acetyl-L-cysteine methyl ester by comparison to the ${ }^{1} \mathrm{H}$ NMR spectrum of pure S-nitroso N-acetyl-L-cysteine methyl in acetone- $d_{6}$ (Figure S49). The amount of $S$-nitroso $\mathrm{N}$-acetyl-L-cysteine methyl ester formed in the reaction of dicopper $\mu$-oxo, $\mu$-nitrosyl 2 -BAr ${ }_{4}{ }_{4}$ with two equivalents of $\mathrm{N}$-acetyl-L-cysteine methyl ester is $88 \%$ based on quantitative ${ }^{1} \mathrm{H}$ NMR (Figure S50) if we consider two equivalents of S-nitrosothiol would be formed relative to $2-\mathrm{BAr}{ }_{4}$. Based on this NAc-cycteine methyl ester $S$-nitrosothiol quantification experiment (Figure S50) together with the above titration experiments (Figure S43, S44, S46), we conclude that two equivalents of $S$-nitroso N-acetyl-L-cysteine methyl ester were generated in this reaction and one equivalent is bound to dicopper(I,I) complex $1-\mathrm{BAr}_{4}{ }_{4}$ to generate the observed new green species $\left(\lambda_{\max }=570 \mathrm{~nm}, \varepsilon=2500 \mathrm{M}^{-1} \mathrm{~cm}^{-1}\right.$ and $\lambda_{\max }=670 \mathrm{~nm}, \varepsilon=2200$ $\mathrm{M}^{-1} \mathrm{~cm}^{-1}$ ). 


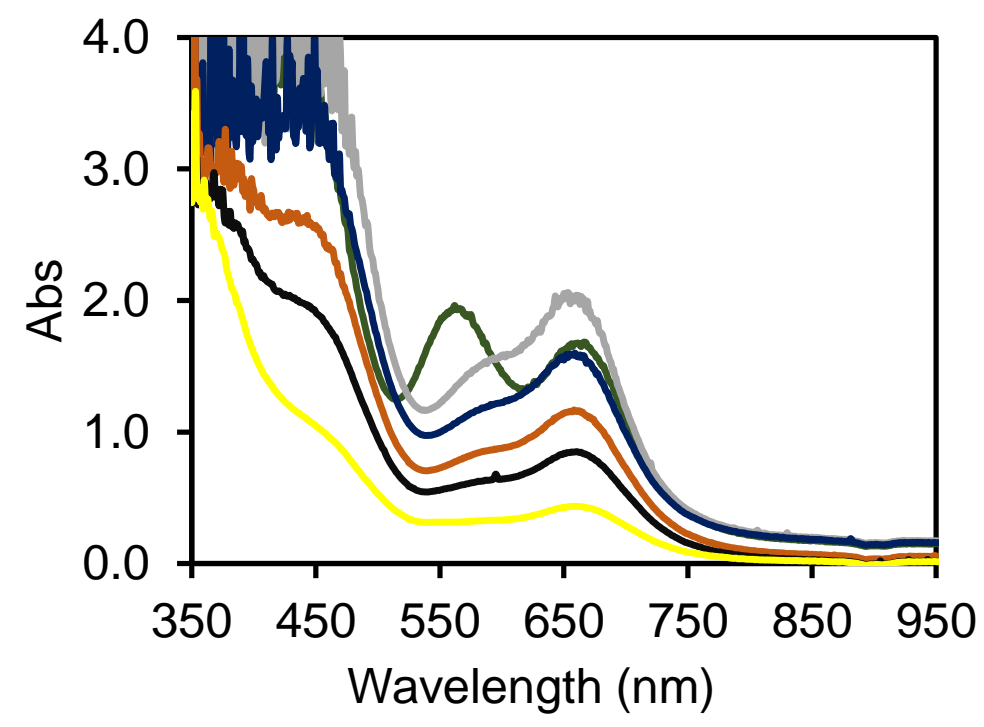

Figure S47. UV-Vis spectra of the reaction mixture of 3-Cys-BAr ${ }^{\mathrm{F}} 4$ (dark green trace at $-80{ }^{\circ} \mathrm{C}$ ) with excess acetonitrile- $d_{3}$ (gray trace at $-90{ }^{\circ} \mathrm{C}$, blue trace at $-70{ }^{\circ} \mathrm{C}$, orange trace at $-60{ }^{\circ} \mathrm{C}$, black trace at $-50{ }^{\circ} \mathrm{C}$, yellow trace at $-40{ }^{\circ} \mathrm{C}$ ).

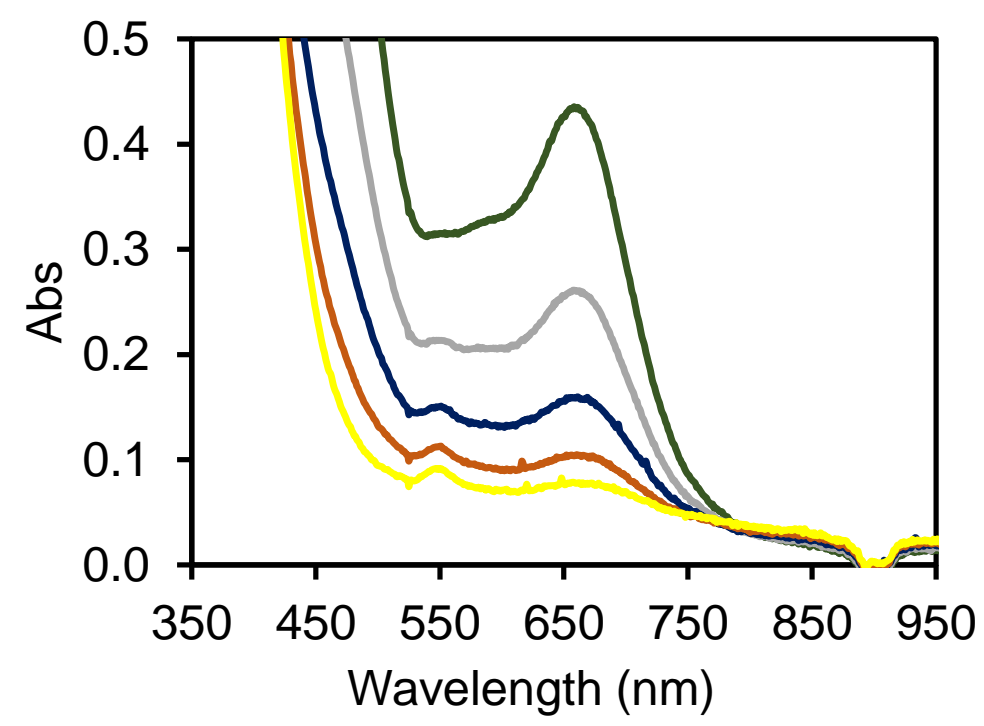

Figure S48. UV-Vis spectra of the reaction mixture of 3-Cys-BAr ${ }_{4}{ }_{4}$ with excess acetonitrile- $d_{3}$ (green trace at $-40{ }^{\circ} \mathrm{C}$, gray trace at $-30{ }^{\circ} \mathrm{C}$, blue trace at $-20^{\circ} \mathrm{C}$, brown trace at $-10{ }^{\circ} \mathrm{C}$, yellow trace at $0{ }^{\circ} \mathrm{C}$ ). 

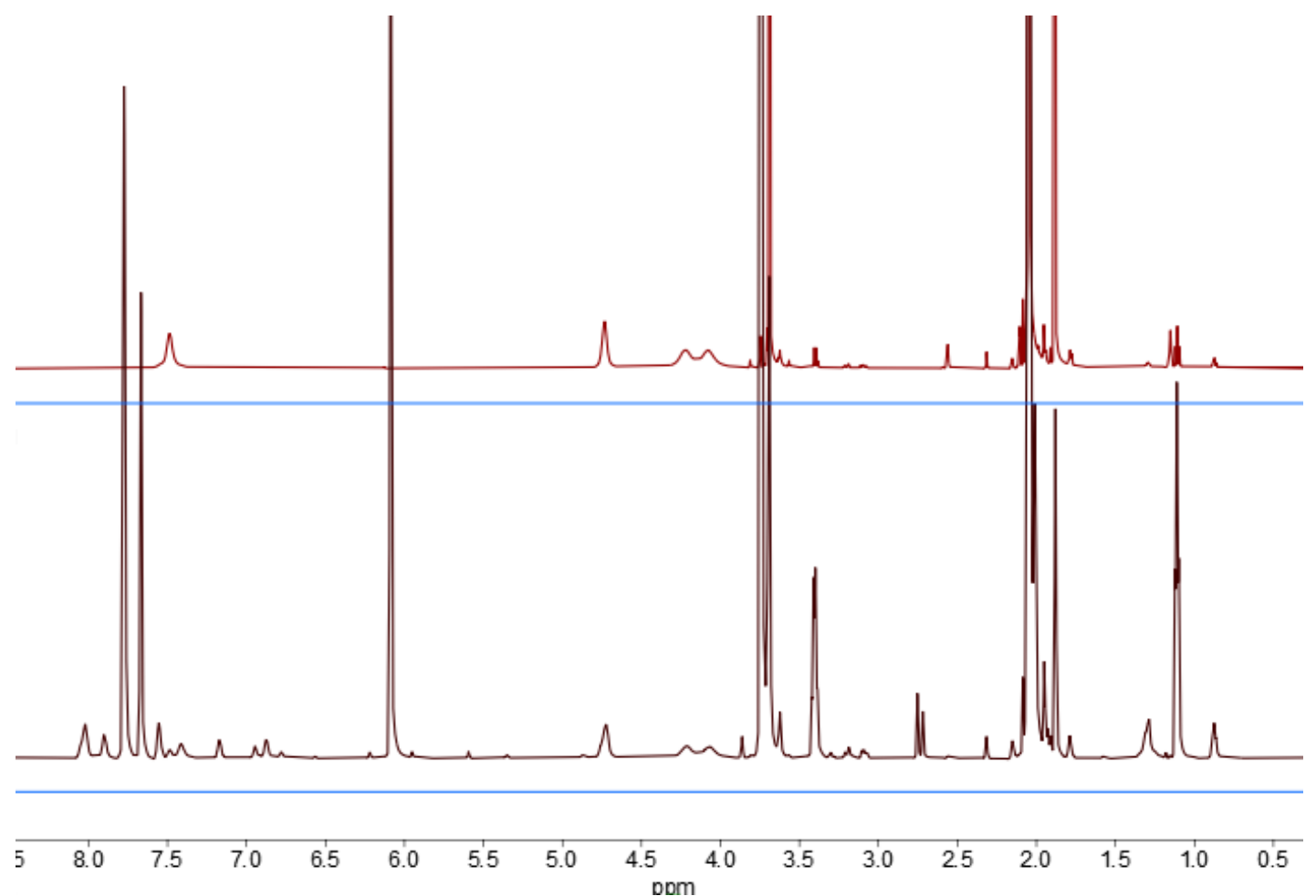

Figure S49. ${ }^{1} \mathrm{H}$ NMR $\left(600 \mathrm{MHz}\right.$, acetone- $\left.d_{6}\right)$ of free S-nitroso N-acetyl-L-cysteine methyl ester in acetone$d_{3}$ (up) and reaction mixture of $1-\mathrm{BAr}_{4}{ }_{4}$, excess $\mathrm{NO}$ with two equivalents of $\mathrm{N}$-acetyl-L-cysteine methyl ester followed by addition of excess acetonitrile- $d_{3}$ in acetone- $d_{6}$ (bottom).

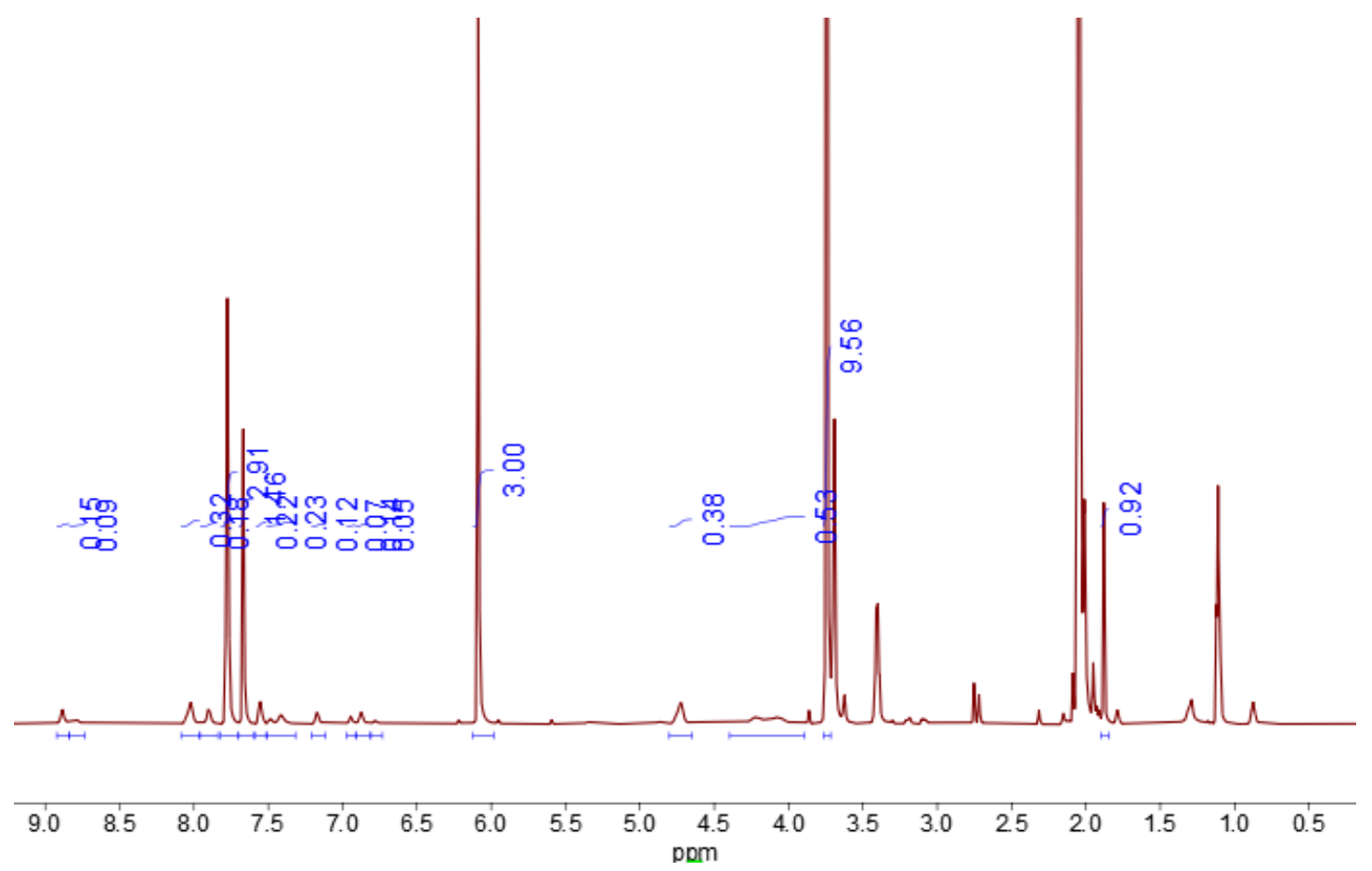

Figure S50. ${ }^{1} \mathrm{H}$ NMR $\left(600 \mathrm{MHz}\right.$, acetone- $\left.d_{6}\right)$ of 3-Cys-BAr ${ }_{4}$ and excess acetonitrile- $d_{3}$ in acetone- $d_{6}$. 
Note: The amount of internal standard 1,3,5-trimethoxybenzene used is $2.2 \mathrm{mg}(12.9 \mu \mathrm{mol})$. The amount of dicopper (I,I) precursor $1-\mathrm{BAr}_{4}{ }_{4}$ used is $5.4 \mathrm{mg}(2.25 \mu \mathrm{mol})$. The S-nitroso N-acetyl-L-cysteine methyl ester has signals at $7.49 \mathrm{ppm}, 4.73 \mathrm{ppm}, 4.21 \mathrm{ppm}, 4.07 \mathrm{ppm}, 1.88 \mathrm{ppm}$. Some of the peaks are overlapped with or very close to internal standard or solvent signals, so we used the characteristic methyl signal at 1.88 ppm to quantify the amount of S-nitrosothiol formed, that is $0.92 / 3 \times 12.9=3.96 \mu$ mol. The maximum Snitroso $\mathrm{N}$-acetyl-L-cysteine methyl ester formed is two equivalents relative to 2 - $\mathrm{BAr}_{4}{ }_{4}$, which is $2 \times 2.25=4.50 \mu \mathrm{mol}$. As a result, the yield of S-nitroso N-acetyl-L-cysteine methyl ester formation is $3.96 / 4.50=88 \%$. At the same time, the recovered dicopper(I,I) precursor $1-\mathrm{BAr}_{4} \mathrm{~F}_{4}$ has characterized signals in the aromatic area. The recovered amount of $1-\mathrm{BAr}_{4}{ }_{4}$ is $c a .0 .12 / 2 \times 12.9=0.77 \mu \mathrm{mol}$ so the recovered yield is $c a \cdot 0.77 / 2.25=34 \%$.

\section{Reaction of 1-OTf with nitric oxide in methanol}

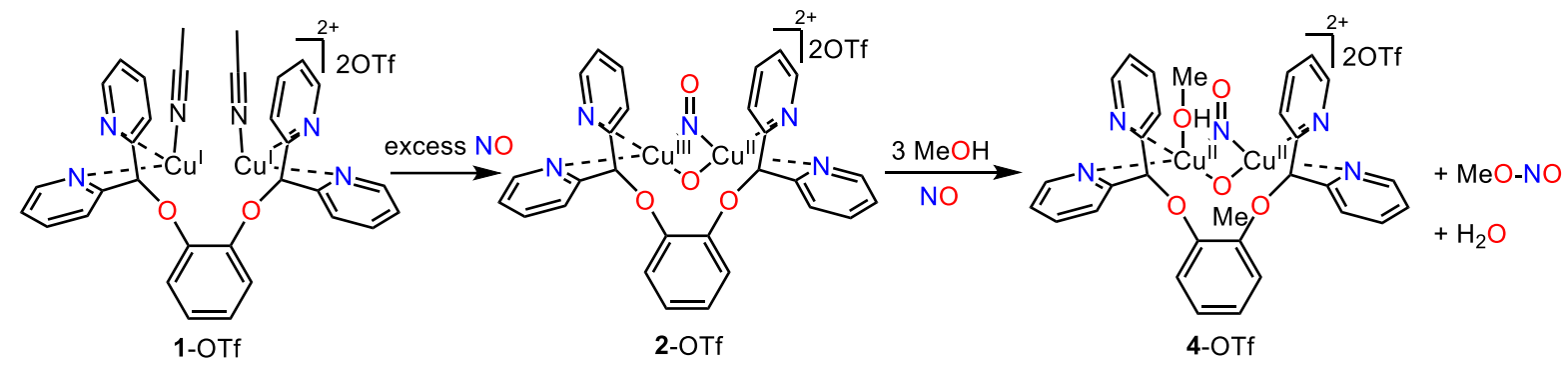

In the glovebox, a methanol solution of 1-OTf $(2.1 \mathrm{mg}, 2.3 \mu \mathrm{mol}, 3.0 \mathrm{~mL})$ was placed in a Schlenk quartz cuvette. The cuvette was sealed and connected to a three-way valve which linked both Schlenk line and nitric oxide line. The Schlenk cuvette was cooled in a dry ice/acetone bath and evacuated under vacuum to remove the nitrogen in the headspace and in the solution. The cuvette was sealed. The tubing between Schlenk cuvette and the three-way valve was then filled with pure nitric oxide (ca. $30 \mathrm{~mL}$ ). The Schlenk cuvette and tubing was then transferred to the UV-Vis spectrometer precooled at $-80{ }^{\circ} \mathrm{C}$. After the temperature stabilized, the Schlenk cuvette was opened and the NO in the tubing was allowed to diffuse into the solution. The reaction progress was monitored by taking a UV-Vis spectrum every 60 seconds. After ca. $15 \mathrm{~min}$, the cuvette was warmed up to $-70{ }^{\circ} \mathrm{C}$, then $-60{ }^{\circ} \mathrm{C},-50{ }^{\circ} \mathrm{C},-40{ }^{\circ} \mathrm{C}$ and finally $-30{ }^{\circ} \mathrm{C}$. A new dark red species $\left(\lambda_{\max }=540 \mathrm{~nm}, \varepsilon=2000 \mathrm{M}^{-1} \mathrm{~cm}^{-1}\right.$ and $\left.\lambda_{\max }=475 \mathrm{~nm}, \varepsilon=2200 \mathrm{M}^{-1} \mathrm{~cm}^{-1}\right)$ is generated which is stable below $-30^{\circ} \mathrm{C}$ (Figure S51). The single crystal of the product dicopper(II,II) $\mu$-methoxy, $\mu$ nitrosyl 4-OTf was obtained by using the above conditions to generate the product, which was then recrystallized with toluene and diethyl ether at $-40{ }^{\circ} \mathrm{C}$ in the glove box. 


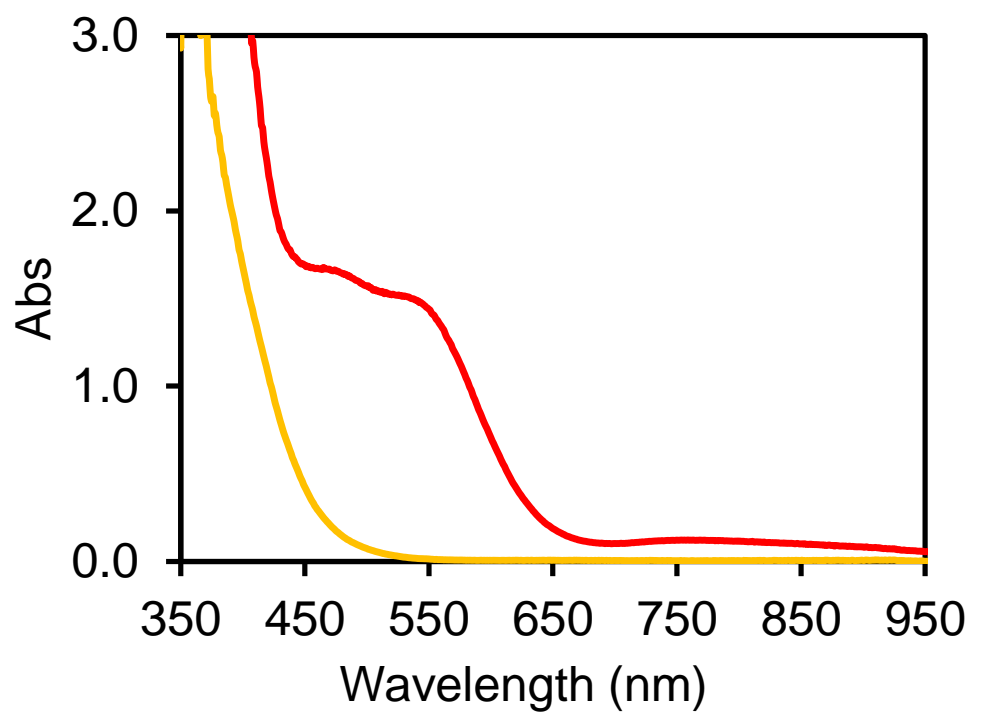

Figure S51. UV-Vis spectra of the reaction mixture of 1-OTf (yellow trace) and excess nitric oxide in methanol at $-30{ }^{\circ} \mathrm{C}$ in $0.75 \mathrm{mM}$ concentration (red trace).

\section{Reaction of 1-BAr ${ }_{4}$ with nitric oxide in methanol}

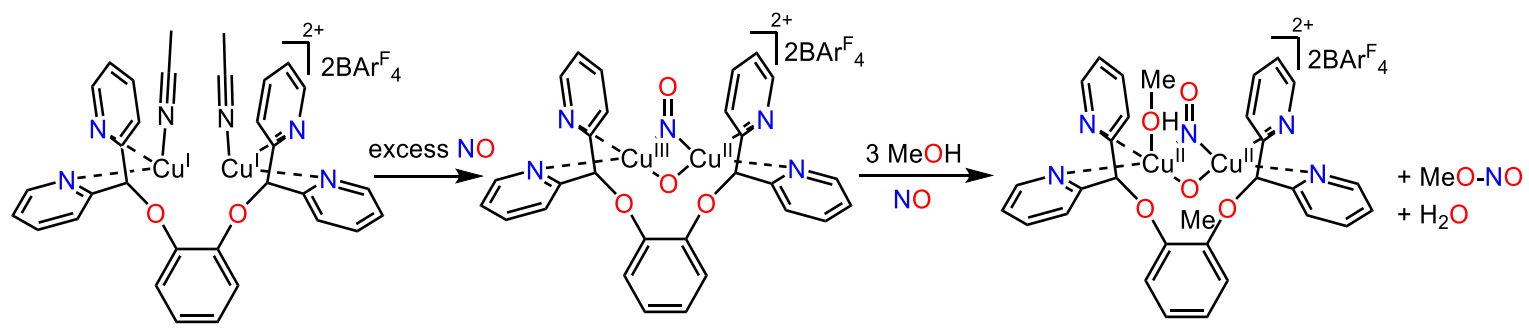

In the glovebox, a methanol solution of $1-\mathrm{BAr}_{4}(5.4 \mathrm{mg}, 2.3 \mu \mathrm{mol}, 3.0 \mathrm{~mL})$ was placed in a quartz cuvette equipped with a rubber septum. The cuvette was sealed and transferred to the UV-Vis spectrometer precooled at $-40{ }^{\circ} \mathrm{C}$. After the temperature stabilized, $\mathrm{NO}(2.0 \mathrm{~mL}, 83 \mu \mathrm{mol}, 36$ eq. $)$ was injected into the solution and the reaction progress was monitored by taking a UV-Vis spectrum every 60 seconds. After $c a$. $20 \mathrm{~min}$, the spectrum stabilized. Additional NO $(1.0 \mathrm{~mL}, 42 \mu \mathrm{mol}, 18 \mathrm{eq})$ was injected to the solution and the reaction progress was monitored by taking a UV-Vis spectrum every 60 seconds. After $c a$. 30 min, additional NO $(2.0 \mathrm{~mL}, 83 \mu \mathrm{mol}, 36$ eq.) was injected into the solution and the reaction was monitored at this temperature by taking UV-Vis spectrum every 60 seconds until the $480 \mathrm{~nm}$ and $540 \mathrm{~nm}$ bands stabilized. The cuvette was warmed up to $-30{ }^{\circ} \mathrm{C}$ and the spectra did not change. A new dark red species $\left(\lambda_{\max }=540 \mathrm{~nm}, \varepsilon=2000 \mathrm{M}^{-1} \mathrm{~cm}^{-1}\right.$ and $\left.\lambda_{\max }=475 \mathrm{~nm}, \varepsilon=2200 \mathrm{M}^{-1} \mathrm{~cm}^{-1}\right)$ was generated which is stable below $-30^{\circ} \mathrm{C}$ (Figure S52). The product spectrum is compared with that from 1-OTf and excess nitric oxide in methanol at $-30{ }^{\circ} \mathrm{C}$ (Figure S51) in Figure S53, suggesting both 1-B $\mathrm{Ar}^{\mathrm{F}}{ }_{4}$ and 1-OTf can perform the same reductive nitric oxide coupling reaction followed by protonation of $\mu$-oxo moiety with methanol and further reductive $O$-nitrosation, affording methyl nitrite as the byproduct. To support our hypothesis, we 
also tried the above reaction at $0.20 \mathrm{mM}$ concentration level to observe the diagnostic "five-finger" features of alkyl nitrite in UV-Vis.

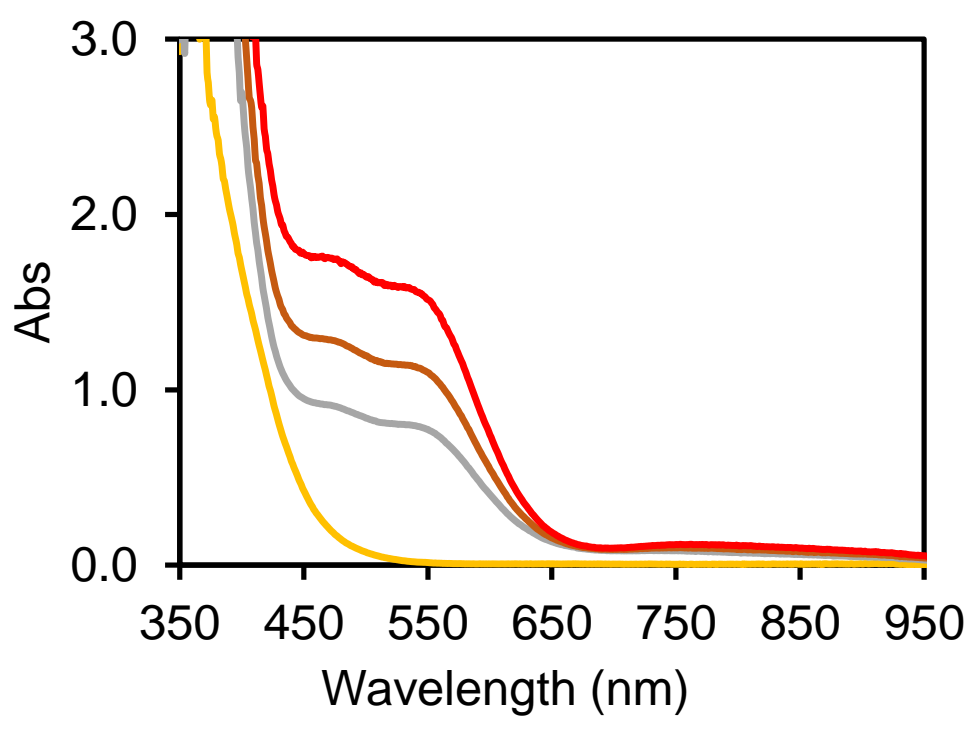

Figure S52. UV-Vis spectra of the reaction mixture of $1-\mathrm{BAr}_{4}{ }_{4}$ (yellow trace) and nitric oxide in methanol at $-30{ }^{\circ} \mathrm{C}$ (gray trace with 36 eq. NO, brown trace with 54 eq. NO and finally dark red trace with 90 eq NO).

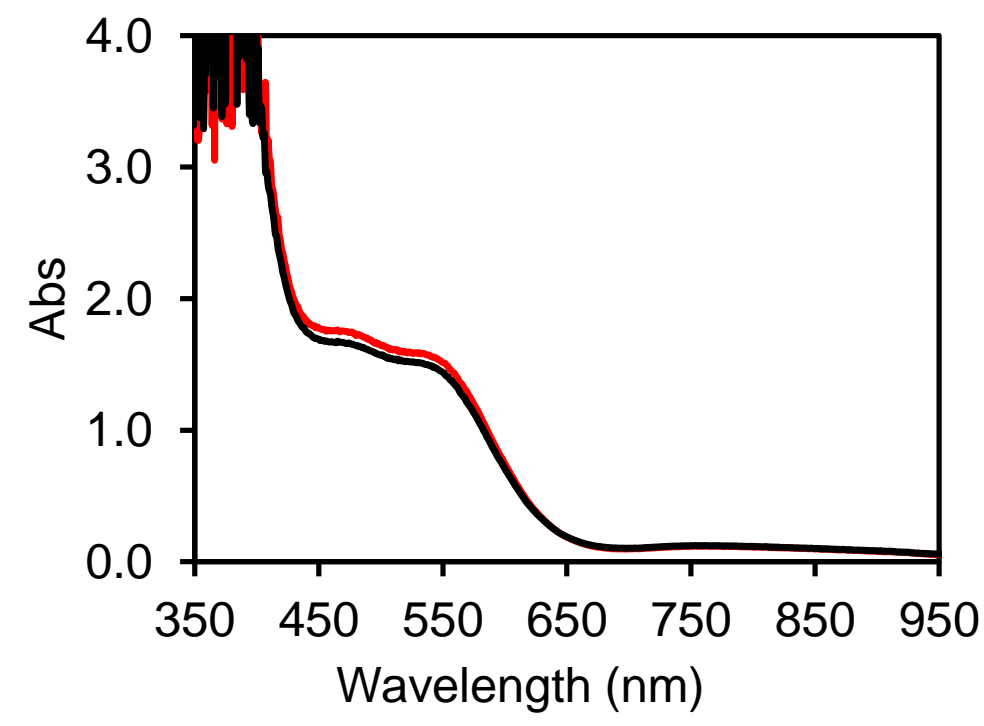

Figure S53. UV-Vis spectra of the reaction mixture of $\mathbf{1}$ and excess amount of nitric oxide in methanol at $-30{ }^{\circ} \mathrm{C}$ (black trace with OTf anion and red trace with $\mathrm{BAr}^{\mathrm{F}}{ }_{4}$ counter anion). 


\section{Reaction of 1-BAr ${ }_{4}$ with nitric oxide in methanol at $0.20 \mathrm{mM}$ concentration}

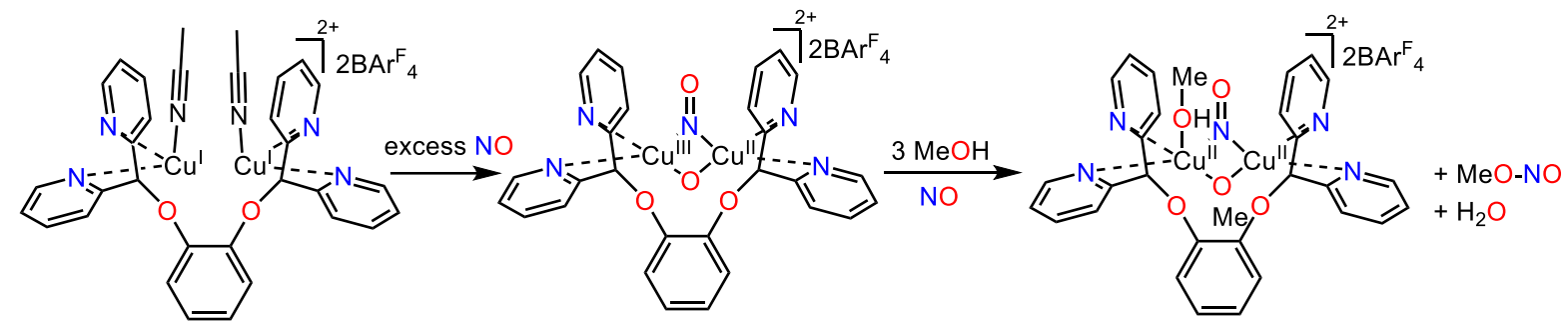

In the glovebox, a methanol solution of $1-\mathrm{BAr}_{4}{ }_{4}(1.4 \mathrm{mg}, 0.59 \mu \mathrm{mol}, 3.0 \mathrm{~mL}, 0.20 \mathrm{mM})$ was placed in a quartz cuvette equipped with a rubber septum. The cuvette was sealed and transferred to the UV-Vis spectrometer precooled at $-40{ }^{\circ} \mathrm{C}$. After the temperature stabilized, NO $(2.0 \mathrm{~mL}, 83 \mu \mathrm{mol}, 140$ eq. $)$ was injected into the solution and the reaction progress was monitored by taking UV-Vis spectrum every 60 seconds. After ca. $30 \mathrm{~min}$, the spectrum stabilized. Additional NO $(2.5 \mathrm{~mL}, 104 \mu \mathrm{mol}, 176 \mathrm{eq})$ was injected to the solution and the reaction progress was monitored by taking UV-Vis spectrum every 60 seconds until the $480 \mathrm{~nm}$ and $540 \mathrm{~nm}$ bands stabilized. The cuvette was warmed up to $-30{ }^{\circ} \mathrm{C}$ and the spectra did not change. The new dark red species $\left(\lambda_{\max }=540 \mathrm{~nm}, \varepsilon=2000 \mathrm{M}^{-1} \mathrm{~cm}^{-1}\right.$ and $\left.\lambda_{\max }=475 \mathrm{~nm}, \varepsilon=2200 \mathrm{M}^{-1} \mathrm{~cm}^{-1}\right)$ was reproduced at this concentration (Figure S54). In this case, we observed the diagnostic "five-finger" features of alkyl nitrite in UV-Vis spectrum. Based on this experiment and the single crystal structure of dicopper(II,II) $\mu$-methoxy, $\mu$-nitrosyl 4-OTf, we concluded that when methanol was used as the substrate in this system, stepwise $O$-nitrosation reaction occurs in contrast to the fully S-nitrosation reaction with primary thiols and thiophenols.

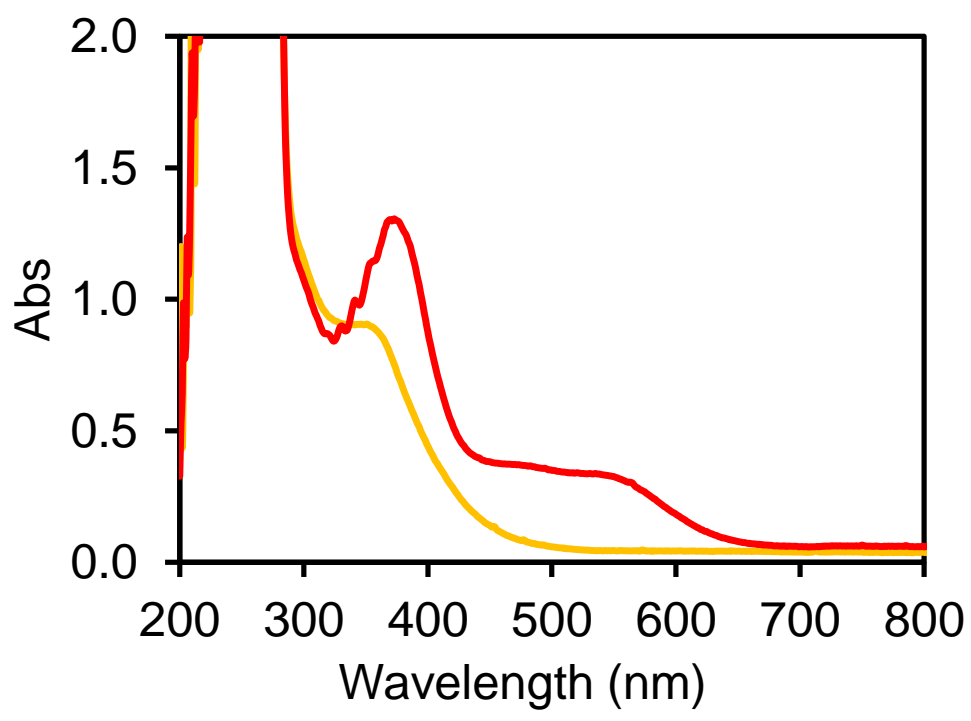

Figure S54. UV-Vis spectra of the reaction mixture of 1-BAr ${ }_{4}$ (yellow trace) and excess nitric oxide in methanol at $-30{ }^{\circ} \mathrm{C}$ in $0.20 \mathrm{mM}$ concentration (red trace). 


\section{Reaction of 2-BAr ${ }_{4}$ with methanol}
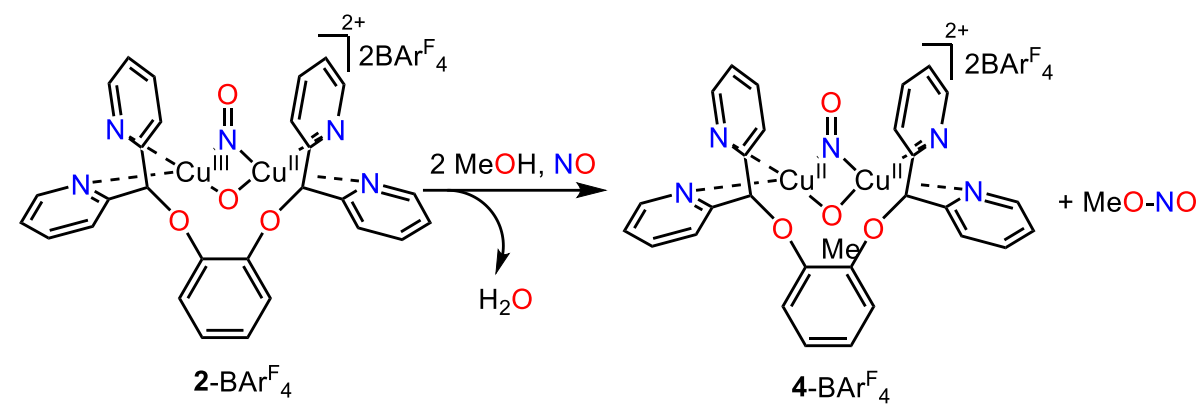

In the glovebox, a solution of $1-\mathrm{BAr}^{\mathrm{F}}(5.4 \mathrm{mg}, 2.3 \mu \mathrm{mol}, 3.0 \mathrm{~mL})$ in a 1:1 mixture of DCM and THF was placed in a quartz cuvette equipped with a rubber septum. The cuvette was sealed and transferred to the $\mathrm{UV}-\mathrm{V}$ is spectrometer precooled at $-40{ }^{\circ} \mathrm{C}$. After the temperature stabilized, $\mathrm{NO}(2.0 \mathrm{~mL}, 83 \mu \mathrm{mol}, 37 \mathrm{eq}$.) was injected into the solution and the reaction progress was monitored by taking UV-Vis spectrum every 60 seconds. After ca. $90 \mathrm{~min}$, the spectra with diagnostic 2-BAr${ }_{4}{ }_{4}$ band $\left(\lambda_{\max }=530 \mathrm{~nm}, \varepsilon=2300 \mathrm{M}^{-1} \mathrm{~cm}^{-1}\right)$ stabilized. Methanol $(0.10 \mathrm{~mL}, 2.47 \mathrm{mmol}, 1100 \mathrm{eq})$ was injected into the solution and the reaction progress was monitored at this temperature by taking UV-Vis spectra every 60 seconds. Similar to the reaction of 1$\mathrm{BAr}_{4}{ }_{4}$ with NO in pure methanol in Figure S49, a dark red species $\left(\lambda_{\max }=475 \mathrm{~nm}, \varepsilon=2200 \mathrm{M}^{-1} \mathrm{~cm}^{-1}\right.$ and $\lambda_{\max }=530 \mathrm{~nm}, \varepsilon=2300 \mathrm{M}^{-1} \mathrm{~cm}^{-1}$ ) was generated (Figure S55). This species is stable below $-30{ }^{\circ} \mathrm{C}$. To further corroborate that $4-\mathrm{BAr}_{4}{ }_{4}$ would be directly formed by complex $1-\mathrm{B} \mathrm{Ar}^{\mathrm{F}}{ }_{4}$ with $\mathrm{NO}$ in the same solvents, we performed the following reaction.

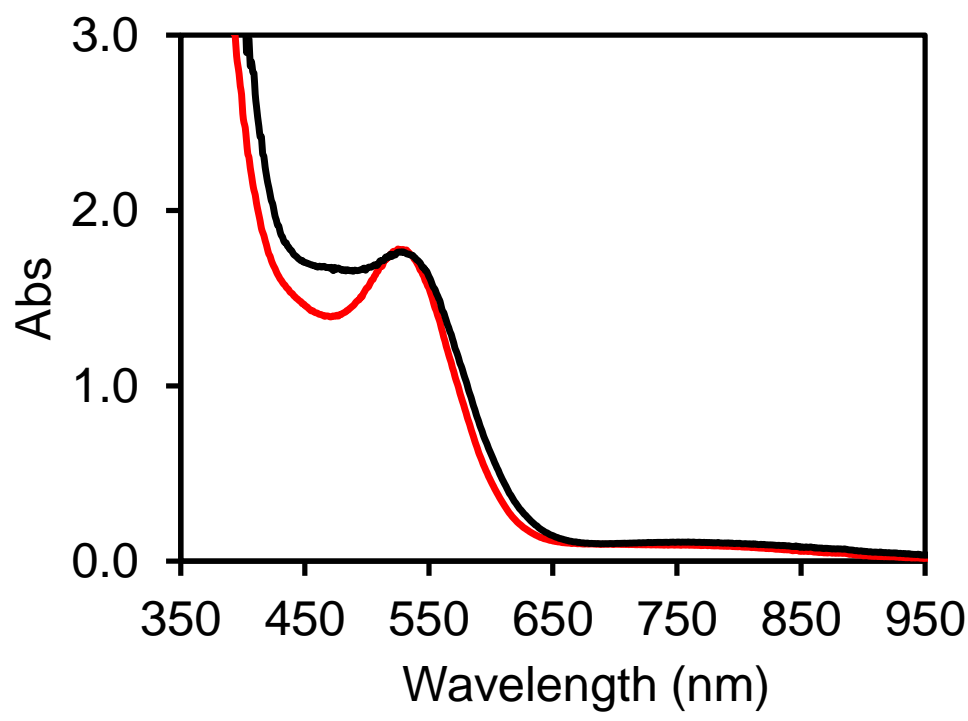

Figure S55. UV-Vis spectra of the reaction mixture of $2-\mathrm{BAr}_{4}{ }_{4}$ (red trace) and 1100 equivalents of methanol (black trace) at $-40{ }^{\circ} \mathrm{C}$. 


\section{Reaction of 1-BAr ${ }_{4}$ with nitric oxide in mixed solvent}
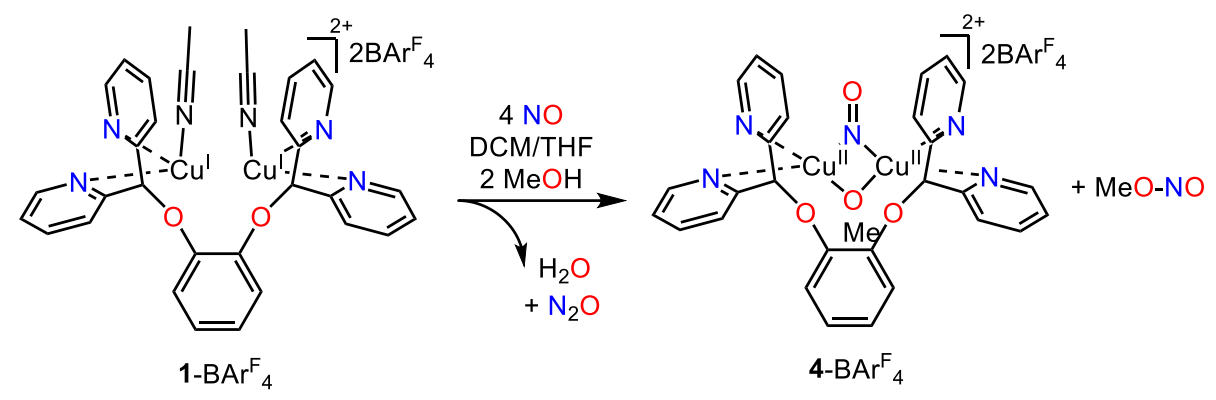

In the glovebox, a solution of $1-\mathrm{BAr}_{4}{ }_{4}(5.4 \mathrm{mg}, 2.3 \mu \mathrm{mol})$ in a 1:1 mixture of DCM (1.5 mL) and THF (1.5 $\mathrm{mL})$ together with methanol $(0.10 \mathrm{~mL}, 2.47 \mathrm{mmol}, 1100 \mathrm{eq})$ was placed in a quartz cuvette equipped with a rubber septum. The cuvette was sealed and transferred to the UV-Vis spectrometer precooled at $-40{ }^{\circ} \mathrm{C}$. After the temperature stabilized, NO $(2.0 \mathrm{~mL}, 83 \mu \mathrm{mol}, 36$ eq. $)$ was injected into the solution and the reaction progress was monitored by taking UV-Vis spectrum every 60 seconds. After $c a$. 60 min, very similar spectra with diagnostic 4-B $\operatorname{Ar}_{4}{ }_{4}$ bands $\left(\lambda_{\max }=475 \mathrm{~nm}, \varepsilon=2000 \mathrm{M}^{-1} \mathrm{~cm}^{-1}\right.$ and $\lambda_{\max }=530 \mathrm{~nm}, \varepsilon=2000$ $\mathrm{M}^{-1} \mathrm{~cm}^{-1}$ ) was observed (Figure S56). This spectrum is compared with that from the reaction of $2-\mathrm{BAr}_{4}{ }_{4}$ with methanol in the same mixed solvent in Figure S57, which further supports that 4-BAr ${ }_{4}$ is formed by the reaction of methanol with dicopper $\mu$-oxo, $\mu$-nitrosyl intermediate 2 - $\mathrm{BAr}_{4}{ }_{4}$ probably through protonation of $2-\mathrm{BAr}_{4}$ with two equivalents of methanol followed by stepwise reductive $O$-nitrosation. These reaction conditions do not require a large excess amount of nitric oxide. As a result, these conditions were used for in-situ IR experiments to investigate the NO stretch of 4.

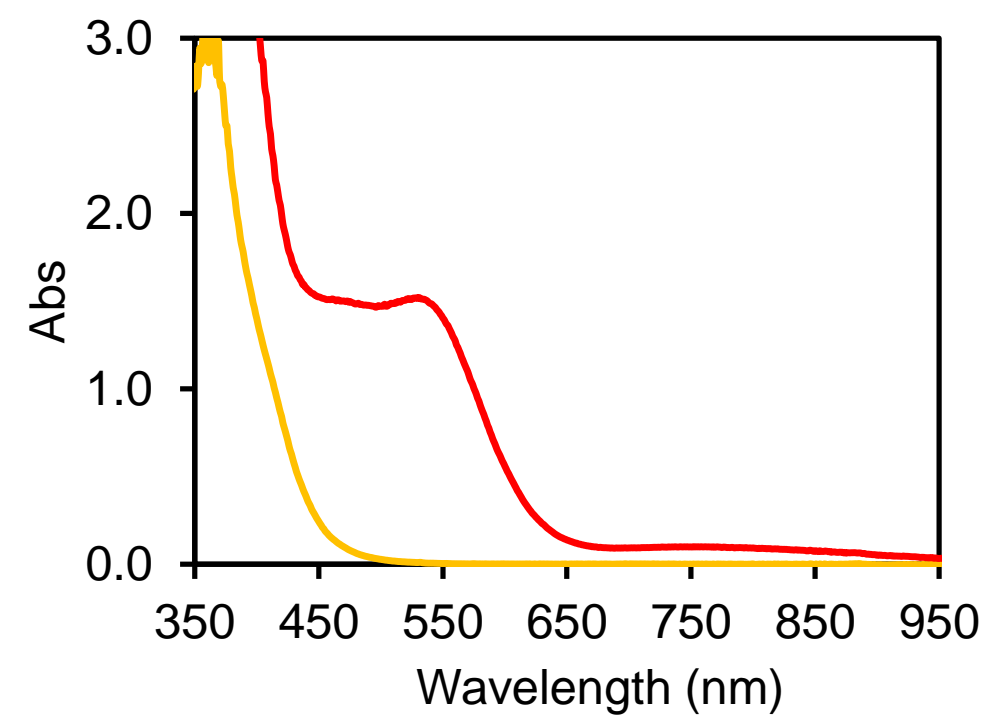

Figure S56. UV-Vis spectra of the reaction mixture of $1-\mathrm{BAr}_{4}{ }_{4}$ (yellow trace) and excess NO in the presence of 1100 equivalents of methanol in a 1:1 mixture of DCM and THF (red trace) at $-40{ }^{\circ} \mathrm{C}$. 


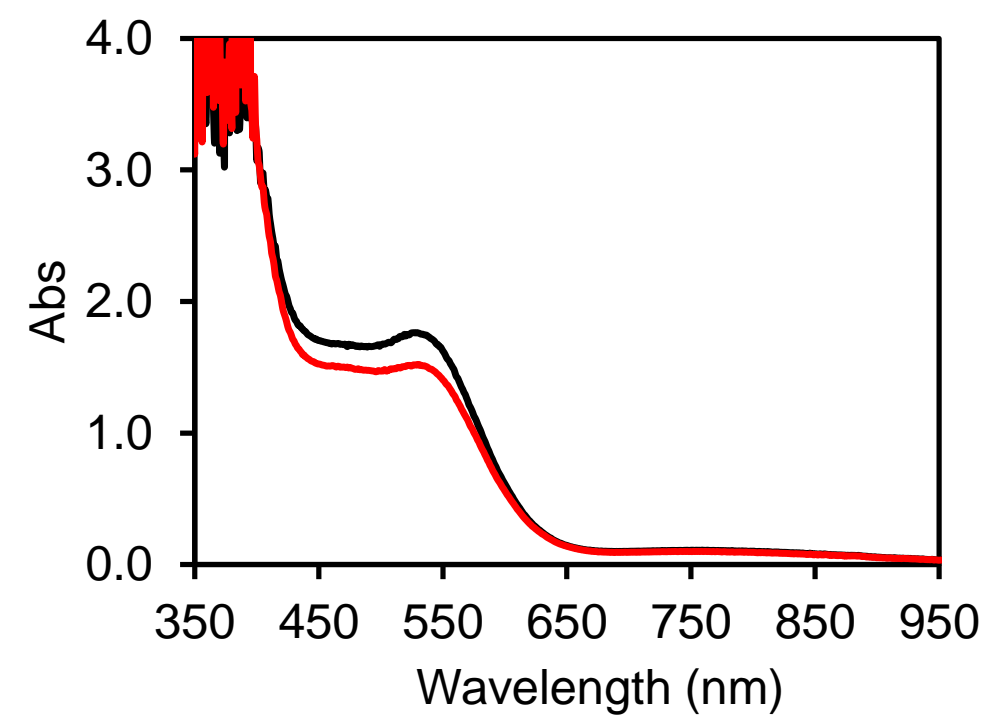

Figure S57. UV-Vis spectra of the reaction mixture of 1-BAr ${ }_{4}$ and excess NO in the presence of 1100 equivalents of methanol in a 1:1 mixture of DCM and THF (red trace) at $-40{ }^{\circ} \mathrm{C}$ compared with that from the reaction of $2-\mathrm{BAr}_{4}{ }_{4}$ and 1100 equivalents of methanol in the same solvent at $-40{ }^{\circ} \mathrm{C}$ (black trace).

\section{Reaction of 2-BAr ${ }_{4}{ }_{4}$ with 2-phenylethanethiolate}

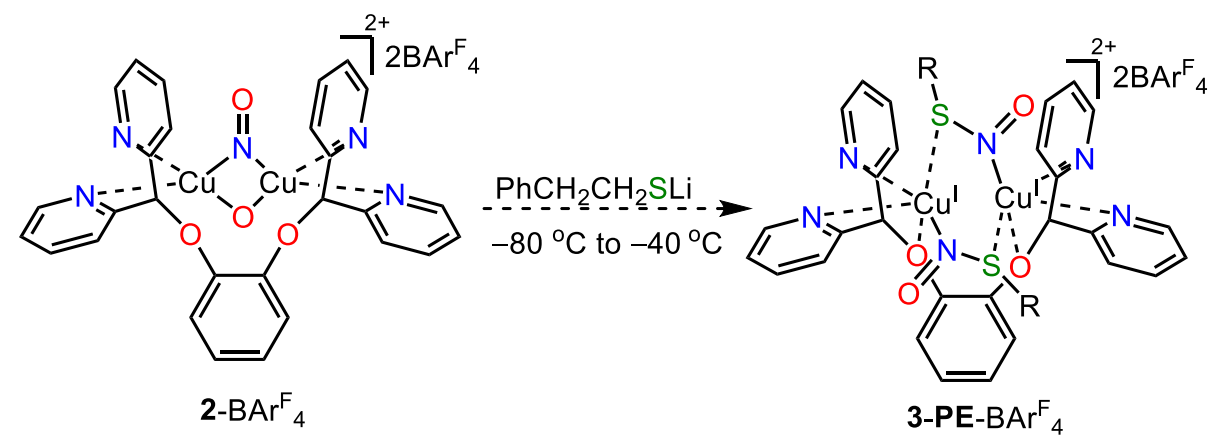

In the glovebox, a solution of $1-\mathrm{BAr}_{4}{ }_{4}(5.4 \mathrm{mg}, 2.3 \mu \mathrm{mol})$ in a mixture of acetone $(1.5 \mathrm{~mL})$ and THF $(1.4$ $\mathrm{mL})$ was placed in a quartz cuvette equipped with a rubber septum. The cuvette was sealed and transferred to the UV-Vis spectrometer precooled at $-40{ }^{\circ} \mathrm{C}$. After the temperature stabilized, NO $(2.0 \mathrm{~mL}, 83 \mu \mathrm{mol}$, 36 eq.) was injected into the solution and the reaction progress was monitored by taking a UV-Vis spectrum every 60 seconds. After $c a .30 \mathrm{~min}$, dicopper $\mu$-oxo, $\mu$-nitrosyl intermediate $2-\mathrm{BAr}^{\mathrm{F}}{ }_{4}$ band $\left(\lambda_{\max }=530 \mathrm{~nm}\right.$, $\varepsilon=2400 \mathrm{M}^{-1} \mathrm{~cm}^{-1}$ ) stabilized. The cuvette was cooled to $-60{ }^{\circ} \mathrm{C}$ and stabilized before 2phenylethanethiolate $(0.10 \mathrm{~mL}, 22.5 \mathrm{mM}$ in THF, $2.3 \mu \mathrm{mol})$ was injected into the above solution. Different from the reaction of $2-\mathrm{BAr}_{4}$ with 2-phenylethanethiol, we observed that the $530 \mathrm{~nm}$ band decayed gradually, while no new $\mathrm{Cu}(\mathrm{I})-S$-nitrosothiol charge transfer bands near $580 \mathrm{~nm}$ and $690 \mathrm{~nm}$ were observed (Figure S58). This experiment suggests that protonation of the $\mu$-oxo moiety is essential for the following reductive S-nitrosation. 


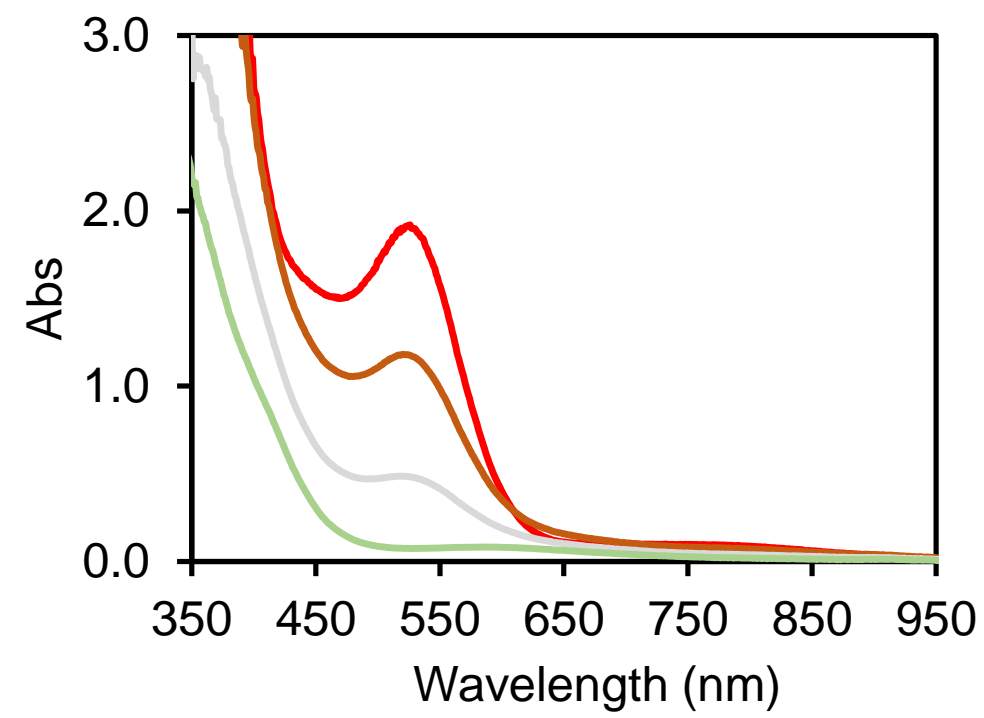

Figure S58. UV-Vis spectra of the reaction mixture of $2-\mathrm{BAr}_{4}{ }_{4}$ (red trace) and one equivalent of 2phenylethanethiolate (brown trace at $-60{ }^{\circ} \mathrm{C}$, gray trace at $-50{ }^{\circ} \mathrm{C}$ and light green trace at $-40{ }^{\circ} \mathrm{C}$ ).

\section{${ }^{15} \mathrm{~N}$ NMR characterization of proposed dicopper(I,I) di-S-nitrosothiol}

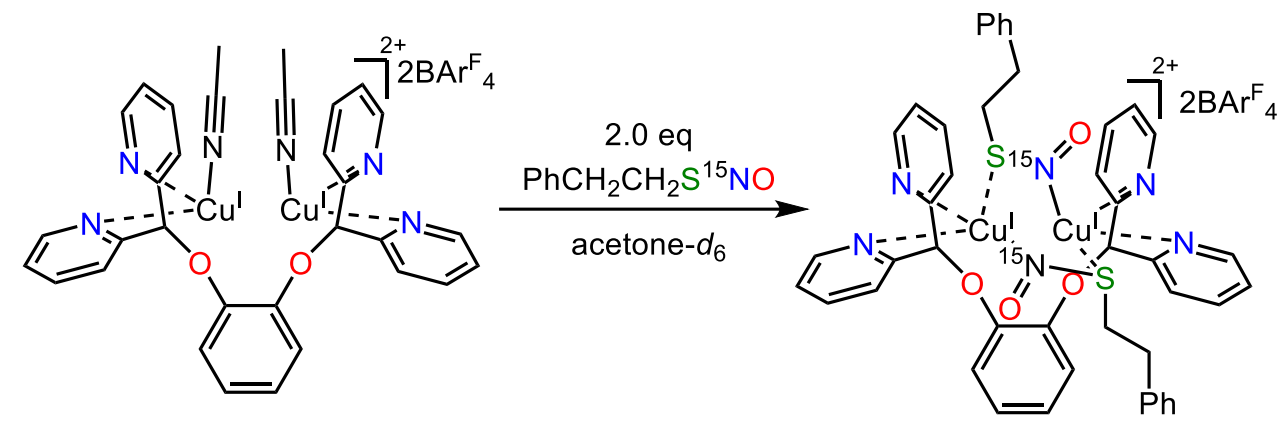

In the glovebox, $1-\mathrm{BAr}_{4}{ }_{4}(183 \mathrm{mg}, 76.8 \mu \mathrm{mol})$ was dissolved in acetone- $d_{6}(320 \mu \mathrm{L})$ to make a $240 \mathrm{mM}$ solution. $\mathrm{PhCH}_{2} \mathrm{CH}_{2} \mathrm{~S}^{15} \mathrm{NO}(48.4 \mathrm{mg}, 288 \mu \mathrm{mol})$ was dissolved in acetone- $d_{6}(200 \mu \mathrm{L})$ to make a $1440 \mathrm{mM}$ solution in the dark. The above acetone- $d_{6}$ solution of $1-\mathrm{BAr}_{4}{ }_{4}(240 \mathrm{mM}, 0.300 \mathrm{~mL}, 72 \mu \mathrm{mol})$ was transferred into an NMR tube with a screw cap and septum seal. The NMR tube was sealed and transferred out of the glove box and connected to a Schlenk adapter through a rubber septum. The Schlenk adapter was evacuated under vacuum and refilled with nitrogen. The vacuum/refill cycle was repeated five times. The bottom of the NMR tube ( $c a .5 .0 \mathrm{~cm}$ long) was cooled in a dry ice/acetone bath for at least 20 min before the above $\mathrm{PhCH}_{2} \mathrm{CH}_{2} \mathrm{~S}^{15} \mathrm{NO}$ solution in acetone- $d_{6}(1440 \mathrm{mM}, 0.120 \mathrm{~mL}, 173 \mu \mathrm{mol}, 2.4 \mathrm{eq})$ was injected into the NMR tube dropwise through the septum under positive nitrogen flow. The NMR tube was then sealed quickly with parafilm under positive nitrogen flow and transferred to a $-75^{\circ} \mathrm{C}$ cold bath. After $\mathrm{ca}$. $15 \mathrm{~min}$, the NMR tube was shaken quickly for $c a .5$ seconds and put back to $-75^{\circ} \mathrm{C}$ cold bath. These procedures were repeated 5 times to help mix the two substrates as the mixture is very viscous at $-75{ }^{\circ} \mathrm{C}$. 
The cold NMR tube was transferred to the NMR instrument with the probe pre-cooled at $-80{ }^{\circ} \mathrm{C} .{ }^{15} \mathrm{~N}$ NMR spectrum was collected at $-80^{\circ} \mathrm{C}$ (Figure S59).
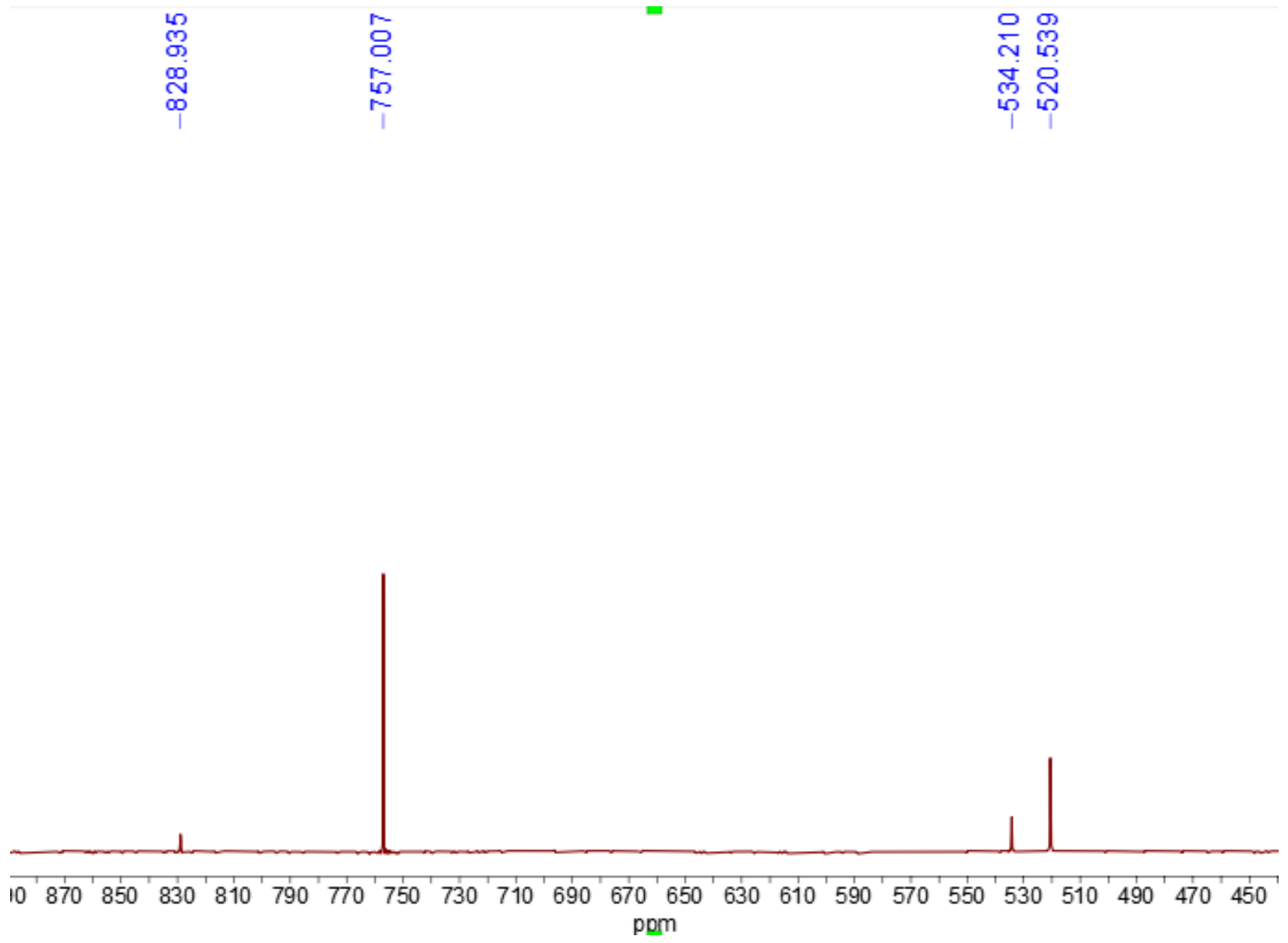

Figure S59: ${ }^{15} \mathrm{~N}$ NMR (61 MHz, acetone- $\left.d_{6}\right)$ spectrum of reaction mixture of 1-BArF ${ }_{4}$ with 2.4 eq of $\mathrm{PhCH}_{2} \mathrm{CH}_{2} \mathrm{~S}^{15} \mathrm{NO}$ at $-80{ }^{\circ} \mathrm{C}$. The ${ }^{15} \mathrm{~N}$ chemical shift is referenced to $\mathrm{NH}_{3}(0 \mathrm{ppm})$. 


\section{Solvent effect on $S$-nitroso-2-phenylethanethiol binding to dicopper(I,I) complex}

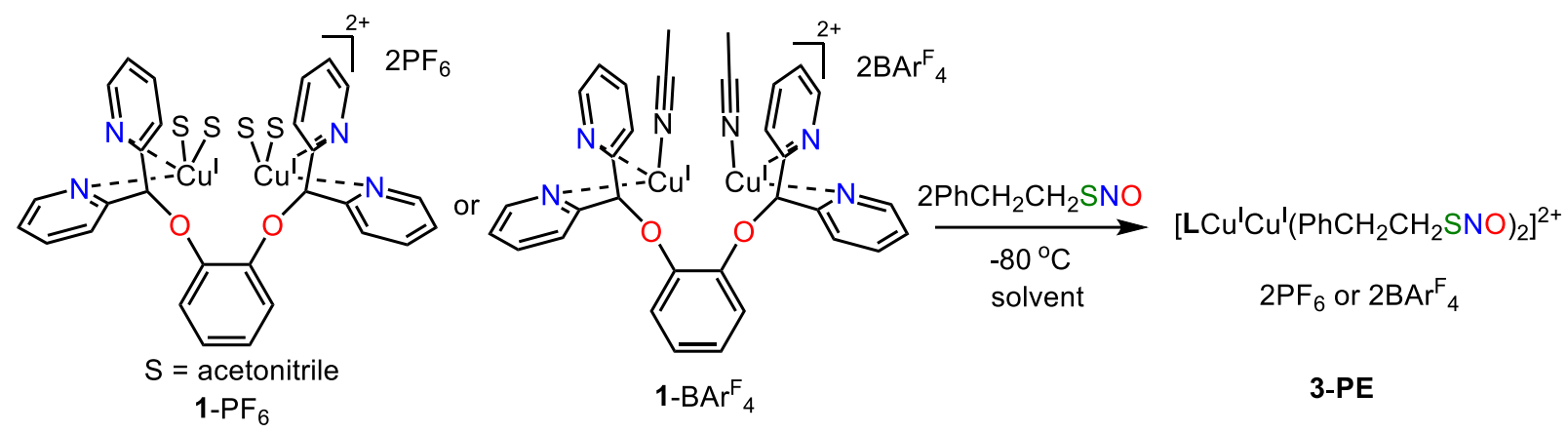

In the glovebox, a diethyl ether solution of $1-\mathrm{BAr}_{4}^{\mathrm{F}}(5.4 \mathrm{mg}, 2.3 \mu \mathrm{mol}, 2.80 \mathrm{~mL})$ was placed in a quartz cuvette equipped with a rubber septum. The cuvette was sealed and transferred to the UV-Vis spectrometer precooled at $-80{ }^{\circ} \mathrm{C}$. After the temperature stabilized, $\mathrm{PhCH}_{2} \mathrm{CH}_{2} \mathrm{SNO}(0.20 \mathrm{~mL}, 22.5 \mathrm{mM}$ in diethyl ether, $4.5 \mu \mathrm{mol}, 2.0$ equiv.) was injected to the solution, and the reaction progress was monitored by taking a UVvis spectrum every 60 seconds. A new green species $\left(\lambda_{\max }=595 \mathrm{~nm}, \varepsilon=1900 \mathrm{M}^{-1} \mathrm{~cm}^{-1}\right.$ and $\lambda_{\max }=645 \mathrm{~nm}$, $\varepsilon=2200 \mathrm{M}^{-1} \mathrm{~cm}^{-1}$ ) is generated (Figure S60, green trace). The product spectrum in diethyl ether solvent is compared to that derived from 1-B $\mathrm{Ar}_{4}{ }_{4}$ and two equivalents of $\mathrm{PhCH}_{2} \mathrm{CH}_{2} \mathrm{SNO}$ in acetone (Figure S60, gray trace), THF (Figure S60, black trace) and $1-\mathrm{PF}_{6}$ with two equivalents of $\mathrm{PhCH}_{2} \mathrm{CH}_{2} \mathrm{SNO}$ in DCM (Figure S60, red trace) at the same concentration.

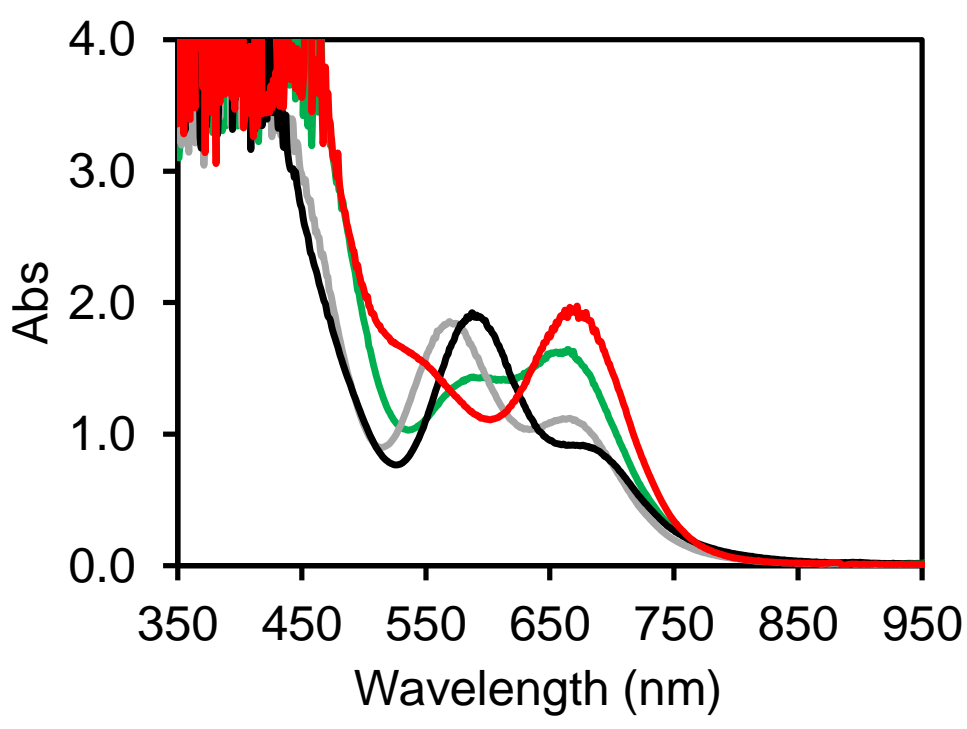

Figure S60. Experimental spectra of 3-PE from reaction mixture of dicopper(I,I) precursor 1 and two equivalents of $\mathrm{PhCH}_{2} \mathrm{CH}_{2} \mathrm{SNO}$ in different solvents at $-80{ }^{\circ} \mathrm{C}$ (red trace, DCM; green trace, diethyl ether; black trace, tetrahydrofuran; gray trace, acetone.) 


\section{X-ray Crystallographic Data}

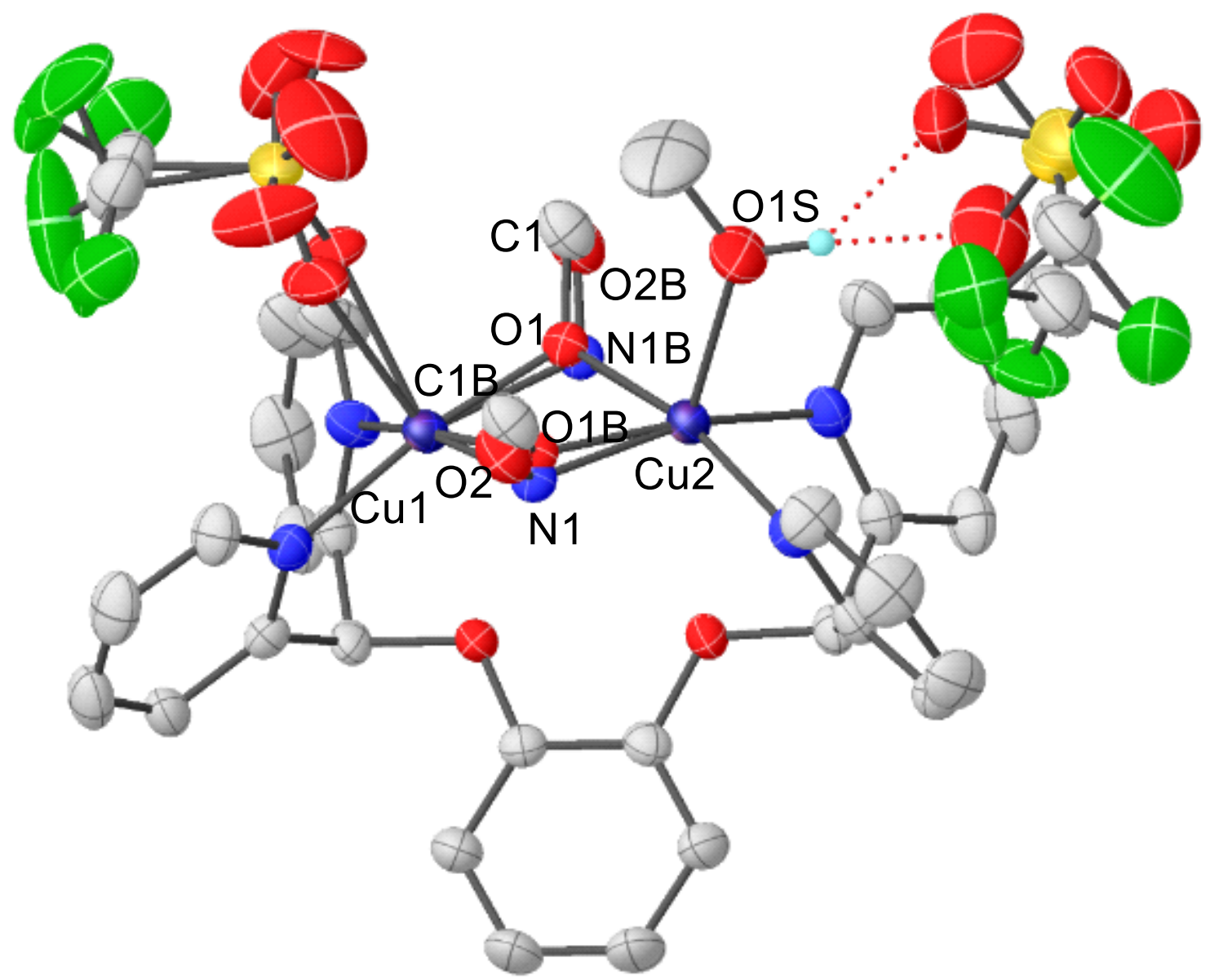

Figure S61: X-ray structure of 4-OTf with thermal ellipsoids of 50\% probability. Hydrogen atoms are omitted for clarity except for one with hydrogen bonding. Selected bond lengths $(\AA)$ and angles $\left({ }^{\circ}\right)$ for 4-OTf: $\mathrm{Cu} 1-\mathrm{N} 1=1.976(16), \mathrm{Cu} 2-\mathrm{N} 1=2.00(3), \mathrm{Cu} 1-\mathrm{O} 1=1.871(15), \mathrm{Cu} 2-\mathrm{O} 1=1.950(13), \mathrm{N} 1-\mathrm{O} 2=$ 1.32(5), N1B-O2B = 1.27(4), Cu1-N1-Cu2 = 97.1(12), Cu2-O1S = 2.227(3). 
Table S1: Crystal Data and Structure Refinement for Complexes.

\begin{tabular}{|c|c|}
\hline & 4 \\
\hline $\mathrm{CCDC}$ & \\
\hline Empirical formula, FW (g/mol) & $\mathrm{C}_{35.50} \mathrm{H}_{33} \mathrm{Cu}_{2} \mathrm{~F}_{6} \mathrm{~N}_{5} \mathrm{O}_{11} \mathrm{~S}_{2}, 1010.87$ \\
\hline Color & Red \\
\hline Temperature (K) & 150 \\
\hline Wavelength $(\AA)$ & 0.71073 \\
\hline Crystal system, Space group & Triclinic, $\mathrm{P}-1$ \\
\hline Unit cell dimensions a $(\AA)$ & $10.1398(11)$ \\
\hline $\mathrm{b}(\AA)$ & $13.6935(16)$ \\
\hline c $(\AA)$ & $14.7211(17)$ \\
\hline$\alpha\left(^{\circ}\right)$ & $95.640(4)$ \\
\hline$\beta\left(^{\circ}\right)$ & $92.763(4)$ \\
\hline$\gamma\left(\left(^{\circ}\right)\right.$ & $93.199(4)$ \\
\hline Volume $\left(\AA^{3}\right)$ & $2028.0(4)$ \\
\hline $\mathrm{Z}$ & 2 \\
\hline Density (calc., g/cm ${ }^{-3}$ ) & 1.655 \\
\hline Absorption coefficient $\left(\mathrm{mm}^{-1}\right)$ & 1.244 \\
\hline$F(000)$ & 1026 \\
\hline Theta range for data collection $\left(^{\circ}\right)$ & 2.785 to 26.394 \\
\hline Index ranges & $-12<=\mathrm{h}<=12,-17<=\mathrm{k}<=17,-18<=\mathrm{l}<=18$ \\
\hline Reflections collected & 77507 \\
\hline Independent reflections, $\mathrm{R}_{\text {int }}$ & $8302[\mathrm{R}(\mathrm{int})=0.0644, \mathrm{R}($ sigma $)=0.0356]$ \\
\hline Completeness to $\theta_{\max }(\%)$ & 99.8 \\
\hline Absorption correction & Semi-empirical from equivalents \\
\hline Refinement method & Full-matrix least-squares on $\mathrm{F}^{2}$ \\
\hline
\end{tabular}




\begin{tabular}{|l|l|}
\hline Data / restraints / parameters & $8302 / 232 / 670$ \\
\hline Goodness-of-fit & 1.067 \\
\hline Final R indices [I>2sigma(I)] & $\mathrm{R} 1=0.0479, \mathrm{wR} 2=0.1100$ \\
\hline $\begin{array}{l}\text { Largest diff. peak and hole } \\
\left(e \cdot \AA^{-3}\right)\end{array}$ & 1.139 and -0.943 \\
\hline
\end{tabular}




\section{In-situ IR to investigate $\mathrm{N}=\mathrm{O}$ stretching frequency}

\section{IR of 1-BAr ${ }_{4}$ reacting with two equivalents of $\mathrm{PhCH}_{2} \mathrm{CH}_{2} \mathrm{SNO}$ and $\mathrm{PhCH}_{2} \mathrm{CH}_{2} \mathrm{~S}^{15} \mathrm{NO}$ in $\mathrm{THF}-d_{8}$}

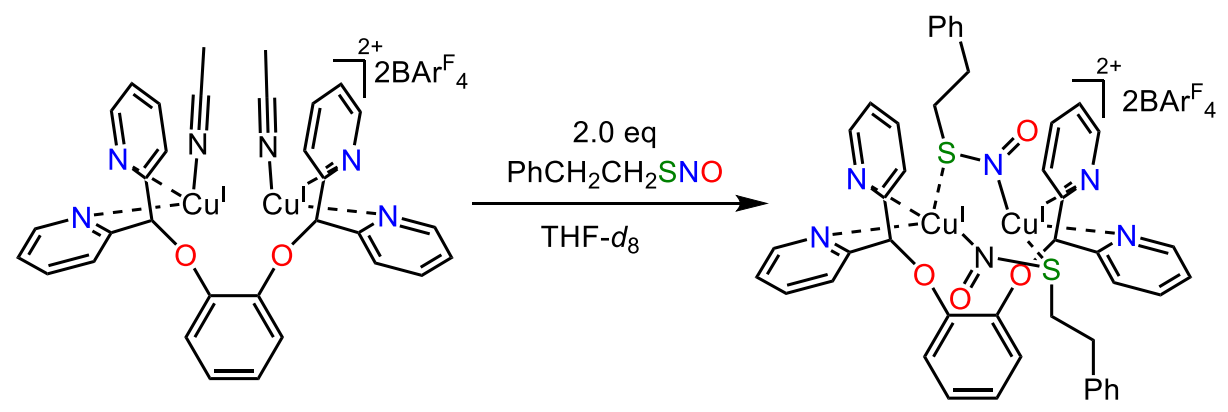

1-BAr ${ }_{4}{ }_{4}(57.6 \mathrm{mg}, \mathrm{MW}=2382.15 \mathrm{~g} / \mathrm{mol}, 24.2 \mu \mathrm{mol})$ was dissolved in THF- $d_{8}(1.1 \mathrm{~mL})$ to afford a $22 \mathrm{mM}$ solution. $\mathrm{PhCH}_{2} \mathrm{CH}_{2} \mathrm{SNO}(14.7 \mathrm{mg}, 87.9 \mu \mathrm{mol})$ was dissolved in THF- $d_{8}(0.20 \mathrm{~mL})$ to afford a $440 \mathrm{mM}$ solution. $\mathrm{PhCH}_{2} \mathrm{CH}_{2} \mathrm{~S}^{15} \mathrm{NO}(14.8 \mathrm{mg}, 87.9 \mu \mathrm{mol})$ was dissolved in THF- $d_{8}(0.20 \mathrm{~mL})$ to afford a $440 \mathrm{mM}$ solution. The 1-BAr${ }_{4}\left(1.0 \mathrm{~mL}, 22 \mathrm{mM}\right.$ solution in THF- $\left.d_{8}, 22 \mu \mathrm{mol}\right)$ solution was injected into a threeneck cell that had been connected to the react IR probe and purged with nitrogen for $c a .2 .5 \mathrm{~h}$. The cell was cooled in a dry ice/acetone bath $\left(-78{ }^{\circ} \mathrm{C}\right)$ for $c a .20 \mathrm{~min}$. After the temperature inside the cell stabilized, $\mathrm{PhCH}_{2} \mathrm{CH}_{2} \mathrm{SNO}$ or $\mathrm{PhCH}_{2} \mathrm{CH}_{2} \mathrm{~S}^{15} \mathrm{NO}\left(0.10 \mathrm{~mL}, 440 \mathrm{mM}\right.$ solution in THF- $d_{8}, 44 \mu \mathrm{mol}, 2.0$ equiv.) was injected into the cold solution dropwise, and the reaction progress was monitored for $c a .1 .5 \mathrm{~h}$ at this temperature. The IR spectra of $S$-nitrosothiol bound dicopper(I,I) complex synthesized from $\mathrm{PhCH}_{2} \mathrm{CH}_{2} \mathrm{SNO}$ (black trace) or $\mathrm{PhCH}_{2} \mathrm{CH}_{2} \mathrm{~S}^{15} \mathrm{NO}$ (red trace) are shown in Figure S62. Subtraction of the IR spectra of S-nitrosothiol-bound dicopper complex synthesized with $\mathrm{PhCH}_{2} \mathrm{CH}_{2} \mathrm{~S}^{15} \mathrm{NO}$ from that with $\mathrm{PhCH}_{2} \mathrm{CH}_{2} \mathrm{SNO}$ generates the ${ }^{14} \mathrm{~N} /{ }^{15} \mathrm{~N}$ differential spectrum in Figure S63. Based on this experiment, two $\mathrm{N}=\mathrm{O}$ stretches at $1512 \mathrm{~cm}^{-1}$ and $c a .1505 \mathrm{~cm}^{-1}$ are shifted to $1491 \mathrm{~cm}^{-1}$ and $1479 \mathrm{~cm}^{-1}$ respectively when $\mathrm{PhCH}_{2} \mathrm{CH}_{2} \mathrm{~S}^{15} \mathrm{NO}$ is used instead of $\mathrm{PhCH}_{2} \mathrm{CH}_{2} \mathrm{~S}^{14} \mathrm{NO}$ to bind to $1-\mathrm{BAr}_{4}$. These $\mathrm{N}=\mathrm{O}$ peaks can be assigned as symmetric and unsymmetric stretches of two $\mathrm{N}=\mathrm{O}$ motifs.

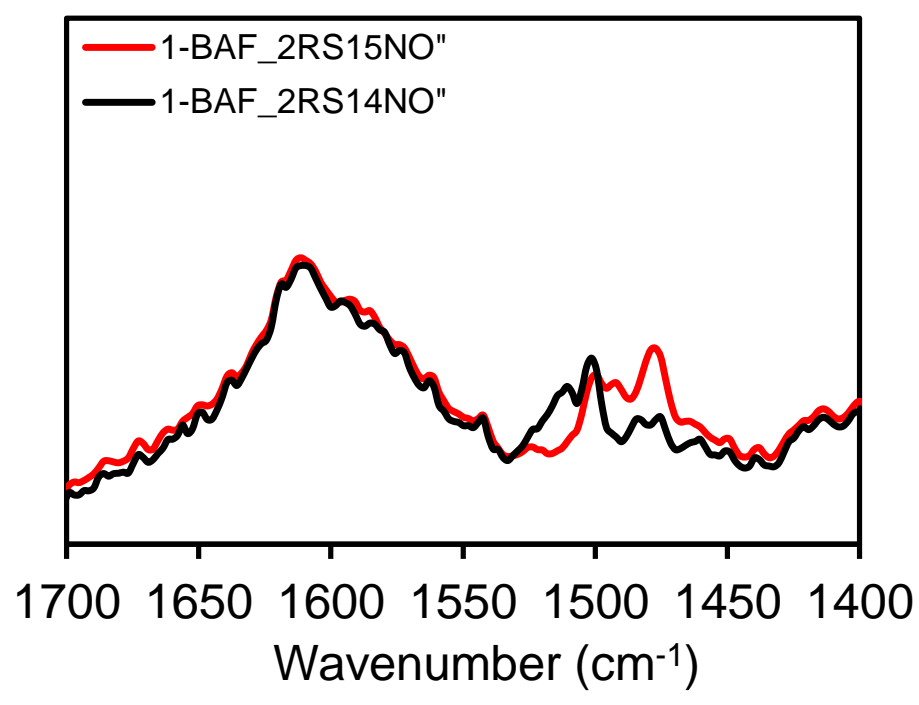

Figure S62. IR spectra of $S$-nitrosothiol-bound dicopper(I,I) complex from 1-B $\mathrm{Ar}^{\mathrm{F}} 4$ with $\mathrm{PhCH}_{2} \mathrm{CH}_{2} \mathrm{SNO}$ (black trace), or $\mathrm{PhCH}_{2} \mathrm{CH}_{2} \mathrm{~S}^{15} \mathrm{NO}$ (red trace) in THF- $d_{8}$ solvent in a dry ice/acetone bath. $v \mathrm{NO}_{14 \mathrm{~N}}=c a$. 
1512 and $1505 \mathrm{~cm}^{-1} ; v \mathrm{NO}_{15 \mathrm{~N}}=c a .1491$ and $1479 \mathrm{~cm}^{-1} \Delta v \mathrm{NO}_{14 \mathrm{~N}-15 \mathrm{~N}}=21$ and $26 \mathrm{~cm}^{-1} ; \Delta v \mathrm{NO}_{14 \mathrm{~N}-15 \mathrm{~N}}$ calculated from Hooke's Law is 27 and $27 \mathrm{~cm}^{-1}$.

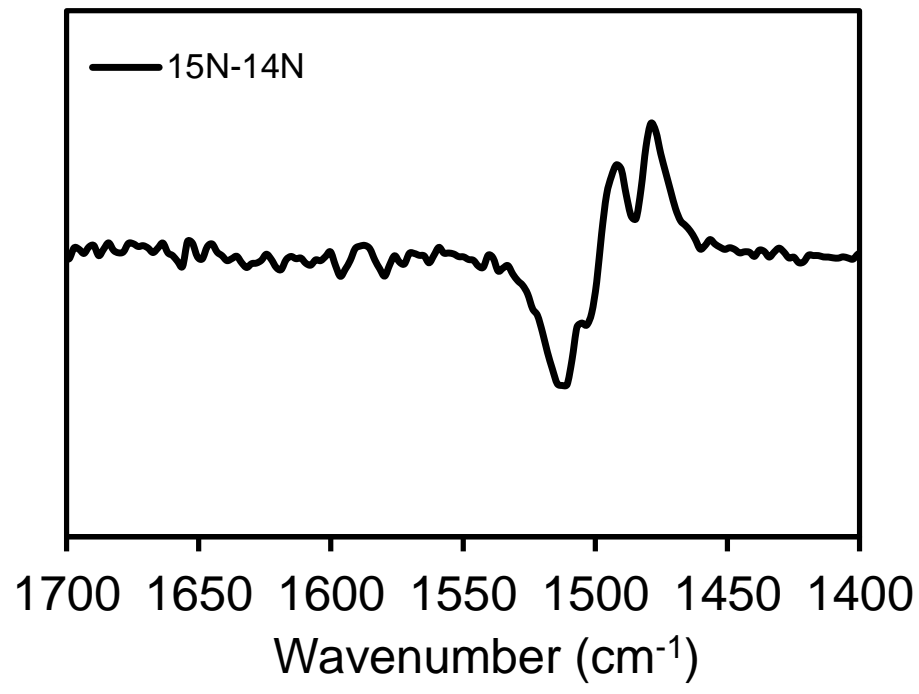

Figure S63. IR spectrum of S-nitrosothiol bound dicopper(I,I) complex synthesized with $\mathrm{PhCH}_{2} \mathrm{CH}_{2} \mathrm{~S}^{15} \mathrm{NO}$ subtracted from that with $\mathrm{PhCH}_{2} \mathrm{CH}_{2} \mathrm{SNO} . v \mathrm{NO}_{14 \mathrm{~N}}=1512$ and $1505 \mathrm{~cm}^{-1} ; v \mathrm{NO}_{15 \mathrm{~N}}=1491$ and $1479 \mathrm{~cm}^{-1}$ $\Delta v \mathrm{NO}_{14 \mathrm{~N}-15 \mathrm{~N}}=21$ and $26 \mathrm{~cm}^{-1} ; \Delta v \mathrm{NO}_{14 \mathrm{~N}-15 \mathrm{~N}}$ calculated from Hooke's Law is 27 and $27 \mathrm{~cm}^{-1}$. 
IR of free $\mathrm{PhCH}_{2} \mathrm{CH}_{2} \mathrm{SNO}$ and $\mathrm{PhCH}_{2} \mathrm{CH}_{2} \mathrm{~S}^{15} \mathrm{NO}$

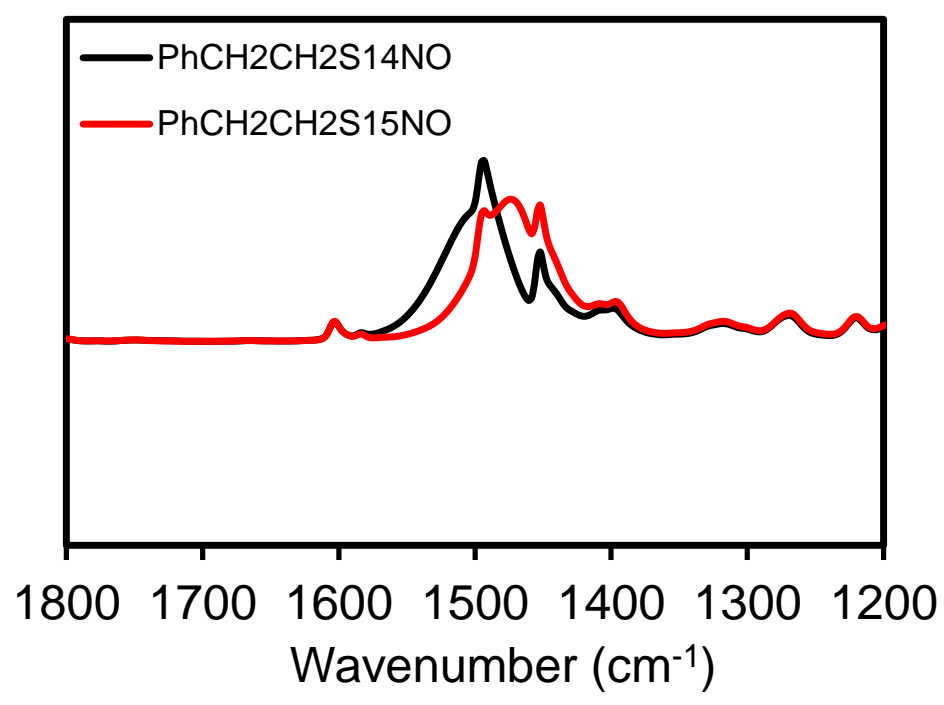

Figure S64. Infrared spectra of free $\mathrm{PhCH}_{2} \mathrm{CH}_{2} \mathrm{SNO}$ (black trace) and $\mathrm{PhCH}_{2} \mathrm{CH}_{2} \mathrm{~S}^{15} \mathrm{NO}$ (red trace). $v \mathrm{NO}_{14 \mathrm{~N}}=1495 ; v \mathrm{NO}_{15 \mathrm{~N}}=1468 \mathrm{~cm}^{-1} \Delta v \mathrm{NO}_{14 \mathrm{~N}-15 \mathrm{~N}}=27 \mathrm{~cm}^{-1} ; \Delta v \mathrm{NO}_{14 \mathrm{~N}-15 \mathrm{~N}}$ calculated from Hooke's Law is $27 \mathrm{~cm}^{-1}$.

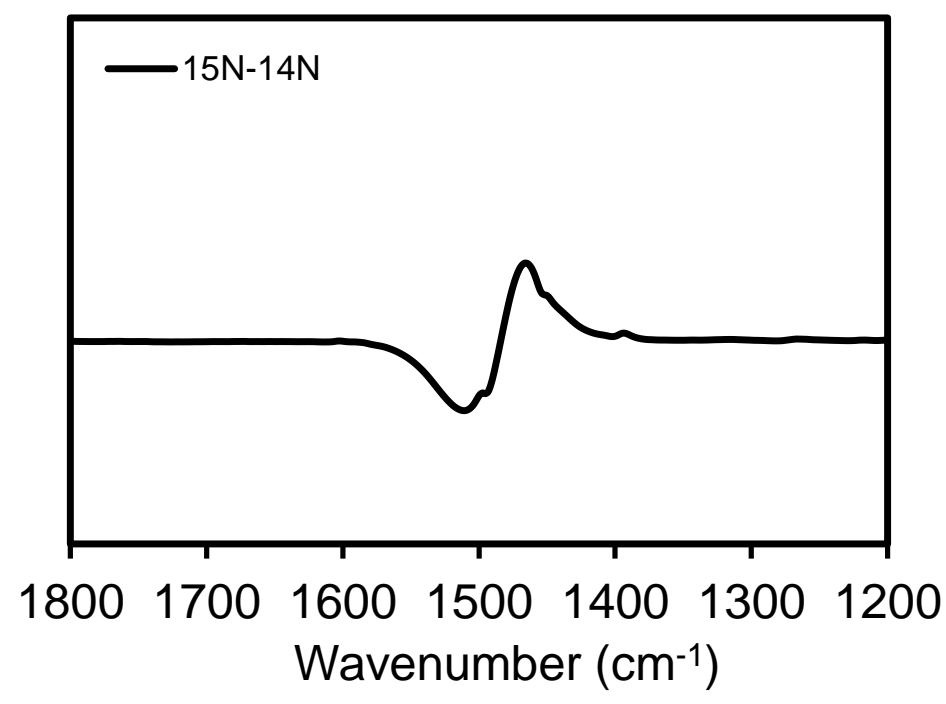

Figure S65. IR spectra of free $\mathrm{PhCH}_{2} \mathrm{CH}_{2} \mathrm{~S}^{15} \mathrm{NO}$ subtracted from that of $\mathrm{PhCH}_{2} \mathrm{CH}_{2} \mathrm{SNO}$. $v \mathrm{NO}_{14 \mathrm{~N}}=1495$ $\mathrm{cm}^{-1} ; v \mathrm{NO}_{15 \mathrm{~N}}=1468 \mathrm{~cm}^{-1} \Delta v \mathrm{NO}_{14 \mathrm{~N}-15 \mathrm{~N}}=27 \mathrm{~cm}^{-1} ; \Delta v \mathrm{NO}_{14 \mathrm{~N}-15 \mathrm{~N}}$ calculated from Hooke's Law is $27 \mathrm{~cm}^{-1}$. 


\section{IR of 1-OTf reacting with $\mathrm{NO}$ and ${ }^{15} \mathrm{NO}$ in the presence of methanol}

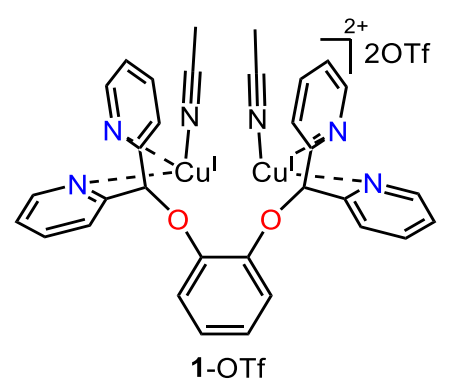

$$
\begin{aligned}
& { }^{14} \mathrm{NO} \text { or }{ }^{15} \mathrm{NO} \\
& \mathrm{DCM} / \mathrm{THF} \\
& \underset{\mathrm{MeOH}}{\mathrm{dry} \text { ice } / \mathrm{CH}_{3} \mathrm{CN}}
\end{aligned}
$$

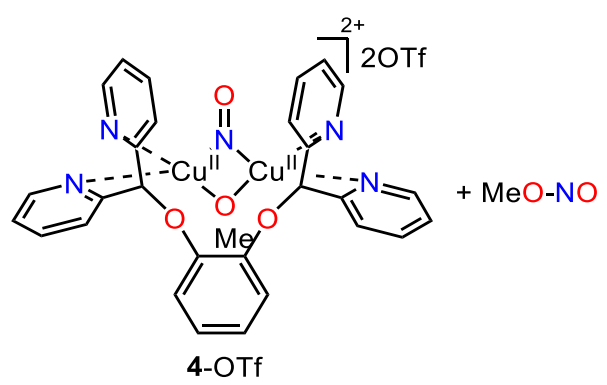

Complex 1-OTf $(15.7 \mathrm{mg}, 16.5 \mu \mathrm{mol})$ was dissolved in a mixture of dichloromethane $(0.50 \mathrm{~mL})$, THF $(0.40$ $\mathrm{mL})$, and methanol $(0.20 \mathrm{~mL})$ to afford a $15 \mathrm{mM}$ solution. The solution was injected into a three-neck cell that had been connected to the react IR probe and purged with nitrogen for $c a .1 .5 \mathrm{~h}$. The cell was cooled in a dry ice/acetonitrile bath $\left(-40^{\circ} \mathrm{C}\right)$ for $c a .20 \mathrm{~min}$. After the temperature inside the cell stabilized, NO• or ${ }^{15} \mathrm{NO} \cdot(4.0 \mathrm{~mL}, 167 \mu \mathrm{mol}, 10$ equiv. $)$ was injected into the cold solution and the reaction progress was monitored for $c a .2 .0 \mathrm{~h}$ at this temperature. The IR spectra of $\mathbf{4 b}$ synthesized from $\mathrm{NO} \bullet$ or ${ }^{15} \mathrm{NO} \bullet$ (Figure S66) are shown. The IR spectrum from reaction of 1-OTf and ${ }^{15} \mathrm{NO} \bullet$ subtracted from that of $\mathrm{NO} \bullet$ is shown in Figure $\mathrm{S} 67$. Based on the $\mathrm{N}=\mathrm{O}$ stretch at $1567 \mathrm{~cm}^{-1}$, the $\mu$-nitrosyl motif can be assigned as $\mathrm{NO}^{-}$.

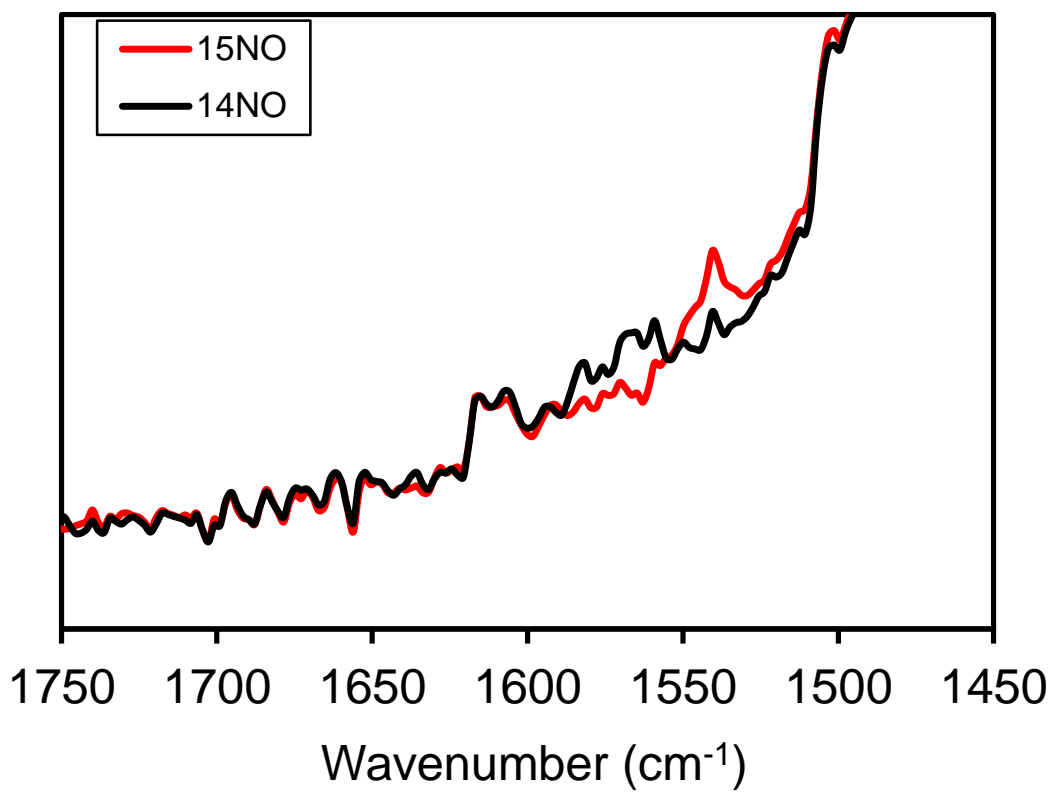

Figure S66. IR spectra of $\mathbf{4 b}$ synthesized from 1-OTf with ${ }^{14} \mathrm{NO} \bullet$ (black trace) and ${ }^{15} \mathrm{NO} \bullet$ (red trace) in a mixture of DCM, THF and methanol in a dry ice/acetonitrile bath. 


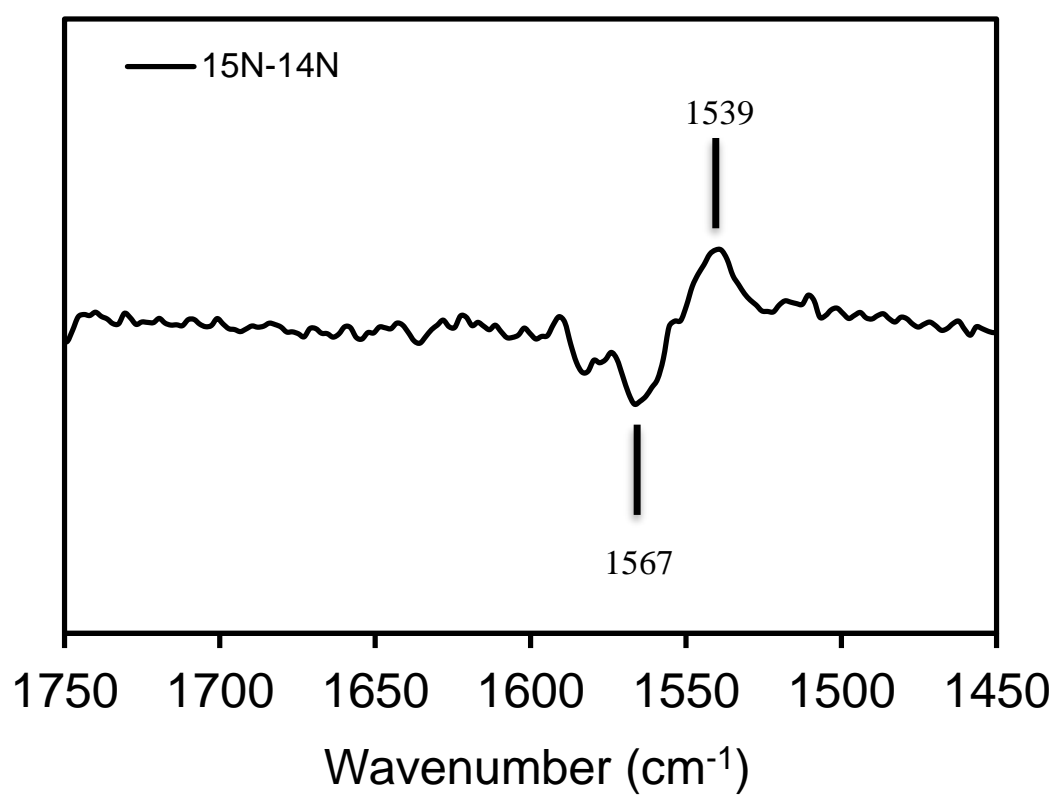

Figure S67. IR spectrum of $\mathbf{4 b}$ synthesized from 1-OTf with ${ }^{15} \mathrm{NO} \bullet$ (baseline adjusted) subtracted from that of ${ }^{14} \mathrm{NO} \bullet$ in a mixture of DCM, THF and methanol in a dry ice/acetonitrile bath. $v \mathrm{NO}_{14 \mathrm{~N}}=1567 \mathrm{~cm}^{-1}$; $v \mathrm{NO}_{15 \mathrm{~N}}=1539 \mathrm{~cm}^{-1} \Delta v \mathrm{NO}_{14 \mathrm{~N}-15 \mathrm{~N}}=28 \mathrm{~cm}^{-1} ; \Delta v \mathrm{NO}_{14 \mathrm{~N}-15 \mathrm{~N}}$ calculated with Hooke's Law is $28 \mathrm{~cm}^{-1}$. 


\section{X-band EPR details}

All samples were measured in $4 \mathrm{~mm}$ septum-capped EPR quartz tubes (Wilmad Lab glass, 727-SQ250MM).

4-OTf single crystal $(26.0 \mathrm{mg}, 26.9 \mu \mathrm{mol})$ was dissolved in cold acetone $(1.0 \mathrm{~mL})$ to make $26.9 \mathrm{mM}$ solution of 4-OTf and it was stored in the freezer of the glove box $\left(-40^{\circ} \mathrm{C}\right) .18 .6 \mu \mathrm{L}(0.500 \mu \mathrm{mol})$ of this $26.9 \mathrm{mM}$ cold 4-OTf solution was transferred into a precooled vial and diluted with $981 \mu \mathrm{L}$ of cold acetone to make $0.50 \mathrm{mM} \mathrm{4-OTf}$ in acetone. $0.20 \mathrm{~mL}$ of this $0.50 \mathrm{mM}$ solution was transferred into a precooled EPR tube inside the freezer of the glove box and the cold EPR tube with $0.50 \mathrm{mM}$ solution of 4-OTf was transferred quickly out of glove box and frozen in liquid nitrogen. To make a higher concentration sample for comparison, $112 \mu \mathrm{L}(3.0 \mu \mathrm{mol})$ of the $26.9 \mathrm{mM}$ cold 4-OTf solution was transferred into a precooled vial and diluted with $888 \mu \mathrm{L}$ of cold acetone to make $3.0 \mathrm{mM} \mathrm{4-OTf}$ in acetone. $0.20 \mathrm{~mL}$ of this $3.0 \mathrm{mM}$ solution was transferred into a precooled EPR tube inside the freezer of the glove box and the cold EPR tube with $3.0 \mathrm{mM}$ solution of 4-OTf was transferred quickly out of glove box and frozen in liquid nitrogen.

Spectra were collected at $20 \mathrm{~K}$ with a modulation frequency of $100 \mathrm{kHz}$ and a modulation amplitude of 5 $\mathrm{G}$ using $35 \mathrm{~dB}$ attenuation. A time constant of $40.96 \mathrm{~ms}$ and a conversion time of $70.59 \mathrm{~ms}$ were used. All spectra were baseline-corrected using Igor Pro (Wavemetrics, Lake Oswego, OR) software.

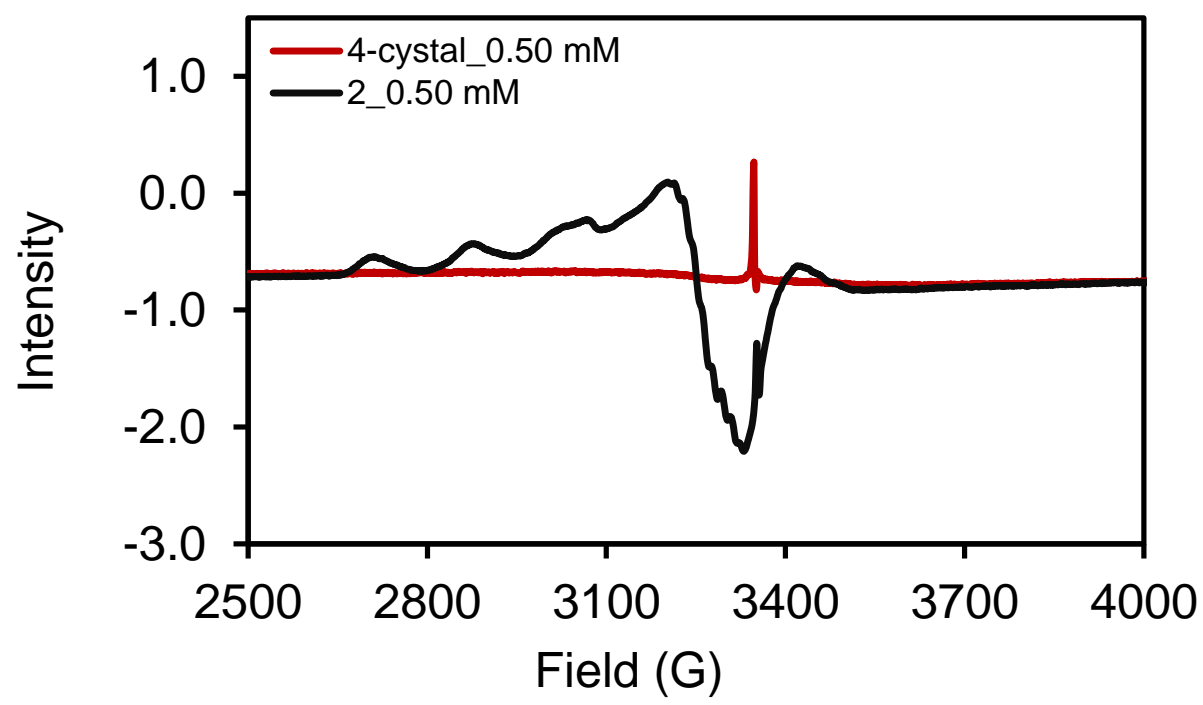

Figure S68. X-band EPR spectra $(20 \mathrm{~K})$ of 4-OTf at $0.50 \mathrm{mM}$ concentration (red trace, EPR silent) compared with $2-\mathrm{BAr}_{4}{ }_{4}$ at $0.50 \mathrm{mM}$ concentration (black trace) which has been characterized previously ${ }^{[8]}$. 


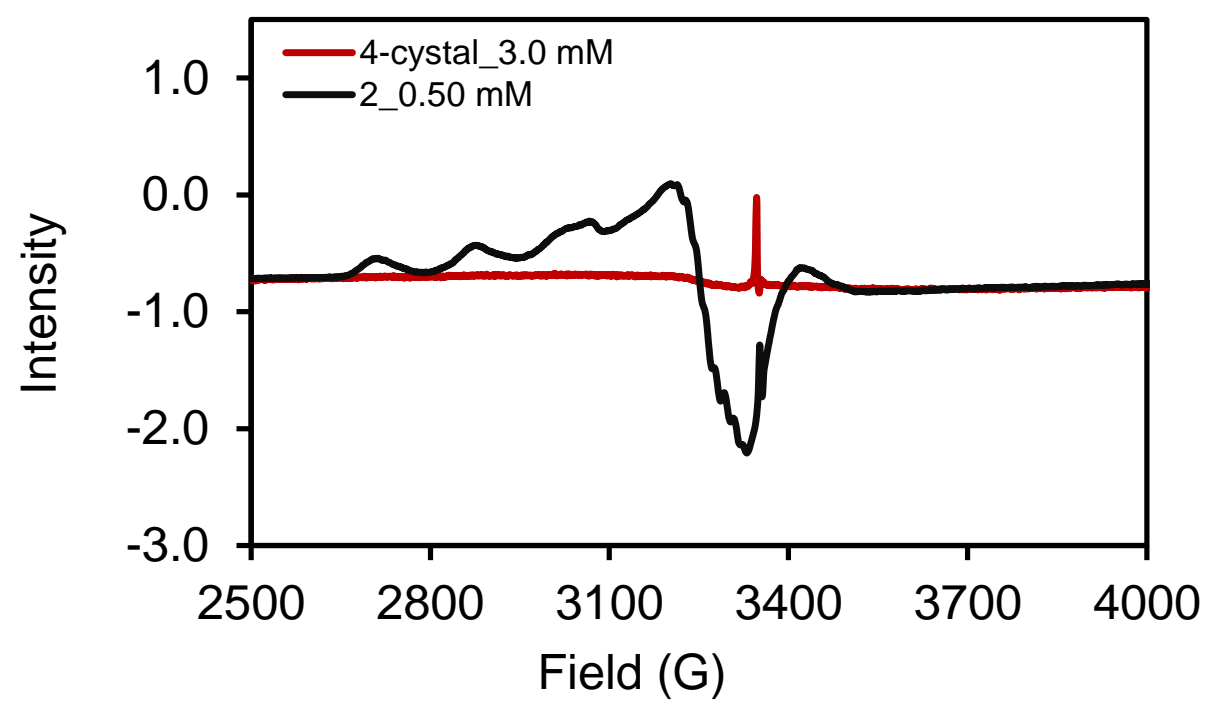

Figure S69. X-band EPR spectra (20 K)of 4-OTf at $3.0 \mathrm{mM}$ concentration (red trace, EPR silent) compared with $2-\mathrm{BAr}_{4}{ }_{4}$ at $0.50 \mathrm{mM}$ concentration (black trace) which has been characterized previously. ${ }^{[8]}$

4-OTf is EPR silent regardless of its concentration. Combining X-ray single-crystal structure, EPR, and in-situ IR investigation of NO stretch, 4-OTf is assigned as dicopper(II,II) $\mu$-methoxo, $\mu$-NO ${ }^{-}$complex. 


\section{Computational details}

All computations were performed in parallel on 16 processors using Gaussian or $\mathrm{ORCA}^{[9]}$ programs and the structures were visualized in the ChemCraft program. DFT geometry optimizations of $\left[\mathbf{L C u}_{2}{ }_{2}(\mu-\right.$ $\mathrm{NO})(\mu-\mathrm{OMe})]^{2+}$ and $\left[\mathrm{LCu}_{2}{ }_{2}(\mu-\mathrm{NO})(\mu-\mathrm{SMe})\right]^{2+}$ were performed using B3LYP ${ }^{[10]}-\mathrm{D} 3^{[11]}$ method with def2TZVP basis set ${ }^{[12]}$. Energy minima were confirmed by a vibrational frequency calculation, and no imaginary frequencies were observed. All DFT calculations were performed using very tight convergence thresholds for the energy $\left(10^{-9} \mathrm{E}_{\mathrm{h}}\right)$.

Optimized coordinates of complex $4\left(\left[\mathbf{L C u}_{2}{ }_{2}(\mu-\mathrm{NO})(\mu-\mathrm{OMe})\right]^{2+}\right)$

$\begin{array}{lccc}29 & 5.343695309 & 6.352154954 & 2.711849168 \\ 29 & 4.581257898 & 3.617051960 & 1.575585422 \\ 8 & 7.109214289 & 3.267808374 & 1.250803129 \\ 8 & 7.776400859 & 5.650135980 & 2.245113453 \\ 8 & 4.215371455 & 5.522569602 & 1.349775261 \\ 7 & 4.568312021 & 4.561897350 & 3.424560745 \\ 7 & 4.813671747 & 2.817424977 & -0.314182973 \\ 7 & 6.255970798 & 7.982917043 & 1.833097285 \\ 7 & 5.012562820 & 1.852927668 & 2.439985558 \\ 7 & 6.345201459 & 6.643244352 & 4.431541954 \\ 8 & 3.591888428 & 4.574120313 & 4.049488633 \\ 6 & 8.018717841 & 4.021358576 & 0.522744363 \\ 6 & 2.853083274 & 5.928761930 & 1.287106895 \\ 1 & 2.313738006 & 5.694756576 & 2.215445644 \\ 1 & 2.353763200 & 5.418341104 & 0.460474008 \\ 1 & 2.797102459 & 7.006523475 & 1.118349498 \\ 6 & 6.104720404 & 1.243967715 & 1.943739527 \\ 6 & 8.173115517 & 6.892786615 & 2.850175709 \\ 1 & 9.259852384 & 6.980906904 & 2.866910009 \\ 6 & 5.865184300 & 1.988944420 & -0.422850308 \\ 6 & 6.792797462 & 1.943341819 & 0.788924082 \\ 1 & 7.702983812 & 1.396873645 & 0.539974550 \\ 6 & 7.565675122 & 8.083853846 & 2.113012968 \\ 6 & 7.665347774 & 6.851405801 & 4.277338804 \\ 6 & 8.371075275 & 5.279080745 & 1.047766339 \\ 6 & 6.073559272 & 1.216245749 & -1.554020740 \\ 1 & 6.926421703 & 0.551949926 & -1.612400093 \\ 6 & 4.327315203 & 1.276799888 & 3.435653057 \\ 1 & 3.461371918 & 1.814708731 & 3.800155638 \\ 6 & 8.302276888 & 9.206409345 & 1.770519896 \\ 1 & 9.355582665 & 9.263931388 & 2.014031120 \\ 6 & 8.603110979 & 3.593677973 & -0.662870965 \\ 1 & 8.349864475 & 2.634818831 & -1.085072409 \\ 6 & 9.295261909 & 6.062623084 & 0.368021980 \\ 1 & 9.582113867 & 7.028930427 & 0.749804225 \\ 6 & 6.543837876 & 0.027531240 & 2.441106636 \\ 1 & 7.430755456 & -0.438499183 & 2.032852997 \\ 6 & 5.647863587 & 8.978049147 & 1.176292496\end{array}$




$\begin{array}{lccc}1 & 4.595884738 & 8.841220791 & 0.963718942 \\ 6 & 7.667540843 & 10.249072679 & 1.102392798 \\ 1 & 8.220413485 & 11.136517425 & 0.822493366 \\ 6 & 3.957875769 & 2.927463809 & -1.337381713 \\ 1 & 3.135745243 & 3.618059360 & -1.204137718 \\ 6 & 8.497887311 & 7.054781265 & 5.366125386 \\ 1 & 9.558261467 & 7.210217662 & 5.218113525 \\ 6 & 5.175403153 & 1.317251562 & -2.612118365 \\ 1 & 5.316010660 & 0.725612908 & -3.507531891 \\ 6 & 5.827323679 & -0.579777839 & 3.468277978 \\ 1 & 6.149299565 & -1.531906661 & 3.869934178 \\ 6 & 4.699751241 & 0.054228991 & 3.973987724 \\ 1 & 4.114641444 & -0.385366165 & 4.769976909 \\ 6 & 9.528798360 & 4.387843550 & -1.334850907 \\ 1 & 9.970469271 & 4.029791364 & -2.254901322 \\ 6 & 6.319676277 & 10.128650617 & 0.789262453 \\ 1 & 5.792147733 & 10.911262651 & 0.261576735 \\ 6 & 9.875022629 & 5.622648661 & -0.819189178 \\ 1 & 10.593566327 & 6.251639588 & -1.326963208 \\ 6 & 4.105184766 & 2.196431676 & -2.507378868 \\ 1 & 3.391034858 & 2.312320054 & -3.310982311 \\ 6 & 5.815127572 & 6.632544705 & 5.661100585 \\ 1 & 4.749356433 & 6.453609239 & 5.725759377 \\ 6 & 7.948398440 & 7.055870841 & 6.644914118 \\ 1 & 8.578711992 & 7.216548210 & 7.510032241 \\ 6 & 6.584337663 & 6.842103182 & 6.795812291 \\ 1 & 6.118547964 & 6.837585543 & 7.771627733\end{array}$

Optimized coordinates of complex $7\left[\mathbf{L C u}{ }_{2}(\mu-\mathrm{NO})(\mu-\mathrm{SMe})\right]^{2+}$

$\begin{array}{lccc}29 & 7.294576189 & 7.821402198 & 3.965351001 \\ 29 & 6.397457501 & 4.989309306 & 2.749806602 \\ 8 & 8.917800465 & 4.506521761 & 2.743537757 \\ 8 & 9.661497704 & 6.853047467 & 3.754590154 \\ 16 & 5.904705480 & 7.179666619 & 2.248235710 \\ 7 & 6.434552455 & 6.015172606 & 4.567609930 \\ 7 & 6.795045196 & 4.032809945 & 0.969672519 \\ 7 & 8.479434901 & 9.348458299 & 3.253715542 \\ 7 & 6.661784394 & 3.258723623 & 3.795130968 \\ 7 & 8.145623330 & 7.955934506 & 5.813161520 \\ 8 & 5.488658706 & 6.022360421 & 5.248553912 \\ 6 & 9.942095210 & 5.174479009 & 2.089143031 \\ 6 & 4.189803441 & 7.468628883 & 2.843911849 \\ 1 & 4.051121102 & 7.077883609 & 3.854358126 \\ 1 & 3.499375285 & 6.971919834 & 2.165913114 \\ 1 & 3.997909472 & 8.539263363 & 2.840348015 \\ 6 & 7.767480306 & 2.572195715 & 3.456448665 \\ 6 & 10.140912342 & 8.028362150 & 4.431222982 \\ 1 & 11.223927611 & 7.983842256 & 4.552175491 \\ 6 & 7.806005362 & 3.151649253 & 1.034755664\end{array}$




$\begin{array}{cccc}6 & 8.601392317 & 3.163384462 & 2.337373401 \\ 1 & 9.512448582 & 2.574871510 & 2.222703675 \\ 6 & 9.752255730 & 9.297824714 & 3.678202995 \\ 6 & 9.488882573 & 8.019868537 & 5.799456358 \\ 6 & 10.335755140 & 6.415729885 & 2.624183072 \\ 6 & 8.083510621 & 2.279660959 & -0.005718271 \\ 1 & 8.901946632 & 1.575536733 & 0.074917082 \\ 6 & 5.855614976 & 2.783999771 & 4.751687490 \\ 1 & 4.987908727 & 3.384927634 & 4.992884300 \\ 6 & 10.636662893 & 10.342492466 & 3.462656782 \\ 1 & 11.656590497 & 10.277579933 & 3.819980205 \\ 6 & 10.594674001 & 4.681557519 & 0.966180129 \\ 1 & 10.308146270 & 3.735059587 & 0.536952498 \\ 6 & 11.368429407 & 7.119634318 & 2.017550969 \\ 1 & 11.685224860 & 8.073256595 & 2.407952802 \\ 6 & 8.096446624 & 1.376324333 & 4.074132661 \\ 1 & 8.996388684 & 0.846761774 & 3.790940651 \\ 6 & 8.055320079 & 10.420659513 & 2.573812193 \\ 1 & 7.026228131 & 10.398718184 & 2.240136536 \\ 6 & 10.192817592 & 11.466449226 & 2.772237637 \\ 1 & 10.863564466 & 12.296071515 & 2.589417227 \\ 6 & 6.051182430 & 4.099230077 & -0.141168584 \\ 1 & 5.262793691 & 4.840366294 & -0.144909012 \\ 6 & 10.222792784 & 8.110309533 & 6.971220896 \\ 1 & 11.303338965 & 8.150931825 & 6.935105131 \\ 6 & 7.299656979 & 2.333881471 & -1.154479492 \\ 1 & 7.495752128 & 1.664660733 & -1.982300277 \\ 6 & 7.252047854 & 0.872564668 & 5.059432530 \\ 1 & 7.485596846 & -0.061860776 & 5.553271831 \\ 6 & 6.112345266 & 1.587290347 & 5.404623719 \\ 1 & 5.430815982 & 1.229655820 & 6.164101023 \\ 6 & 11.630251228 & 5.395224896 & 0.368018691 \\ 1 & 12.124128651 & 4.988336958 & -0.503945290 \\ 6 & 8.883300860 & 11.502171231 & 2.309905259 \\ 1 & 8.503988884 & 12.351743661 & 1.758946159 \\ 6 & 12.017096308 & 6.614024348 & 0.893659647 \\ 1 & 12.820018588 & 7.180333806 & 0.441546808 \\ 6 & 6.273024275 & 3.266818950 & -1.228722616 \\ 1 & 5.649622572 & 3.348826078 & -2.108411592 \\ 6 & 7.494408335 & 7.977936797 & 6.981804336 \\ 1 & 6.414963002 & 7.909686267 & 6.933459496 \\ 6 & 9.547430585 & 8.147970443 & 8.187811087 \\ 1 & 10.098702254 & 8.222723767 & 9.116295698 \\ 6 & 8.160208090 & 8.081065399 & 8.194414425 \\ 1 & 7.598627148 & 8.108265586 & 9.118036056\end{array}$




\section{References}

[1] M. Brookhart, B. Grant, A. F. Volpe, Organometallics 1992, 11, 3920-3922.

[2] G. Roelfes, V. Vrajmasu, K. Chen, R. Y. N. Ho, J.-U. Rohde, C. Zondervan, R. M. la Crois, E. P. Schudde, M. Lutz, A. L. Spek, et al., Inorg. Chem. 2003, 42, 2639-2653.

[3] O. Rivada-Wheelaghan, S. L. Aristizábal, J. López-Serrano, R. R. Fayzullin, J. R. Khusnutdinova, Angew. Chemie 2017, 129, 16485-16489.

[4] C. E. Aroyan, S. J. Miller, J. Am. Chem. Soc. 2007, 129, 256-257.

[5] N. Arulsamy, D. S. Bohle, J. A. Butt, G. J. Irvine, P. A. Jordan, E. Sagan, J. Am. Chem. Soc. 1999, $121,7115-7123$.

[6] M. M. Melzer, S. Mossin, A. J. P. Cardenas, K. D. Williams, S. Zhang, K. Meyer, T. H. Warren, Inorg. Chem. 2012, 51, 8658-8660.

[7] C. M. Park, T. D. Biggs, M. Xian, J. Antibiot. (Tokyo). 2016, 69, 313-318.

[8] W. Tao, J. K. Bower, C. E. Moore, S. Zhang, J. Am. Chem. Soc. 2019, 141, 10159-10164.

[9] F. Neese, F. Wennmohs, U. Becker, C. Riplinger, J. Chem. Phys. 2020, 152, 224108.

[10] P. J. Stephens, F. J. Devlin, C. F. Chabalowski, M. J. Frisch, J. Phys. Chem. 1994, 98, 1162311627.

[11] S. Grimme, J. Antony, S. Ehrlich, H. Krieg, J. Chem. Phys. 2010, 132, DOI 10.1063/1.3382344.

[12] A. Schäfer, H. Horn, R. Ahlrichs, J. Chem. Phys. 1992, 97, 2571-2577. 